\title{
Changes in numbers and distribution of wintering waterfowl in Sweden during forty years, 1967-2006
}

\author{
Förändringar $i$ antal och utbredning hos övervintrande sjöfåglar $i$ Sverige under \\ fyrtio år 1967-2006
}

LEIF NILSSON

\begin{abstract}
Regular midwinter counts of waterfowl (included in the International Midwinter Counts, IWC, organized by what is now Wetlands International) has been undertaken in Sweden since the start in 1967 and are still going on, now as a part of the National Environmental Monitoring Programme. After the first exploratory years including country-wide surveys in 1971-1973 undertaken both from the ground, the air and boats, the programme was standardized to cover an adequate sample of coastal and inland sites of south Sweden for the production of annual midwinter population indices for important species (areas further north in Sweden are normally ice-covered and without importance for waterbirds in winter). Further large scale surveys were undertaken in 1987-1989, 1993 and 2004 (country-wide survey). The programme did not cover the seaducks in offshore areas (later included in a special programme). The present contribution analyses the first 40 years of midwinter counts in Sweden, especially with the aim to elucidate changes in distribution and numbers of the different species during this time series. During the period there was a marked change in the winter weather and especially the ice situation in Sweden in January, being a factor of importance for the wintering waterbirds. During the years 1967-1987 there were

showed a marked increase from 172,000 to 627,000 individuals excluding the offshore species Clangula hyemalis and Melanitta spp. Anas platyrhynchos increased from 67,000 to 150,000 , Aythya fuligula from 54,000 to 230,000 and Bucephala clangula from 19,000 to 75,000. Increases were also found in most of the other species. In addition, Anas penelope and Podiceps cristatus established new wintering traditions in south Sweden. Midwinter indices for nine out of ten species showed significantly increasing trends over the 40 years, no species decreasing. In Anas platyrhynchos and Aythya fuligula the indices showed fluctuations around a steady level, then a marked increase followed after the last cold winter, whereas species like Bucephala clangula and Mergus serrator showed increasing trends from the start of the counts. Fulica atra crashed markedly after one cold winter and remained for years on a low level before recovering but the overall trend was increasing. To a large extent the increases found are probably due to the milder winters in later years, which also led to changes in winter distribution within the country, also being reflected in the regional totals for different species. Part of the increases does also reflect genuine population increases as show by comparisons with IWC results from other countries.
\end{abstract} five really hard ice-winters, whereas in the latter part of the period there was no really hard ice-winter. Comparisons between the country-wide surveys in 1971 and 2004
Leif Nilsson, Department of Ecology, Ecology Building, SE-22362 Lund, Sweden. leif.nilsson@zooekol.lu.se

Received 10 January 2008, Accepted 1 November 2008, Editor: S. Svensson

\section{Introduction}

In the years after the Second World War there was a general feeling in some European countries that the population levels of many species of waterbirds and geese were very low and that action was needed to protect these populations and their habitats. It was also early realised that it was necessary to monitor the waterfowl populations to get necessary information on which to base management actions. Thus, the National Wildfowl Counts were started in Britain in 1947, being organized by the Wildfowl
Trust since 1954 (Atkinson-Willes 1963). This programme is still going on in Britain, under the name Wetland Bird Survey - WEBS Banks et al. 2006), nowadays also including waders.

Regular counts of staging and wintering waterbirds, often on a monthly basis from early autumn to spring as in Britain, started in a number of other European countries during the late fifties and the sixties (cf. Atkinson-Willes 1963 and Owen et al. 1986 and references to other countries in these papers). In Sweden, monthly waterbird counts during September-April started on a small scale in 
$1959 / 1960$, ending in 1974/1975 (Nilsson 1968, 1976). It was soon realised that international cooperation was needed as waterbirds are migratory and thus it was going to be difficult to interpret data collected in one country only. This lead to the formation of the International Waterfowl Research $\mathrm{Bu}$ reau (IWRB, now Wetlands International), which since then is coordinating counting dates etc. in the participating countries.

The first years of waterbird counting in the different countries produced a lot of interesting results (cf. Atkinson-Willes 1963, Nilsson 1968, 1976, Owen et al. 1986), but in the mid-sixties it was realised that a more coordinated international project was needed to reach the goals. This led to the organization of the first International Midwinter Count of waterfowl in January 1967 (AtkinsonWilles 1969). Sweden has taken part since the start of the counts (Nilsson 1975).

January was chosen for the census as the waterfowl are generally most concentrated during the winter, most of them in addition staying in the more densely populated regions of Europe, where the chances to recruit enough counters were relatively good.

From the start the goal was set to make full cover counts of the wintering waterbirds over as large areas as possible on an annual basis. The main aims from the start were as follows:

- To establish the distribution of wintering waterfowl on an international basis.

- To estimate the total numbers of the different waterfowl populations on an international level.

- To form a basis to follow the long-term changes and trends in the waterfowl populations

- To establish the importance of different wetland areas for the staging and wintering waterfowl populations.

- To give advice to authorities on different levels in questions concerning the management of waterfowl and wetlands.

The International Midwinter Counts were a success from the start, and the counts got a wide coverage already early and nowadays they are undertaken in a large number of countries especially in Europe and neighbouring parts of west Asia and north Africa, but also in other countries in Asia and Africa, whereas North America has its own programme for waterfowl monitoring (Gillisen et al. 2002; se also the homepage of Wetlands International under the address: www.wetlands.org).

Already in the first years, the results from the midwinter counts were used in international con- servation work. When the Ramsaar Convention on wetlands was established in 1971, they were used to establish criteria for selection of wetlands of international importance, i. e. the $1 \%$ criterion meaning that wetlands which regularly were used by $1 \%$ (or 20,000 individuals) of the population of a species/ population should be considered as internationally important (Matthews 1993). Nowadays the counts together with information from other sources (e.g. the international wader counts) are used to produce regular population estimates for the wetland birds of which the fourth edition has now been published (Delany \& Scott 2006).

During the first years of the International Midwinter Counts (IMC) the aim was to obtain as good coverage as possible of all wetland areas of potential importance for wintering waterbirds. In many countries (e.g. Britain, the Netherlands, Germany) it was possible to obtain more or less complete coverage of lakes and rivers and of inshore coastal waters through chains of voluntary observers, whereas it was impossible to cover all important areas from the ground in other countries such as Sweden with archipelagos and Denmark with large areas of shallow open water. The solution to this dilemma was aerial surveys that were used in Denmark from the 1968 (Joensen 1968, 1974) and in Sweden from 1971 being complemented by counts from the Swedish Coastguard patrol vessels.

After the first years with country-wide surveys in 1971-1973 (Nilsson 1975), when more or less complete coverage of important areas was attained in Swedish inshore waters, it was clear that it was not possible to cover all sites of importance every year. The midwinter counts in Sweden and most other countries therefore concentrated on obtaining sufficient data for the calculation of annual population indices. According to the international programme, country-wide surveys were to be organized at intervals. These large scale surveys were organized in Sweden and some countries during 1987-1989 (Nilsson 1991) 1993, and in 2004. The offshore areas were not included, as it was not possible to cover the entire Baltic Sea with aerial and boat surveys before the 1990s, when the first total waterbird survey of the Baltic region was organized in 1992-1993 (Durinck et al. 1994).

The International Midwinter Counts originally covered ducks and swans. The Coot was included in the counts from 1968. In Sweden, divers, grebes, Heron and Cormorant were included in the programme in 1971 . Geese are covered by a special program which includes a midwinter count but also additional counts in other months of the year. The 
results of the goose counts in Sweden will be covered in another paper.

In the present contribution I will analyse the first forty years of midwinter counts of waterbirds in Sweden. The main emphasis will be on the changes in numbers and distribution and especially whether there are any significant long term trends. The analysis will be undertaken against the background of the international results available at the headquarters of Wetlands International and published regularly in their reports (cf. Delany et al. 1999, Gilissen et al 2002 and on their homepage www. wetlands.org. The sea ducks are included, but I only present data obtained during the surveys of coastal and inshore waters as there are no complete survey data available from offshore areas yet (although see Durinck et al. 1994).

The International Midwinter Counts of Waterbirds in Sweden are included in the National Monitoring Program for Birds organized by the Swedish Environmental Protection Agency .

\section{Material and methods}

\section{Organization}

The International Midwinter Counts of Waterbirds in Sweden as in the other countries rely on voluntary counters, which cover one or more counting units at the specified dates. Volunteers were originally recruited by directly contacting large numbers of bird watchers and other people that could be interested but also via local bird clubs, bird magazines etc. In this way a network of observers was built up, some sites being covered by one or a few observers, whereas bird clubs or other groups of counters together covered other areas.

During the first years of midwinter counts, the observers freely selected the sites to be covered but from the 1980s the counts for index calculations were standardized and a representative selection of larger coastal and inland areas (reference areas here) was covered each year. These areas were built up of a number of smaller counting units, which were counted separately. In addition to the reference areas, counts from smaller sites spread over the country were also collected for the index calculations.

During 1971-1973, large scale aerial surveys (cf. Nilsson 1975) were performed in addition to extensive ground counts to obtain full coverage of inland sites and inshore coastal areas. Moreover several boat patrols were undertaken from the ships of the Swedish Coast Guard. Aerial surveys and boat counts were continued in a smaller scale during
January 1974-1977. Large scale surveys, including aerial surveys, were also organized in 1987-1989, 1993 and in 2004.

The International Midwinter Counts were organized on the weekend with the Sunday closest to 15 January. The weeks before and after were used as alternative periods in case of bad weather during the main counting weekend and to cover additional sites. During country-wide surveys the entire month of January and sometimes even the first weeks of February had to be used to be able to cover all areas.

As the Whooper Swans Cygnus cygnus were found to change habitat during the study period, from being fully aquatic as the other waterbirds treated here to become more and more terrestrial like the geese, the IMC was found to be less suitable to monitor Whooper Swans (and Bewick's Swans Cygnus bewickii). Accordingly three special surveys were organized in 1995, 2000 and 2005 (see Nilsson 1997, 2002 for the first two surveys, but results from the Swedish surveys will be integrated in this report also).

\section{Study areas and counting units}

After the first few exploratory years, the entire Swedish coast was divided into counting units with established borders that have been kept the same through the years. The strategy has been to have borders for the counting units in such a way that they can be easily recognized in the field. The size of the counting units was chosen so that it was always possible to cover the entire unit during one day. In practice it was normally possible for the counters to cover a number of counting units in a day. The counting units were then grouped into larger reference areas that can be seen as a functional unit for the waterbirds.

This system of counting units and reference areas covers the entire coastal waters with the exception of the offshore banks in the Baltic and the west coast, but includes both the inner (counted from the shore) and outer areas along the open coasts and the islets in the outer archipelago zone and the waters close to these areas.

For inland Sweden, smaller lakes form one counting unit, whereas the larger lakes were split into several counting units in the same way as the coastal areas. Rivers were in many cases also split into smaller counting units. Many of them were quite small being formed by the open water areas close to rapidly streaming water often separated by larger stretches of river from the next open water area. 
For the analyses of geographical differences of waterbird trends the coast from the Norwegian border to the province of Uppland (i.e. the part of the Swedish coast that normally had ice-free areas during normal winters when the counts started) was divided into fourteen regions with similar character (Figure 1). When counts started the areas north of the county of Stockholm (region O) were normally ice covered and were therefore not extensively covered by the counts. These areas are not included in the index counts but have been covered in the most

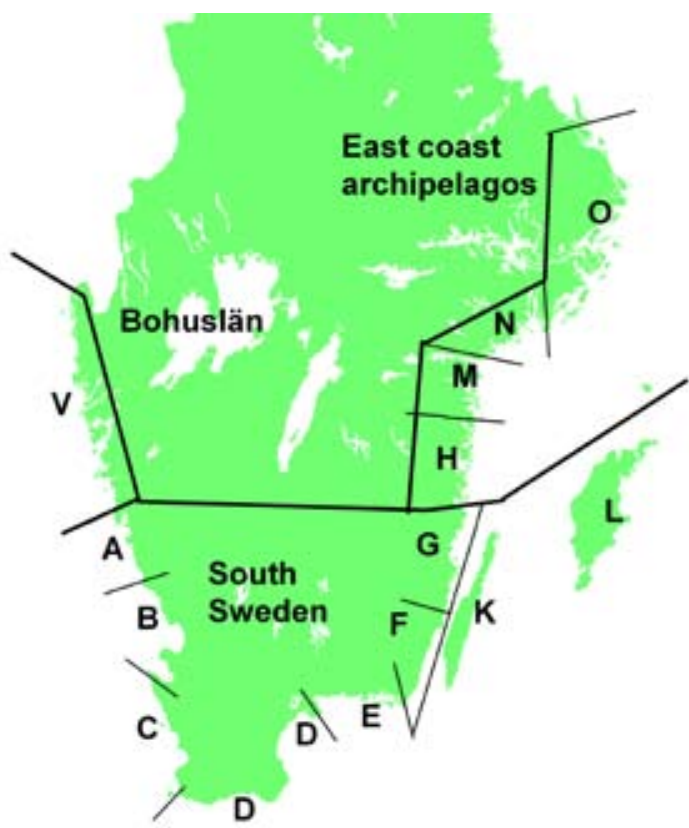

Figure 1. The division of the Swedish coast into regions (A$\mathrm{O}, \mathrm{V})$ and three larger areas used in the analysis of countrywide surveys. For description of the regions, see text! Indelning av den svenska kusten i regioner $(A-O, V)$ och tre större områden utnyttjade för analys av de landsomfattande inventeringarna. För beskrivning av regionerna se texten! recent years when open water was available, e.g. with partial surveys at the country wide survey in 2004. The counting units and reference areas that were used for index calculations are shown in Figure 2 and 3.

The Swedish coast varies from marine with full salinity in the archipelagos of Bohuslän (V) to very brackish in the Baltic. The outermost smaller islands both on the west coast and in the Baltic are quite barren but in the inner bays there are extensive areas with Zostera-meadows and shallow water, the

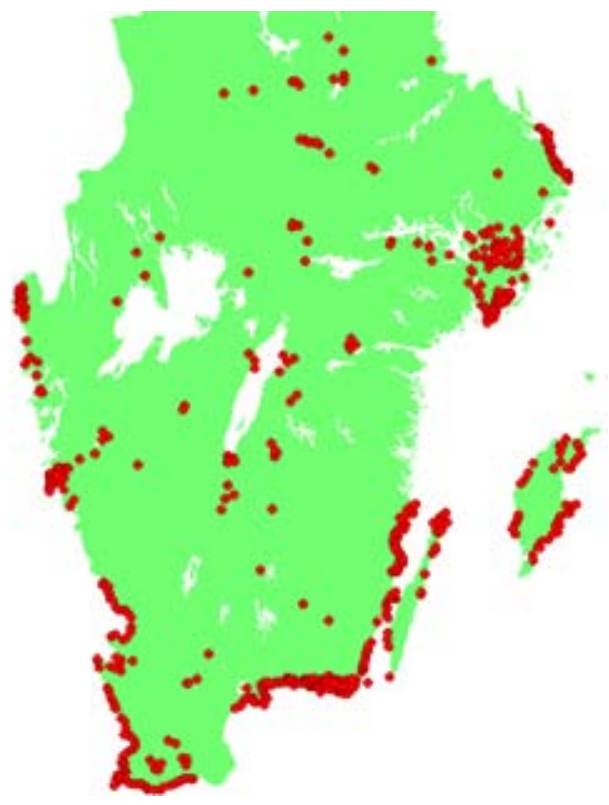

Figure 2. The geographical distribution of the counting units that were included in the index calculations together with the reference areas shown in Figure 3. These counting units were covered almost annually during at least 1987-2006 (in most cases since the first years of the project). For details on units covered in individual years see information in published reports (listed in the appendix).

Den geografiska fördelningen av standardlokaler som ingår $i$ indexberäkningarna tillsammans med referensområdena $i$ Figur 3. Dessa lokaler har täckts årligen åtminstone under 1987-2006 (men i flertalet fall sedan projektets första år). För detaljer $i$ täckningen olika år se de årliga rapporterna från projektet (se appendix). 
vegetation of shallow water areas gradually changing to other species in the Baltic. The Kategatt (A, B) is also relatively saline but is influenced by the outflow of water with low salinity from the Baltic. In the northern part there are some islands but the southern part is open. The shoreline varies between sandy beaches and moraine shores. The water close to land is relatively shallow.

The Öresund between Sweden and Denmark, $\mathrm{C}$, is a transition area between the North Sea (via Kategatt) and the Baltic. There is a marked gradient

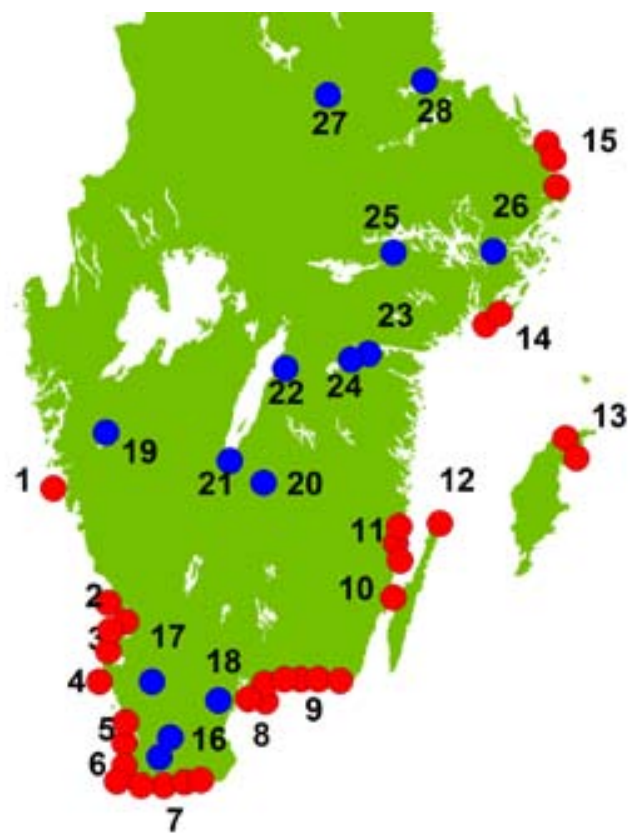

Figure 3. Map showing the geographical position of the reference areas (see text!), which, together with the counting units of Figure 2, are included in the national network of sites counted annually for the calculation of winter indices.

Karta utvisande läget av referensområden (se texten), vilka, tillsammans med standardlokalerna i Figur 2, ingår $i$ nätverket av lokaler som utnyttjas för beräkning av de årliga index.

Coastal areas Kustlokaler: 1. Southern archipelago of Gothenburg, 2. Falkenberg - Båstad, 3. Skälderviken, 4. N. Öresund, 5. Lundåkrabukten + Lommabukten (central Öresund), 6. Foteviken area - Falsterbo (S. Öresund), 7. South coast of Scania, 8. Landön - Pukavik, 9. Blekinge archipelago, 10. Kalmar - Revsudden, 11. N. Kalmarsund, 12. N. Öland, 13. N Gotland, 14. Landsort - Muskö, 15. Väddö.

Inland areas Inlandslokaler: 16. Lakes in SW Scania, 17. Finjasjön, 18. Araslövsjön - Hammarsjön (Kristianstad Vattenrike), 19. Säveån, 20. Ingsbergasjön, 21. Jönköping (Bay of Vättern + small lakes), 22. Motala, 23. Norrköping, 24. Roxen - Glan, 25. Eskilstunaån, 26. Stockholm, 27. Falun and 28. Gävle. from the saline waters in the north to the brackish waters in the south. The southern part of the Öresund from Lundåkrabukten-Falsterbo (reference areas 4, 5 in Figure 3) is characterized by vast areas of shallow water with extensive meadows of Zostera and similar vegetation. The shallow areas are relatively often ice-covered during colder periods.

The south and east coast of Scania (D) is characterized of brackish water with open shores, large sandy beaches alternating with moraine shores (Figure 4A). Shallow water is mostly restricted to the innermost areas.

The southernmost archipelago, Blekinge in the southeast (E) is different in character from the archipelagos further north in the Baltic not being so wide and with many moraine islands and larger areas of open water, often shallow with extensive Zostera meadows (Figure 4B,C). Open water is normally available in this archipelago in most, even colder winters. The vegetation on the islands is broad-leaved compared to coniferous in the other Baltic archipelagos.

The Kalmarsund (F, G) forms a transition between the southern archipelago type of Blekinge and the typical archipelagos of the Baltic from the northernmost part of the province of Kalmar to the Stockholm archipelago $(\mathrm{H}, \mathrm{M}-\mathrm{O})$. The southern part $(\mathrm{F})$ has a low-lying moraine coast with a few islands and extensive areas of shallow water. In the northern part $(\mathrm{G})$ the islands are of the same type as in the other Baltic archipelagos but the archipelago is not so wide (Figure 4D,E). The inner bays are mostly ice-covered for periods except in the mildest winters but normally there is open water in parts of Kalmarsund

The northern archipelagos $(\mathrm{H}, \mathrm{M}-\mathrm{O})$ are wide, in the Stockholm region (O) extending about 70 $\mathrm{km}$ from the outer islets to the mainland in some places. On the mainland coast in this part of the Baltic coast there are many bays with shallow water and submerged vegetation, the water being deeper between the islands further out. In the typical archipelago there is a gradient from the inner larger wooded islands separated by vast areas of open water, to smaller groups of islands and finally smaller islets and sea shallows. The water is often deep between the island groups but extensive shallow areas are to be found in the island groups. In normal years, parts of the archipelagos are covered with ice at least in the inner parts, whereas they can be more or less completely ice-covered during the coldest winters.

The two islands Öland (K) and Gotland (L) are treated separately. Both islands are characterized 

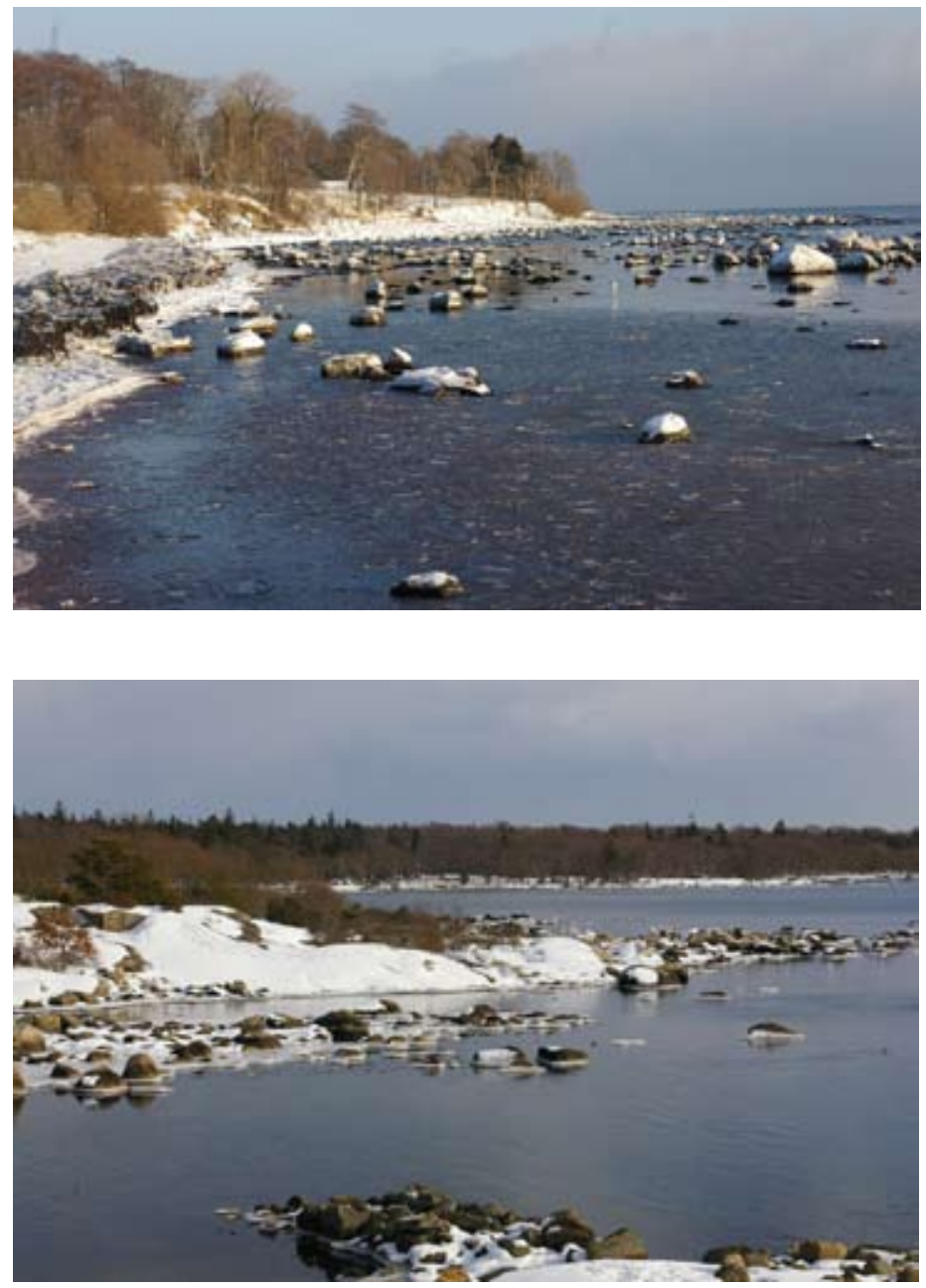

B. Blekinge archipelago (E)

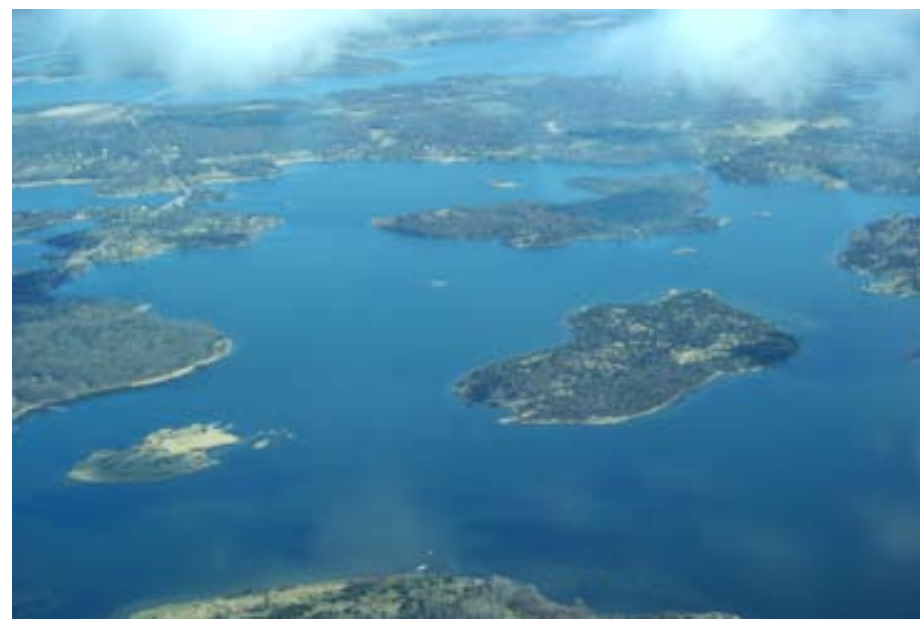

C. Blekinge archipelago (E)
A. South coast of Scania (D)

Figure 4. Photographs of some waterbird habitats along the Swedish coasts. Foton av olika sjöfågelbiotoper efter den svenska kusten. 
D. Kalmar archipelago (G)

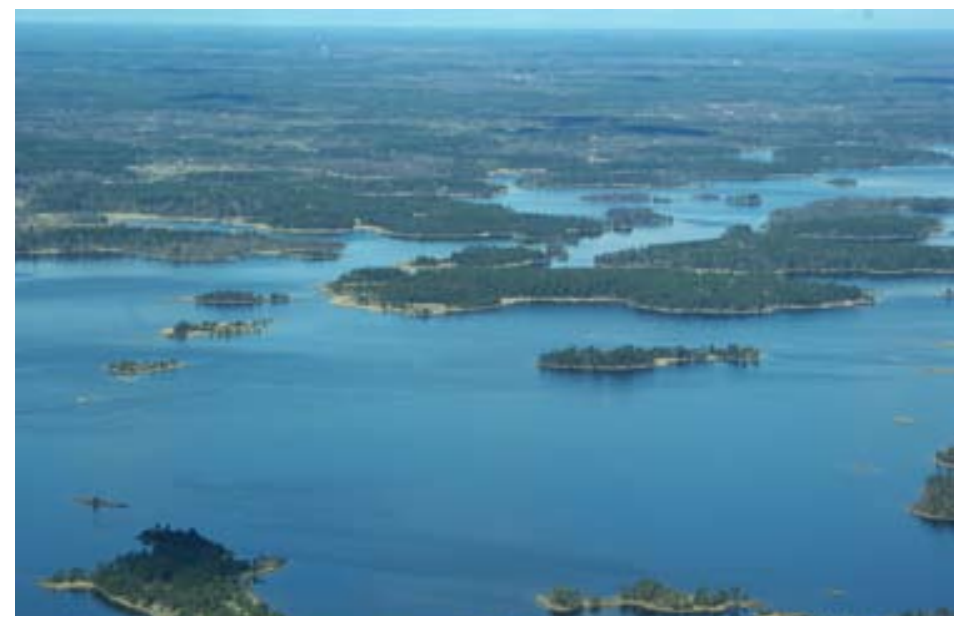

E. Kalmar archipelago (G)

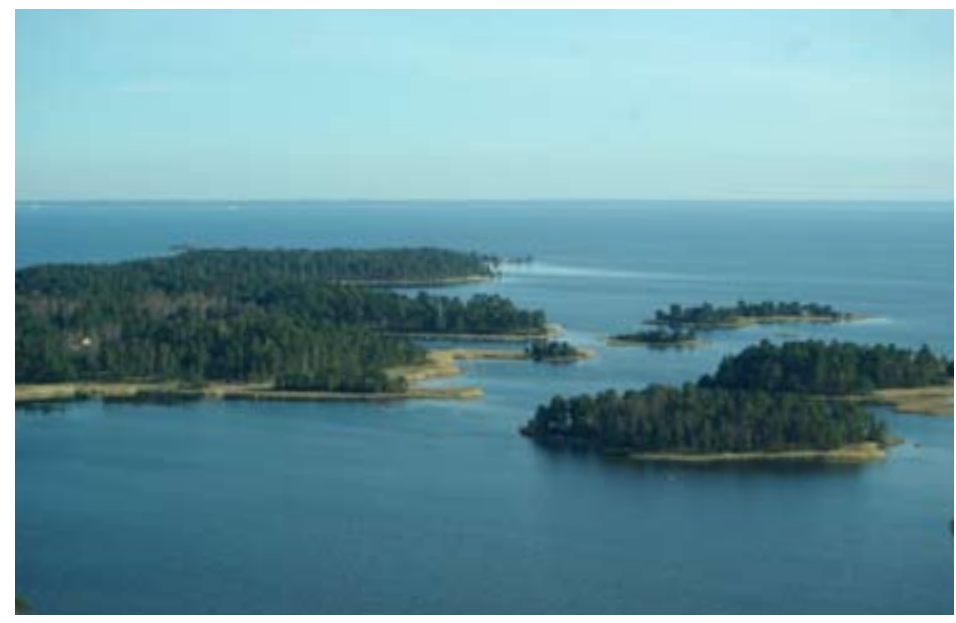

F. East coast of Öland (K)

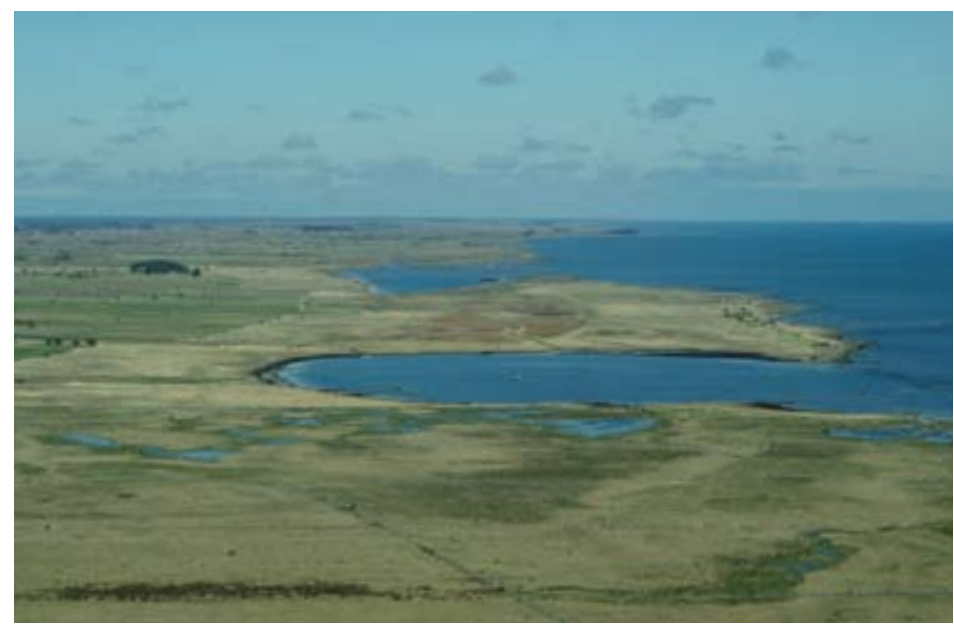


by calciferous rocks with mostly deep water in the west and large areas of shallow waters to the east. Large parts of the west coasts of both islands have a cliff coast, whereas the east coasts are more shallow, with a mixture of sandy beaches and shoremeadows (Figure 4F). Most areas on Gotland are ice-free except during colder periods. The same applies to the east coast of Öland but the Kalmarsund side freeze quite often at least in parts.

In the analysis of country-wide surveys, the country is divided into three larger areas, partly due to the possibilities to obtain full coverage of inshore areas (Figure 1). South Sweden consists of the area from northern Kategatt to northern Kalmarsund, incl. Öland and Gotland (regions A-G, k and L). In this area it is possible to cover all areas of importance for the inshore species with landbased counters. The other two larger areas are the west coast $(\mathrm{V})$ or province of Bohuslän and the east coast archipelagos $(\mathrm{H}, \mathrm{M}-\mathrm{O})$.

\section{Counting methods}

During the ground counts the observer covered the counting unit(s) either by walking the shore line or from vantage points using telescope, moving between counting points as fast as possible to minimize the effects of movements of the birds. One counting unit was normally covered within the same day.

In the seventies boat surveys were performed in the archipelago areas. These counts were made from patrol boats of the Swedish Coast Guard which offered good observation possibilities from the bridge or the foredeck. The boats normally had a speed of about 10 knots during the surveys and went through the areas to be covered in such a way that the entire counting units could be checked for the occurrence of waterbirds.

Aerial surveys started in January 1971. In the first two winters, 1971 and 1972, aerial surveys were mainly made from military aircraft: single-engined SK 50 (Saab Safir) or Piper Super Cub with pilots from the Swedish Air force. During the same years and in 1973-1977 aerial surveys were also performed from a Rally Commodore. CESSNA 172 was used on some occasions. In 1987-1989, single-engined aircraft (CESSNAs) were used for inshore waters, whereas a twin-engined CESSNA 337 was used for some surveys. In 2004 all aerial surveys were undertaken from a CESSNA 337.

During the aerial surveys we were flying at an altitude of 50-70 $\mathrm{m}$ above sea level. On open coasts the flight track was a few hundred meters from the shore line so that the entire area between the aircraft and the shore could be covered efficiently. In the archipelagos and in bays the flight track was laid so that the entire area could be effectively covered. Large flocks were checked several times and in many cases photos were taken to check the visual estimates of the same flock. With the singleengined aircraft the air speed was about 120-130 $\mathrm{km} / \mathrm{h}$, whereas the CESSNA 337 was somewhat faster, $160-180 \mathrm{~km} / \mathrm{h}$. Aerial surveys were only made during good weather conditions, i.e. relatively calm sea and good visibility. Similar methods were used in aerial surveys of Danish waters (Joensen 1968, 1974).

Normally at least two observers were employed, the observer in the front seat was responsible for navigation within survey units and also for recording all bird observations on tape. The second observer was seated behind the pilot (not applicable in the two-seated Super $\mathrm{Cub}$ ). The data were later transformed to a data-base.

The efficiency of the aerial surveys (numbers counted as per cent of numbers actually present in the survey area) varies between different species and also between different weather conditions and not least between different observers. These aspects of aerial surveys were studied extensively during the early seventies when parallel ground/ air counts were undertaken in selected areas to establish the proportion of the birds present actually seen from the air. For a discussion of these factors see Nilsson (1975).

\section{Index calculations}

Annual indices for the different species were calculated as "chain-indices". One year was selected as base-year for the calculations and the index for that year was set to 100 . The primary indices for the years before and after the base-year were obtained by calculating the totals for all sites counted in Year $\mathrm{A}$ and Year $\mathrm{A}+1$. The total of Year $\mathrm{A}+1$ expressed as per cent of the total for the same sites in Year A gives the primary index for Year $\mathrm{A}+1$. The primary indices were then recalculated in relation to the index of the base year $=100$. Finally the indices were normalized so that the mean of the entire series of annual indices was 100 . For further description of index calculations and discussion of methodological questions in relation to the calculation of indices see Nilsson $(1975,1976)$. 


\section{Coverage of the counts}

In the first years it was attempted to get full coverage of all open coasts from the province of Halland to Kalmarsund and Öland and Gotland with observers counting from the ground (south Sweden in Figure 1). Inland and in the archipelagos it was tried to cover as many sites as possible. Boat counts from the Coast Guard patrols supplemented ground counts in the archipelagos (in all about 100 patroldays). The number of sites covered with counts has varied between 355 in the first winter 1967 and 1712 in January 1972 with extensive aerial surveys (the more than 1900 sites in Table 1 for 1987 includes hundreds of sites that were ice-covered). After the standardization of the scheme about 600 700 counting units (the majority of them being found in the reference areas) have been reported each year, of which between 500 and 600 were used for index calculations. The number of registered counters in different winters has been between 113 and 320 plus an unknown number of helpers. The total number of counters since the start exceeded 2000 .

After the initial years of the International Midwinter Counts it was realised that total coverage was not possible to attain on an annual basis for countries with as vast coastlines and large numbers of inland water areas as Sweden and the counts were concentrated to cover an adequate sample of counting units for the calculation of annual population indices. In addition to this annual sample full cover surveys of all inshore coastal waters and the inland were made at larger intervals. The northern limit of the areas covered (See Figure1) was in the province of Uppland, areas north of this normally being ice-covered in January when the programme started. These total counts included both ground counts and aerial surveys and during the first period boat surveys.

The first country-wide survey was undertaken in 1971-1973. 96 hours of aerial surveys (excluding transfer time) were used in addition to ground and boat counts. The inshore areas of south Sweden (Figure 1) were fully covered in all years, whereas Bohuslän (V) was fully covered by aerial surveys only in 1971. There were some gaps in the Stockholm archipelago during the first years but these parts were covered 1972-1973 with some additional areas surveyed in 1974. The weather of the four years was similar. In the estimates of total wintering populations for the entire country, 1971 was used as a basis and estimates for missing areas in parts of the Baltic archipelagos were imputed, based on the counts in the later years, whereas mean counts for the counting units from all years were used for the maps.

In 1987-1989 a new period of country-wide surveys was planned to cover the areas shown in Figure 1 . About 25 hours were used in aerial surveys in addition to extensive ground counts. In all three years the inshore waters of South Sweden were covered, mainly with ground counts, whereas aerial surveys were undertaken in the archipelagos on the west coast. However, due to the weather conditions it was not possible to make any aerial surveys in the east coast archipelagos.

The third country-wide survey was made in 2004 and due to good weather conditions practically all inshore areas shown in Figure 1 were covered in 25 hours of aerial surveys plus ground counts along open shores. With the change in climate towards milder winters open water is available further north along the coast of the Bothnian Sea and in 2004 the counts were extended to cover also these waters. 48 hours of additional aerial surveys were performed along the east coast in 1974-1978. During 19711981 exactly 100 patrol days were spent on counts from the Coastguard patrol boats.

A number of the reference (Figure 3) areas have been covered completely every year since the larger surveys in 1987-1989 (Nilsson 1991) and the totals from for all reference areas are used to elucidate annual fluctuations for species where the data does not permit the calculation of annual indices. Some reference areas have been covered completely since the early seventies (or from the start) and have been used to analyse annual fluctuations of some species on a regional level.

\section{Results}

\section{Weather and ice situation}

The weather, especially the ice situation, is of a very large importance for the distribution of waterbirds as they depend on open water that is not too deep. To get a general idea of the hardness of the winter I have calculated the means of the monthly mean temperatures for January for ten weather stations spread over the part of Sweden covered by the Midwinter Counts (Figure 5).

In general, the January temperatures in the first twenty years of midwinter counts were lower than in the second twenty year period (Figure 5). When the counts started, mean January temperatures were low and the first cold winter with extensive ice during time series occurred in 1970. Three winters in the early seventies (1973-1975) were mild with 
Table 1. Total number of sites covered at the midwinter counts in Sweden in different years split on coastal and inland sites. Index-sites $=$ the number of sites used in the index-comparisons with the preceding year.

Antalet lokaler täckta vid midvinterinventeringarna I Sverige olika år uppdelat på kust och inlandslokaler. Index-lokaler $=$ det antal lokaler som ingår $i$ index-jämförelsen med föregående år.

\begin{tabular}{|c|c|c|c|c|c|}
\hline \multirow[t]{2}{*}{$\begin{array}{l}\text { Year } \\
\text { Ar }\end{array}$} & \multicolumn{3}{|c|}{$\begin{array}{l}\text { Total number of sites counted } \\
\text { Antal inventerade lokaler }\end{array}$} & \multirow[t]{2}{*}{$\begin{array}{r}\text { Indexsites } \\
\text { Indexlokaler }\end{array}$} & \multirow[t]{2}{*}{$\begin{array}{r}\text { Number of counters } \\
\text { Antal inventerare }\end{array}$} \\
\hline & $\begin{array}{r}\text { Coast } \\
\text { Kust } \\
\end{array}$ & $\begin{array}{l}\text { Inland } \\
\text { Inland }\end{array}$ & $\begin{array}{r}\text { Total } \\
\text { Summa }\end{array}$ & & \\
\hline 1967 & 234 & 121 & 355 & & 126 \\
\hline 1968 & 215 & 179 & 394 & 192 & 170 \\
\hline 1969 & 475 & 218 & 693 & 330 & 226 \\
\hline 1970 & 402 & 264 & 666 & 585 & 290 \\
\hline 1971 & 1318 & 309 & 1627 & 620 & 320 \\
\hline 1972 & 1311 & 401 & 1712 & 1094 & 198 \\
\hline 1973 & 1240 & 447 & 1687 & 1156 & 220 \\
\hline 1974 & 891 & 283 & 1174 & 788 & 225 \\
\hline 1975 & 818 & 307 & 1125 & 657 & 245 \\
\hline 1976 & 840 & 293 & 1133 & 688 & 192 \\
\hline 1977 & 827 & 206 & 1033 & 765 & 168 \\
\hline 1978 & 773 & 212 & 985 & 773 & 228 \\
\hline 1979 & 439 & 192 & 631 & 517 & 150 \\
\hline 1980 & 393 & 175 & 568 & 448 & 130 \\
\hline 1981 & 407 & 131 & 538 & 414 & 118 \\
\hline 1982 & 433 & 120 & 553 & 462 & 113 \\
\hline 1983 & 397 & 109 & 506 & 423 & 162 \\
\hline 1984 & 317 & 92 & 409 & 355 & 117 \\
\hline 1985 & 336 & 79 & 415 & 352 & 134 \\
\hline 1986 & 359 & 76 & 435 & 370 & 136 \\
\hline 1987 & 1694 & 223 & 1917 & 417 & 190 \\
\hline 1988 & 787 & 456 & 1243 & 864 & 288 \\
\hline 1989 & 832 & 405 & 1237 & 953 & 287 \\
\hline 1990 & 464 & 219 & 683 & 603 & 184 \\
\hline 1991 & 459 & 168 & 627 & 531 & 149 \\
\hline 1992 & 392 & 173 & 565 & 489 & 156 \\
\hline 1993 & 476 & 183 & 659 & 463 & 159 \\
\hline 1994 & 458 & 187 & 645 & 538 & 145 \\
\hline 1995 & 486 & 190 & 676 & 577 & 171 \\
\hline 1996 & 486 & 157 & 643 & 549 & 133 \\
\hline 1997 & 491 & 165 & 656 & 576 & 136 \\
\hline 1998 & 520 & 151 & 671 & 540 & 190 \\
\hline 1999 & 466 & 145 & 611 & 531 & 158 \\
\hline 2000 & 476 & 161 & 637 & 530 & 160 \\
\hline 2001 & 460 & 161 & 621 & 546 & 185 \\
\hline 2002 & 477 & 152 & 629 & 545 & 190 \\
\hline 2003 & 486 & 141 & 627 & 560 & 186 \\
\hline 2004 & 687 & 331 & 1018 & 435 & 290 \\
\hline 2005 & 532 & 153 & 685 & 609 & 242 \\
\hline 2006 & 547 & 170 & 717 & 612 & 220 \\
\hline
\end{tabular}




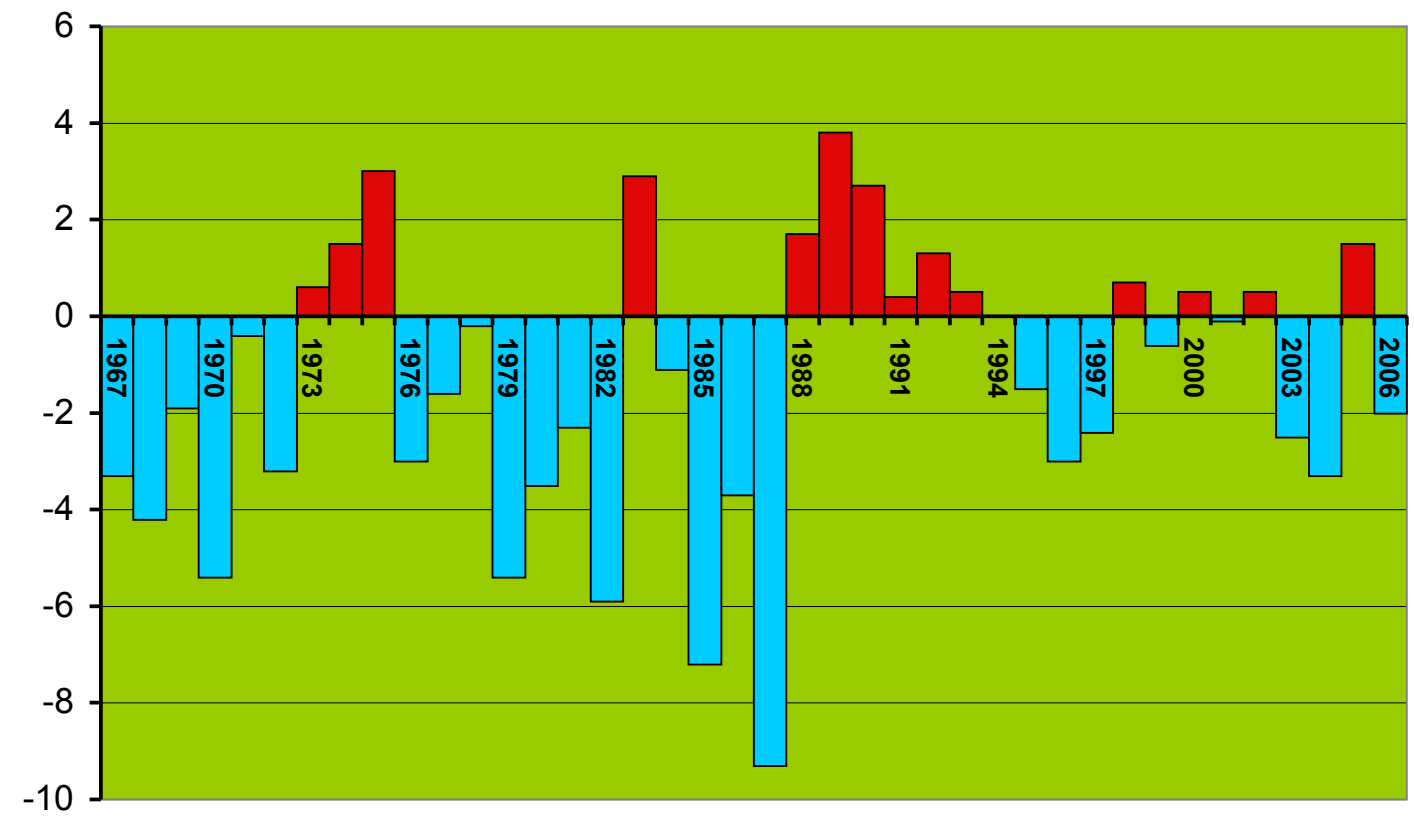

Figure 5. Annual means of monthly mean temperatures for January for ten meterological stations spread over south Sweden over the area covered by Midwinter Counts. (From the monthly reports of the Swedish Metrological and Hydrological Institute).

Arsmedeltal av de månatliga medeltemperaturerna för januari på tio väderstationer spridda over södra Sverige (Från SMHIs månatliga rapporter).

above zero mean temperatures for the ten stations together. Then a very cold winter with much ice followed in 1979. The following winters were characterized by cold weather and much ice at sea even in southernmost Sweden except for the mild winter 1983. January 1982, 1985 and especially 1987 were very hard ice winters with only little available open water along the coasts of the Baltic and also with much ice on the west coast. 1987 was extreme with almost all inshore parts from the Stockholm archipelago to Kattegat ice covered for some periods, larger areas of shallow water being available only east of Öland and around Gotland and with smaller open areas on the mainland coast. After 1987, there has been no real hard ice winter, even if there was quite extensive ice coverage for shorter periods in 1996 and 1997.

The coastal ice-coverage is exemplified in four maps based on data from the Swedish Metorological and Hydrological Institute, illustrating the icecoverage in Swedish coastal waters during 1971 and 2004, i.e. the years with the most extensive surveys, and the two cold winters of 1979 and 1987 (Figure 6). The ice coverage in 1982 and 1985 was similar to that in the two cold winters exemplified in Figure 6, whereas the ice coverage in 1970 was somewhat less extensive.

Normally, there has been some ice coverage in the archipelagos in most years, but with much variation between years and regions and also within the counting periods, when in more normal winters, the wind has moved the ice in the outer parts of archipelagos and open coasts quite a lot.

Generally, the open coasts (regions A-D, K and L, Figure 1) have only had extensive ice coverage in the winters classified as real cold, but normally some open water has been available at least close to harbours, power plants etc. The southernmost archipelago, Blekinge (E) has regularly had ice coverage in the innermost parts in most winter, but larger open areas were available further out except in the coldest of ice winters, but even in those years there were some areas free of ice.

Kalmarsund (F and G, Figure 1) normally had ice coverage in the inner areas, but there were quite marked movements of the ice and except for the coldest winters there were some open areas for wintering waterfowl. In the east coast archipela- 


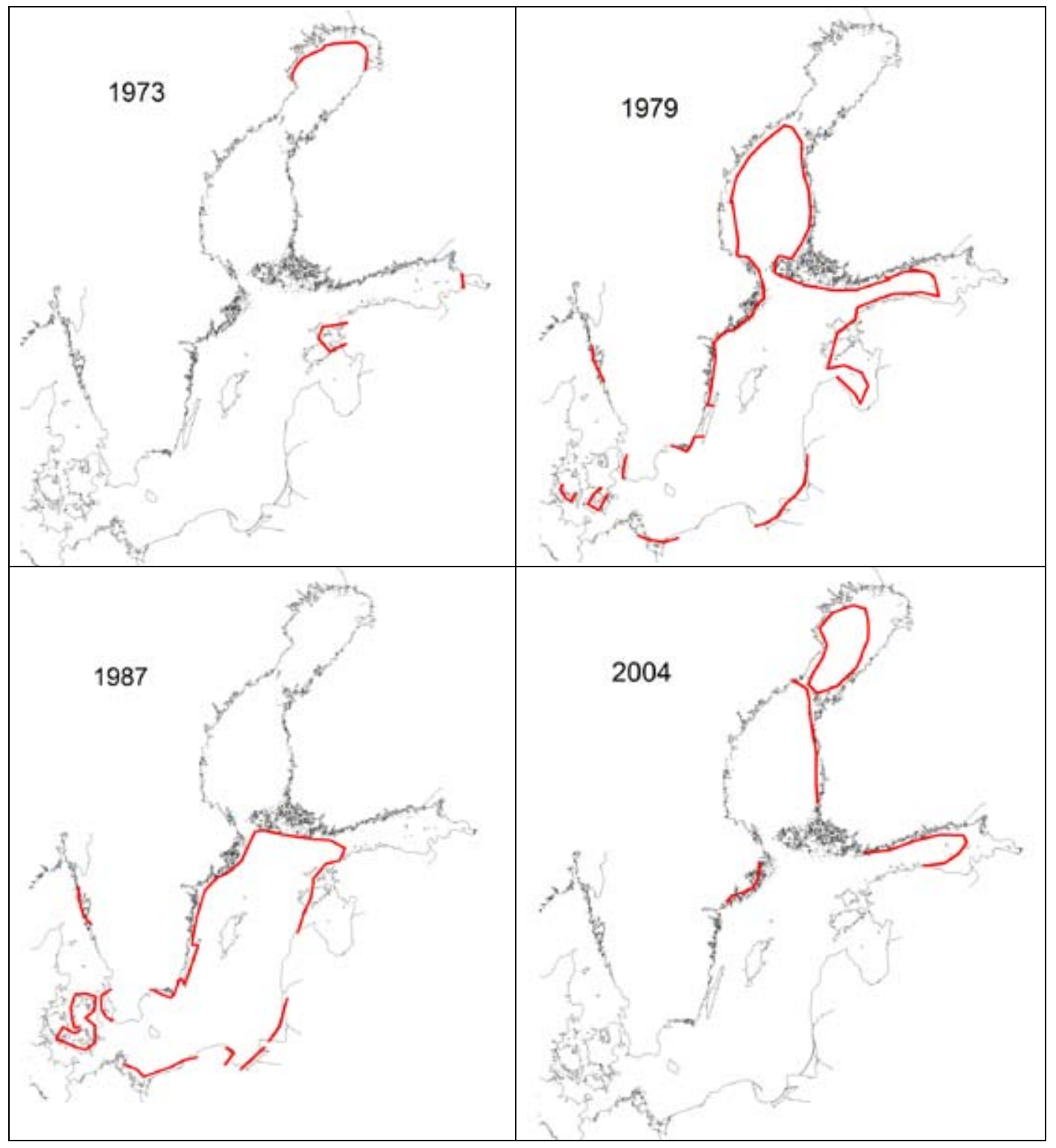

Figure 6. Ice charts for the Baltic Sea for the two winters with extensive country wide surveys (1971 and 2004) and for two of the hardest ice-winters $(1979,1987)$. The border of ice against open water is shown with lines. Based on official ice charts from the Swedish Metrological and Hydrological Institute.

Iskartor för Östersjön under två vintrar med landsomfattande inventeringar (1971 och 2004) samt för två av de hårdaste isvintrarna (1979, 1987). Isgränsen mot öppet vatten markeras av linjer. (Från SMHIs officiella iskartor). 
gos there was sea ice in the inner parts in normal years but except for the coldest winters there was normally some open areas in the outer parts of the archipelagos.

The lakes were generally ice covered with the exception of the southernmost province, Scania, where open water was available during milder winters, i.e. during the early 1970 s and in several winters after 1988 even if there were also shorter ice-periods. Inland ice-free sites in other parts of Sweden were normally found only on streaming water with some exceptions. In the large and deep Lake Vättern open water was available except during the coldest winters.

For details on the weather and ice situation see the annual reports from the project listed in the appendix and for later reports on the homepage of the project (from which they can be down-loaded).

\section{Wintering waterbird populations}

Total population estimates for the different species in the entire surveyed area are presented in Table 2 for 1971 and 2004, i.e. the years with complete counts, although only Anatidae, Cormorants Phalacrocorax carbo and Coot Fulica atra were counted in 1971. The total wintering population of waterbirds in Sweden (excl. offshore areas but including inland areas) in January 2004 was estimated to be 622000 individuals compared to 173000 in 1971. In both years total counts for the offshore species Long-tailed Duck Clangula hyemalis, Velvet Scoter Melanitta fusca and Common Scoter Melanitta nigra were not available. Some of the species included in the table such as Red-breasted Merganser Mergus serrator may also occur offshore to some extent, so the estimates are minima. It is however clear from offshore surveys in progress (Nilsson in prep., Durinck et al. 1994) that the offshore numbers of Long-tailed Ducks in Swedish Baltic areas are appreciably higher than the total number of all other species taken together.

The most common species in the inshore (incl. inland) Swedish waters was the Tufted Duck Aythya fuligula, followed by the Mallard Anas platyrhynchos and the Goldeneye Bucephala clangula (Table 2). Whereas the total estimate for the Tufted Duck is considered to be quite accurate, the species occurring in large flocks easy to detect from the air, the estimate for the Mallard is somewhat more uncertain, but it is clear that it was less common than the Tufted Duck in 2004, whereas the situation was the opposite in 1971. Problems with the Mallard are related to its occurrence inland, where
Table 2. Total estimated wintering populations of different waterbirds species in Sweden in 1971 and 2004. For species marked with grey there are no population estimates for the year. (Some species were not counted in 1971 (marked with grey) and for the seaducks offshore data are lacking both in 1971 and 2004) Uppskattat antal övervintrande individ I Sverige av olika sjöfågelarter 1971 och 2004. För arter markerade med grått saknas beståndsuppskattning för resp. år. (Några arter inventerades inte 1971 (gråmarkerat), medan data för de havslevande dykänderna saknas från de yttre havsområdena).

\begin{tabular}{|c|c|c|}
\hline Species Art & 1971 & 2004 \\
\hline Anas platyrhynchos & 67300 & 150000 \\
\hline Anas crecca & 10 & 320 \\
\hline Anas penelope & 10 & 5700 \\
\hline Anas strepera & 0 & 10 \\
\hline Anas acuta & 5 & 20 \\
\hline Anas clypeata & 0 & 1 \\
\hline Aythya marila & 1100 & 3200 \\
\hline Aythya fuligula & 54000 & 230000 \\
\hline Aythya ferina & 100 & 2750 \\
\hline Bucephala clangula & 18800 & 75000 \\
\hline \multicolumn{3}{|l|}{ Clangula hyemalis } \\
\hline \multicolumn{3}{|l|}{ Melanitta fusca } \\
\hline \multicolumn{3}{|l|}{ Melanitta nigra } \\
\hline Somateria mollissima & 4600 & 50000 \\
\hline Mergus serrator & 2500 & 6000 \\
\hline Mergus merganser & 8600 & 25000 \\
\hline Mergus albellus & 400 & 3800 \\
\hline Tadorna tadorna & 5 & 20 \\
\hline Cygnus olor & 7500 & 35000 \\
\hline Cygnus cygnus & 2100 & 9500 \\
\hline Fulica atra & 4000 & 18000 \\
\hline Phalacrocorax carbo & 1000 & 12000 \\
\hline Subtotal Delsumma & 172870 & 621321 \\
\hline Aredea cinerea & & 1000 \\
\hline Gavia arctica & & 120 \\
\hline Gavia stellata & & 20 \\
\hline Podiceps cristatus & & 5000 \\
\hline Podiceps griseigena & & 50 \\
\hline Podiceps auritus & & 80 \\
\hline Tachybaptus ruficollis & & 100 \\
\hline Total Summa & 172870 & 627691 \\
\hline
\end{tabular}

it is difficult to find all flocks in a situation with a large number of smaller groups compared to the coastal situation.

The comparison of the two complete countrywide surveys of inshore waters show marked increases for the total Swedish wintering population of waterbirds as well as for most species (Tables 
Table 3.Total numbers of wintering waterbirds counted in the province of Bohuslän, Swedish west coast archipelagos (Region V in Fig.1) at surveys covering the entire province. Species marked with grey for 1971 were not counted during that year.

Antal övervintrande sjöfåglar i Bohuslän, svenska västkusten (region V, Fig. 1) vid inventeringar som täckte hela provinsen. Arter markerade med grått 1971 inventerades inte det året.

\begin{tabular}{lrrrrr}
\hline Species Art & 1971 & 1987 & 1988 & 1989 & 2004 \\
\hline Anas platyrhynchos & 1083 & 3023 & 4315 & 2333 & 7055 \\
Anas crecca & 0 & 0 & 0 & 0 & 11 \\
Anas penelope & 0 & 0 & 2 & 0 & 1 \\
Anas strepera & 0 & 1 & 0 & 0 & 1 \\
Anas acuta & 0 & 0 & 0 & 0 & 0 \\
Aythya marila & 0 & 0 & 25 & 0 & 10 \\
Aythya fuligula & 1020 & 4 & 82 & 0 & 328 \\
Aythya ferina & 40 & 1 & 3 & 0 & 3 \\
Bucephala clangula & 996 & 1242 & 2967 & 1803 & 13161 \\
Clangula hyemalis & 87 & 0 & 0 & 81 & 11 \\
Polysticta stelleri & 0 & 0 & 0 & 0 & 0 \\
Somateria mollissima & 2881 & 1918 & 4702 & 5549 & 36582 \\
Melanitta fusca & 10 & 0 & 131 & 136 & 13 \\
Melanitta nigra & 14 & 11 & 56 & 128 & 76 \\
Mergus serrator & 214 & 427 & 1006 & 1076 & 1313 \\
Mergus merganser & 114 & 790 & 356 & 66 & 1020 \\
Mergus albellus & 0 & 10 & 9 & 0 & 52 \\
Tadorna tadorna & 0 & 0 & 5 & 1 & 10 \\
Cygnus olor & 1007 & 1393 & 1680 & 913 & 3287 \\
Cygnus cygnus & 167 & 709 & 374 & 230 & 316 \\
Fulica atra & 40 & 3 & 1 & 0 & 235 \\
Phalacrocorax carbo & 172 & 1503 & 1601 & 652 & 3438 \\
Aredea cinerea & & 0 & 18 & 121 & 99 \\
Gavia arctica & & 0 & 28 & 5 & 2 \\
Gavia stellata & & 0 & 2 & 1 & 0 \\
Podiceps cristatus & & 0 & 0 & 0 & 2 \\
Podiceps griseigena & & 0 & 0 & 0 & 2 \\
Podiceps auritus & & 0 & 0 & 5 & 17 \\
Tachybaptus ruficollis & & 035 & & 697 & 67050 \\
\hline Total Summa & & & 0 &
\end{tabular}

2-5). The changes in the larger regions are generally in the same direction and magnitude as the changes in the overall population estimates. The different species will be further discussed in the species accounts.

\section{Regional composition of wintering waterfowl populations}

As is apparent from Tables 3-5, marked differences in the composition of the wintering waterbird communities were found between different parts of Sweden, not only betweencoast and inland but also between different coastal regions (Figure 7).

On the west coast and especially in the archipela- gos of the province of Bohuslän, the Eider Somateria mollissima was dominant, accounting for close to $50 \%$ of the birds. The Goldeneye was also an important species followed by the Mallard on the third place. The Eider was still important along the coasts of Kattegat (including Skälderviken), but it was much less dominant here, the Mallard being the most common duck instead.

The waterbird community showed marked change in the composition when going from the Kattegat into the Öresund. The dominance for the Mallard was less marked in Öresund and instead the Tufted Duck was an important species as well as the Coot even if less common than the other two. Mute Swans Cygnus olor were also common. The 
Table 4. Total numbers of wintering waterbirds counted along coasts of south Sweden from Halland to Kalmarsund including Öland and Gotland (regions A-G, K and L, Fig. 1) at surveys covering the inshore areas of the entire region. Species marked with grey for 1971 were not counted during that year. For Clangula hyemalis, Melanitta fusca and Melanitta nigra, (marked with grey in the table) only a small proportion of the total populations are found close to the shore, so the figures presented do not represent total population estimates for the regions but are the numbers actually counted in surveys of the inshore areas.

Antalet övervintrande sjöfåglar räknade längs kusterna av södra Sverige från Halland till Kalmarsund samt Öland och Gotland (regionerna A-G, Koch L, Fig. 1) vid räkningar som täckte de inre farvattnen i hela regionen. Arter markerade med grått 1971 räknades inte det året. För alfågel, svärta och sjöorre (markerade med grått i tabellen) återfinns endast en mindre andel av det totala beståndet nära stranden, varför de angivna siffrorna inte representerar några beståndsskattningar utan endast anges vad som räknats vid inventeringarna av de inre farvattnen.

\begin{tabular}{|c|c|c|c|c|c|c|c|}
\hline Species Art & 1971 & 1972 & 1973 & 1987 & 1988 & 1989 & 2004 \\
\hline Anas platyrhynchos & 22310 & 33630 & 33290 & 18852 & 32997 & 44137 & 60476 \\
\hline Anas crecca & 7 & 2 & 68 & 11 & 38 & 36 & 297 \\
\hline Anas penelope & 3 & 13 & 74 & 0 & 247 & 450 & 5560 \\
\hline Anas strepera & 0 & 0 & 0 & 0 & 0 & 2 & 6 \\
\hline Anas acuta & 4 & 3 & 3 & 2 & 3 & 9 & 14 \\
\hline Aythya marila & 1100 & 121 & 364 & 216 & 3398 & 2481 & 2854 \\
\hline Aythya fuligula & 35780 & 40950 & 66510 & 51085 & 48422 & 61715 & 145714 \\
\hline Aythya ferina & 52 & 202 & 351 & 186 & 837 & 1188 & 2500 \\
\hline Bucephala clangula & 14970 & 17360 & 24150 & 23552 & 21427 & 19468 & 30644 \\
\hline Clangula hyemalis & 11312 & 29509 & 35192 & 10753 & 8144 & 7974 & 30934 \\
\hline Polysticta stelleri & 5 & 6 & 4 & 46 & 6 & 57 & 2 \\
\hline Somateria mollissima & 1307 & 2347 & 2663 & 1388 & 2122 & 1994 & 10725 \\
\hline Melanitta fusca & 662 & 2157 & 2570 & 31 & 843 & 700 & 1155 \\
\hline Melanitta nigra & 626 & 431 & 221 & 14 & 193 & 537 & 4316 \\
\hline Mergus serrator & 1865 & 2272 & 3664 & 3833 & 3599 & 2791 & 3913 \\
\hline Mergus merganser & 4070 & 2826 & 4490 & 8218 & 2453 & 3481 & 8539 \\
\hline Mergus albellus & 348 & 177 & 377 & 384 & 214 & 347 & 3295 \\
\hline Tadorna tadorna & 2 & 1 & 19 & 0 & 11 & 173 & 10 \\
\hline Cygnus olor & 4407 & 4610 & 5770 & 7817 & 7165 & 8424 & 20800 \\
\hline Cygnus cygnus & 1247 & 902 & 859 & 975 & 414 & 467 & 1084 \\
\hline Fulica atra & 3700 & 6264 & 9330 & 1710 & 1890 & 1560 & 14472 \\
\hline Phalacrocorax carbo & 518 & 812 & 563 & 1356 & 2343 & 1729 & 5648 \\
\hline Aredea cinerea & & 15 & 34 & 21 & 75 & 72 & 392 \\
\hline Gavia arctica & & 1 & 1 & 2 & 52 & 10 & 112 \\
\hline Gavia stellata & & 2 & 2 & 1 & 212 & 91 & 14 \\
\hline Podiceps cristatus & & 9 & 6 & 57 & 83 & 53 & 4285 \\
\hline Podiceps griseigena & & 0 & 0 & 4 & 11 & 9 & 33 \\
\hline Podiceps auritus & & 2 & 3 & 0 & 2 & 1 & 70 \\
\hline Tachybaptus ruficollis & & 0 & 0 & 1 & 1 & 4 & 76 \\
\hline Total Summa & 104295 & 144624 & 190578 & 130515 & 137202 & 159960 & 357940 \\
\hline
\end{tabular}

Eider was only counted in smaller numbers especially in the southern part of Öresund. This species is normally mostly confined to the west coast and only occurs in small numbers in the Baltic waters.

The south coast of Scania (and Sweden) showed a different picture from the Öresund, which in fact is a transition zone from the western seas and the Baltic. In all Baltic regions the Long-tailed Duck is an important species even if the counts in inshore waters do not show the full importance of the species that mostly is found well offshore. On the south coast three more species are common, the Mallard, the Goldeneye and the Tufted Duck. The proportion between the different species show marked variation between years in relation to the winter situation further to the north on the coast as 


\section{Bohuslän}

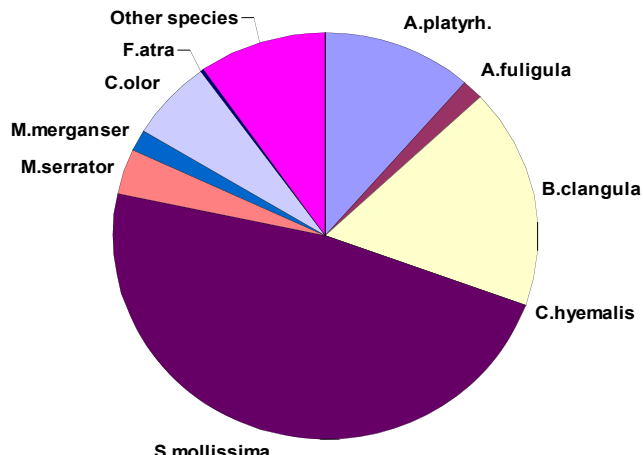

S.mollissima
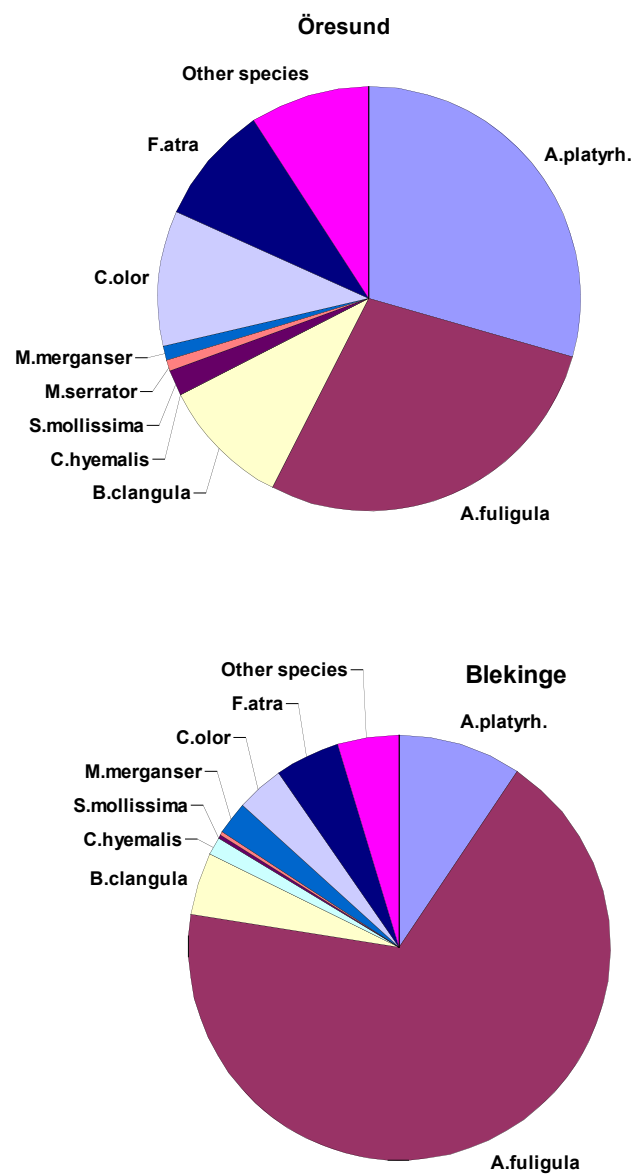

Halland + Skälderviken
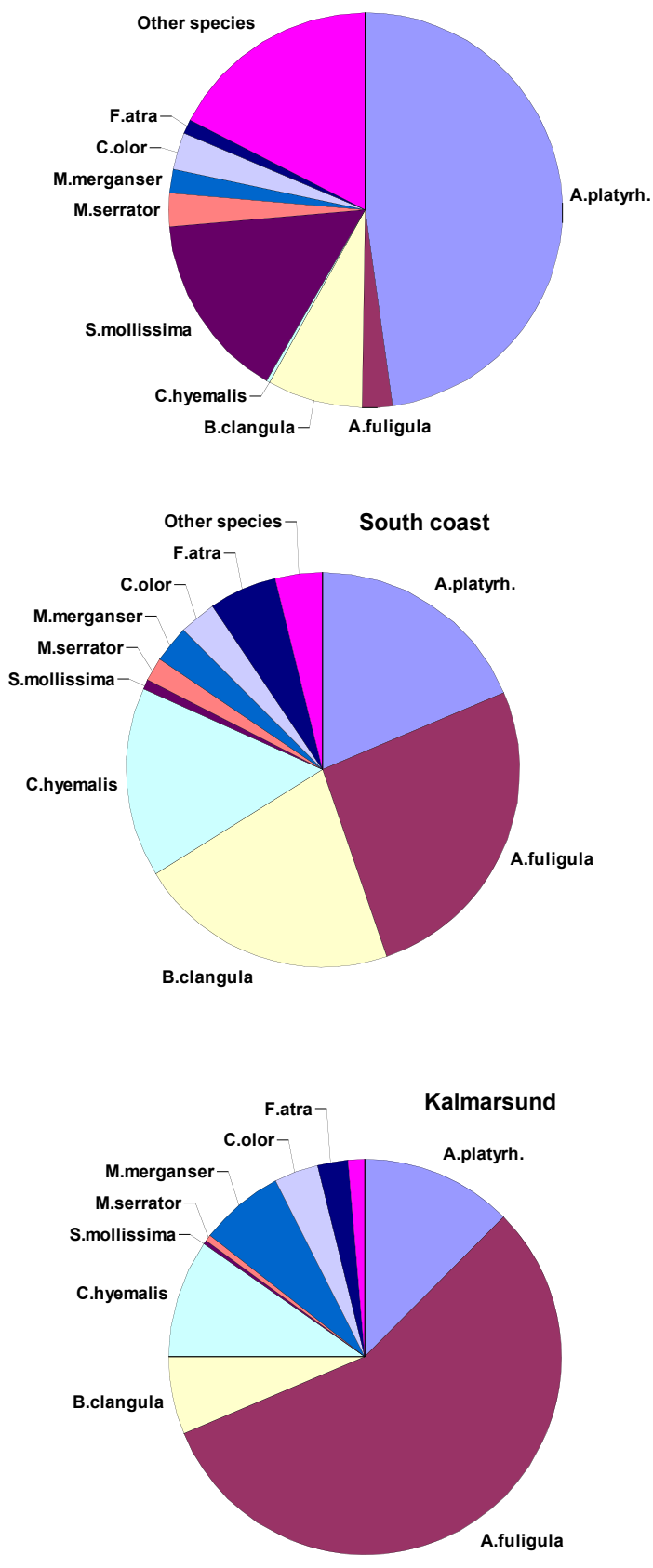

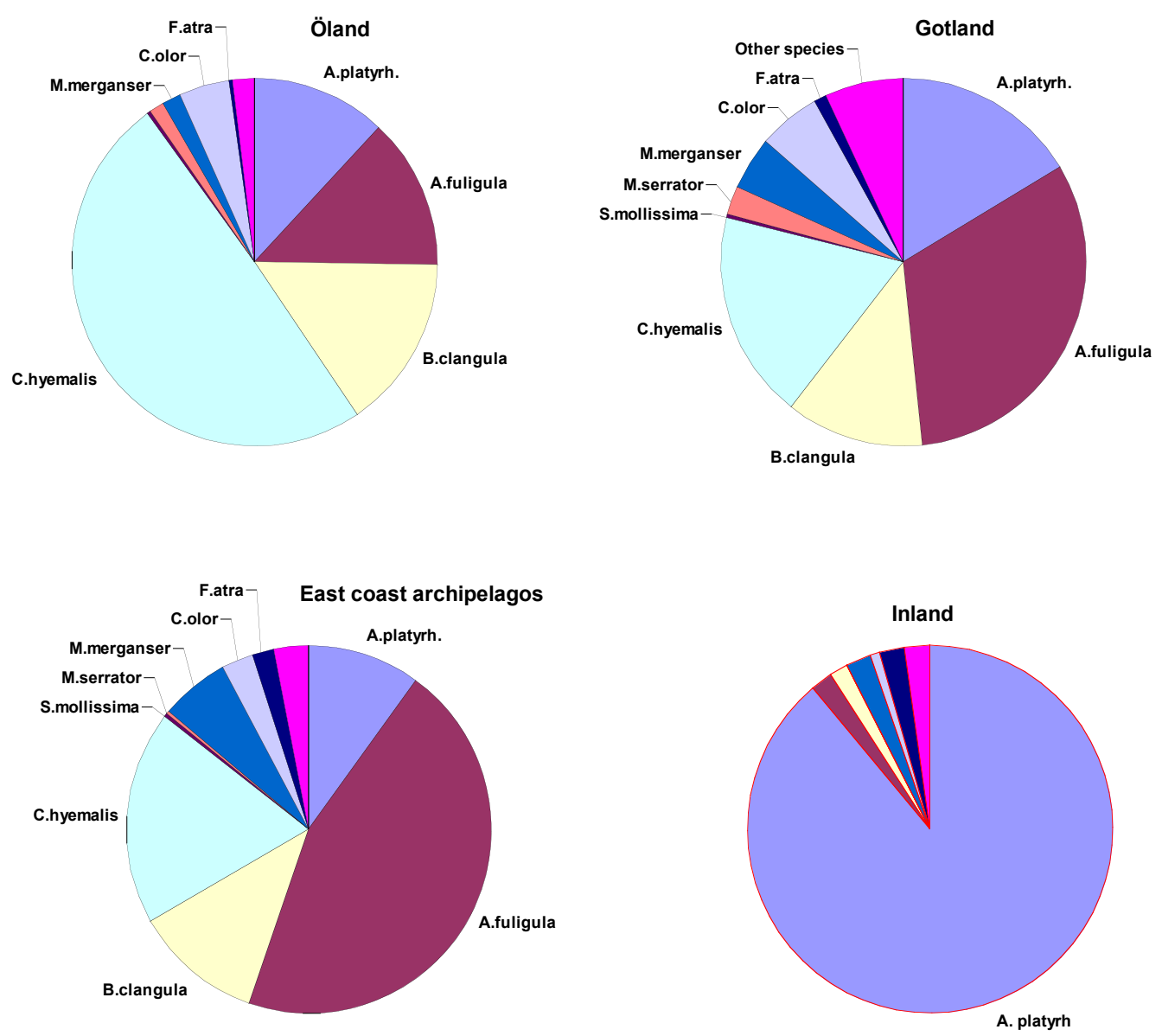

Figure 7. The percentage composition of the wintering waterbird communities in different regions of the Swedish coast (Figure 1) and in the inland.

Sjöfågelbeståndets procentuella sammanställning efter olika avsnitt av den svenska kusten (Figur 1) och $i$ inlandet.

cold weather drives many waterbirds to the south.

The most dominant species of the inshore waters in the archipelago areas of the Baltic Sea from Blekinge in the south to Väddö in the north was the Tufted Duck. In the south, in Blekinge, it constituted about $75 \%$ of all waterbirds counted, whereas its share of the total population was about $50 \%$ in Kalmarsund and in the east coast archipelagos north of Kalmarsund. Four other species were common in Blekinge in addition to the Tufted Duck: Mallard, Goldeneye, Coot and Mute Swan. Even if the Long-tailed duck was a common species in the neighbouring Hanöbukten, it was not seen in any larger numbers in the Blekinge archipelago.
In Kalmarsund and the archipelagos further to the north Long-tailed Ducks were common in the outer regions. In the inner parts, the Mallard, Goldeneye and Goosander Mergus merganser were common in addition to the Tufted Duck.

Due to the topography of the island of Öland, the offshore Long-tailed Ducks will come relatively close to shore and will be included in a quite high percentage in the counts presented here (even if these numbers are only a small fraction of those occurring offshore. In addition to the Longtailed Duck, Mallard, Tufted Duck and Goldeneye formed important portions of the duck community of Öland. 
Table 5. Total numbers of wintering waterbirds counted in the east coast archipelagos from the northern part of the Kalmar county to Väddö in the Stockholm county (regions H, M, N and O in Fig. 1) at surveys covering the inshore areas of the entire region. Species marked with grey for 1971 were not counted during that year. The outer areas used by Clangula hyemalis were not covered in 2004.

Antalet räknade övervintrande sjöfåglar $i$ ostkustskärgårdarna från norra Kalmar län till Väddö (regionerna H, M, N och O I Fig. 1) vid inventeringar som täckte hela regionen. Arter markerade grått 1971 inventerades ej detta år. De yttre alfågelområdena inventerades inte 2004.

\begin{tabular}{lrrrr}
\hline Species Art & 1971 & 1972 & 1973 & 2004 \\
\hline Anas platyrhynchos & 4960 & 7260 & 6620 & 9090 \\
Anas crecca & 0 & 0 & 0 & 3 \\
Anas penelope & 0 & 0 & 0 & 1 \\
Anas strepera & 0 & 0 & 0 & 1 \\
Anas acuta & 0 & 0 & 0 & 0 \\
Aythya marila & 0 & 3 & 0 & 289 \\
Aythya fuligula & 15395 & 16662 & 17285 & 78622 \\
Aythya ferina & 0 & 52 & 41 & 157 \\
Bucephala clangula & 1010 & 2140 & 2380 & 26325 \\
Clangula hyemalis & 32100 & 32120 & 28800 & \\
Polysticta stelleri & 3 & 0 & 1 & 1 \\
Somateria mollissima & 229 & 481 & 336 & 160 \\
Melanitta fusca & 4 & 2 & 71 & 7 \\
Melanitta nigra & 2 & 12 & 41 & 65 \\
Mergus serrator & 110 & 100 & 50 & 57 \\
Mergus merganser & 3590 & 4370 & 4570 & 8425 \\
Mergus albellus & 0 & 0 & 16 & 345 \\
Tadorna tadorna & 0 & 0 & 0 & 0 \\
Cygnus olor & 1477 & 1224 & 1732 & 6584 \\
Cygnus cygnus & 20 & 19 & 19 & 51 \\
Fulica atra & 120 & 1020 & 4950 & 652 \\
Phalacrocorax carbo & 205 & 736 & 476 & 1817 \\
Aredea cinerea & & 1 & 1 & 4 \\
Gavia arctica & & 1 & 0 & 1 \\
Gavia stellata & & 2 & 1 & 2 \\
Podiceps cristatus & & 0 & 4 & 12 \\
Podiceps griseigena & & 0 & 2 & 0 \\
Podiceps auritus & & 0 & 0 & 0 \\
Tachybaptus ruficollis & & 1 & 0 & 2 \\
\hline Total Summa & 59225 & 66206 & 67396 & 138696 \\
\hline & & & &
\end{tabular}

Gotland had a smaller proportion of Long-tailed Ducks in the inshore waters of Öland, the Longtailed ducks staying further out here not being seen from the shore. The inshore areas showed a diverse composition of the wintering waterbird community.

Summing up this section a marked variation was found in the species composition between different coastal regions. Even more marked differences in the composition of the waterfowl community in winter was found between the coast and the inland. The Mallard dominated very markedly inland on all types of water with only smaller numbers of diving ducks counted here (Goldeneye and Goosander). During mild winters with open lakes relatively large numbers of diving ducks could be found on the lakes in southernmost Sweden. 


\section{Species accounts}

The results for the different species are presented separately in this section. The general winter distribution and changes in distribution found over the years, is illustrated by two distribution maps for each major species, representing 1971-1974 and 2004, respectively. Moreover, the national indices for more common species are discussed and analysed together with actual count data from different reference areas (see Figure 3, in the text reference to these areas will be given by their number on the map) to elucidate annual fluctuations regionally and nationally and to analyse for possible trends. For the less common species total counts for the reference areas during 1987-2006 will be presented, these sites being covered fully on an annual basis during these years.

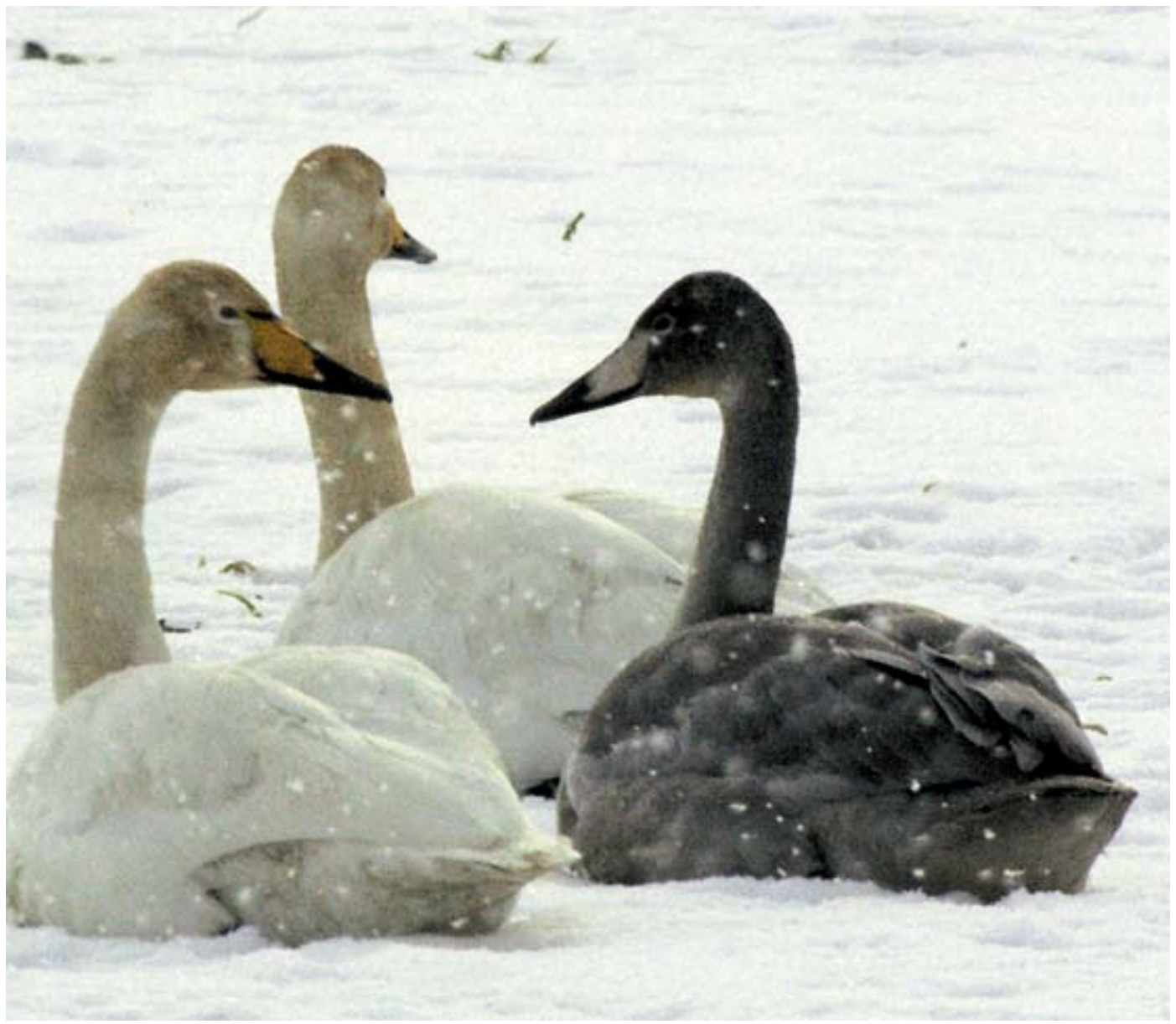




\section{Mallard Anas platyrhynchos}

The national midwinter indices showed a marked and significantly increasing trend (Figure 8). Breaking down the index series, indices for the period 1967-1987 fluctuated around a steady level followed by a marked increase during the later years of the series.

Comparing the two years with more or less complete coverage, the total January population increased from about 68,000 in 1971 to at least 150,000 in 2004 . The two figures are probably minimum estimates. The coverage of the coasts (Table 3-5) was good in both years, but the species was common and much dispersed inland and it is easy to overlook a number of the small flocks of Mallards that are dispersed on a large number of smaller inland localities. In this context it should also be remembered that inland coverage was better in 1971-1974 than in 2004.

The Mallard was widely distributed over southern Sweden, both inland and at the coast (Figure 8). Even if the number of Mallards was much higher at the survey in 2004 then in 1971, the general distribution pattern was very similar in the two years.

Even if the Mallard was spread all along the coasts, it was much more common at the open coasts than in the archipelagos during both country-wide surveys. The flocks in the archipelagos were generally smaller than the flocks along the open coasts. North of the areas covered in the annual censuses (see Figure 8) only small numbers were found along the coast in the areas of the Bothnian sea that had been ice-free in the last few milder winters. On the other hand small numbers of Mallard have been found on open water as far north as Umeå.

The counts in different regions in general showed the same pattern as the national indices, even if there were much more fluctuations in the actual count data from the reference areas than in the more smoothed indices. There was also a lot of variation between different sites (Figure 9, cf. also the appendix for regional totals from the large-scale surveys). Especially the timing of the increase in numbers varied much between the coastal sites. The Kattegat sites $(2,3)$ showed a marked increase in the number of wintering Mallards more or less directly after the cold 1987 winter. After that the counts here mostly showed annual fluctuations again, but on a higher level. There was much variation between years with low counts in the somewhat colder winters. In the Öresund (4-6), on the other hand, the increase was later. Especially in the southern part of the Öresund, in the Ramsaar site Foteviken-Falsterbo(6), numbers showed marked fluctuations between years, mostly related to the ice-cover.

In the Baltic, there was also much variation between different years. The increase in the numbers on the south coast of Scania (7) was late compared to other areas such as Blekinge $(8,9)$. On the other hand there were no so marked increases in the number of Mallards on the Gotland(13) and Kalmar sites $(10,11)$, but the large scale counts for the entire provinces (appendix) showed a doubling of the number of Mallards between the seventies and 1993 and 2004 respectively. Stockholm archipelago also experienced the same development at Muskö (14). The country-wide surveys showed an increase for the archipelagos between the seventies and 2004 (Table 5), but it was not so marked as for other areas.

The Mallard is the dominant waterfowl in inland Sweden in winter, the total population probably being larger than the coastal population in many years. In normal years, open water is mostly avail-

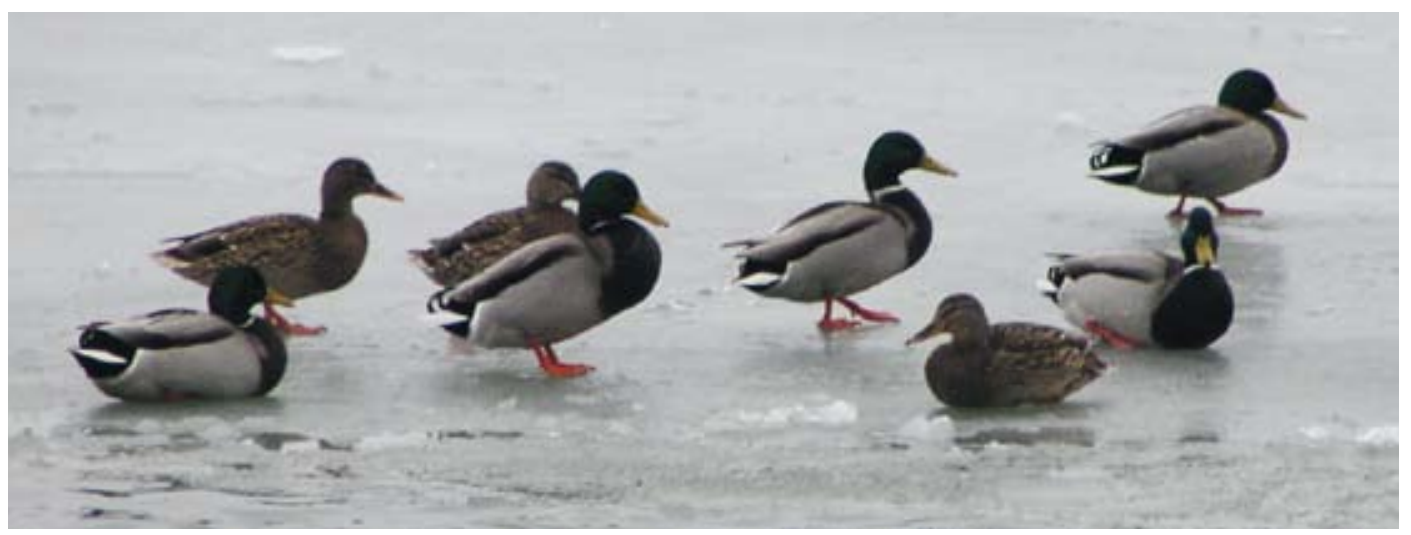



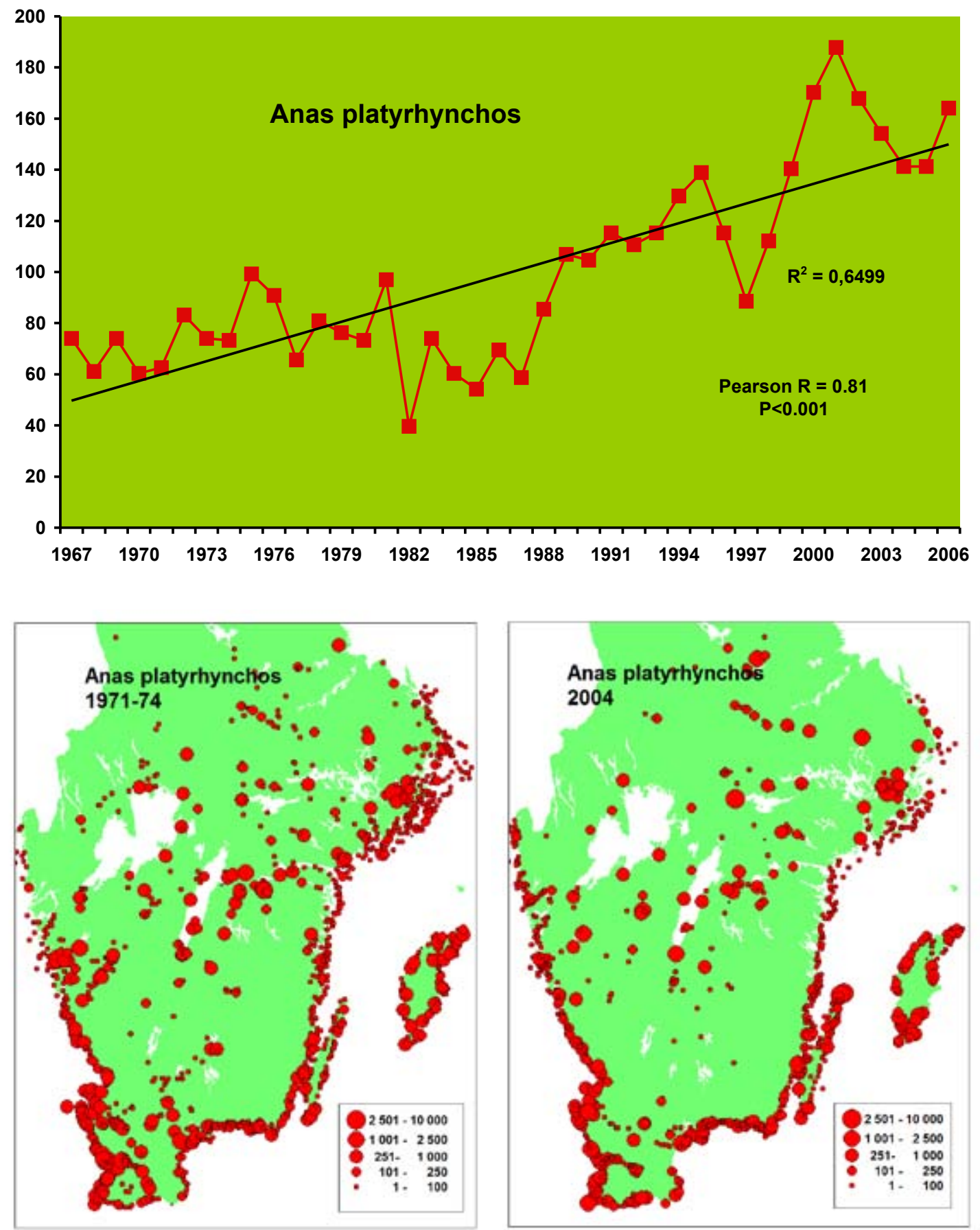

Figure 8. Mallard Anas platyrhynchos. Midwinter population indices and distribution maps.

Gräsand Anas platyrhynchos. Midvinter populationsindex och utbredningskartor. 

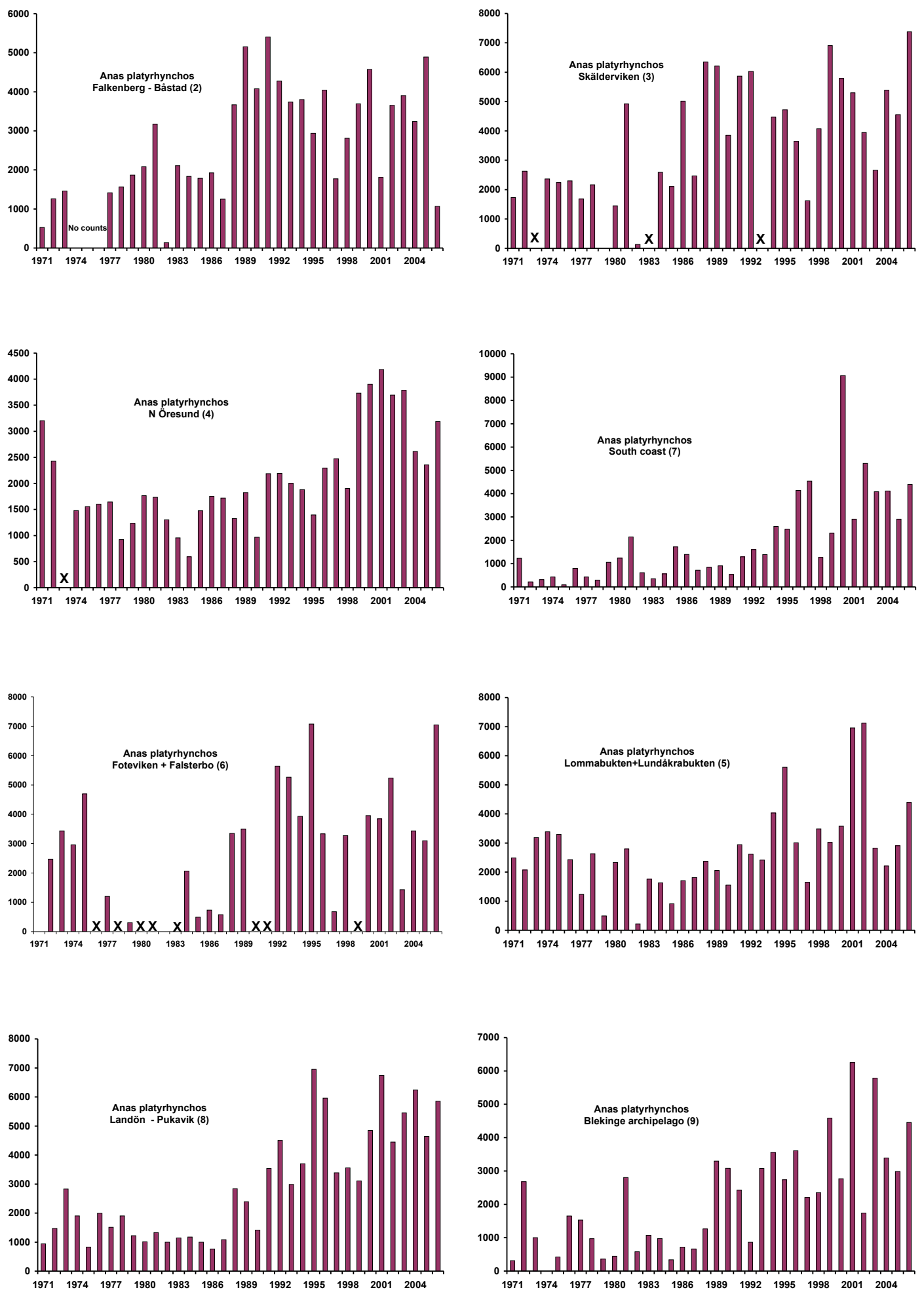

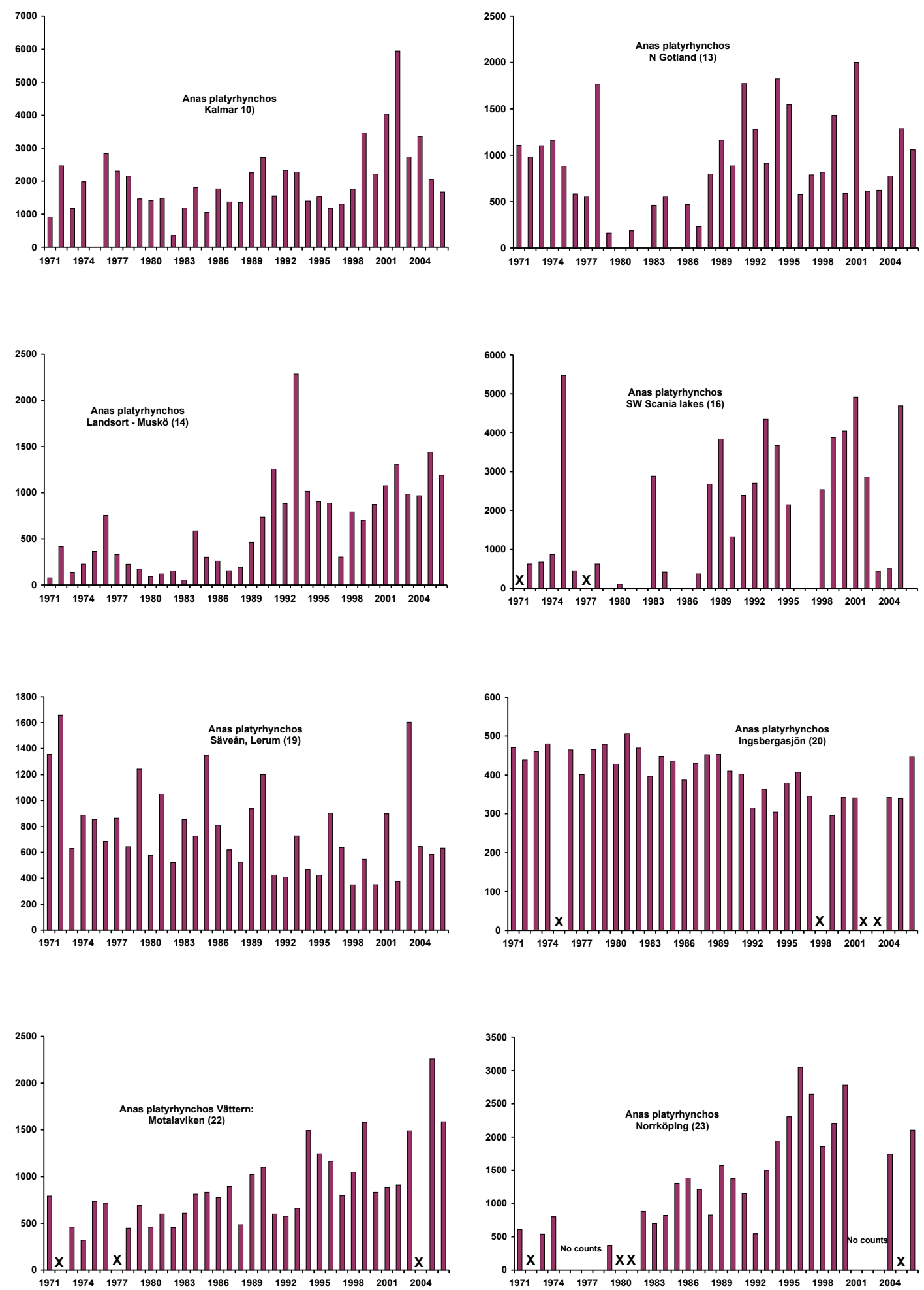

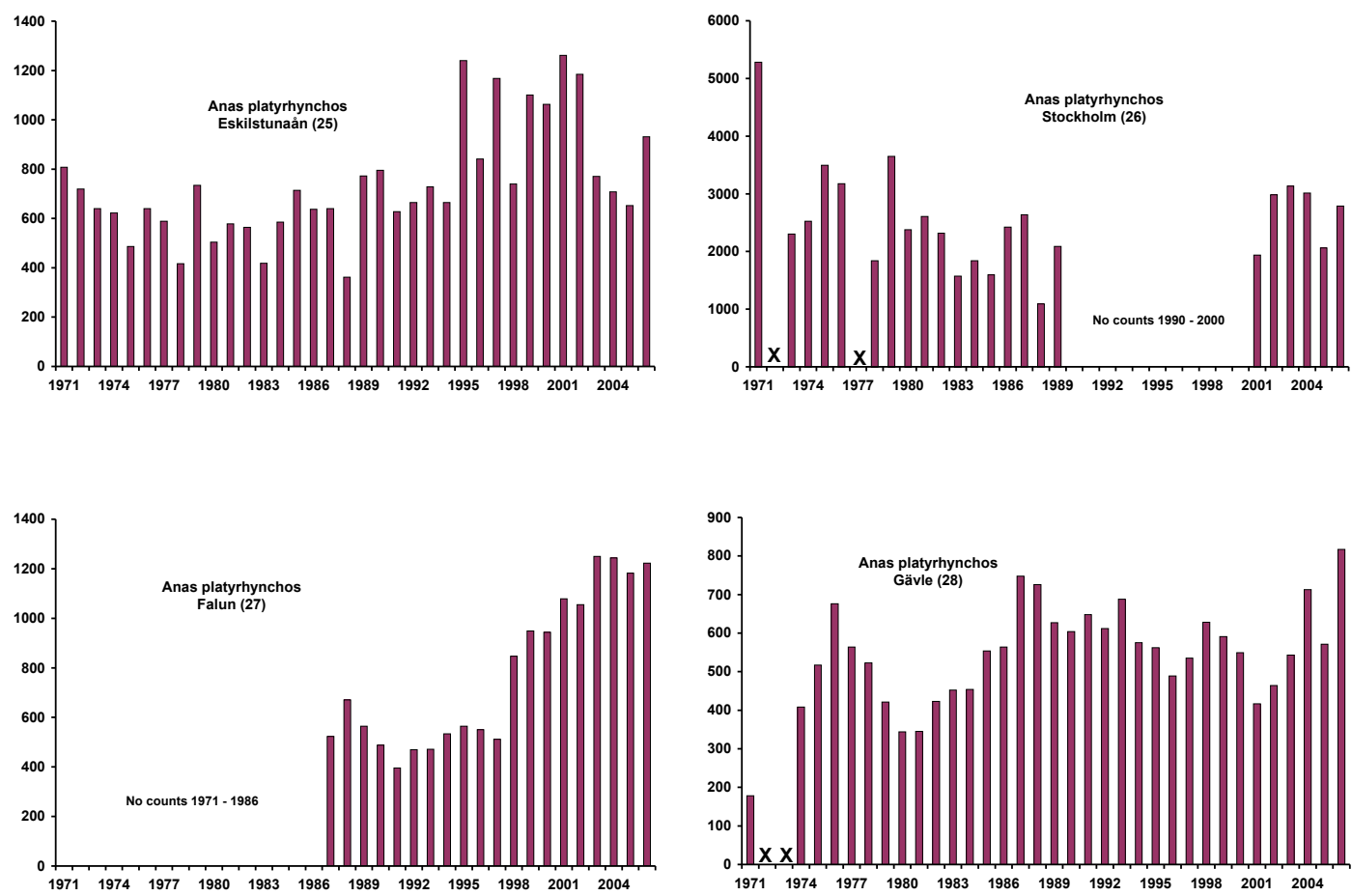

Figure 9. Counts of wintering Mallards Anas platyrhynchos reference areas (Figure 3) in Sweden in January 1971-2006. X= No counts in the area this year.

Räkningar av gräsand Anas platyrhynchos inom olika referensområden (Figure 3) $i$ Sverige januari 1971-2006. X= räkningar saknas detta år.

able in rapidly flowing streams and river outlets in the lakes. The lakes are mostly ice-covered in January except in the southernmost province, Scania, where they have been ice-free at least partly in many winters during the latter half of the survey period and some mild winters in the 1970s. Accordingly the number of Mallards counted on the inland sites especially in southernmost Sweden has varied a lot between different years as exemplified for a group of lakes in SW Scania (Figure 9).

The small rivers in Scania were not included in the annual counts and were mostly covered in the country-wide surveys only. During the years 1970 1974 all duck habitats (inland and coast) were more extensively surveyed in Scania (Nilsson 1975) with about $75 \%$ at the coast and $25 \%$ distributed on urban waters, natural rivers and lakes. There was a clear shift between lakes and small rivers related to the ice-cover, the Mallards wintering on the lakes moving to the small rivers with open water when the lakes were freezing.
The long-term pattern in Mallard numbers wasdifferent in different inland reference areas north of Scania. At Säveån (19) and Ingsbergasjön (20) the long-term pattern was more of a decline but with some peak counts, whereas numbers increased at two river sites a little further to the north: Norrköping (23) and Eskilstuna (25). On the large Lake Vättern at Motala (22), where open water was available in most winters, a marked increase started after the last cold winter 1987. It may be noted that there was no clear trend in the number of Mallards wintering in the City of Stockholm (26), one of the larger wintering sites for Mallard in this part of Sweden. The two most northern urban sites Falun (27) and Gävle (28) showed markedly different patterns. At the river in the inland site Falun, numbers were relatively steady for the eleven year period 1987-1997, then there was a marked increase, whereas the river site in the more coastal city of Gävle had a rather constant number of wintering Mallards. 


\section{Wigeon Anas penelope}

When the counts started, the Wigeon was a sparse bird, reported in single individuals except for the mildest winters, when small flocks were found. These observations came from most parts of south Sweden but with a concentration to the southern part of the Öresund (Figure 10). This situation was prevailing until 1991, when a marked increase started (Figure 11), numbers reaching peak counts

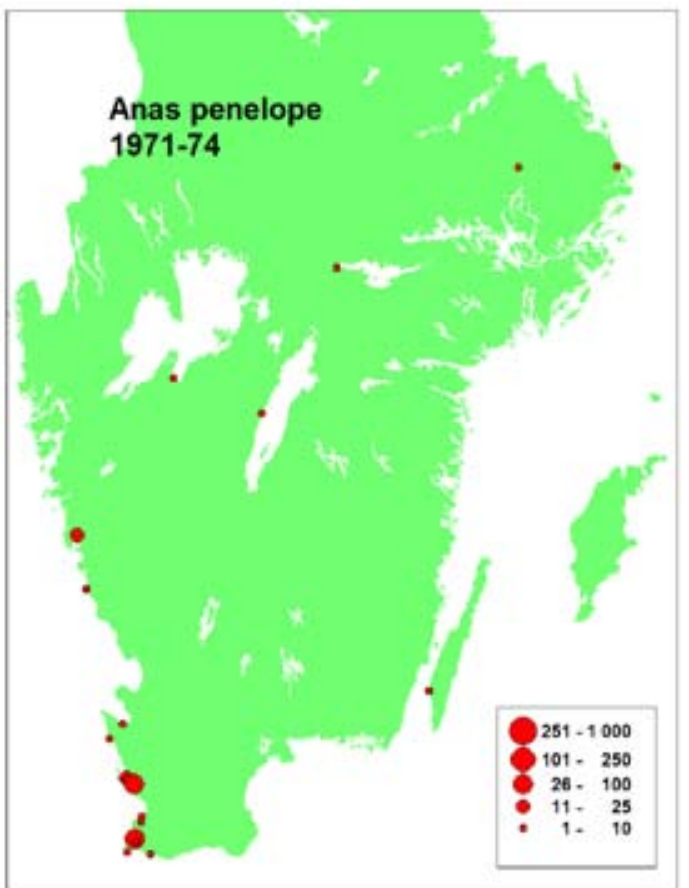

Figure 10. Wigeon Anas Penelope. Midwinter distribution maps. Bläsand Anas Penelope. Utbredningskartor för midvintern.

Figure 11. Annual total counts of Wigeon Anas penelope on all coastal reference areas (Figure 3) in Sweden in January 1987-2006.

Arliga totalsummor av bläsand Anas penelope på samtliga referensområden vid kusterna av Sverige (Figur 3) januari 1987-2006. between 8000 and 9000 individuals during the most recent winters. There was some variation between years related to the hardness of the winter, but in later years large flocks of Wigeons remained in the south of Sweden even during ice-periods. The flocks were still concentrated to the southwestern part of the country, but spread in the Öresund region, and in 2004 large flocks were found in suitable habitats all the way from Falsterbo in the southwest to Skälderviken.

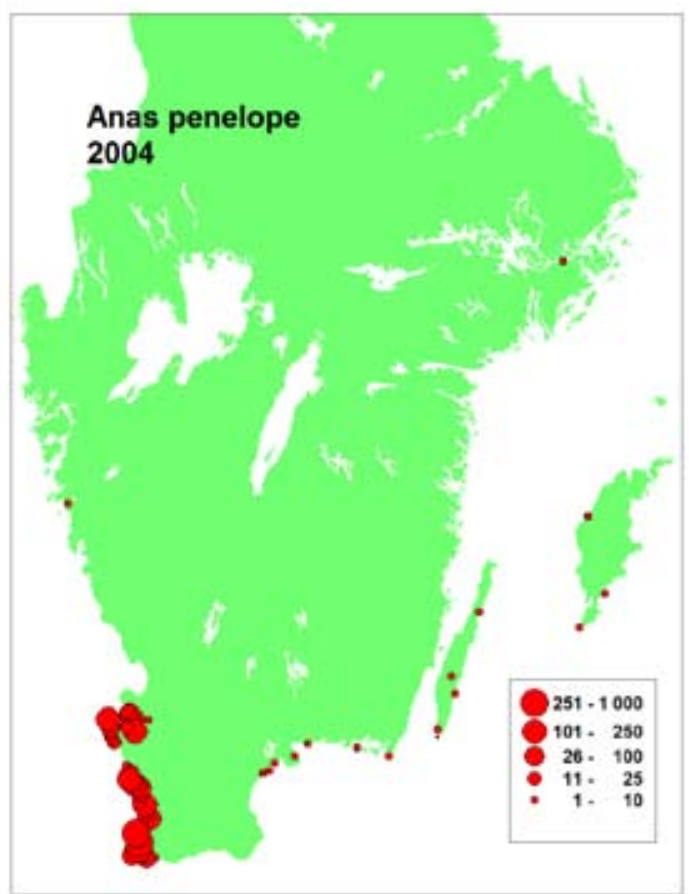

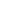




\section{Scaup Aythya marila}

The Scaup was a regular wintering species in varying numbers, being found mainly at the coasts of Scania, Blekinge, Öland and Gotland (Figure 12), but sometimes larger flocks were found in other coastal areas. Normally most Scaups werw counted in small numbers in the large flocks of Tufted Ducks along the coasts, but sometimes large pure flocks were found, especially on Gotland. The occurrence of Scaups was rather irregular but there were also some more traditional wintering areas, where Scaups were to be found every winter, although in varying numbers.

At the country-wide surveys in 1971 and 2004, the total numbers of Scaups found were 1100 and 3200 , but higher numbers have been found in some regions on other occasions, thus close to 7000 were counted on Gotland in 1993 (appendix). The total numbers of Scaups counted in the reference areas showed marked variation between years (Figure 13) with more than 5000 counted in two years in the 1990s and with lower counts more recently.

There was also much variation between years for the three most important sites (Figure 14). In the

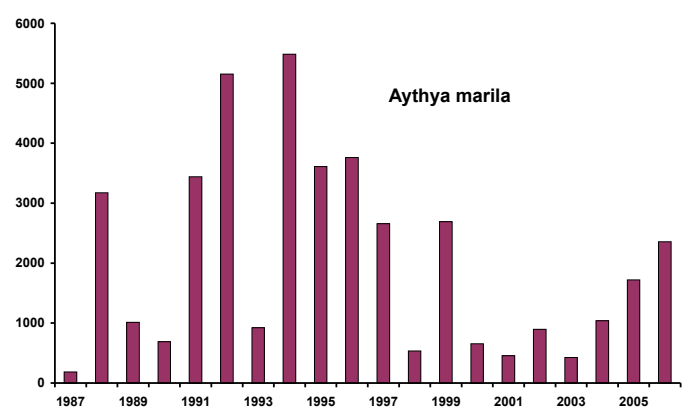

Figure 13. Annual total counts of Scaup Aythya marila on all coastal reference areas (Figure 3) in Sweden in January 1987-2006.

Arliga totalsummor av bergand Aythya marila på samtliga referensområden vid kusterna av Sverige (Figur 3) januari 1987-2006.

reference area on Gotland (13) there was a marked variation between years but peaks were higher and higher until 1999, after which only smaller numbers were counted. On the sites in the Öresund $(5,6)$ and Blekinge $(8,9)$ counts were low until the 1990 s with much higher peak counts in later years.
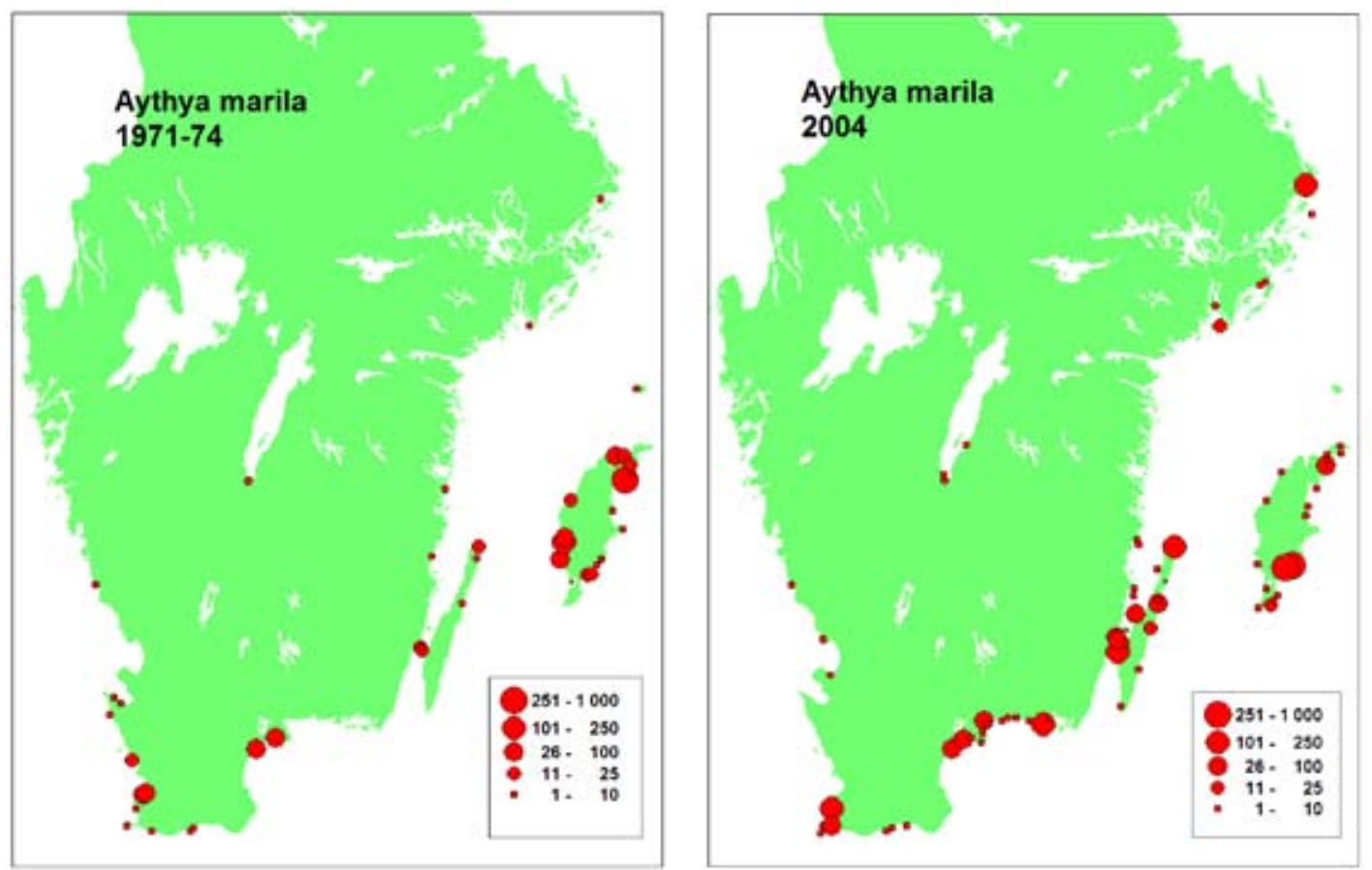

Figure 12. Scaup Aythya marila. Midwinter distribution maps. Bergand Aythya marila. Utbredningskartor för midvintern. 

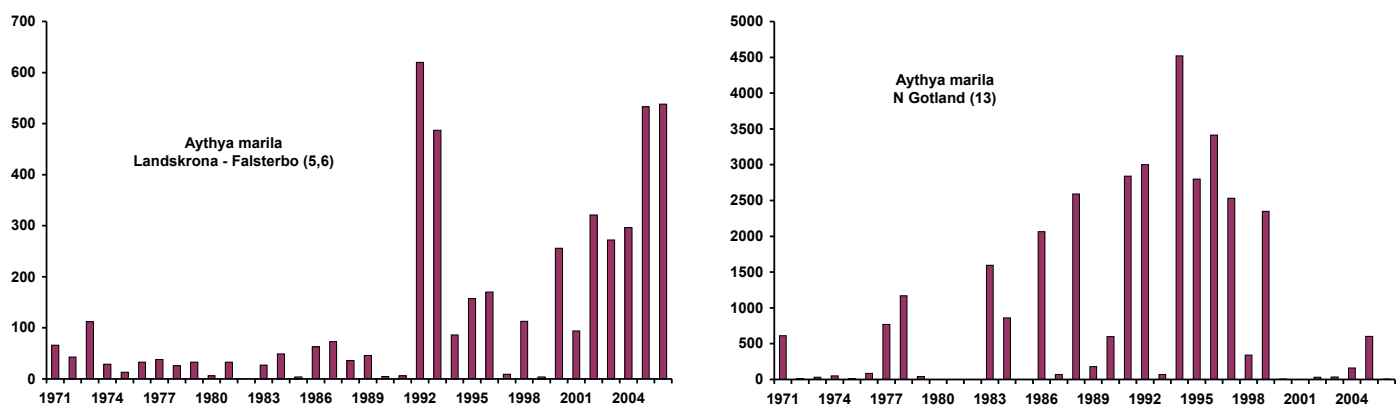

Figure 14. Counts of wintering Scaup Aythya marila in coastal reference areas (Figure 3) in Sweden in January 19712006. $\mathrm{X}=$ No counts in the area this year.

Räkningar av bergand Aythya marila inom olika referensområden vid kusterna (Figur 3) i Sverige januari 1971-2006. X = räkningar saknas detta år.
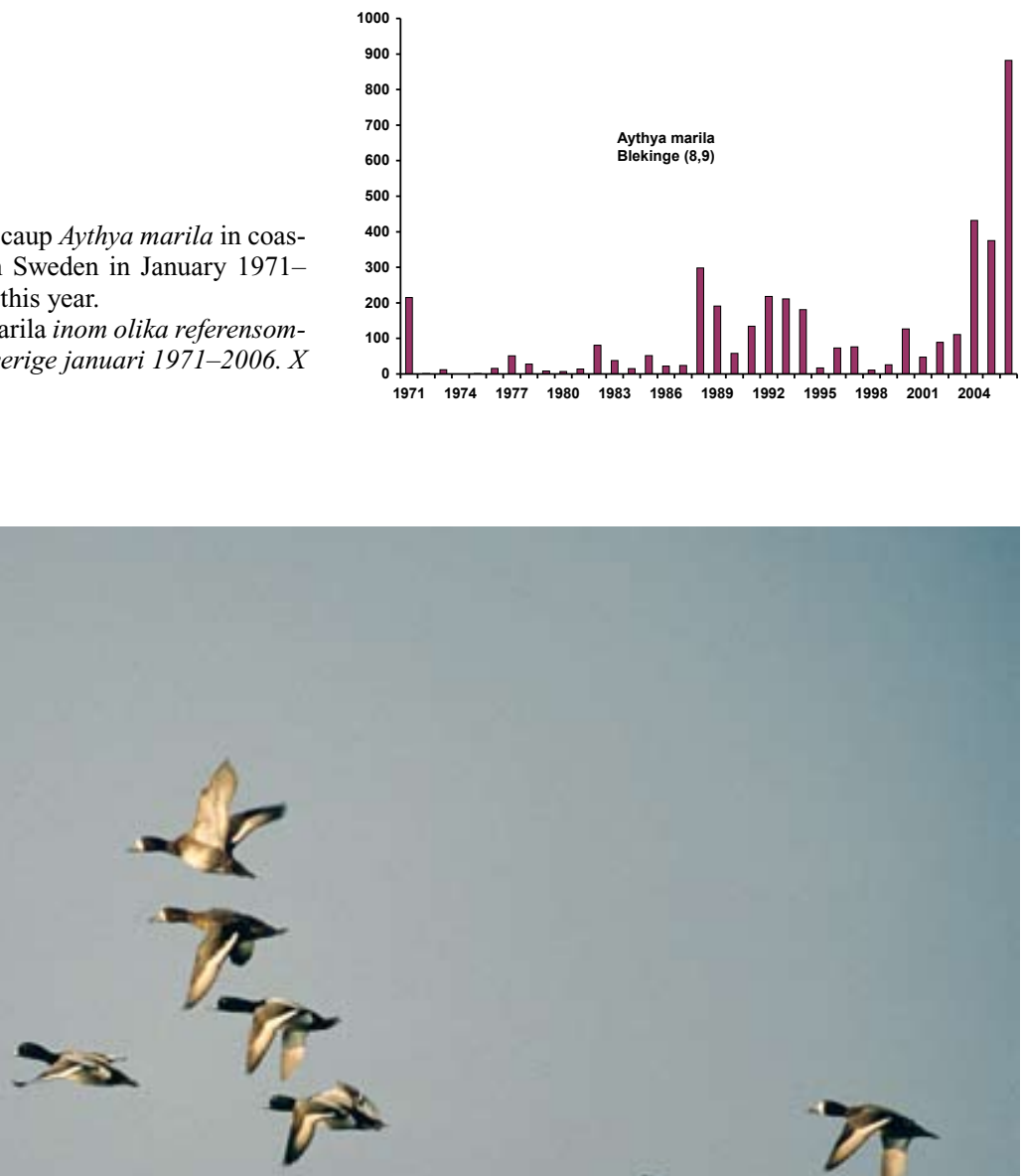


\section{Tufted Duck Aythya fuligula}

The national indices showed a marked increase, the index for 2006 being almost four times higher than that for the start year 1967 (Figure 15). Even if the overall trend is highly significant, the changes can more correctly be described as fluctuations around a steady or slightly increasing level from 1967 to 1991 followed by a very marked increase (as was the case for the Mallard), coinciding with the onset of milder winters in Sweden.

The Tufted Duck was the most common duck species in the country-wide survey in 2004 (offshore areas not counted) with an estimated winter population of 230,000. In January 1971, the Mallard was more common, but at the coast the Tufted Duck was the commonest inshore species with an estimated population at that time of 54,000 at that time. The total number of Tufted Ducks in inland Sweden was low, less than 1000 in the 1970s, when coverage inland was more extensive than in later years. The situation was similar in 2004, but in some of the milder winters (without country-wide surveys) several thousand Tufted Ducks have been counted on the ice-free lakes in Scania.

The Tufted Duck is a typical species of the Baltic coast with only small numbers found on the west coast, the exception being the southern part of Öresund (Figure 15). When feeding, it is a nocturnal species in most areas (Nilsson 1972), roosting in calm places during the day. Along the open coasts it is mainly found in sheltered places such as harbours or ponds close to the shore-line during the day. In the archipelagos it is mainly found in the inner and middle zones as long as these are ice-free, using sheltered bays as day-time roosts. Then the ducks move out to open water and do normally not leave the area until they are forced by the ice.

Comparing the two country-wide surveys illustrated in Figure 15, the general distribution patterns for the two winters were similar, but there were also differences in some areas. In the Öresund only few Tufted Ducks were counted in the northern part in 2004 compared to 1971 . The Baltic is the main stronghold for the species (Blekinge, Kalmarsund, Öland, Gotland and the northern archipelagos) and the distribution in the two years was more or less the same, but most flocks were larger in 2004. Moreover, the gap in the distribution of Tufted Ducks between the archipelagos of Södermanland and the Kalmarsund region was not so marked in 2004 as it was in 1971-1974.

The counts in the reference areas not unexpect-

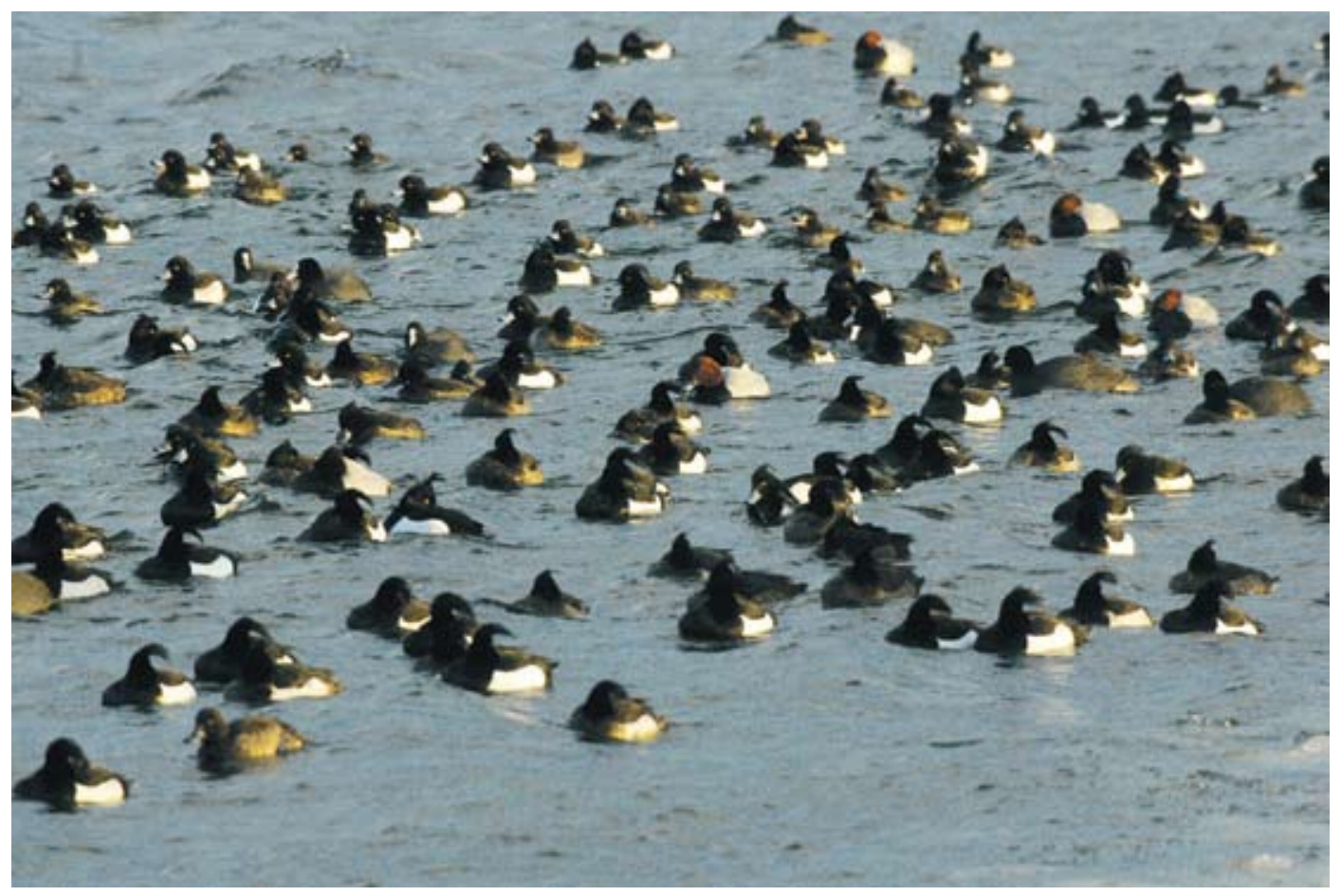



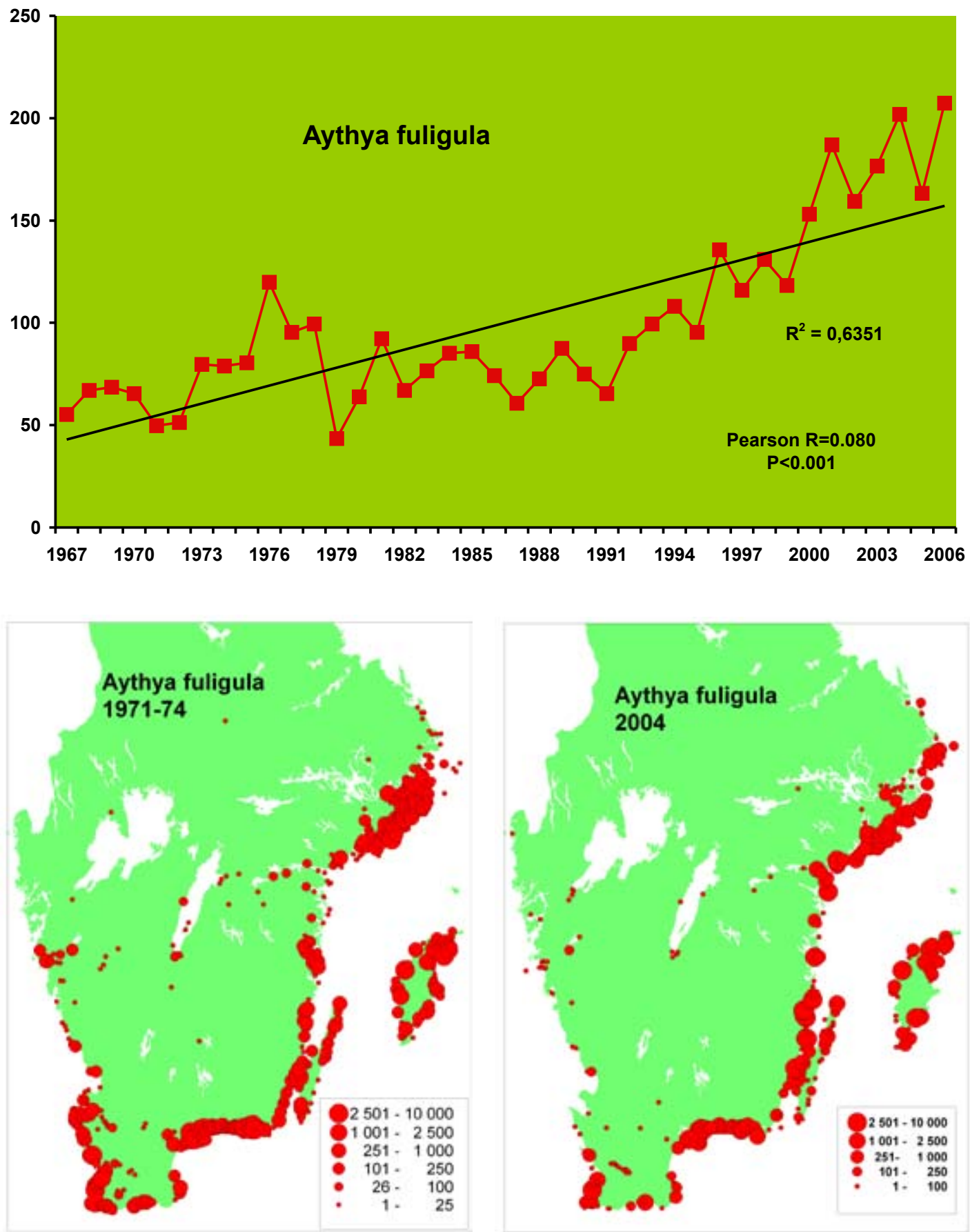

Figure 15. Tufted Duck Aythya fuligula. Midwinter population indices and distribution maps.

Vigg Aythya fuligula. Populationsindex och utbredningskartor för midvintern. 

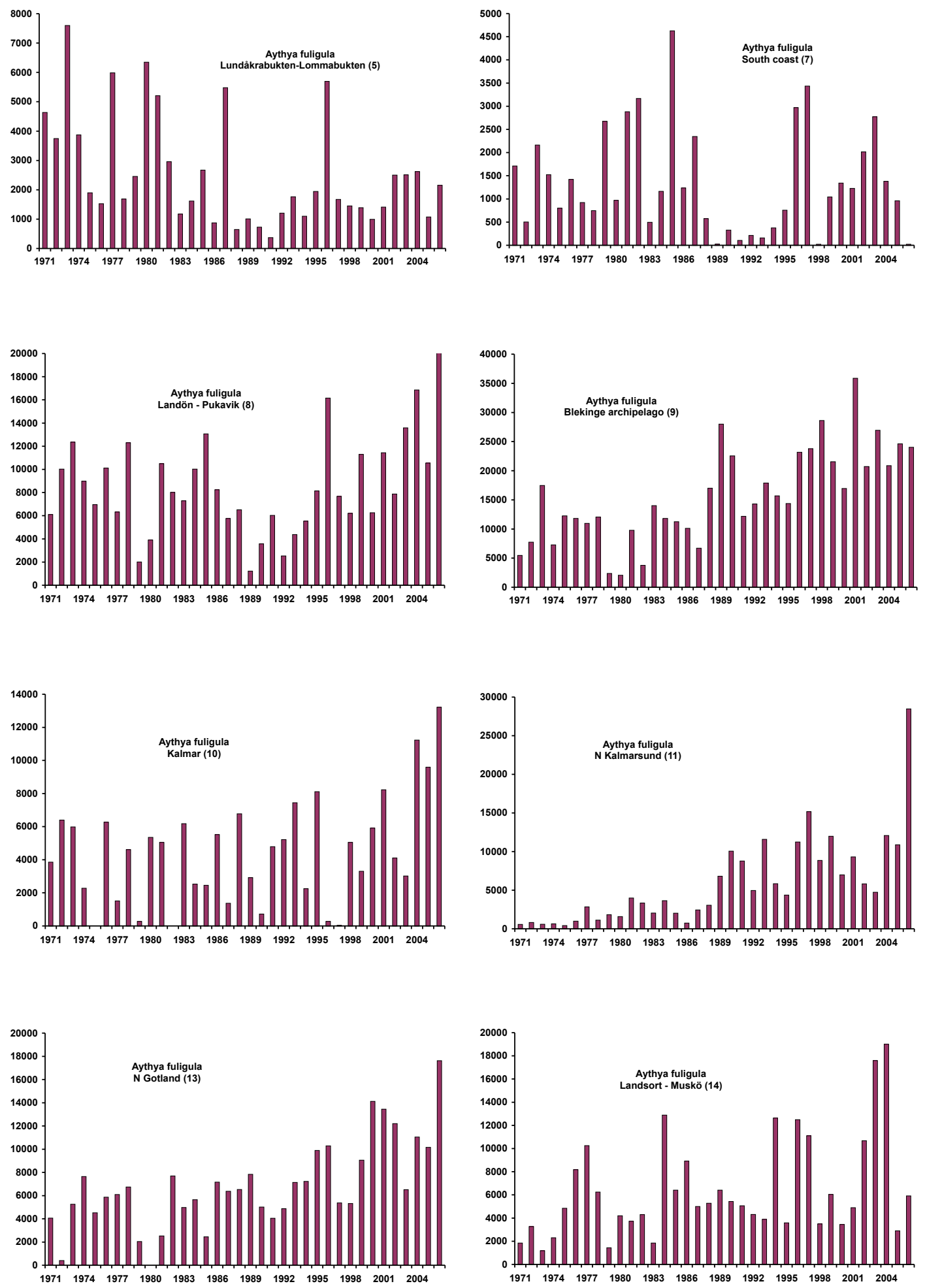
edly showed a more varying picture (Figure 16). It is clear that there was a marked increase of Tufted Ducks in all Baltic areas with the exception of Scania. The overall totals for the southern Baltic areas increased from 36,000-66,000 in the 1970s to 146,000 in 2004 (Table 4), and in the Baltic archipelagos the number of Tufted Ducks increased from 16,000-17,000 to 78,000.

During the country-wide survey in 2004, the counts for the Öresund region and the south coast (Falsterbo-Hanö) were unusually high (appendix) whereas the annual counts for the reference areas in Öresund (Lundåkrabukten + Lommabukten, 5) and the south coast of Scania (7) show lower counts in the latter part of the forty year period than during the first half of the period (Figure 16) but there was a marked variation between years.

Some high counts in Scania could be related to cold periods with sea ice further north along the Baltic coast, but during the coldest periods the Öresund was also freezing. The graph for the south coast of Scania (Figure 16) gives the impression that the species was at least as common during the first part of the count period as later. The peaks here between 1979 and 1987 were related to cold ice winters, whereas the peaks in 1996 and 1997 occurred during shorter cold periods.

For all reference areas in the Baltic proper, the counts showed an increase over the years, but there was much variation between years, which could be related to variation in the ice coverage of important feeding areas. In the province of Blekinge (areas 8, 9), large numbers of Tufted Ducks were counted in all years. In the main archipelagos of Blekinge (9) numbers fluctuated around a steady level between 7000 and 12000 for most years before 1988, numbers in the later years being considerably higher, normally above 20000 birds. There were some ice winters with lower numbers in Blekinge, but in most cold winters there were some open areas in the outer archipelago with large concentrations of Tufted Ducks.

The Kalmarsund areas $(10,11)$ and northern Gotland (13) showed a similar picture mostly with fluctuations before the 1990s followed by marked increases. In the Kalmarsund marked fluctuations related to the ice-situation were found. Large flocks often occurred at Kalmar (10) but they disappeared during cold periods, when the entire area was frozen. In the shallow archipelagos of northern Kalmarsund (11), the number of wintering Tufted Ducks was low before 1989, when most years had rather much ice in January. Later, larger flocks were regular. In the latter region open water close to a nuclear power plant influenced the distribution of Tufted Ducks in cold winters.

In the northernmost reference area considered here, Landsort-Muskö (14), between 3000 and 6000 Tufted Ducks were counted in most years but much higher counts were obtained for some winters with good availability of open water.

Figure 16. Counts of Tufted Ducks Aythya fuligula in coastal reference areas (Figure 4) in Sweden in January 1971-2006. $\mathrm{X}=$ No counts in the area this year.

Räkningar av vigg Aythya fuligula inom olika referensområden vid kusterna (Figur 4) i Sverige januari 1971-2006. X= räkningar saknas detta år. 


\section{Pochard Aythya ferina}

The national indices for the Pochard showed a very marked increase (Figure 17). Low indices were found during most of the seventies, but then they increased, the increase starting earlier than in Mallards and Tufted Ducks. The Pochard was regularly seen in small numbers in the wintering flocks of Tufted Ducks in south Sweden, mainly at the coasts, but also, mostly in single individuals, inland (Figure 17). At the country-wide surveys only about 100 were found in 1971, whereas 2750 were counted in 2004.

The majority of the wintering Pochards were found in the Blekinge archipelago $(8,9)$, where between 1000 and 1900 Pochards wintered in the latter half of the counting period (Figure 18). Pochards were nearly absent from Blekinge during the cold winters of 1979, 1982 and 1987, whereas close to 600 remained in 1985 . In contrast to other parts of Sweden relatively large pure flocks were found in this southern archipelago.

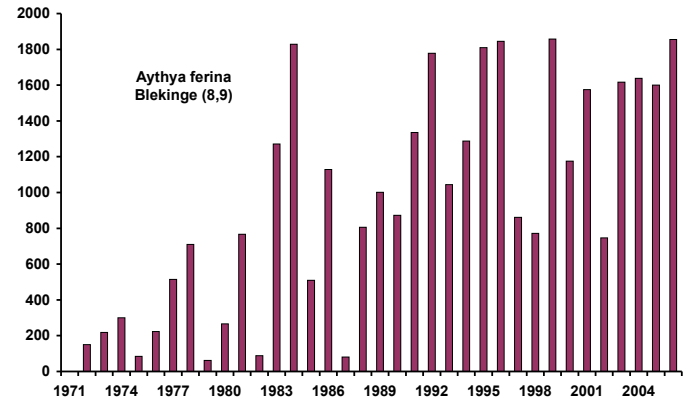

Figure 18. Counts of Pochard Aythya ferina in the reference area 8 and 9 Blekinge archipelago (Figure 3) in Sweden in January 1971-2006.

Räkningar av brunänder inom referensområdena $8+9$ Blekinge skärgård (Figure 3) i Sverige januari 1971-2006.

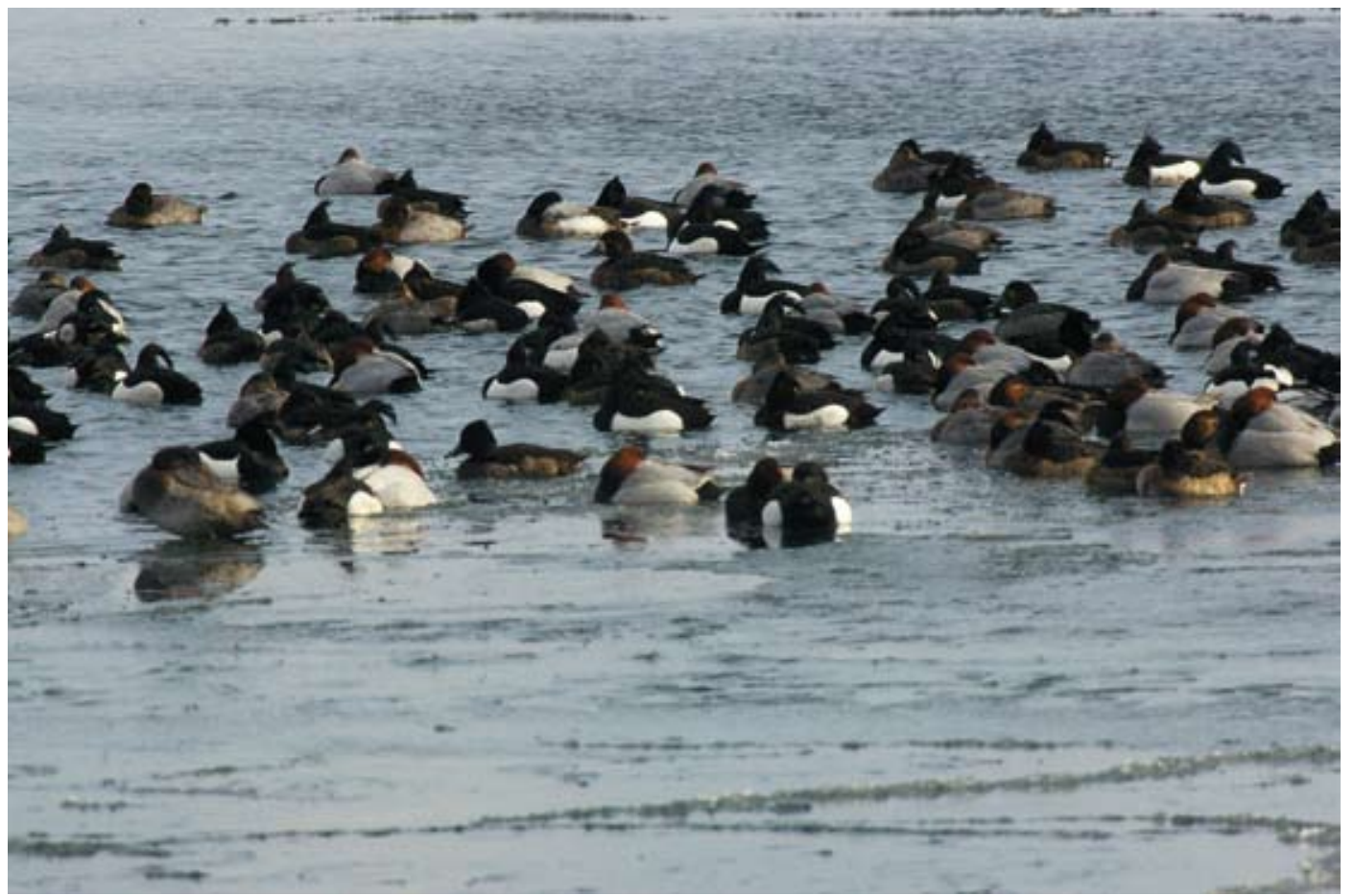



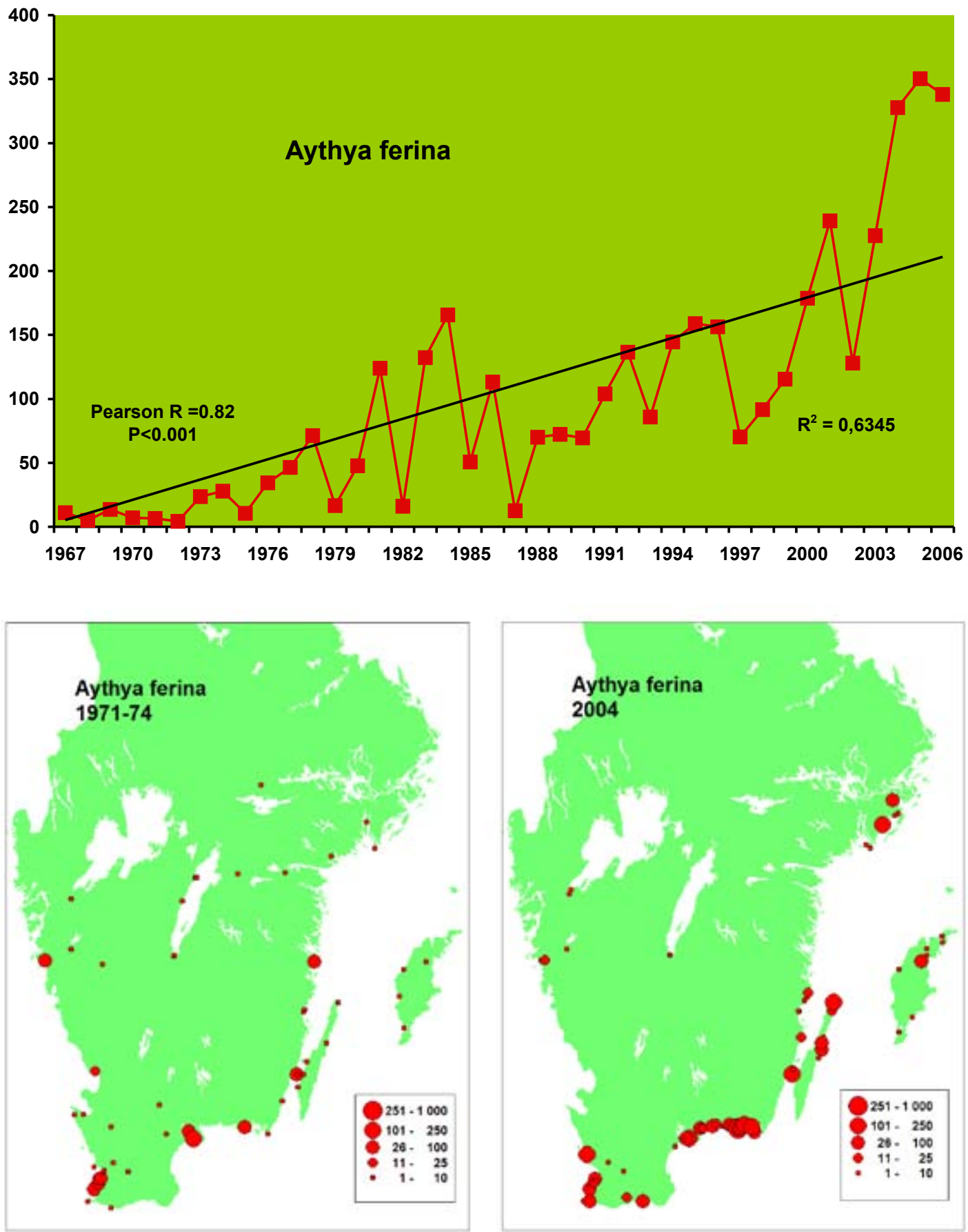

Figure 17. Pochard Aythya ferina. Midwinter population indices and distribution maps. Brunand Aythya ferina. Populationsindex och utbredningskartor för midvintern. 


\section{Goldeneye Bucephala clangula}

The national midwinter indices for the Goldeneye showed a highly significant increase over the entire counting period (Figure 19). In contrast to the Mallard and the Tufted Duck, the increase started already from the first years of counts and it is not possible to split the time-series into periods with significantly different trends, even if there were some years with decreasing indices between 1988 and 1994.

The Goldeneye was the second commonest waterbird in the inshore coastal waters after the Tufted Duck. It was distributed with flocks all along the coast both on the marine west coast and in the brackish Baltic areas (Figure 19). The Goldeneye showed no clear preference for either open coast or archipelago areas. In the most recent (mild) winters the Goldeneye also wintered in relatively high numbers in coastal areas of the Baltic north of those shown on the map and normally not included in the counts (these northerly areas were formerly ice-covered in January).

At the two country-wide surveys the estimated wintering population was 18,800 in 1971 and 75,000 in 2004. This latter total includes an estimate for the northern coastal areas (i. e. the coasts of the province of Gästrikland and Hälsingland (see above), Axbrink 2004) and for inland areas. The estimate of the number of Goldeneyes on inland sites is somewhat uncertain as the species occurs widespread in small numbers on a very large numbers of sites on streams and similar habitats. In 1971-1973, when coverage of the smaller inland waters was extensive 1100-1350 Goldeneyes were found inland. During the later mild winters numbers counted on the index sites was higher than this, so it is esti- mated that the wintering inland population in 2004 was a few thousand Goldeneyes.

The counts in the reference areas (Figure 20) showed marked differences between different parts of the country. Unfortunately annual counts are only available for one larger continuous area in the west coast archipelagos of Bohuslän (although there are several smaller sites from the province included in the index calculations). Counts started in the Gothenburg southern archipelago (1) in 1989 and there has been an almost threefold increase in wintering numbers of Goldeneyes here since then. In the country-wide surveys (Table 3, appendix), there were relatively small changes between 1971 and 1987-1989, but then numbers in the west coast archipelagos of Bohuslän increased from about 2000-3000 to more than 13,000 in 2004. In Kattegat and north-west Scania (2-4) there was no increase, in north-west Scania there was a decrease initially, followed by moderate fluctuations around a steady level. Further south in the Öresund $(5,6)$, the first period of counts had markedly lower numbers than the later period. In the shallow areas in the southern parts of the Öresund the numbers varied much in relation to the ice cover of the area.

In the Baltic, most areas showed increases in the number of wintering Goldeneyes, but numbers on the south coast (7) can more be characterized as fluctuations around a steady level with some peaks although the level was higher in the latter part of the counting period. Unfortunately only one area was available in the Stockholm archipelago, Landsort-Muskö (14). Here no clear trend was found but a number of years of the last ten years of counts showed appreciably higher totals than former years. This variation in the occurrence of high counts was probably related to the ice-situation locally.

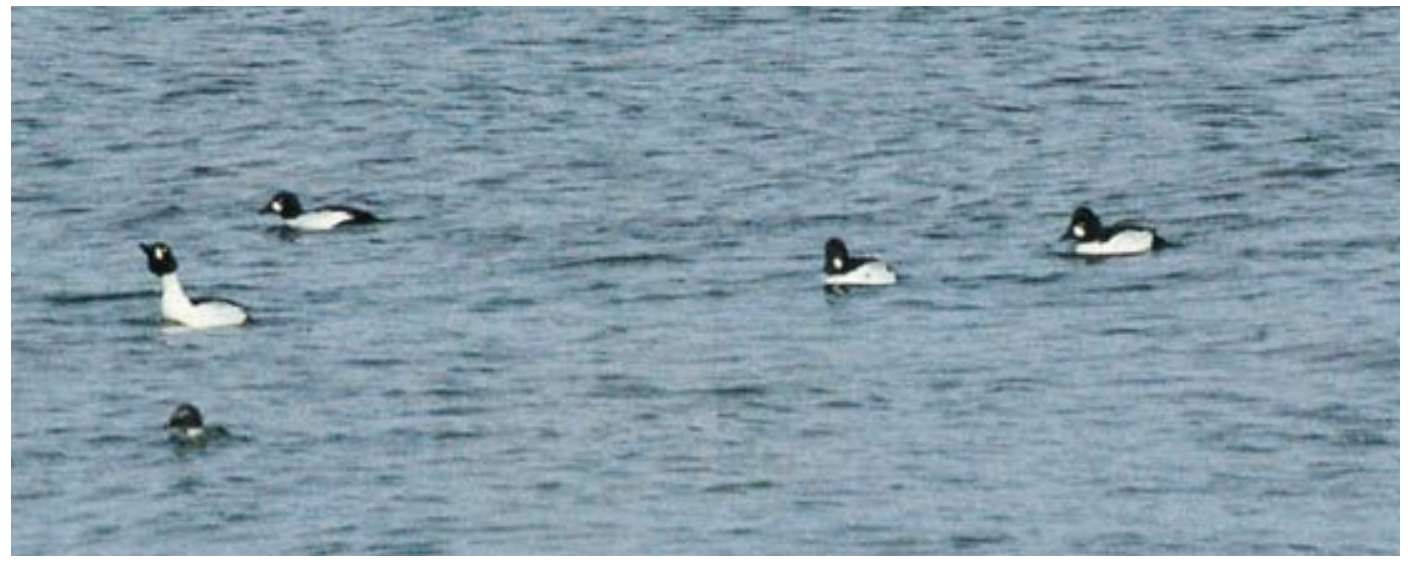



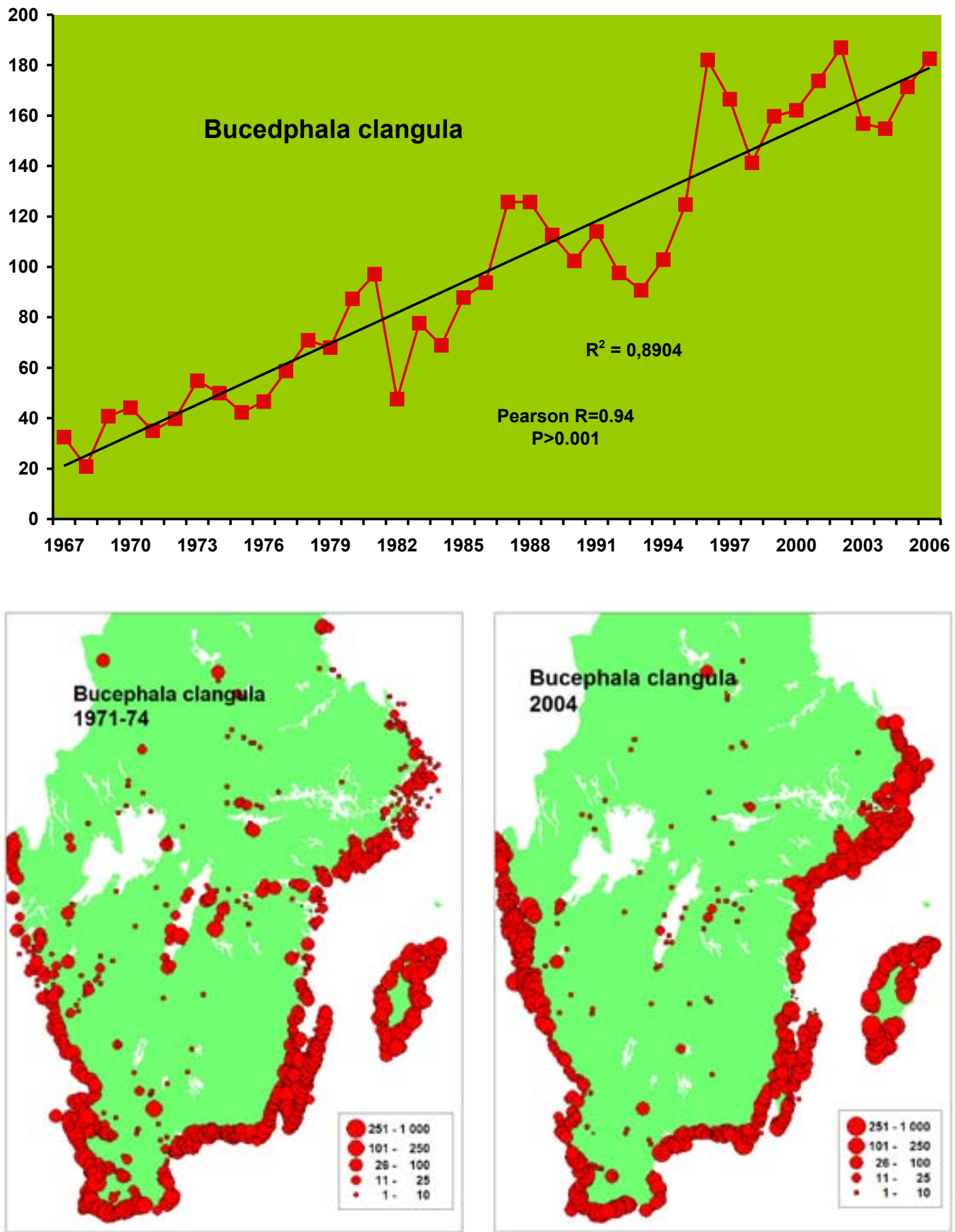

Figure 19. Goldeneye Bucephala clangula. Midwinter population indices and distribution maps.

Knipa Bucephala clangula. Populationsindex och utbredningskartor för midvintern. 

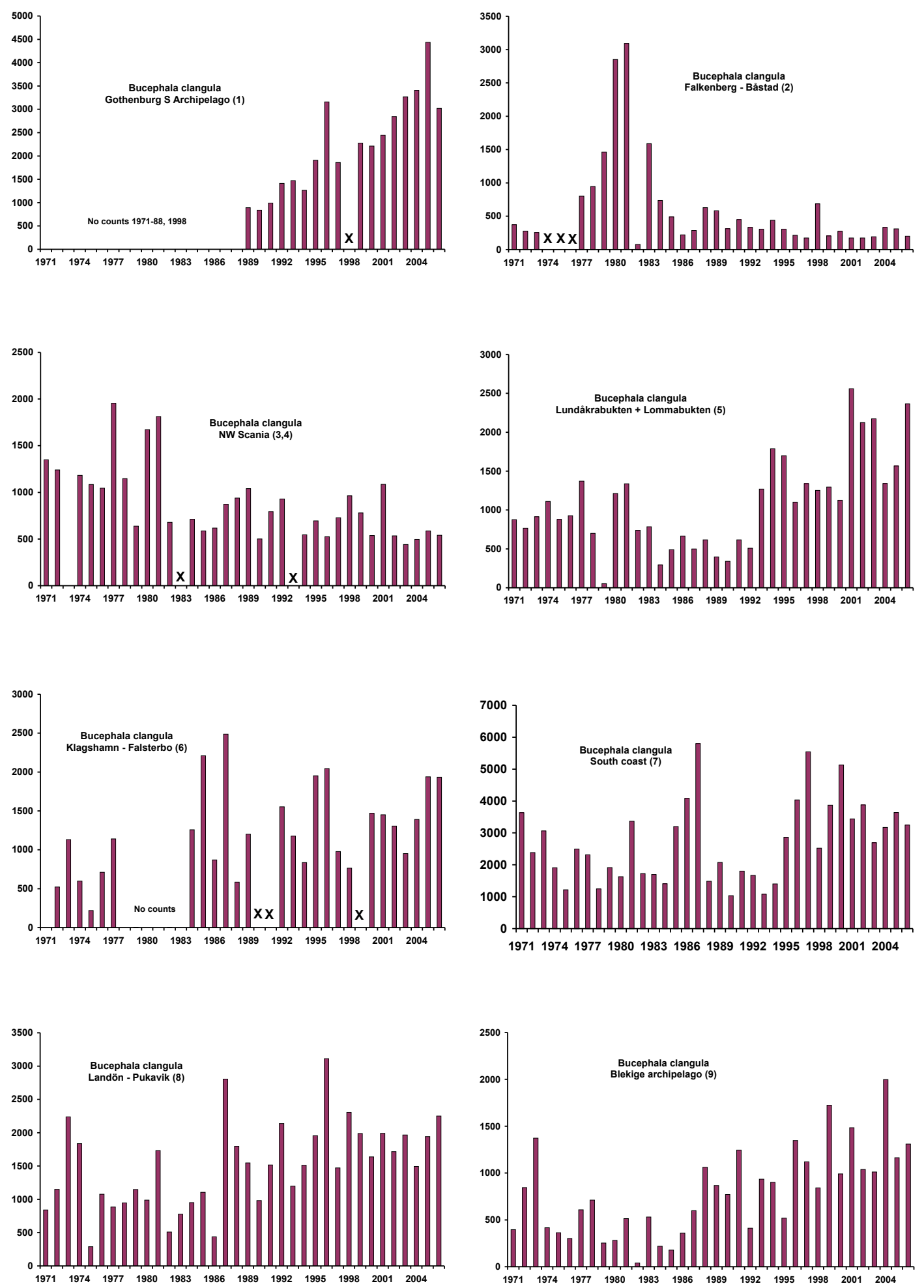


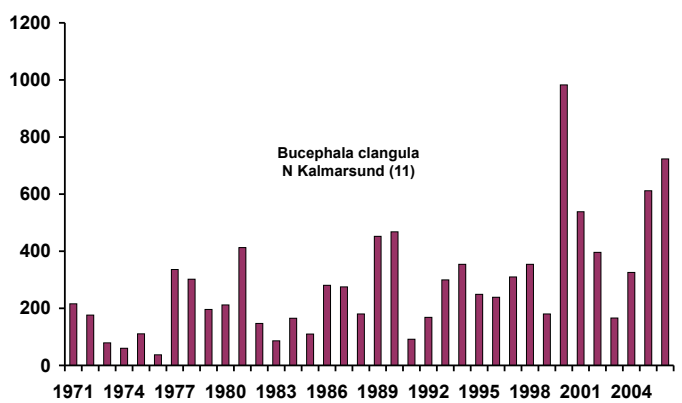

197119741977198019831986198919921995199820012004

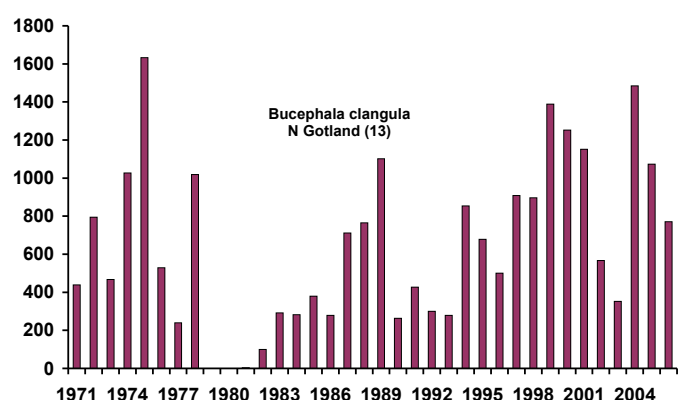

197119741977198019831986198919921995199820012004

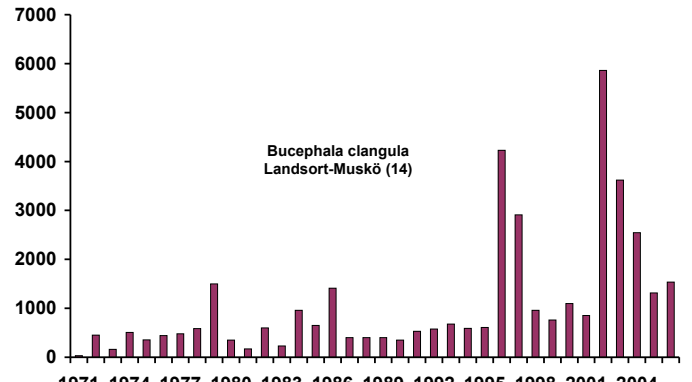

197119741977198019831986198919921995199820012004
Figure 20. Counts of Goldeneye Bucephala clangula in coastal reference areas (Figure 3) in Sweden in January 19712006. $X=$ No counts in the area this year.

Räkningar av knipa Bucephala clangula inom olika referensområden vid kusterna (Figure 3) i Sverige januari 19712006. $X=$ räkningar saknas detta år.

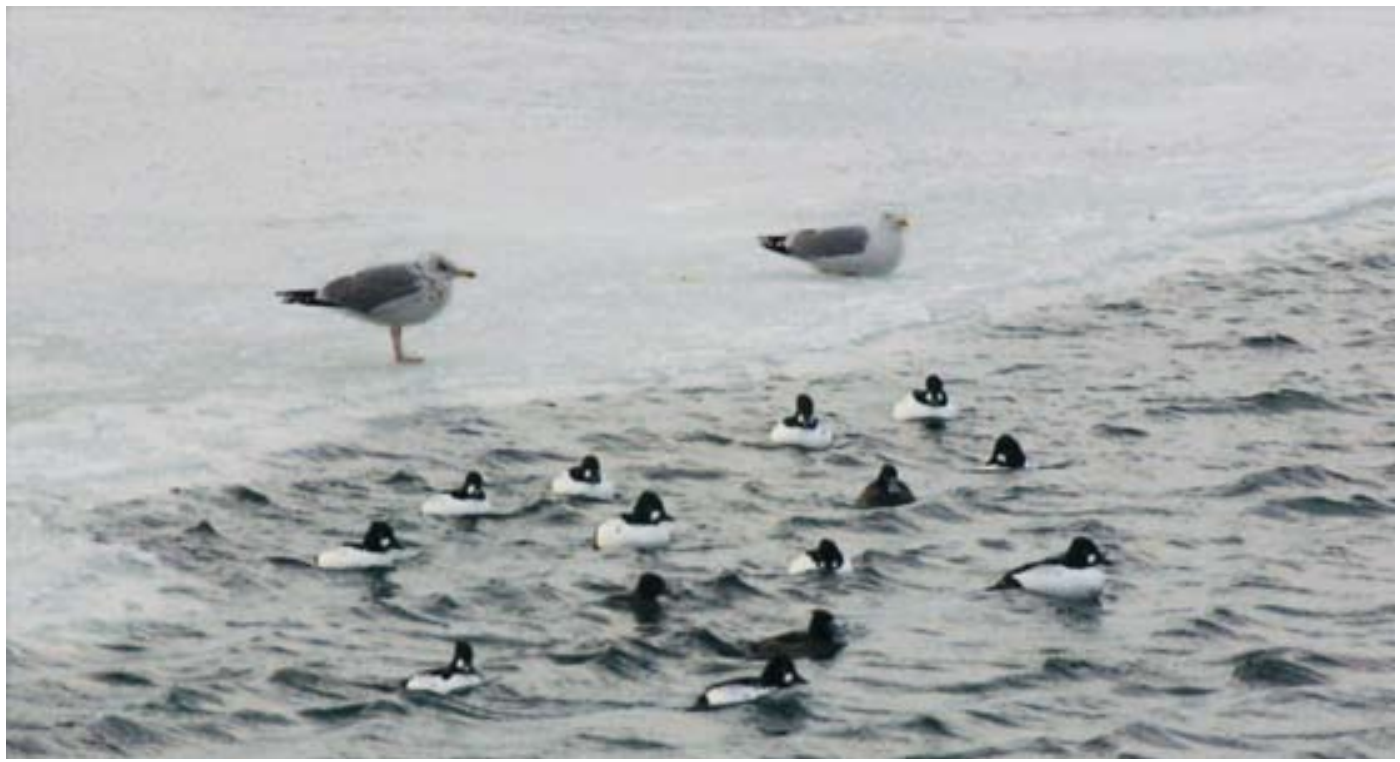




\section{Long-tailed Duck Clangula hyemalis}

The Long-tailed Duck is the most common duck wintering in Swedish waters. Including the offshore sea shallows the population wintering in Swedish waters in 1992-1993 was estimated to widely exceed one million individuals (Durinck et al. 1994). The Long-tailed Duck is not well covered in the annual Midwinter Counts as it requires special surveys of offshore waters, especially the banks in the mid-Baltic. A first attempt was made in 1992-1993 with boat surveys (Durinck et al. 1994) and a second survey started in 2007 (aerial surveys, Nilsson in prep.). Even if the Long-tailed Duck is mainly an offshore species appreciable numbers $(11,000$ $76,000)$ have been counted in the inshore coastal waters at the regular Midwinter Counts, but even the highest of these counts is only a small fraction of the totals present in Swedish waters during winter (cf. Durinck et al 1994, Nilsson unpubl.).

The Long-tailed Duck occurs along the entire
Baltic coast of Sweden from Falsterbo north to Gävlebukten (north of the area included in the present study) (Figure 21). Long-tailed ducks are also seen on the west coast but in very small numbers. The map for 2004 is not fully representative for the Baltic archipelagos as the outermost zone with sea shallows was not covered in 2004, whereas it was counted in the 1970s.

There are not sufficient data for the calculation of national indices for the Long-tailed Duck, but three coastal reference areas have such depth profiles that the birds can be reliably counted from the shore (Figure 22). For two areas, the south coast of Scania (7) and Blekinge $(8,9)$, the counts were markedly higher during the 1970 s compared to later years. In the northern part of the distribution area counts from the shores at Väddö (15) during the 1990s were markedly higher than during the 1970s but counts during the last four years were again much lower.
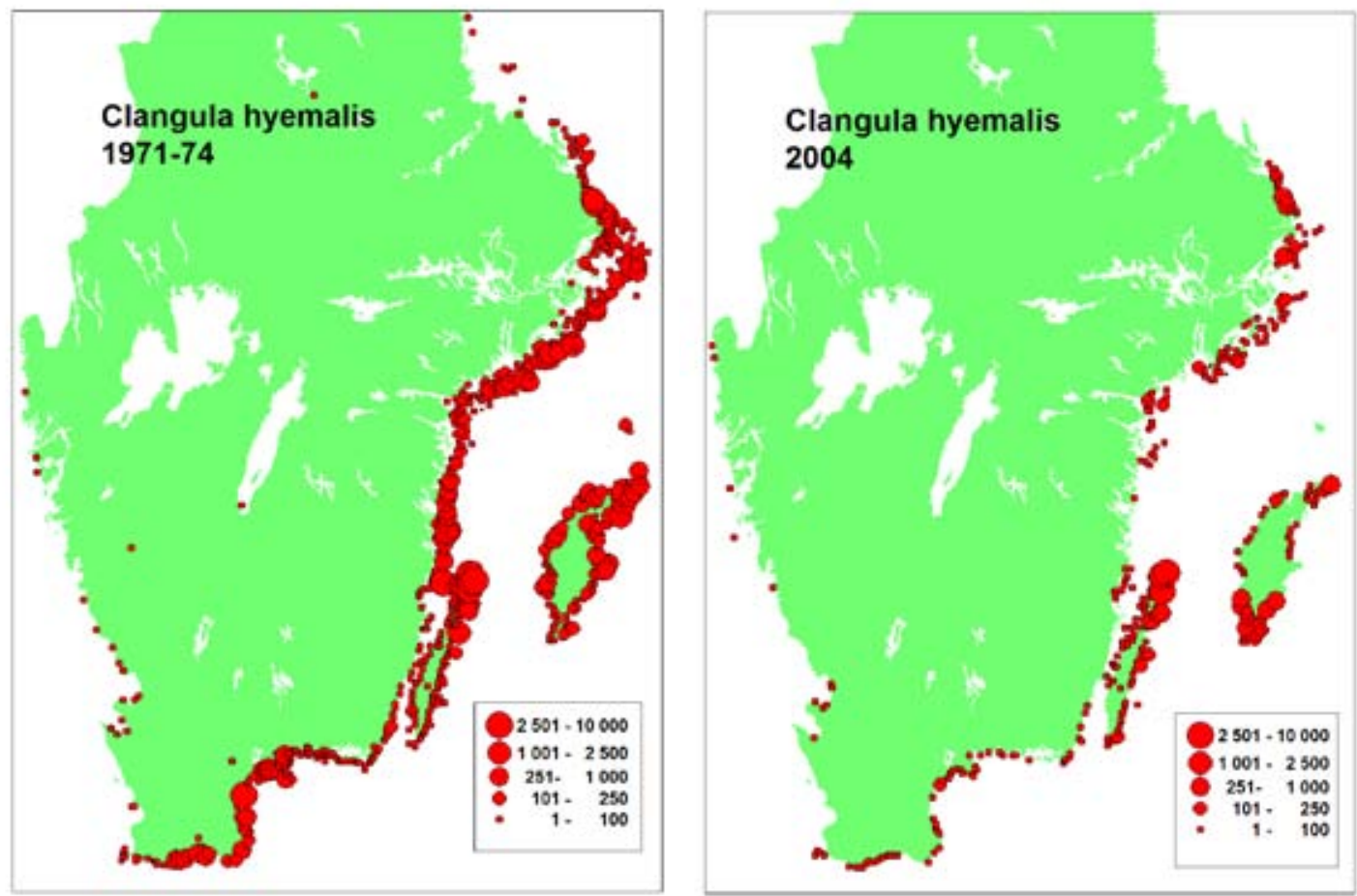

Figure 21. Midwinter distribution of Long-tailed Duck Clangula hyemalis in Sweden based on the country-wide surveys in 1971-1974 and 2004. Note that the outer parts of the archipelagos north of Kalmarsund were not adequately covered in 2004. Offshore areas are not included in the counts.

Midvinterutbredning för alfågel Clangula hyemalis $i$ Sverige baserad på de landsomfattande inventeringarna 1971-1974 och 2004. Observera att de yttre delarna av skärgårdarna norr om Kalmarsund ej täckts adekvat i januari 2004. Yttre havsområden omfattas inte av inventeringarna. 

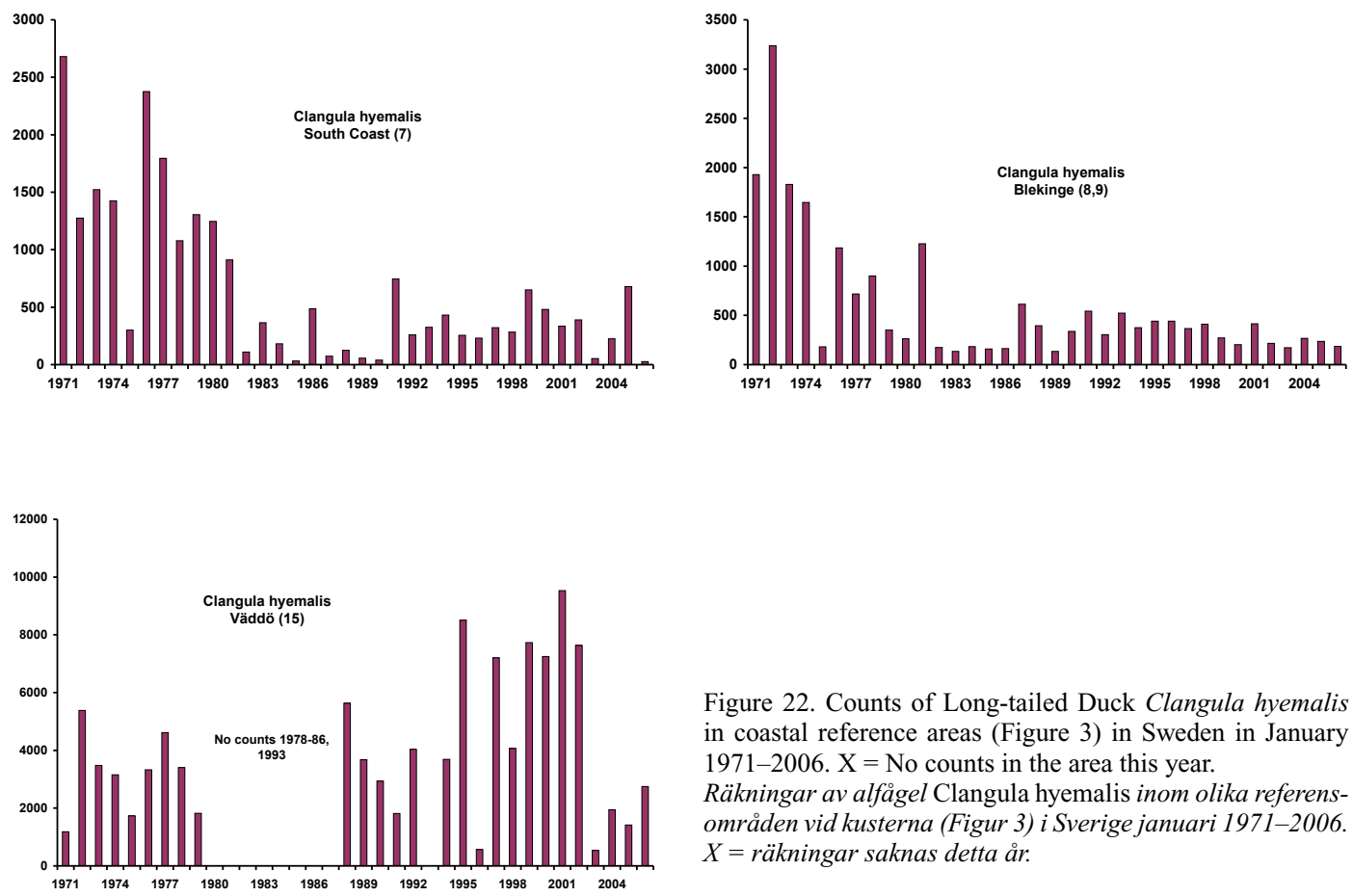

Figure 22. Counts of Long-tailed Duck Clangula hyemalis in coastal reference areas (Figure 3) in Sweden in January 1971-2006. $X=$ No counts in the area this year.

Räkningar av alfågel Clangula hyemalis inom olika referensområden vid kusterna (Figur 3) i Sverige januari 1971-2006. $X=$ räkningar saknas detta år.

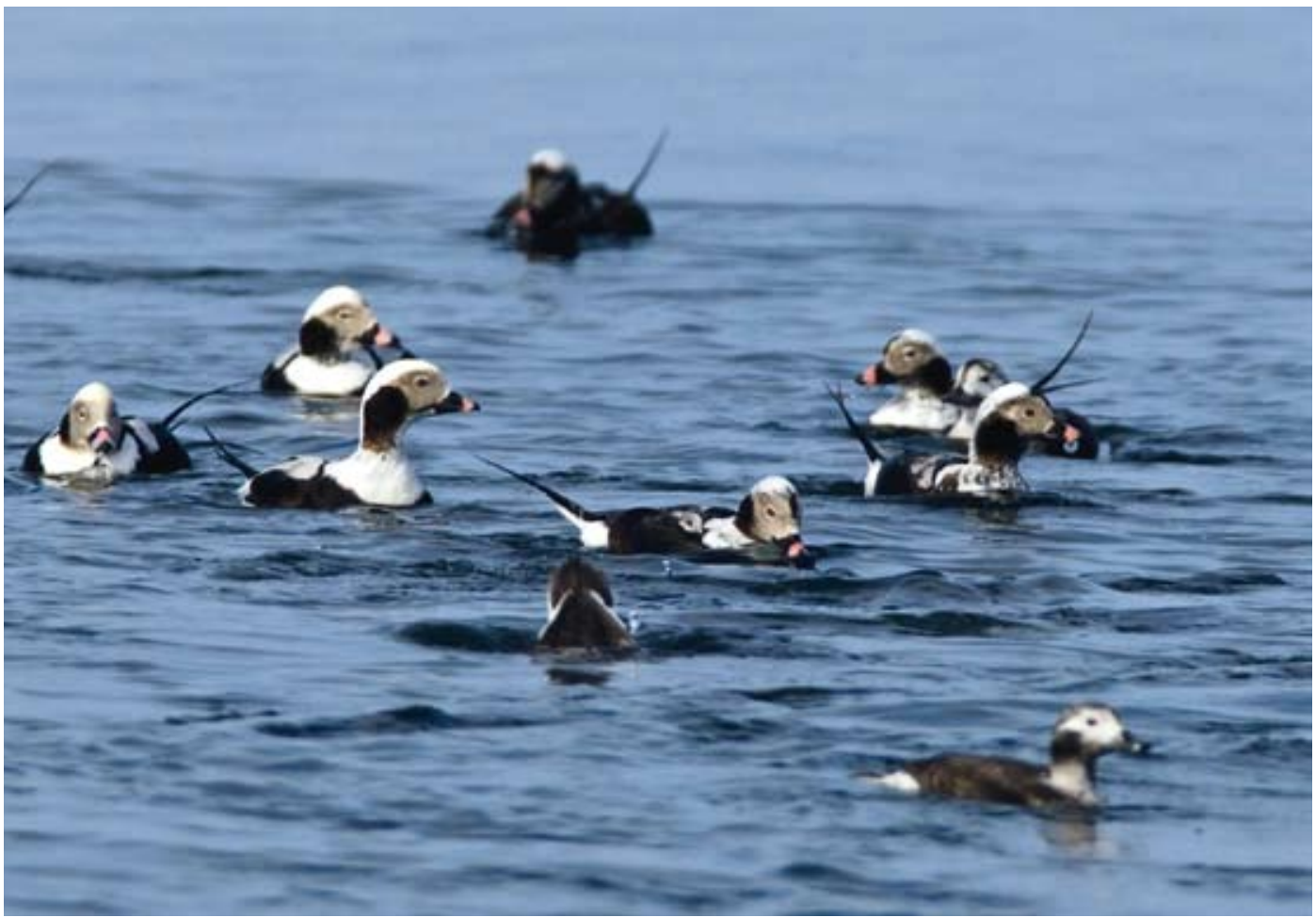




\section{Velvet Scoter Melanitta fusca}

The Velvet Scoter is another seaduck that is not adequately covered by the annual Midwinter Counts, offshore aerial surveys are needed. It was not so wide-spread as the Long-tailed Duck and both during offshore and inshore counts it was mainly found in Laholmsbukten and Skälderviken in the Kattegat area (reference areas 2, 3) but also in smaller numbers around Öland and Gotland and in Hanöbukten (Figure 23). Smaller numbers were also seen in different areas in the archipelagos on the east coast.
There are no reliable estimates of the total population, but numbers are probably not very large. On the west coast, the only occurrences of importance was found in Laholmsbukten and Skälderviken, where the totals were around 1800-2000 in 19721973 and below 1000 during the surveys in 1988, 1989 and 2004. Preliminary results from offshore aerial surveys in the Baltic indicate a few thousand wintering Velvet Scoters in the waters of Hanöbukten and around Öland (Green \& Nilsson in prep.), but there can be concentrations in waters that are still not yet covered.
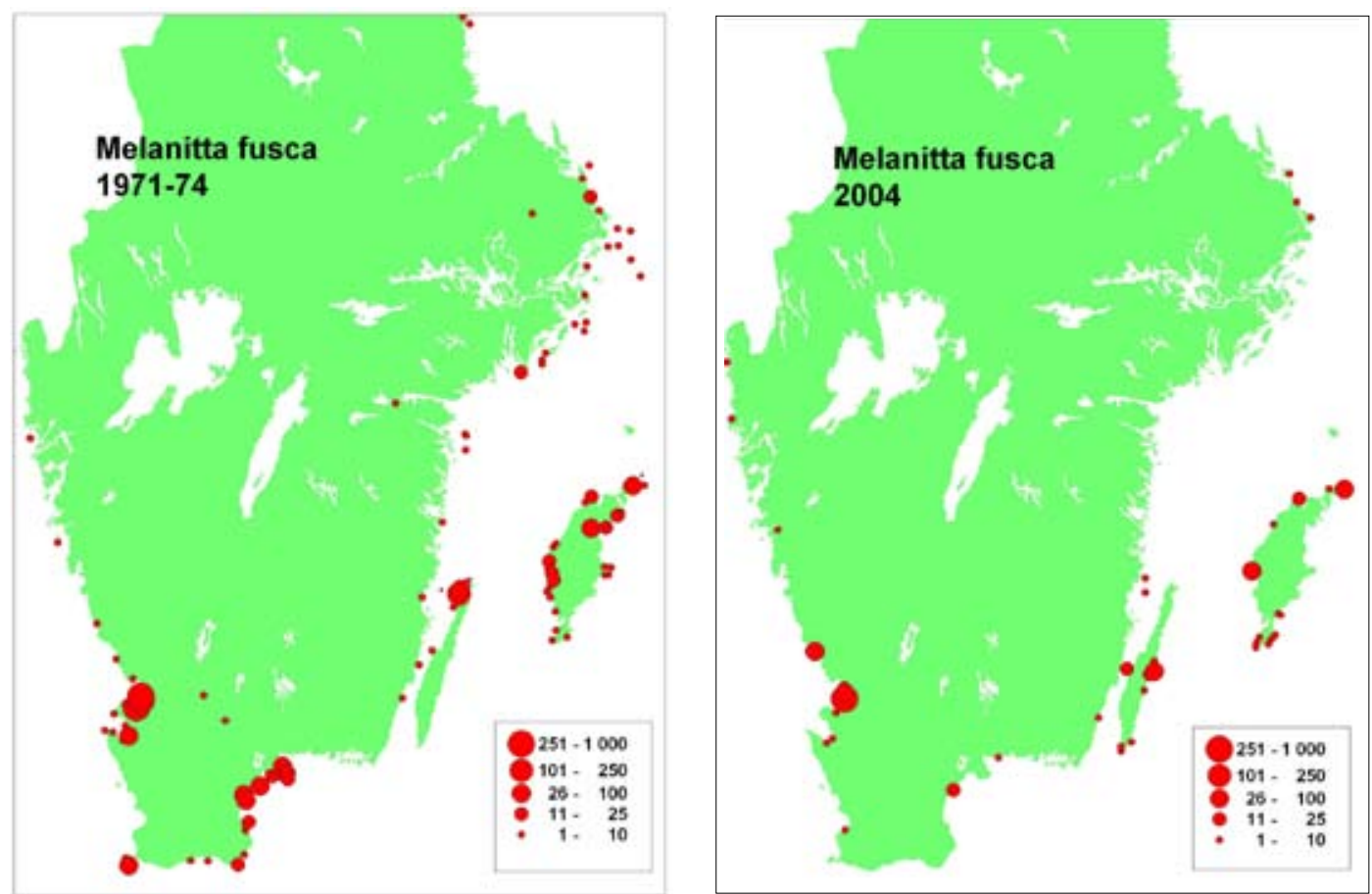

Figure 23. Midwinter distribution of Velvet Scoter Melanitta fusca in Sweden based on the country-wide surveys in 19711974 and 2004. Note that the outer parts of the Stockholm archipelago (O) were not adequately covered in 2004. Offshore areas are not included in the counts.

Midvinterutbredning för svärta Melanitta fusca $i$ Sverige baserad på de landsomfattande inventeringarna 1971-1974 och 2004. Observera att de yttre delarna av Stockholms skärgård (O i Figur 3) ej täckts adekvat i januari 2004. Yttre havsområden omfattas inte av inventeringarna. 


\section{Common Scoter Melanitta nigra}

The Common Scoter has a similar distribution as the Velvet Scoter and belongs to those seaducks that cannot be adequately covered in the annual Midwinter Counts from the shore line. The two species had more or less similar distribution (Figure 24). On the west coast the main area was Laholmsbukten and Skälderviken, but only a few hundred were counted here during the 1970s and 2500 in 2004.

In the Baltic Common Scoters were found in small numbers around the islands of Öland and Gotland and in Hanöbukten on the east coast of Scania during the regular counts in inshore waters. Preliminary results from the offshore aerial surveys in the Baltic indicate that up to 40,000 Common Scoters winters in the waters of Hanöbukten and the Kalmarsund+Öland area (Green \& Nilsson in prep.), an occurrence that is new comparing with the aerial and boat surveys in these areas during the 1970 s.
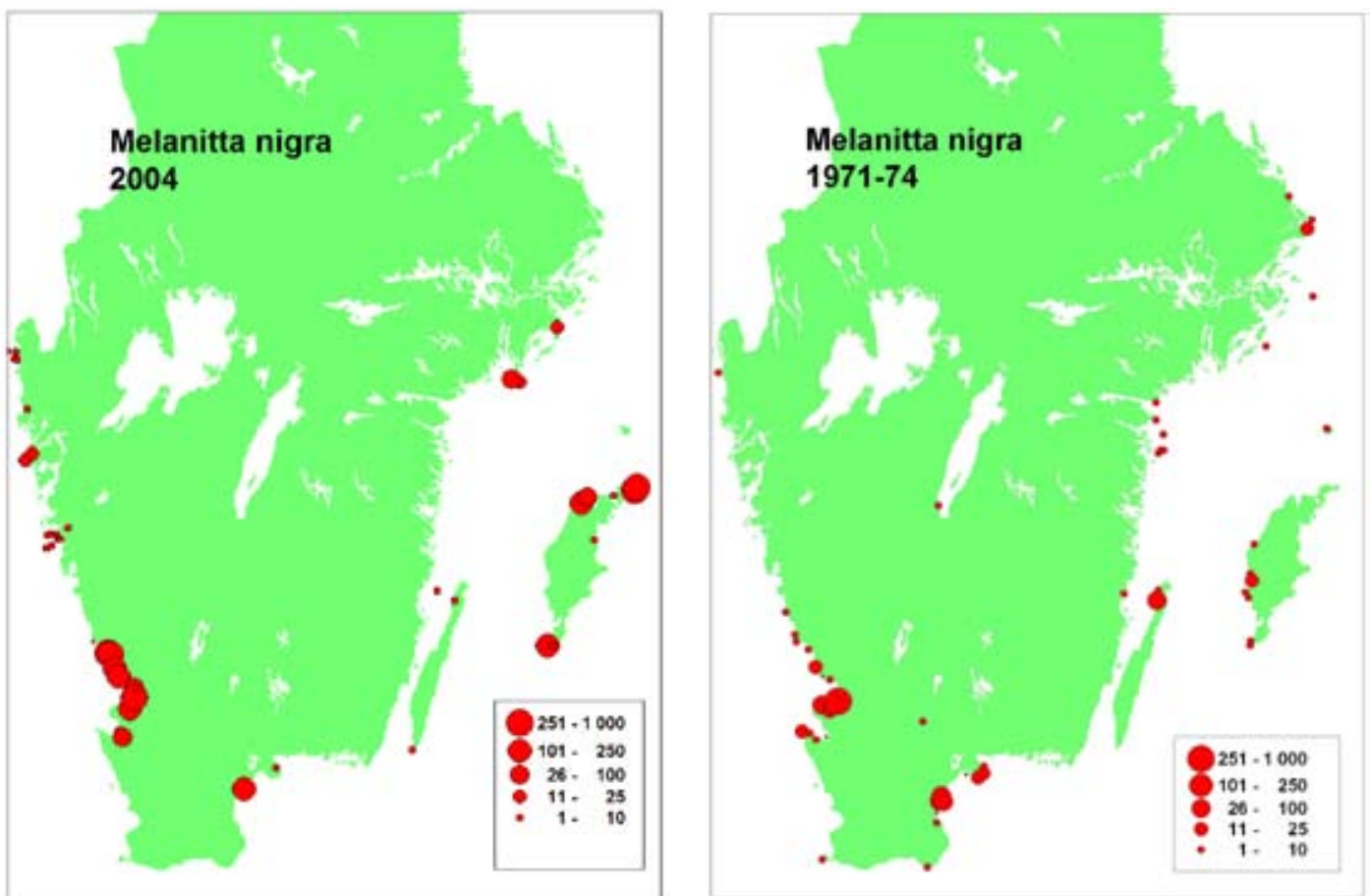

Figure 24. Midwinter distribution of Common Scoter Melanitta nigra in Sweden based on the country-wide surveys in 19711974 and 2004. Note that the outer parts of the Stockholm archipelago (O) were not adequately covered in 2004. Offshore areas are not included in the counts.

Midvinterutbredning för sjöorre Melanitta nigra Sverige baserad på de landsomfattande inventeringarna 1971-1974 och 2004. Observera att de yttre delarna av Stockholms skärgård (O i Figur 3) ej täckts adekvat i januari 2004. Yttre havsområden omfattas inte av inventeringarna. 


\section{Eider Somateria mollissima}

The national indices for the Eider showed marked variation between years, but the overall trend was significantly increasing when calculated over the entire survey period (Figure 25). Actually there were a number of years with low counts in 19671972 followed by an increase to a peak and then again low numbers for a number of years, until a marked increase, although with fluctuations between years, started in January 1988, i. e. after the last really cold winter in the series.

The Eider is a typical west coast species, and was widely spread along the entire west coast of the country from the Öresund to the Norwegian border (Figure 25). Eiders were also regular along the open coasts of the Baltic, including Scania, Öland and Gotland, but in much smaller numbers here even if they were well spread.

The country-wide surveys found a population of about 50,000 wintering Eiders in January 2004 compared to 4600 in January 1971. In the Baltic archipelagos just a few hundred Eiders were seen in any of the larger surveys (Table 5, appendix). The national increase in Eider numbers in January was due to changes on the west coast. In contrast to the other seaducks the distribution of the Eiders was well covered at the country-wide surveys presented here.

The reference areas on the west coast showed the same pattern as the national indices (Figure 26), whereas there was a decrease in wintering Eiders along the shore of Scania and Blekinge $(7,8,9)$. In Kalmarsund $(10,11)$ fluctuations were found, probably related to different strength of the winter.

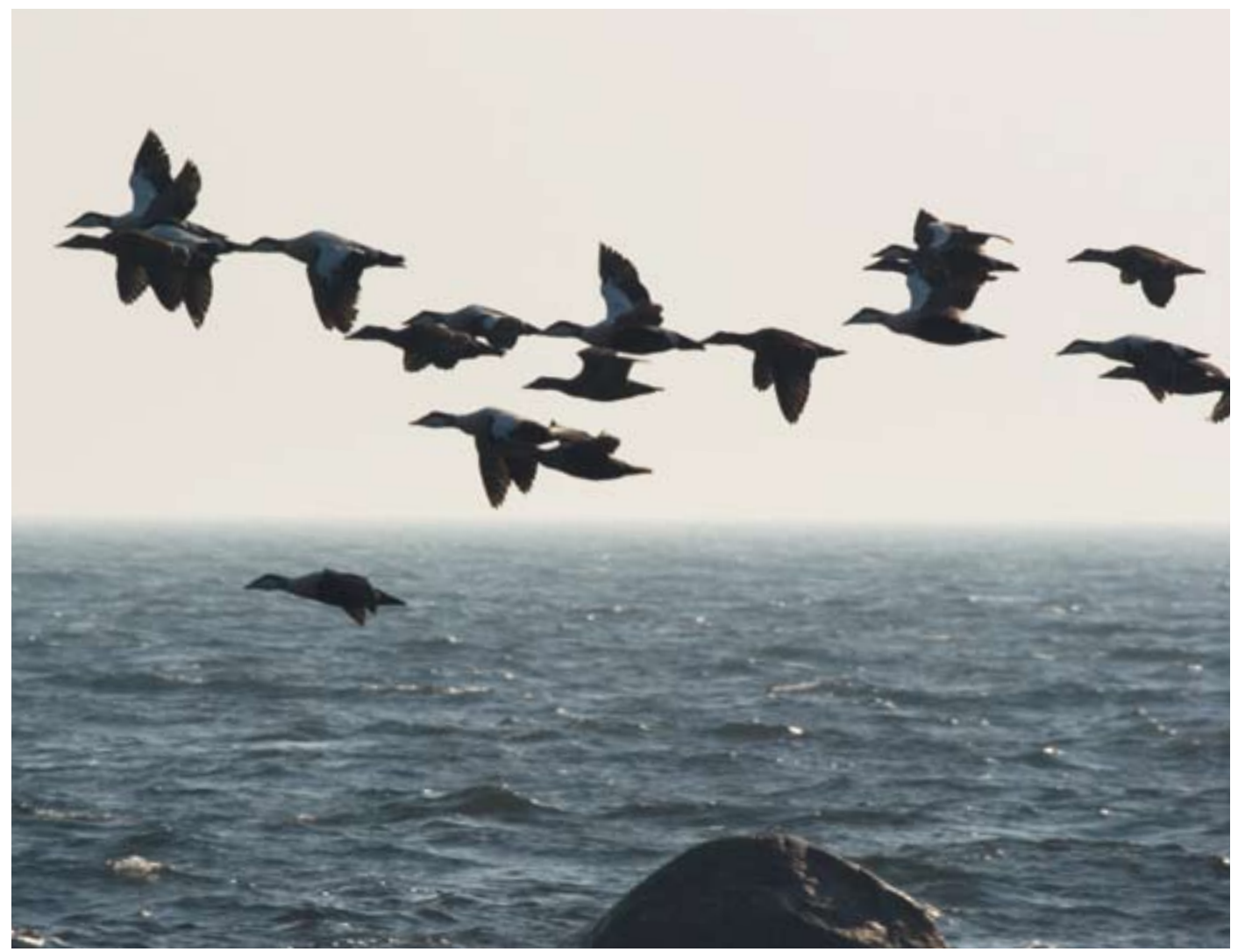



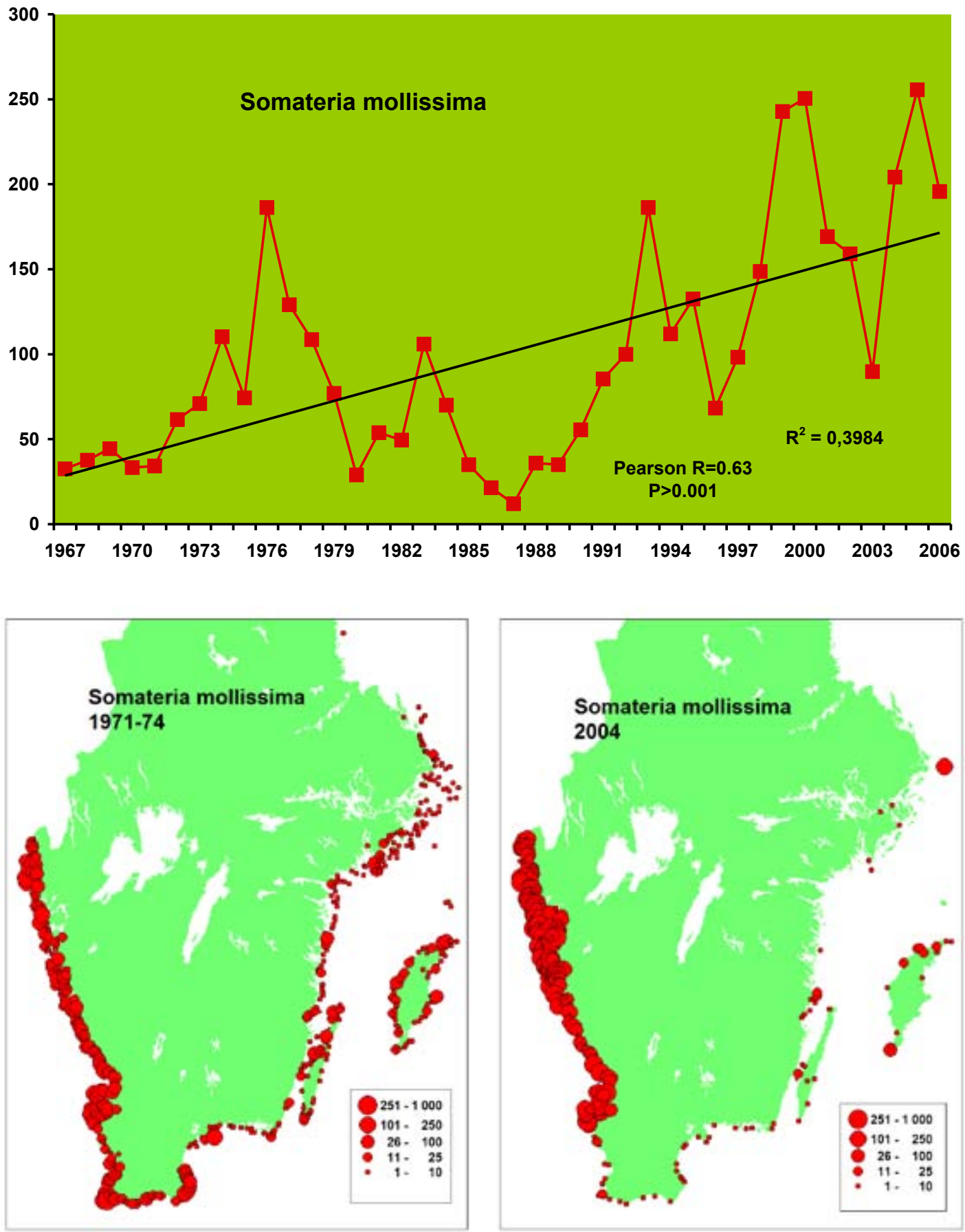

Figure 25. Eider Somateria mollissima. Midwinter population indicdes and distribution maps.

Ejder Somateria mollissima. Populationsindex och utbredningskartor för midvintern. 

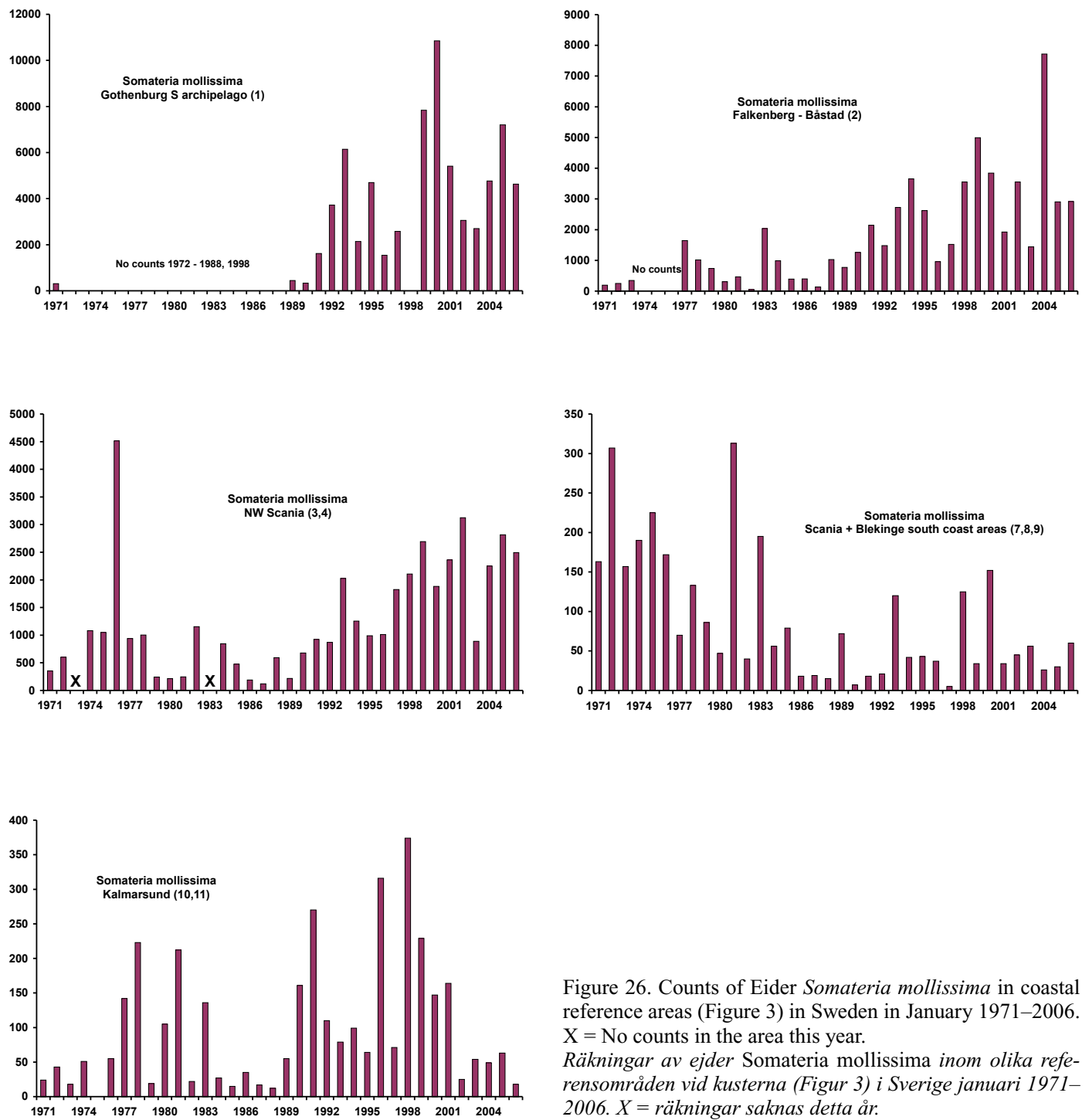

Figure 26. Counts of Eider Somateria mollissima in coastal reference areas (Figure 3) in Sweden in January 1971-2006. $\mathrm{X}=$ No counts in the area this year.

Räkningar av ejder Somateria mollissima inom olika referensområden vid kusterna (Figur 3) i Sverige januari 19712006. $X=$ räkningar saknas detta år. 


\section{Red-breasted Merganser Mergus serrator}

The national indices showed a steadily increasing trend since the start of the midwinter counts (Figure 27), the trend being similar to that of the Goldeneye. Between 1967 and 1982 fluctuations around the trend-line were small, but in the later years quite marked fluctuations between years were found.

The Red-breasted Merganser can also be classified as a seaduck as its distribution was mainly confined to the coasts of Sweden with only very few observations from inland sites (Figure 27). The species was distributed along the coasts from the west coast to and including Kalmarsund in the Baltic and around the islands of Öland and Gotland, whereas it was not very common in the east coast archipelagos further north. Part of the population was distributed well inshore and enough sites could be covered regularly for the production of good data for index calculations.

At the country wide survey in 2004 the total number of Red-breasted Merganser was estimated to be 6000 compared to 2500 in the same areas in 1971. The distribution was more ore less the same in the two surveys. The population estimates are probably underestimates as no less than 12,000 Red-breasted Mergansers were found in the waters off the southern part of Öresund and around Falsterbo (offshore to area 6) in the winter of 2006, large flocks being found here also in earlier winters (Green \& Nilsson 2006). Unpublished results from aerial surveys in other offshore areas of the Baltic did however not find any larger concentrations of the species, but a more realistic estimate of the population size at the present may be 15,000 20,000 individuals for the entire Swedish waters. There was no concentration of Red-breasted Mergansers in southern Öresund in the early seventies according to aerial surveys and boat counts in the area.

Counts in the reference areas showed increases for most areas except the Kalmarsund, where only marked fluctuations were found (Figure 28).

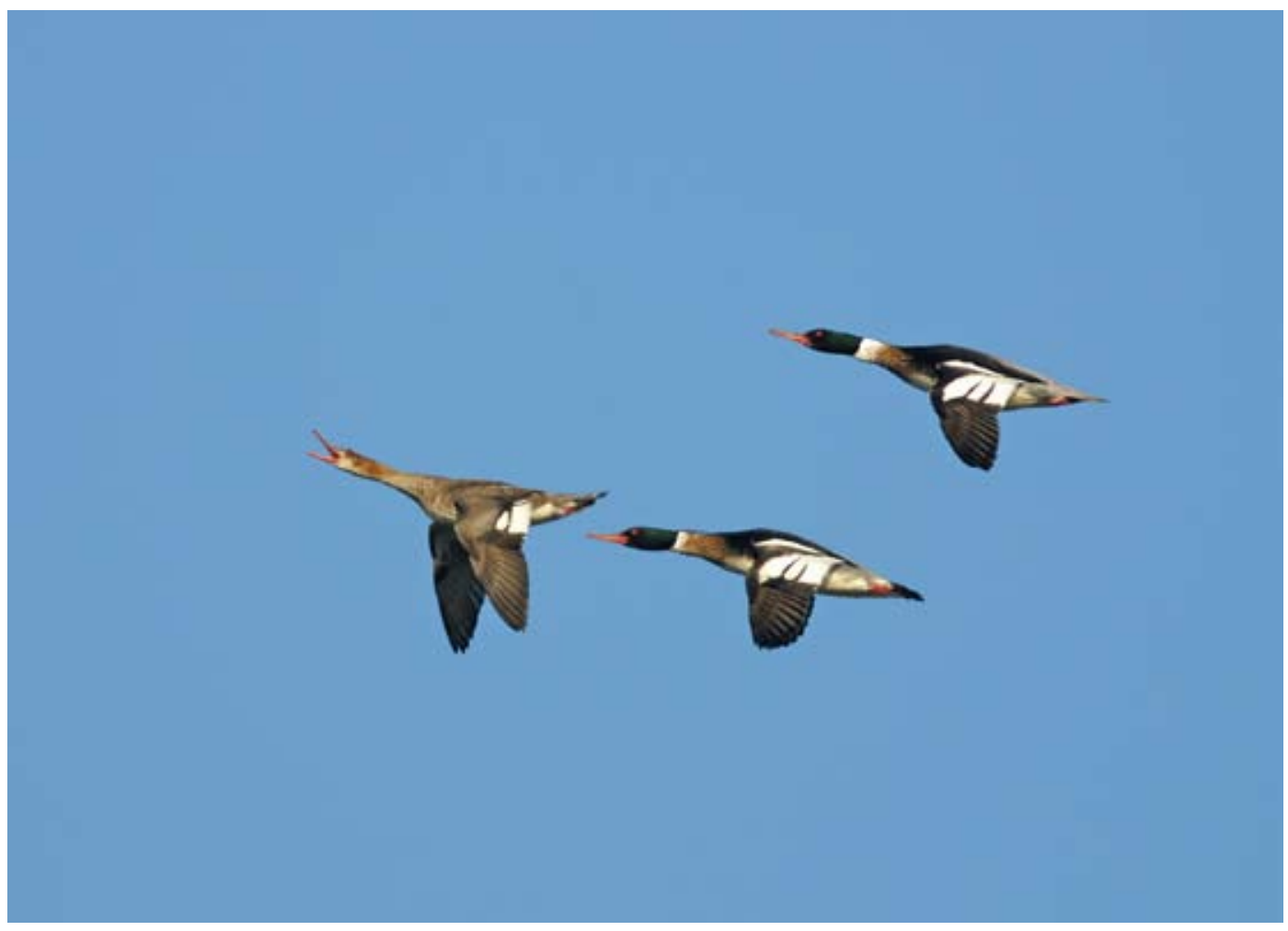



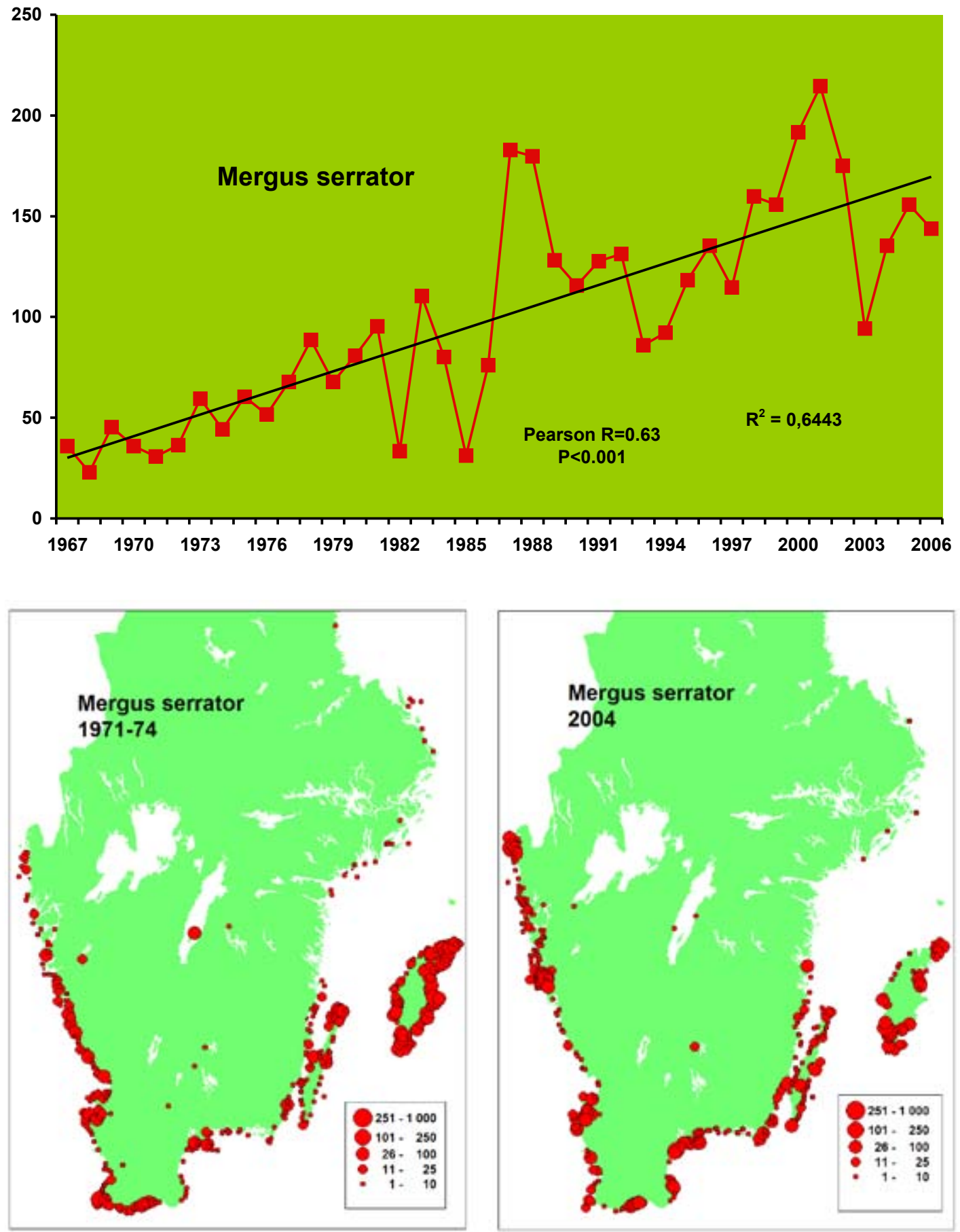

Figure 27. Red-breasted Merganser Mergus serrator. Midwinter population indices and distribution maps. Småskrake Mergus serrator. Populationsindex och utbredningskartor för midvintern. 

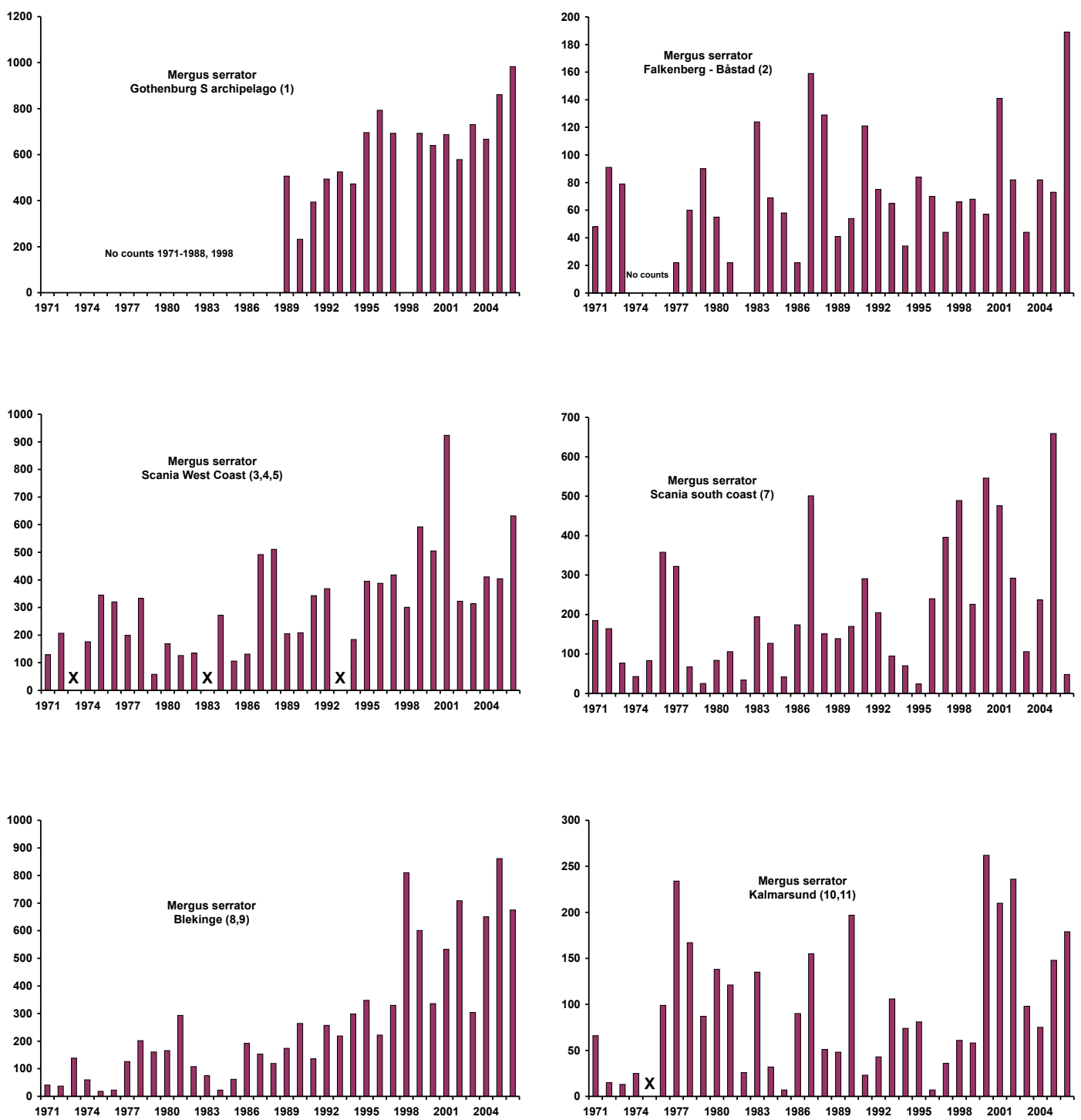

Figure 28. Counts of Red-breasted Merganser Mergus serrator in coastal reference areas (Figure 3) in Sweden in January 1971-2006. $X=$ No counts in the area this year.

Räkningar av småskrake Mergus serrator inom olika referensområden vid kusterna (Figur 3) i Sverige januari 1971-2006. X = räkningar saknas detta år. 


\section{Goosander Mergus merganser}

The Goosander is one of the few species for which the midwinter indices do not show any clear trend but only fluctuations (Figure 29). On the other hand the indices showed a marked increase from a low level in 1967 to a peak in 1979. They were then low during the 1980s with the cold winters but remained low until a peak in 1993. Then there was once more a decrease. It is however most probable that this decrease was only an effect of a dispersal of the Goosanders from the coastal sites well covered in the index calculations to a large number of inland sites which were not so well covered. Large fluctuations between different years were also seen in the reference areas (Figure 30). A majority of the Goosanders were counted in large flocks even if the species was also wide-spread on small inland waters in small groups and single individuals. The large flocks were quite moveable and this caused variations in the annual indices as flocks move in and out of the reference areas between years.

The Goosander was wide-spread in both inland and coastal waters in all parts of the country so long as there was open water (Figure 29). It was gener- ally more spread on the east coast than on the west coast. The Goosander was also to a large extent an inland species with large numbers remaining inland as long as there was open water available.

At the country-wide survey in 1971 the total wintering population was estimated to be 8600 compared to about 25,000 in January 2004 (Table 2). The estimate for 2004 is a minimum as the Goosander was well spread on small inland waters and these were not as well covered in 2004 as in the early seventies. Actually, 18,000 were counted in the coastal areas covered (appendix) in the counts. In addition to this about 2000 or more were probably present on coastal waters to the north of the area normally surveyed. A large proportion of open small inland waters were not surveyed and as 2000 birds were found on the sites covered it is highly probable that at least 5000 Goosanders were staying inland in the winter of 2004. The Goosander is the only species where the two country-wide surveys indicate a marked increase in the winter population not shown in the annual indices. Apparently the sites used in the index calculations do not cover the Goosander distribution adequately.

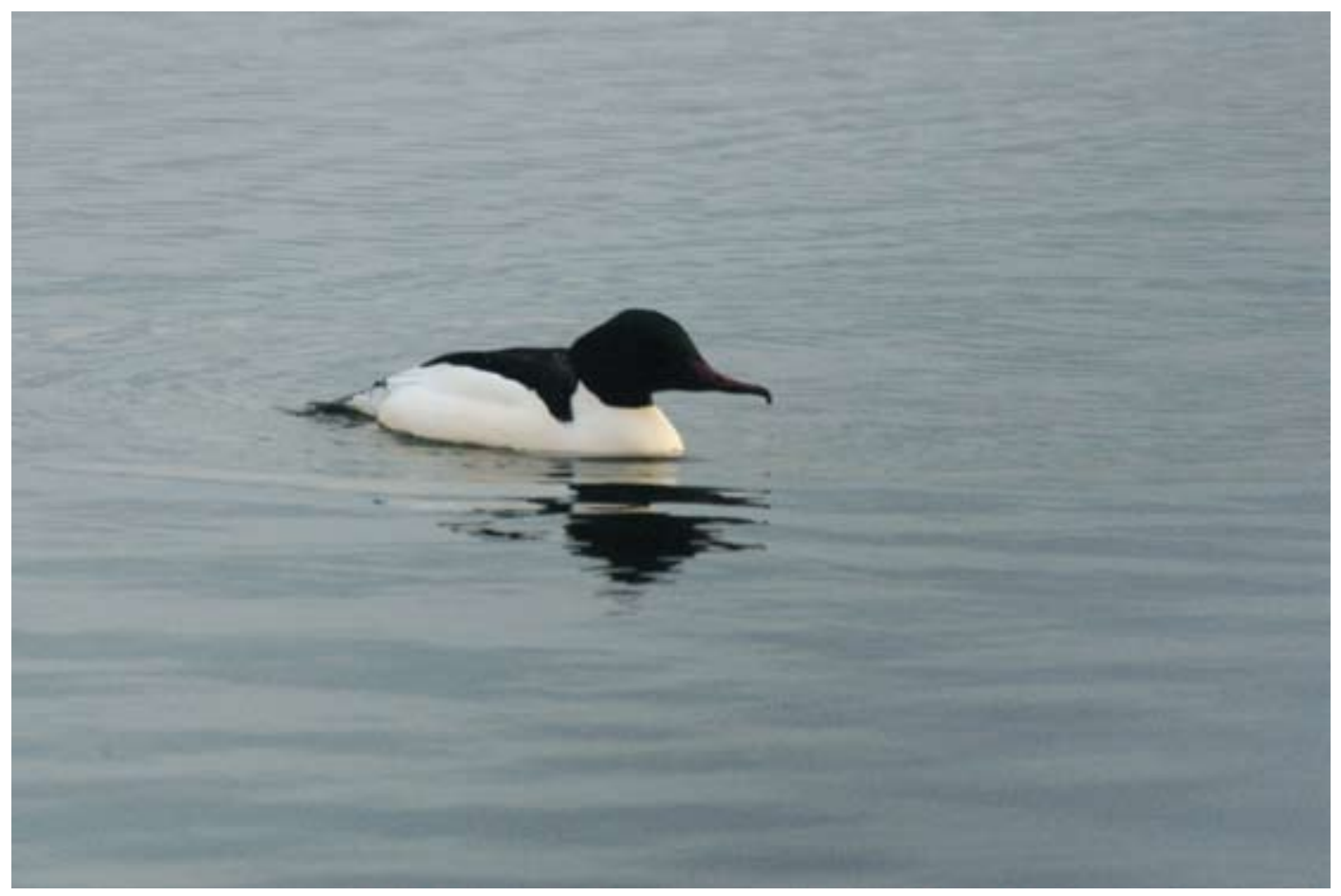



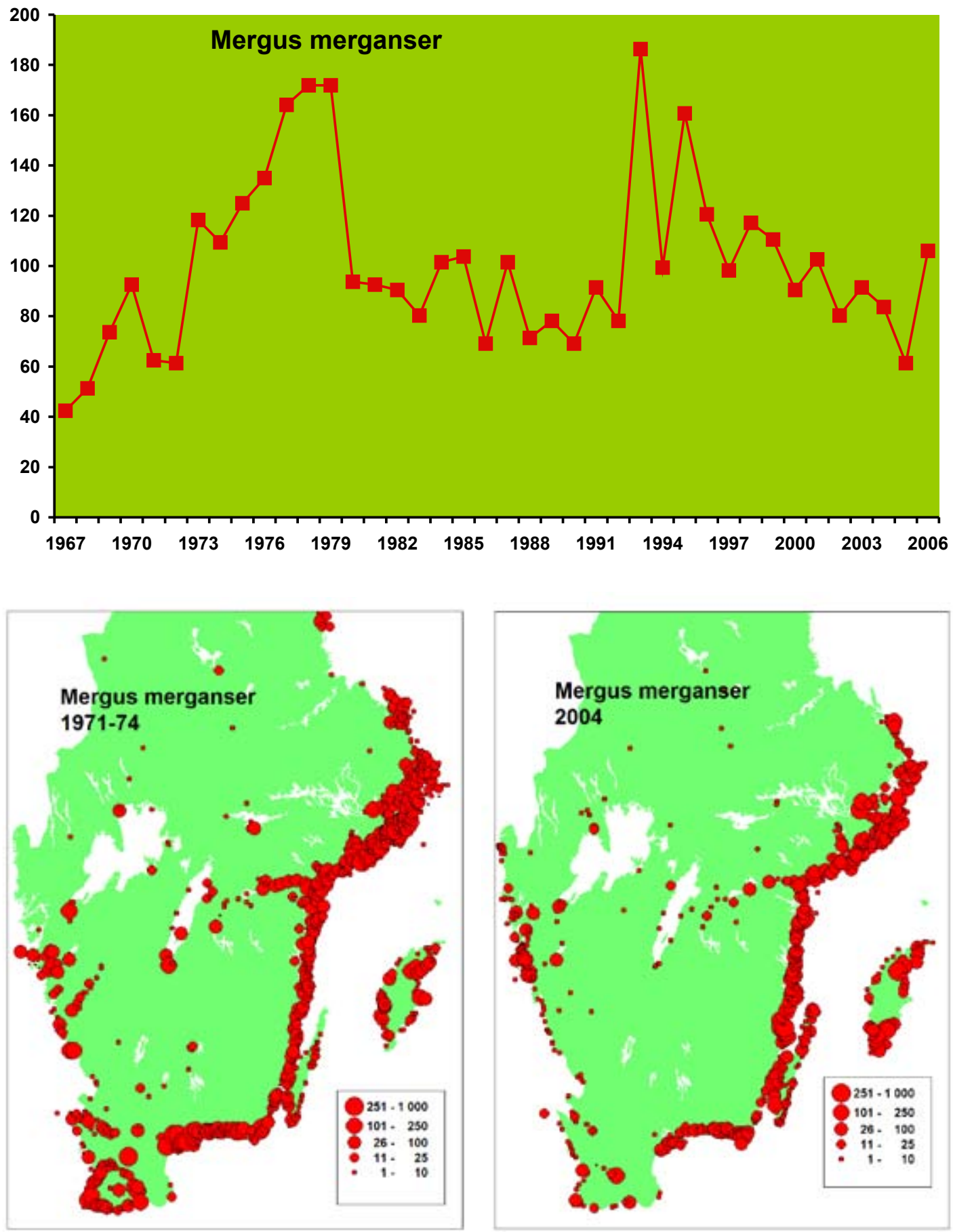

Figure 29. Goosander Mergus merganser. Midwinter population index and distribution maps. Storskrake Mergus merganser. Populationsindex och utbredningskartor för midvintern. 

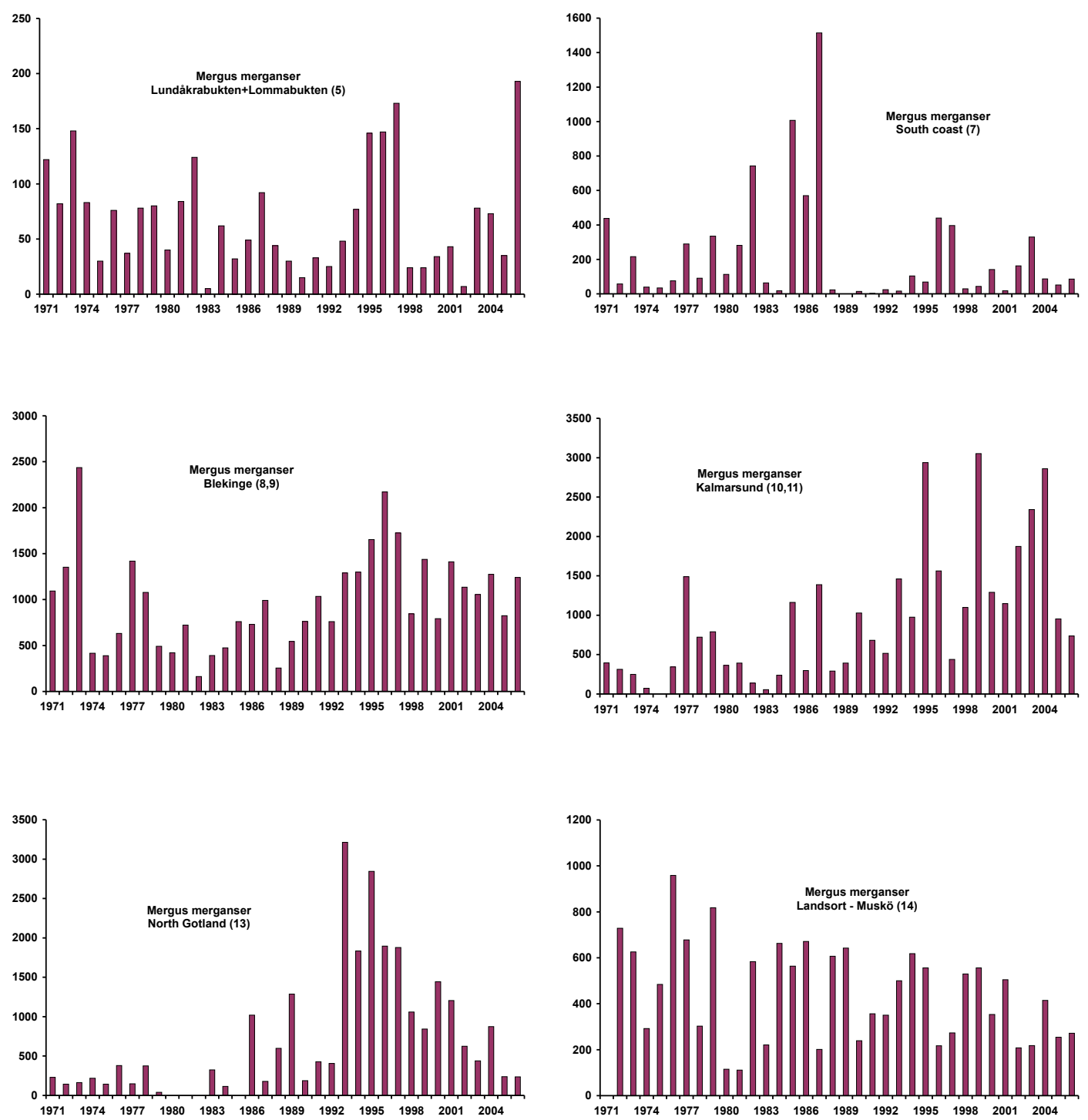

Figure 30 Counts of Goosander Mergus merganser in coastal reference areas (Figure 3) in Sweden in January 1971-2006. X $=$ No counts in the area this year.

Räkningar av storskrake Mergus merganser inom olika referensområden vid kusterna (Figur 3) i Sverige januari 1971-2006. $X=$ räkningar saknas detta år. 


\section{Smew Mergus albellus}

When the counts started, the Smew was a rather rare duck species in Sweden, with smaller flocks seen in the two southernmost provinces of Scania and Blekinge (Figure 31). In the other parts of south Sweden single individuals were regularly found. The situation was similar until about 1995 (Figure 32). Then there was an increase in the number of wintering Smews and also a spread of flocks along the Baltic coast. The total wintering population in January 2004 was estimated to be 3800 compared to 400 in January 1971. Blekinge was still the dominating province for the Smew, but quite large numbers were also found in Kalmarsund and on Gotland (Figure 31, appendix).

The number of Smews counted was too small to allow for the calculation of annual indices from the start. The totals for all reference areas remained in the level of about 300 for most years between 1987 and 1994 (Figure 32), but then a marked increase started and numbers on these areas together reached 3000 in 2006.

Among the reference areas, Öresund and especially Lommabukten + Lundåkrabukten (5), and Blekinge $(8,9)$ were the main areas for the Smew at the start of the counts, Blekinge being the most important one (Figure 33). Smews were also wintering in fair numbers on inland waters in Scania in mild winters, moving to the coast during colder periods. In later years only small numbers were counted in the Öresund. Smaller flocks were regular in Blekinge until 1995, when numbers increased markedly. In the two other main reference areas for the species, Kalmarsund $(10,11)$ and N. Gotland (13), it was irregular before 1995 when the increase started here too.
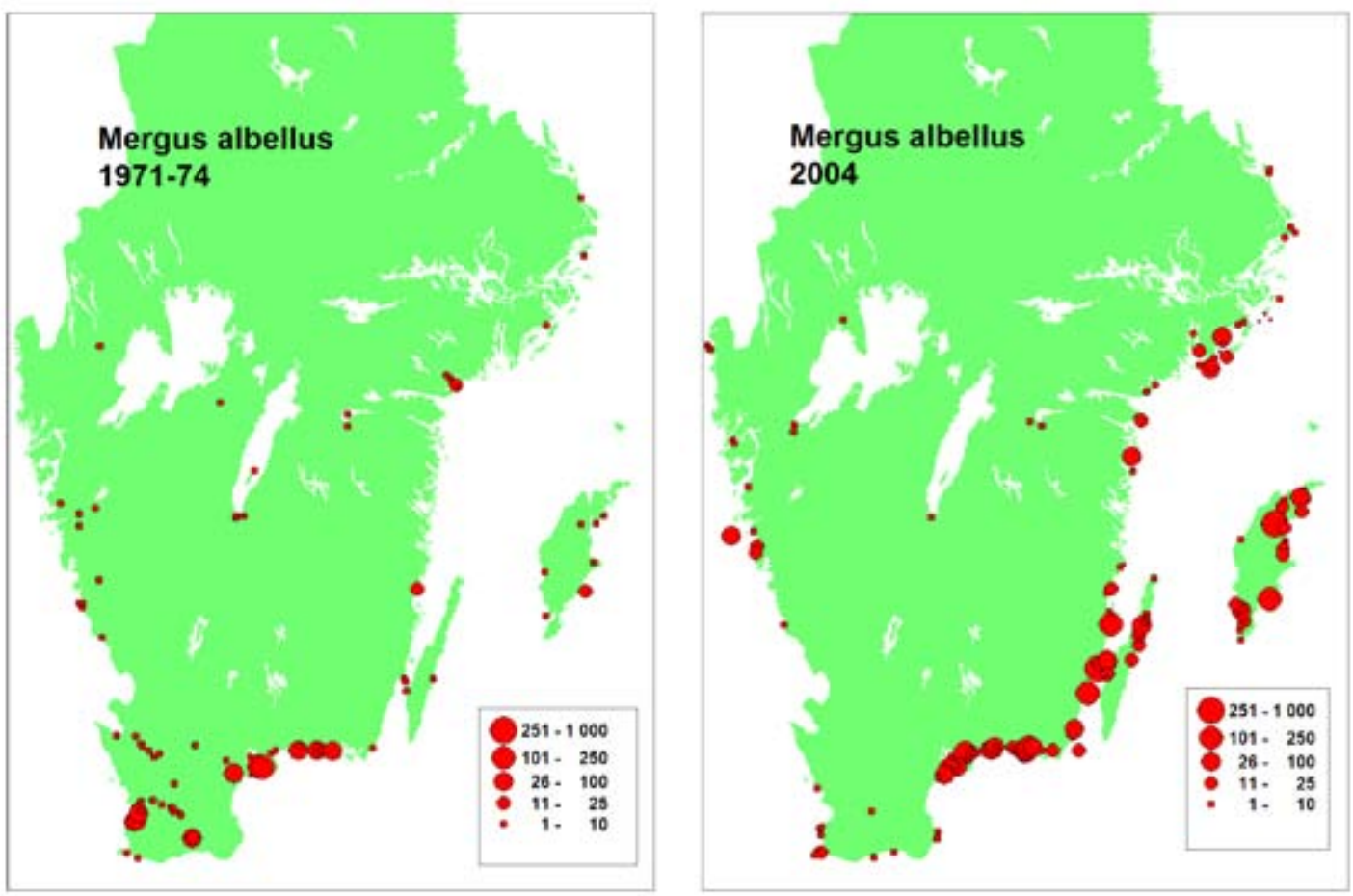

Figure 31. Smew Mergus albellus. Midwinter distribution maps.

Salskrake Mergus albellus. Utbredningskartor för midvintern. 


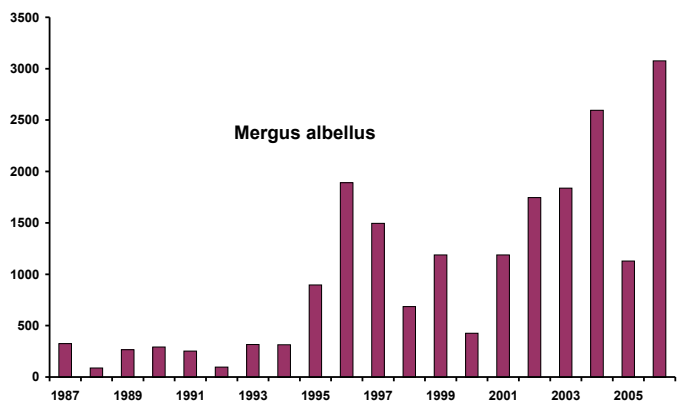

Figure 32.. Annual total counts of Smew Mergus albellus on all coastal reference areas (Figure 3) in Sweden in January 1987-2006.

Arliga totalsummor av salskrake Mergus albellus på samtliga referensområden vid kusterna av Sverige (Figur 3) januari 1987-2006.
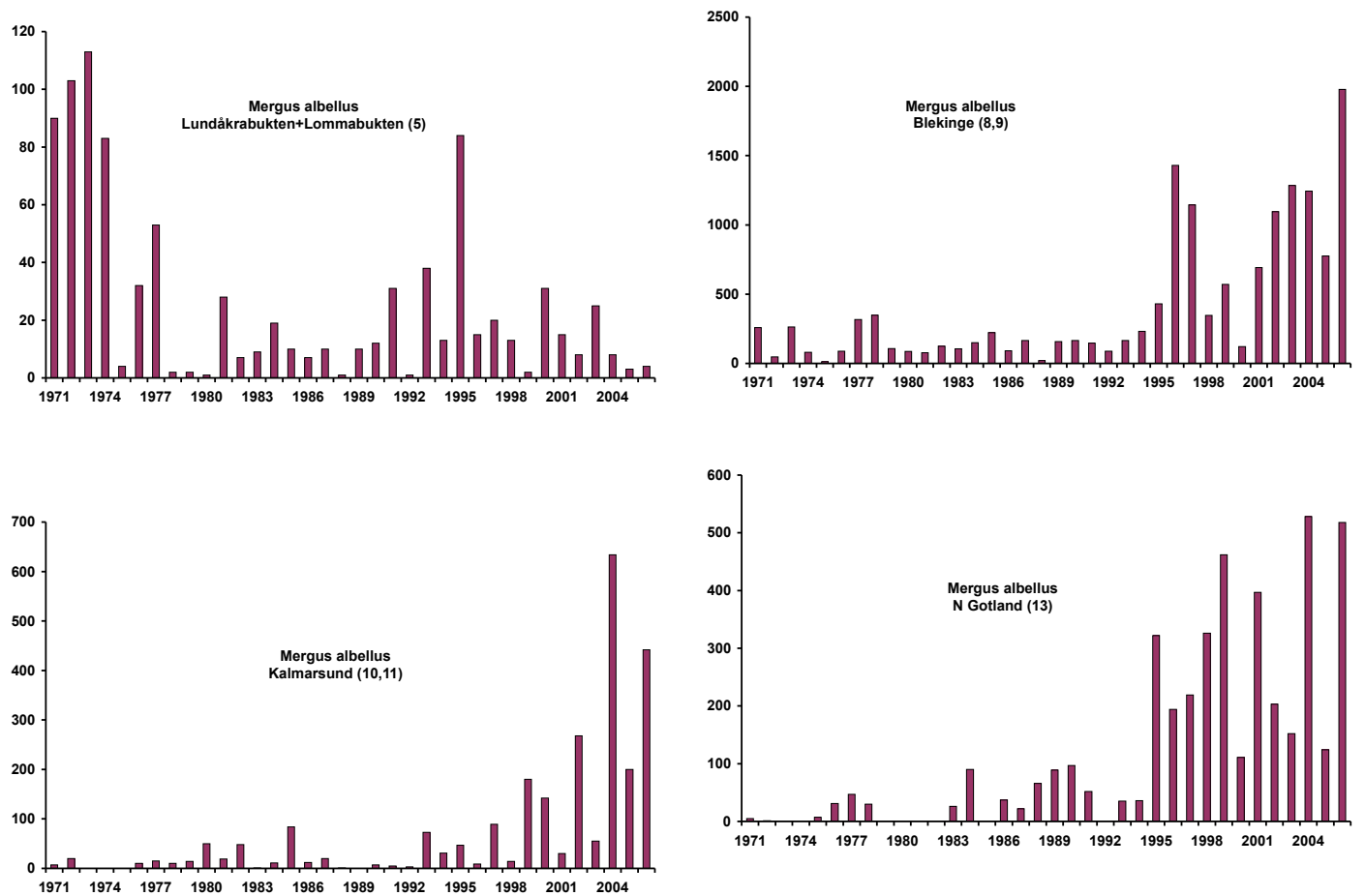

Figure 33. Counts of Smew Mergus albellus in coastal reference areas (Figure 3) in Sweden in January 1971-2006. X= No counts in the area this year.

Räkningar av salskrake Mergus albellus inom olika referensområden vid kusterna (Figur 3) i Sverige januari 1971-2006. X = räkningar saknas detta år. 


\section{Mute Swan Cygnus olor}

During the first years, 1967-1973, Mute Swan midwinter indices were very stable showing only slight fluctuations between years, but then a steady and significant increase started (Figure 34)

The Mute Swan was common and wide-spread (Figure 34) with flocks found along the entire coast included in the Midwinter Counts and also with smaller numbers found on a number of inland sites. At the country-wide survey in 1971 the total population of wintering Mute Swans was estimated to be 7500 compared to 35,000 in January 2004. Mute Swans were only seen in small numbers at the coasts of Gästrikland and Hälsingland in 2004, but the coverage of the inland sites was relatively low in this year when many inland water areas were open. With 2000 Mute Swans counted on in- land sites in 2005 (the year of the special Whooper Swan Survey, see below) it is reasonable that the total population wintering in the country was at least 35,000 in 2004.

The increase in numbers of wintering Mute Swans is common to all reference areas (Figure 35) but it was not so evident in the three areas in Scania, old strongholds for moulting flocks of Mute Swans and for wintering swans, as in the rest of Sweden. In the Öresund areas (3-5) increases were found but they were not very marked until later than in most other areas. In the southernmost area in the Öresund around Foteviken and Falsterbo (6), there was no clear increase in numbers with peak counts in mild winters of 3000-3500 Mute Swans and marked fluctuations in relation to the ice situation in the years in between.

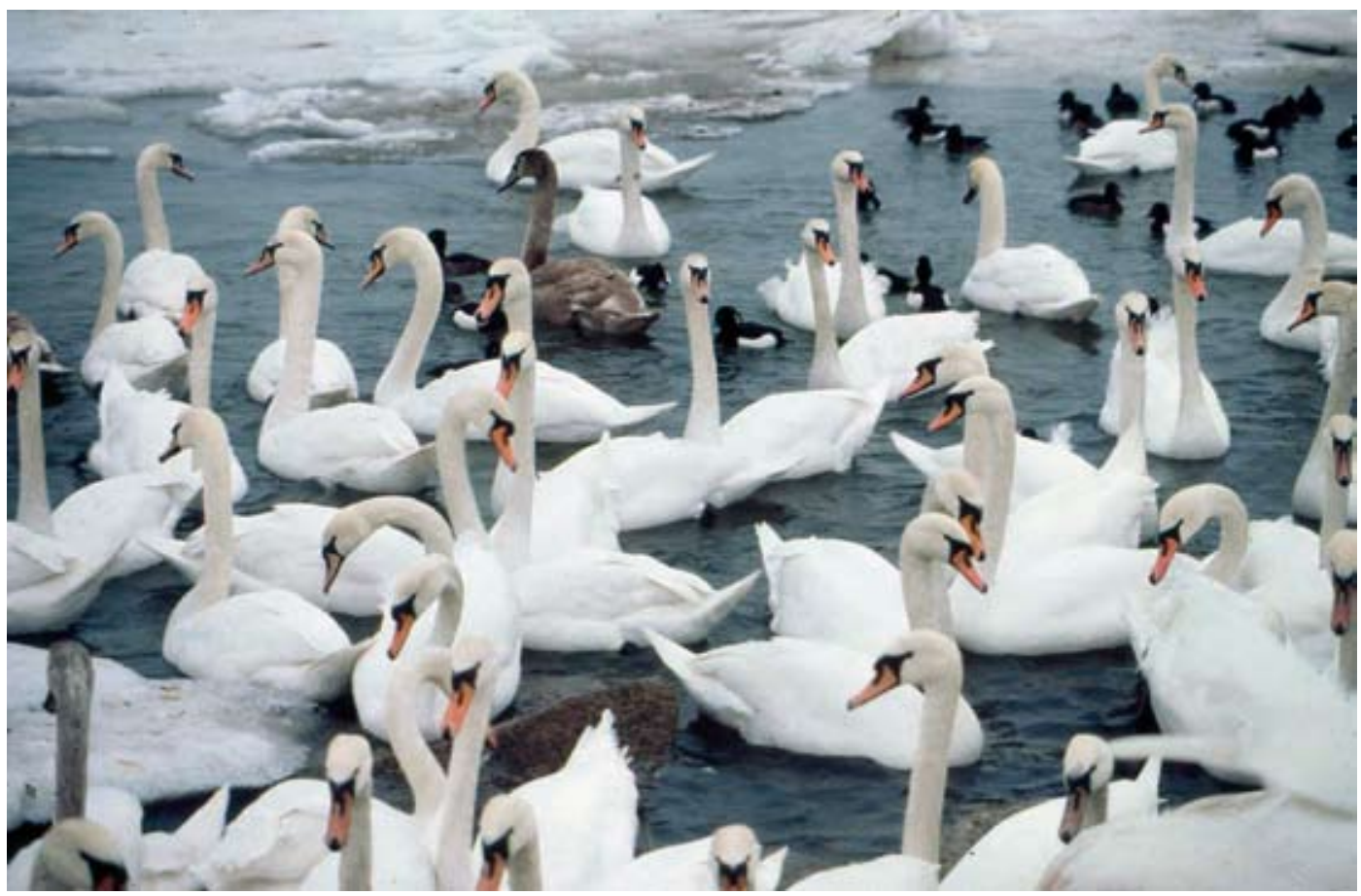



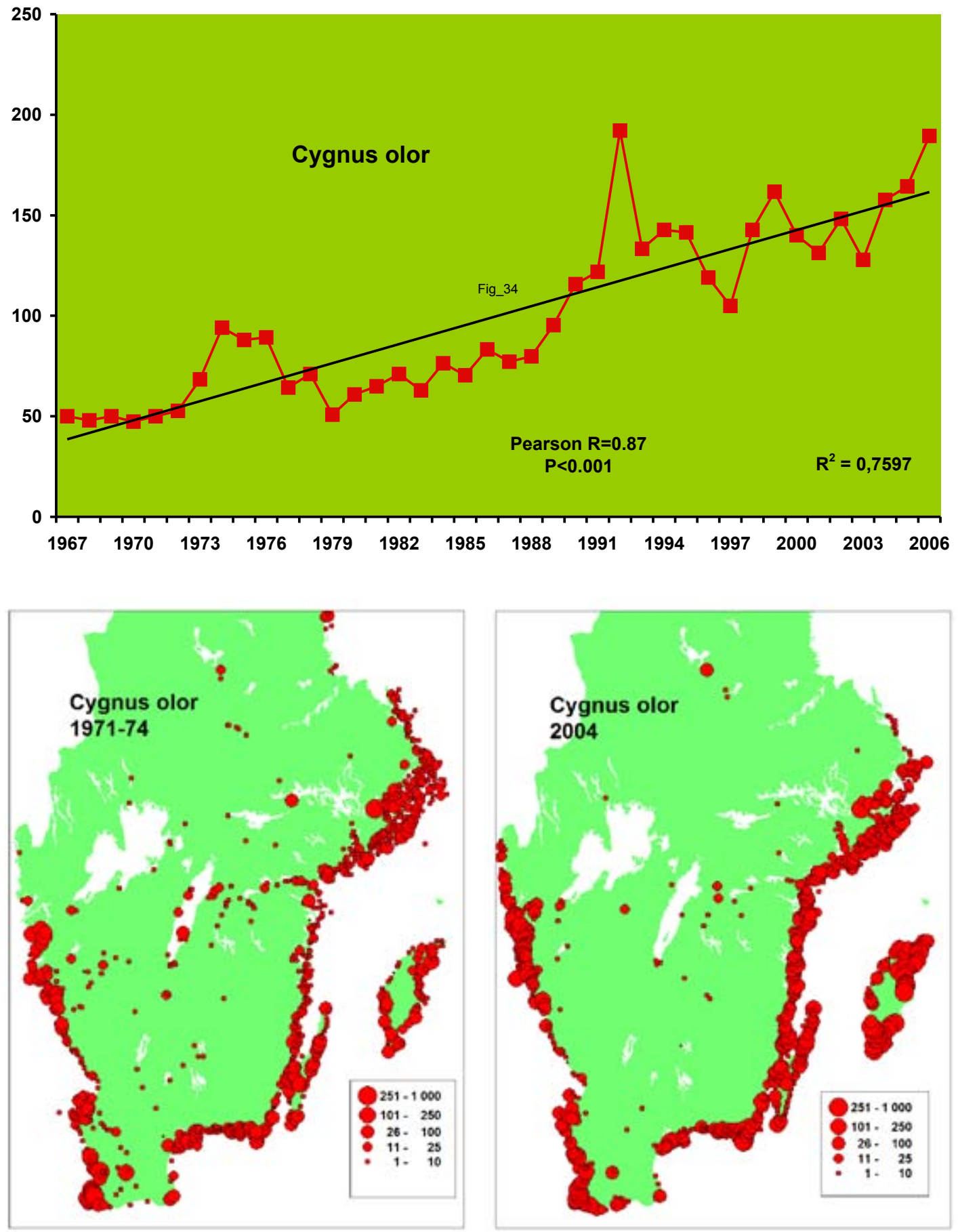

Figure 34. Mute Swan Cygnus olor. Midwinter population indices and distribution maps. Knölsvan Cygnus olor. Populationsindex och utbredningskartor för midvintern. 

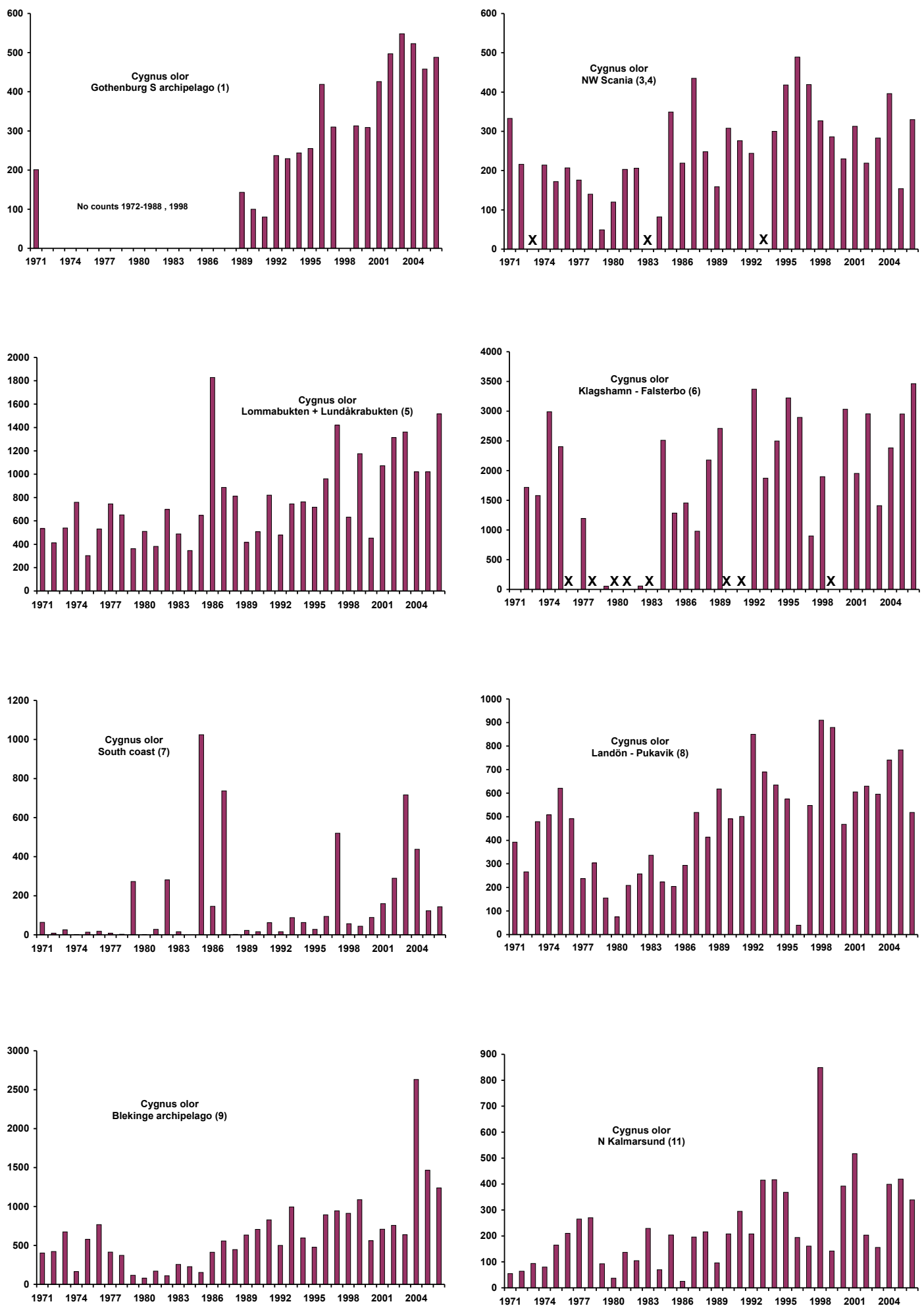

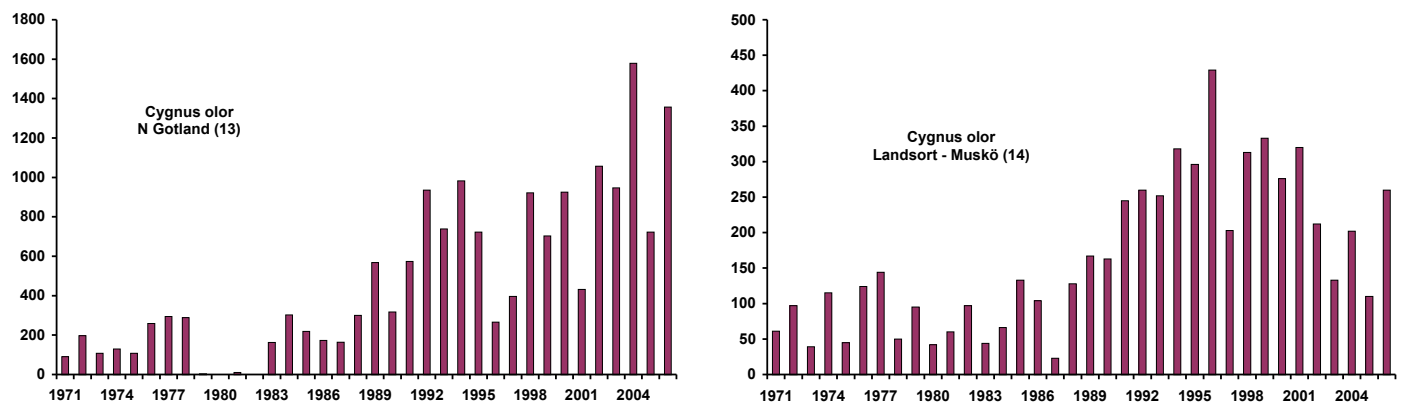

Figure 35. Counts of Mute Swan Cygnus olor in coastal reference areas (Figure 3) in Sweden in January 1971-2006. X = No counts in the area this year.

Räkningar av knölsvan Cygnus olor inom olika referensområden vid kusterna (Figur 3) i Sverige januari 1971-2006. X= räkningar saknas detta år.

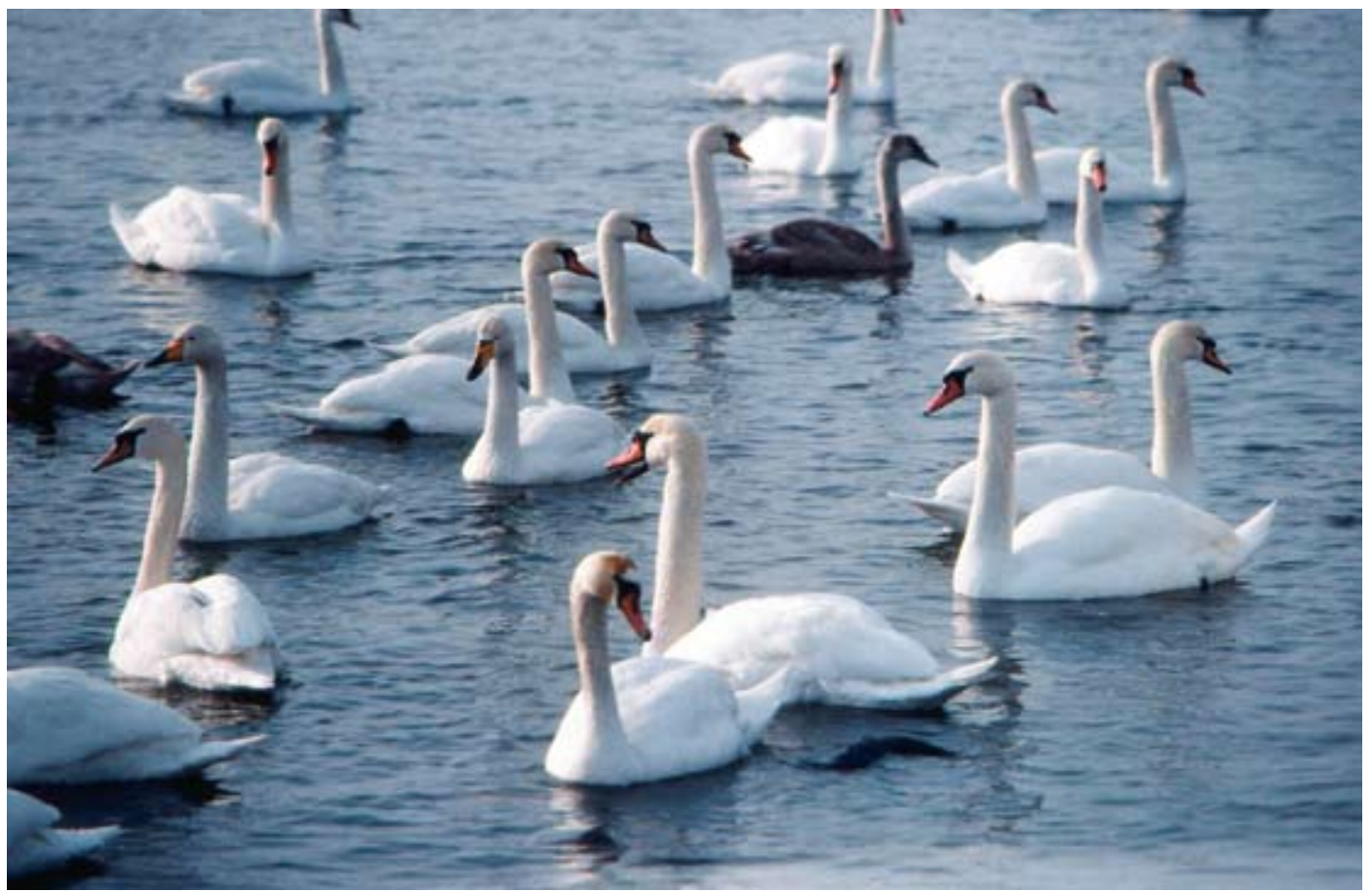




\section{Whooper Swan Cygnus Cygnus}

The midwinter indices for the Whooper Swan did show an increasing trend (Figure 36), but that increase was much smaller than indicated by special swan surveys in later years. In recent years (mainly since 1990) there has been a marked change in the habitat selection of the Whooper Swans wintering in Sweden and other parts of Europe, the swans to a larger extent feeding in fields far away from the wetlands that are now in many cases only used for roosting (Nilsson 1997, 2002, Laubeck et al. 1999). It was therefore not longer possible to follow the development in the wintering Whooper Swan population properly by the traditional Midwinter Counts that cover water areas.

Special Whooper Swan surveys were undertaken in Sweden as in other European countries in 1995, 2000 and 2005 and will be continued at five year intervals. Before 1990 most Whooper Swans remained on traditional habitats so the count in January 1971 can be considered a total count of the winter population, 2100 Whooper Swans being found. The same applies to 1988-1989, when
4000 were found. In January 2004, 1485 Whooper Swans were counted in the fully covered coastal areas, with an additional 1500 on the inland sites covered. The inland coverage of Whooper Swans in 2004 was very incomplete /see above!) and instead I use the estimate of 9500 Whooper Swans from the 2005 special count, which was undertaken in similar weather conditions. At the two special Whooper Swan counts in January 1995 and 2000 about 8000 Whooper Swans were found each year.

The Whooper Swan is a well-spread wintering waterbird in south Sweden with small numbers seen on a large number of sites both inland and at the coasts (Figure 36). The Whooper Swan was found in flocks all along the west coast of the country, whereas it in the Baltic was confined to the open coasts of Öland and Gotland and the archipelago areas of Blekinge, which has another character with Zostera meadows compared to the archipelagos further north on the Baltic coast. Inland, larger flocks were mostly found in the western parts of the country, especially in province of Scania, but also in the larger river valleys further north in the west of the country.

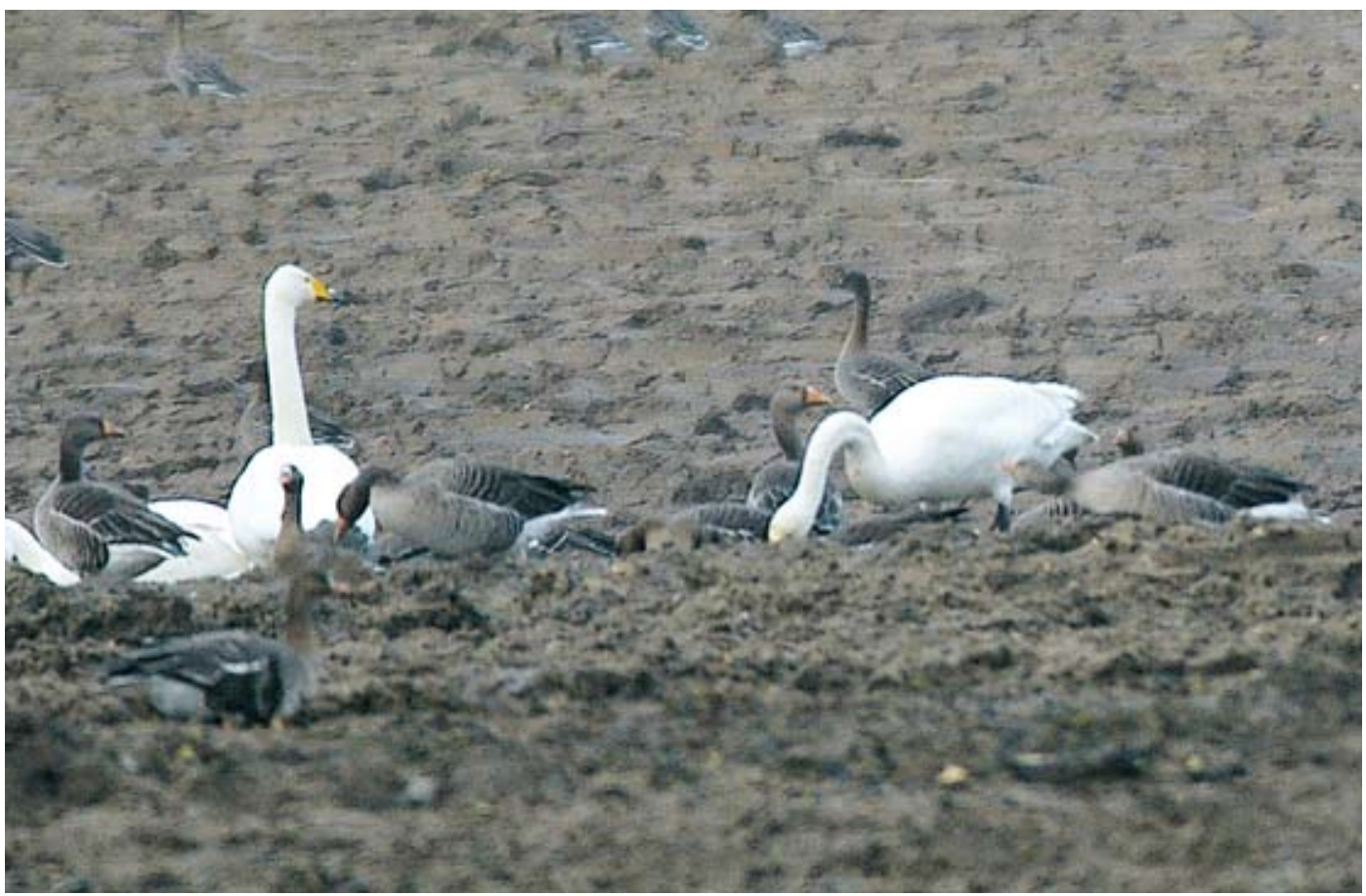



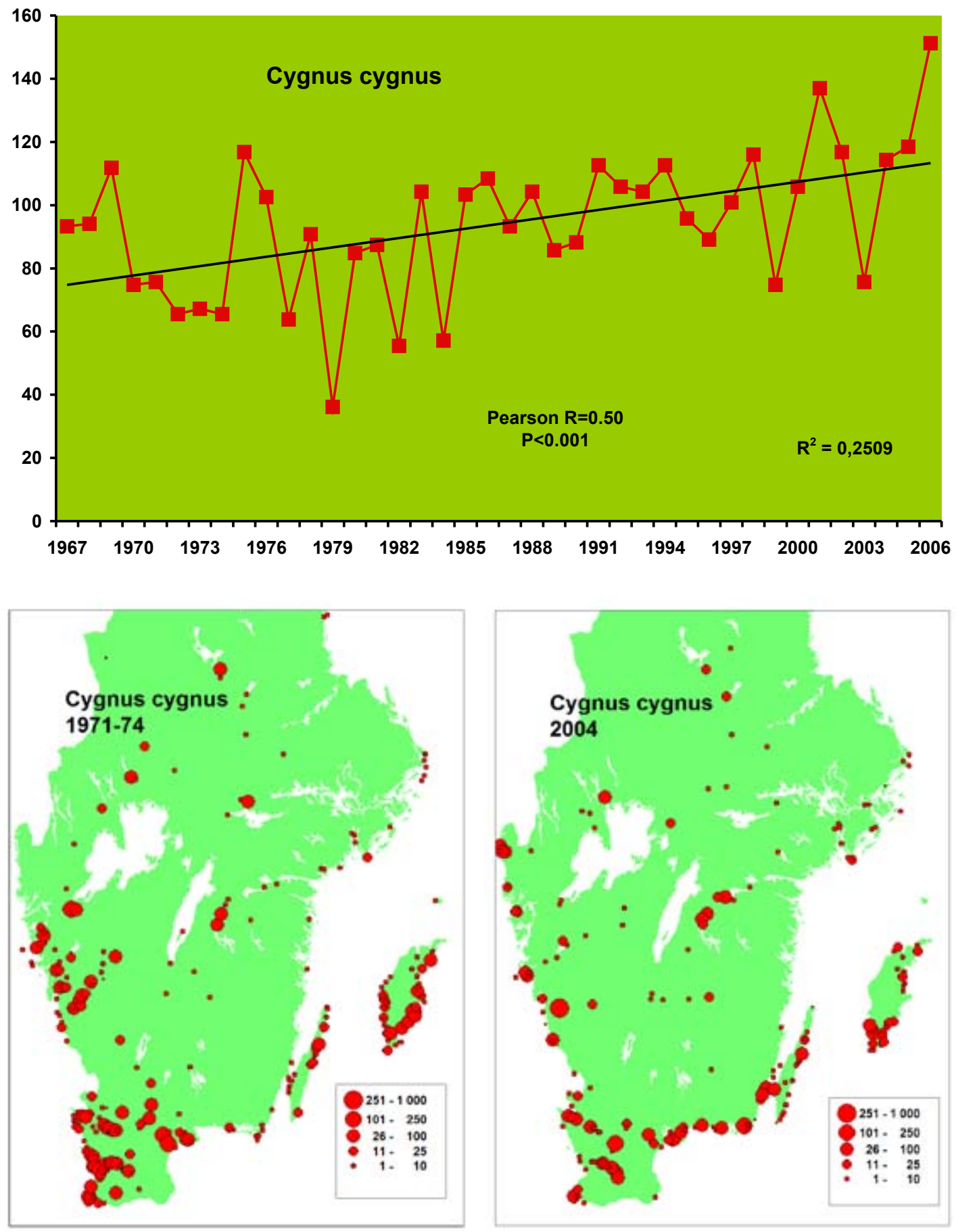

Figure 36. Whooper Swan Cygnus cygnus. Midwinter population indices and distribution maps. Sångsvan Cygnus cygnus. Populationsindex och utbredningskartor för midvintern. 


\section{Coot Fulica atra}

The Coot index showed a highly significant overall long-term trend (Figure 37). However, the index series can be split into different parts showing different tendencies. Counts of Coot were first started in 1968, when the index was on a low level. During the mild winters of the 1970s there was a marked increase to a high index value in January 1978. January 1979 was a very hard ice-winter and the wintering population crashed, many sites lacking wintering Coots altogether in the following years. A series of cold winters followed: 1982, 1985 and finally 1987 and the index was generally very low during the 1980s. From 1990 the indices started to increase and the highest value during the whole series was reached in January 2006. There were however quite marked fluctuations between different years during the latter increase phase.

The Coot was a common wintering bird along the coasts of south Sweden, although there were marked changes in numbers and distribution between the different years (Figure 37). There was a marked concentration of larger flocks to the Öre- sund region and the archipelago of Blekinge (Figure 37). Even if the total number of Coots counted in 1971 was much lower than in 2004, the species was more spread especially at the east coast in the seventies compared to 2004.

In January 1971 the country-wide survey found 4000 Coot along the Swedish coast with a few seen inland. In January 2004 15,600 were actually counted, but taking inland sites into account a minimum 18,000 Coots were estimated to be present in the country at the time of the survey.

Most reference areas showed the same pattern as the national index (Figure 38), but there was some variation between the different areas and regions. Thus the two main reference areas in north-west Scania $(3,4)$ showed high counts in the years before the crash, but there was only small numbers counted here again until in the last few winters, but numbers were then still far below those in the 1970s. On the south coast (7) of Scania, on the other hand, numbers were low in most years before 1992, but then they have been increasing. As in most other species, Kalmarsund (11) showed mostly fluctuations related to the ice situation in the area.

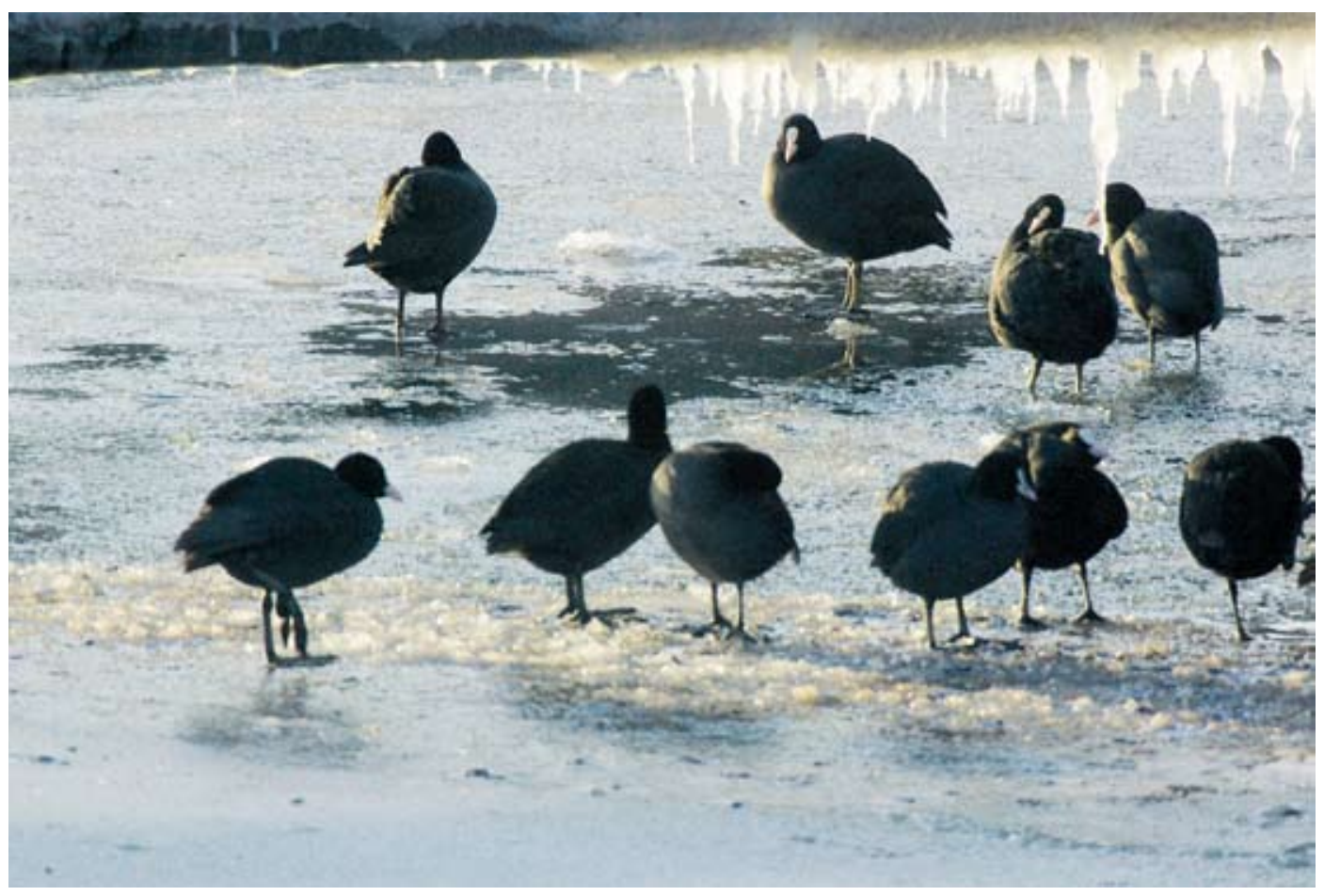



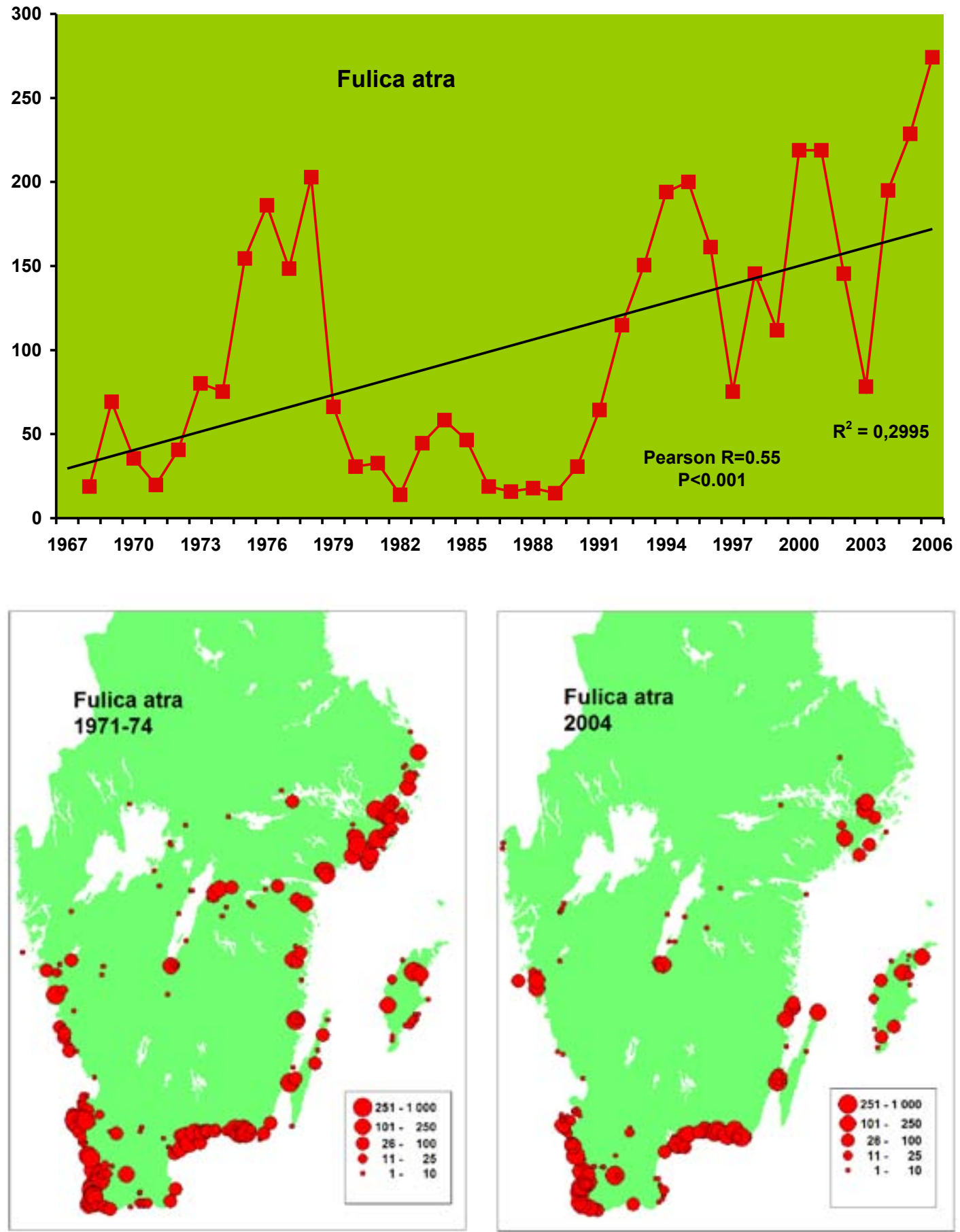

Figure 37. Coot Fulica atra. Midwinter population indices and distribution maps. Sothöna Fulica atra. Populationsindex och utbredningskartor för midvintern. 

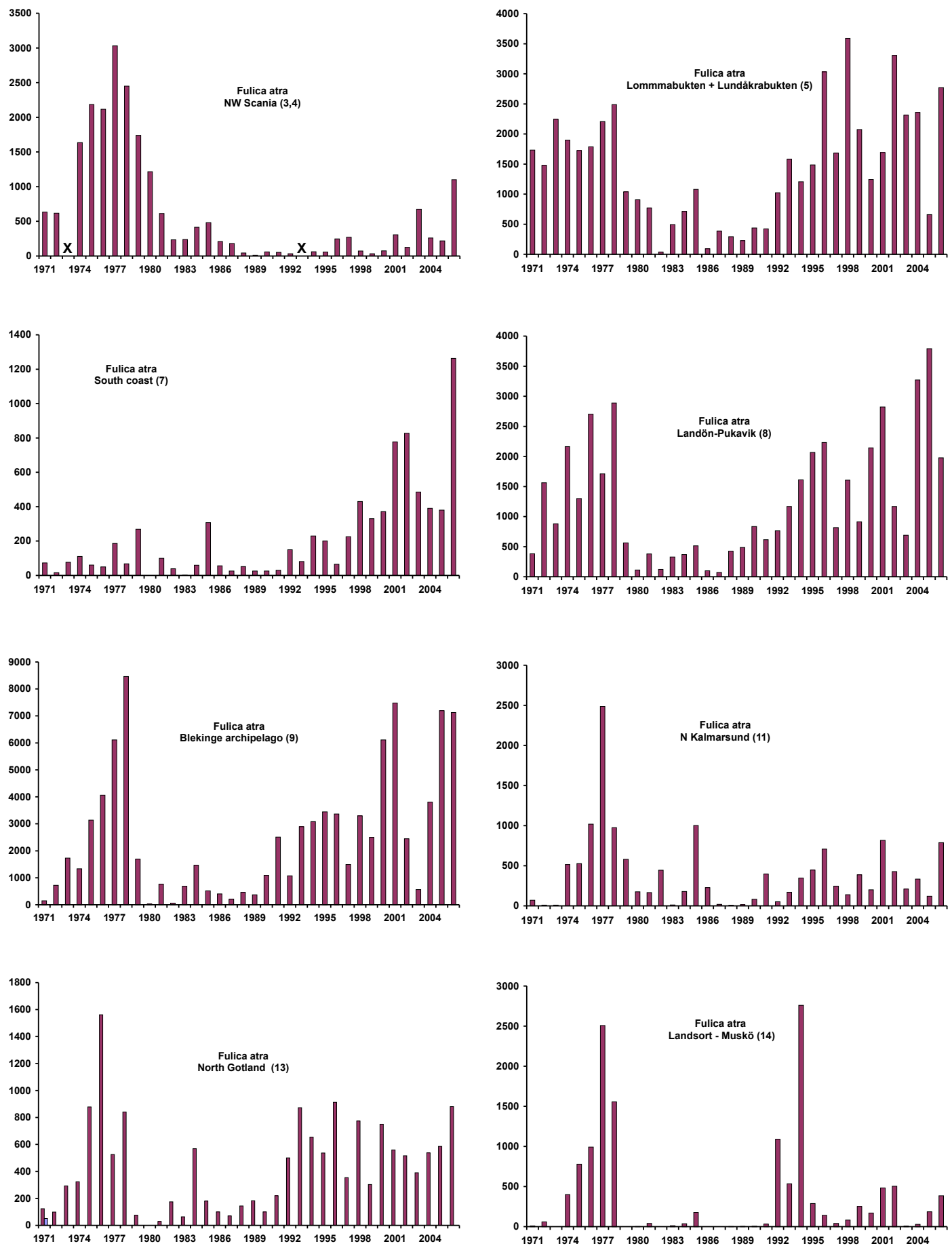

Figure 38. Counts of Coot Fulica atra in coastal reference areas (Figure 3) in Sweden in January 1971-2006. X= No counts in the area this year.

Räkningar av sothöna Fulica atra inom olika referensområden vid kusterna (Figur 3) i Sverige januari 1971-2006. X= räkningar saknas detta år. 


\section{Great Crested Grebe Podiceps cristatus}

The number of Great Crested Grebes was low during the first years (Figure 39, 40). The situation was the same until 1990, with small numbers seen along the coasts mostly in southernmost Sweden. In 1971, single individuals and small groups were found dispersed along the coasts but there were no larger flocks. In 2004 the situation was different and flocks were found, mostly in Scania but also in the provinces of Blekinge, Öland and Gotland (Figure 39). Inland there have been a few occurrences of small numbers with the exception for Lake Vättern. This large and deep lake has been at least partly ice-free in most winters except the coldest, but the coverage of the counts have been restricted, so the numbers wintering here are certainly underestimated.
At the country-wide survey in January 2004, 4294 were actually counted at the coasts of south Sweden, but inland coverage was inadequate for the calculation of wintering totals. About 100 were counted on a few sites on Lake Vättern. With similar densities in uncovered areas here the population on this lake could have been more than 500, so a reasonable national estimate would be around 5000-5500. During mild winters in the last few years up to 1000 Great Crested Grebes have been counted on inland index sites in Scania.

Then numbers started to increase in the reference areas around 1990 (Figure 40) and in 2004, the year of the last country-wide survey more than 3000 were counted on these areas.
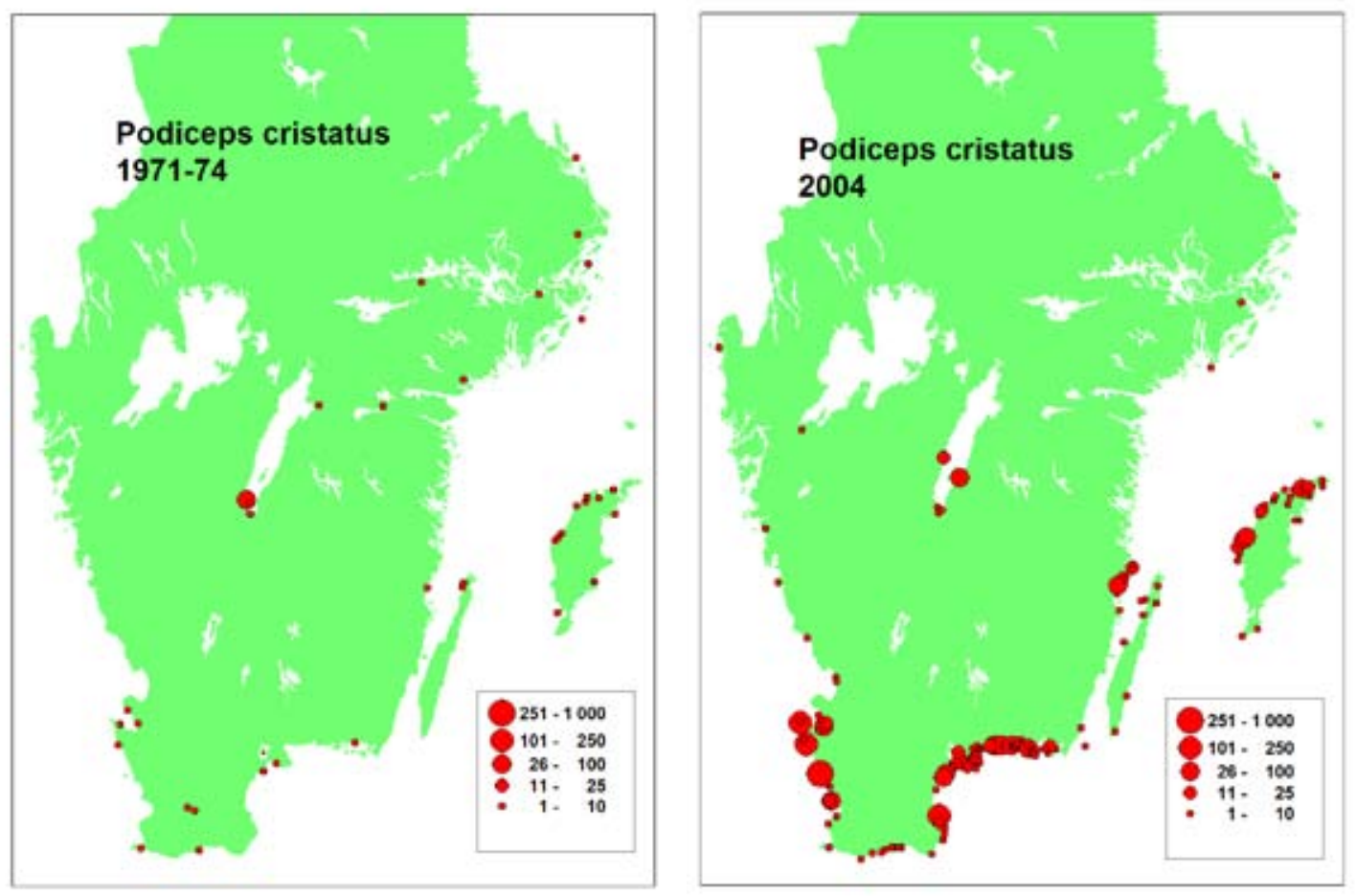

Figure 39. Midwinter distribution of Great Crested Grebe Podiceps cristatus in Sweden based on the country-wide surveys in 1971-1974 and 2004.

Midvinterutbredning för skäggdopping Podiceps cristatus Sverige baserad på de landsomfattande inventeringarna 1971-1974 och 2004. 


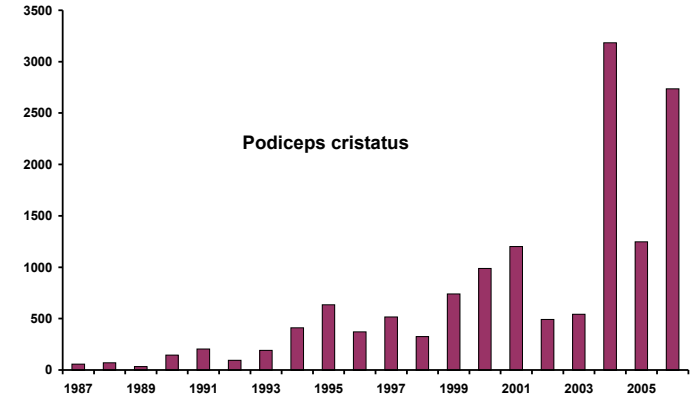

Figure 40. Annual total counts of Great Crested Grebe Podiceps cristatus on all coastal reference areas (Figure 3) in Sweden in January 1987-2006.

Arliga totalsummor av skäggdopping Podiceps cristatus på samtliga referensområden vid kusterna av Sverige (Figur 3) januari 1987-2006.

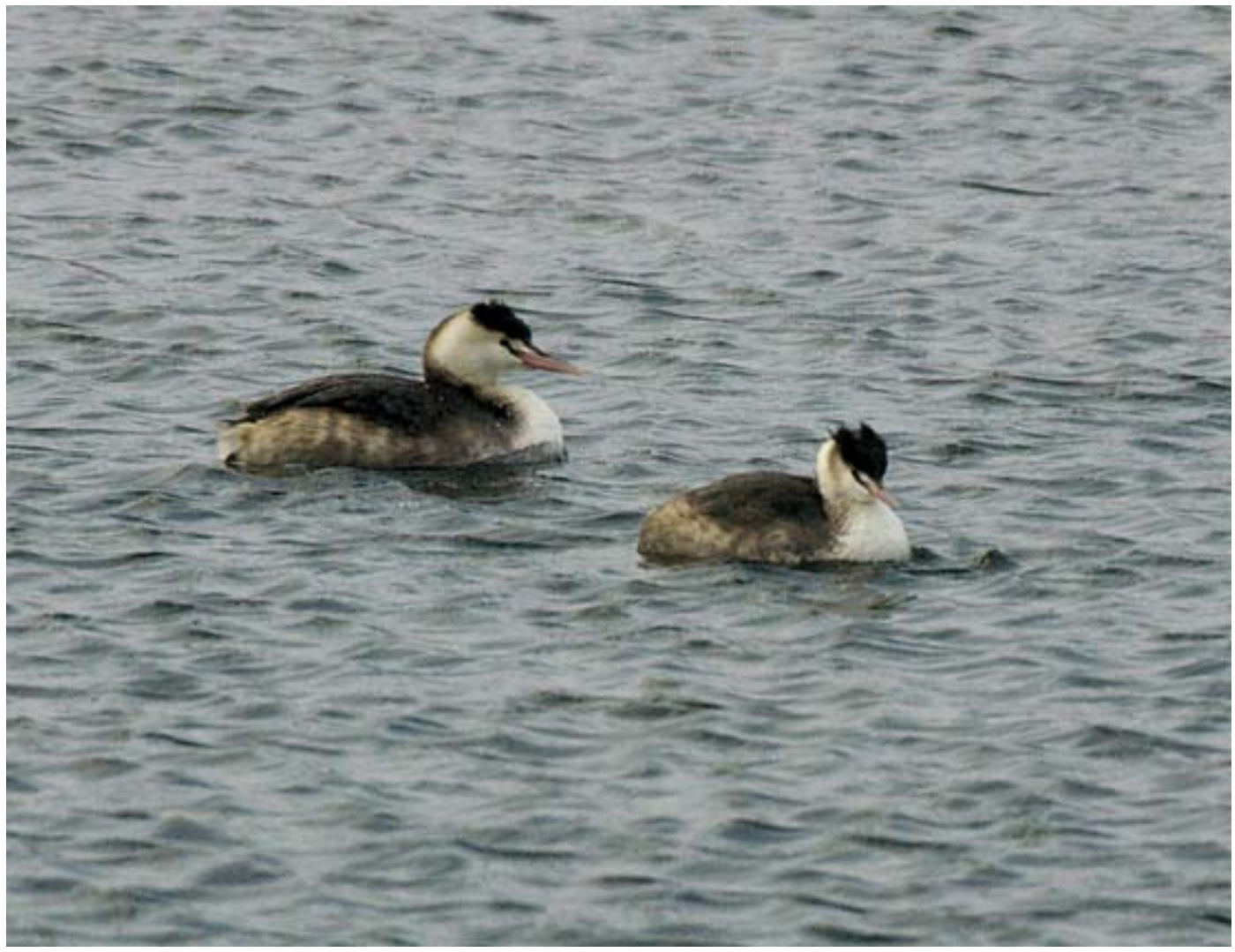




\section{Grey Heron Ardea cinerea}

Small numbers of Grey Heron have been a regular feature in the Midwinter Counts since the start. The Heron was widespread in small numbers both inland and at the coasts (Figure 41). During the first years most coastal herons were found in Scania and on the west coast, but during the 2004 survey, they were also found on the east coast north to Kalmarsund, including Öland and Gotland. Herons were also well spread inland, more so in 2004 than in 1971-1974.

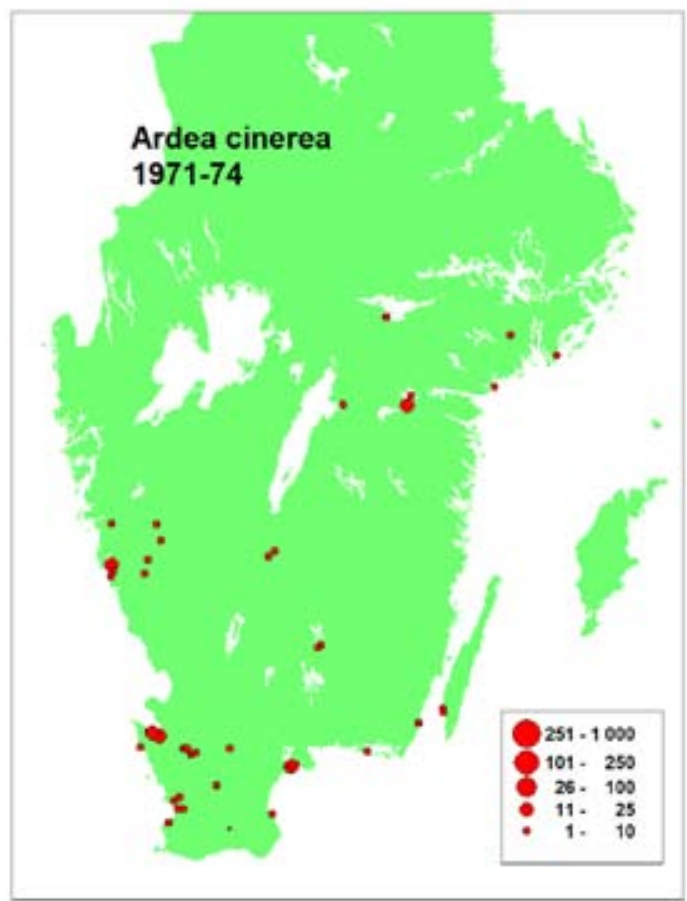

It is difficult to estimate the total wintering population of a species as widespread as the Heron, so the 1000 noted in Table 2 may be an underestimate. Close to 500 were found in the full cover counts of the coasts. In addition to this, 200 were counted inland, where the coverage of smaller inland waters was not sufficientyly good to cover more than a fraction of the suitable sites. Since 1991 more than 400 herons have been found in the reference areas during most winters (Figure 42).

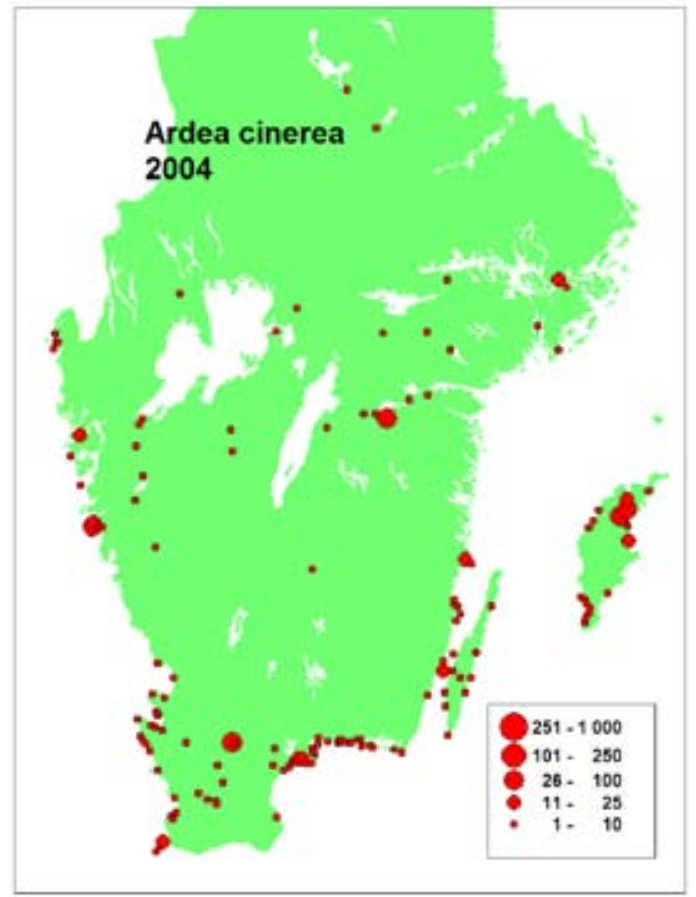

Figure 41 Midwinter distribution of Grey Heron Ardea cinerea in Sweden based on the country-wide surveys in 1971-1974 and 2004.

Midvinterutbredning för häger Ardea cinerea Sverige baserad på de landsomfattande inventeringarna 1971-1974 och 2004.

Figure 42 Annual total counts of Grey Heron Ardea cinerea on all coastal reference areas (Figure 3) in Sweden in January 1987-2006.

Arliga totalsummor av häger Ardea cinerea på samtliga referensområden vid kusterna av Sverige (Figur 3) januari 1987-2006.

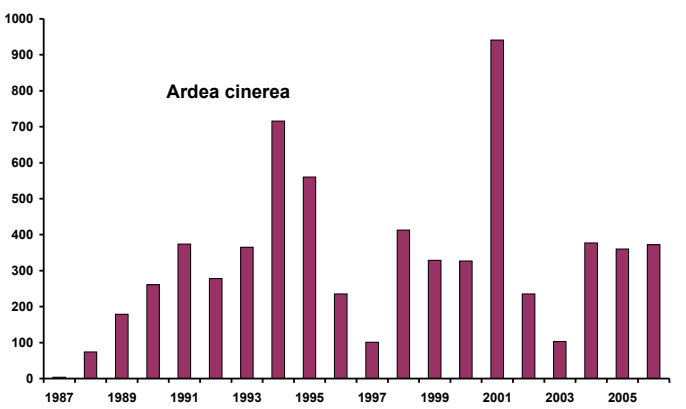




\section{Cormorant Phalacrocorax carbo}

During the winter, the Cormorant is a wide-spread species along the coasts of south Sweden (Figure 43 ), in the archipelagos mostly occurring in the outer zone. On the west coast the species occurs along the entire coast. During the country-wide survey in 1971 only few Cormorants were counted in the southern part of Öresund. The map also show few observations from the northern part of Bohuslän, but this might be due to methodological problems as part of the Cormorants may have been overlooked when fishing in the water. At the survey in 2004 the Cormorants were wide-spread all along the west coast.

The Cormorants in the Baltic were also concentrated to a few areas during the survey in January 1971: Blekinge, eastern Gotland and parts of the southern Stockholm archipelago. In January 2004 they had spread and Cormorants were seen all the way south to the middle part of Kalmarsund.

The total number of Cormorants was estimated to be at least 12,000 in January 2004, probably a little more as there was a gap in the coverage of the outer archipelago of Stockholm. In 1971, there were only about 1100 Cormorants. It may be mentioned in this context that there has been a very large flock of Cormorants in the Öresund between Denmark and Sweden, which in some winters have amounted to 10,000 individuals (Bengtsson 1999, 2000). This flock was not seen during the 2004 survey and is not included in the estimate for that winter.
As the Cormorants in the Baltic archipelagos was mostly confined to the outer zone, which was poorly covered in the annual index counts and as there waere few areas covered in Bohuslän before 1987 , it is not been possible to calculated national midwinter indices for the species. On the reference areas the total increased from 1000 in 1987 to about 4000 in 1991 (Figure 44), fluctuating around this level with the exception of appreciably higher counts being obtained in 1993-1995.

Longer time series are available for some coastal reference areas (Figure 45). Counts in southern Kattegat (2-4) showed marked variations between years, but generally the tendency was increasing. The number of wintering Cormorants in Lommabukten and Lundåkrabukten (5) in central Öresund has normally been quite low, showing counts of up to 300 wintering Cormorants in the years before 1981 and after 2000 and normally less than 100 in the years between. In the Blekinge archipelago (9) few Cormorants were wintering before 1991, but in recent years between $600-1000$ have been wintering here. The Landsort-Muskö area (14) in the southern part of the Stockholm archipelago is the only area with a long time-series including Cormorant habitat in the east coast archipelagos. Up to 200 were counted here in the mid seventies with one exceptionally high count in 1979. During the 1980 s the Cormorants were more or less absent in winter but from 1992-2006 normally around 200 were found wintering here.

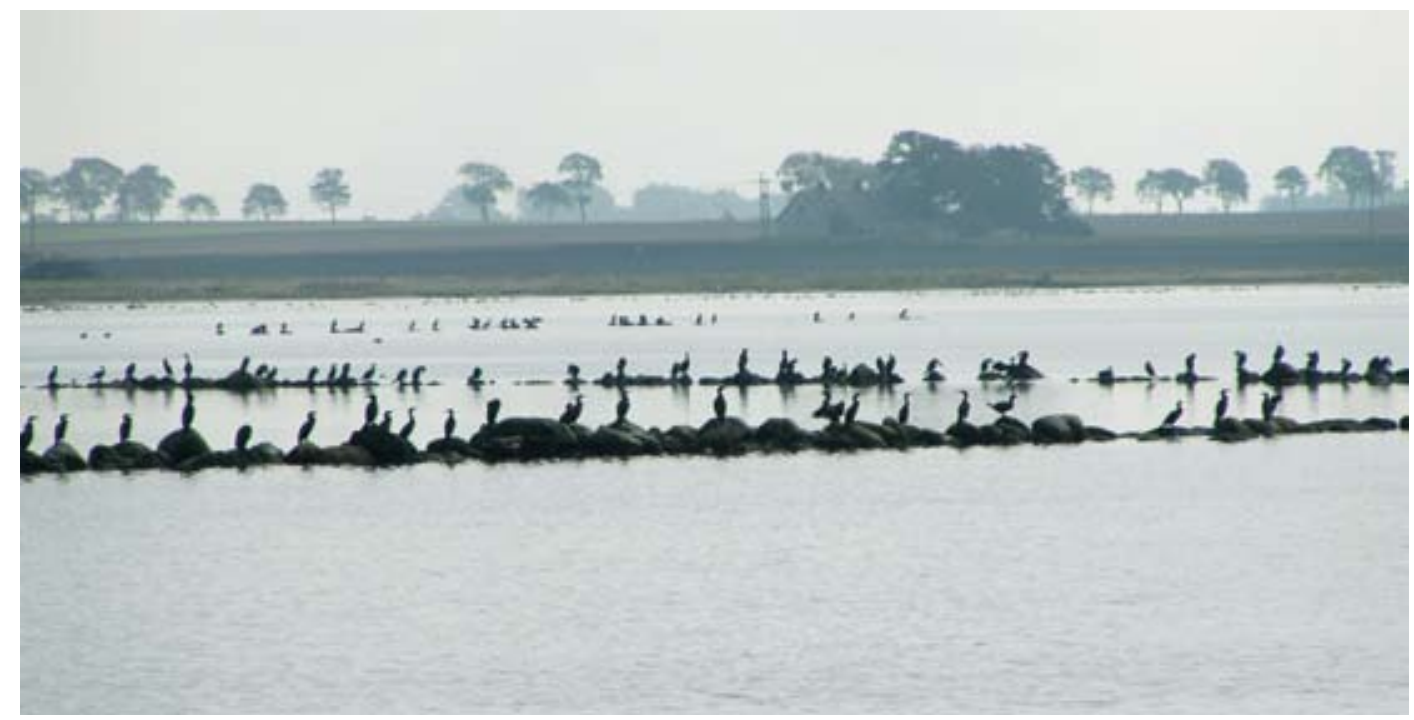



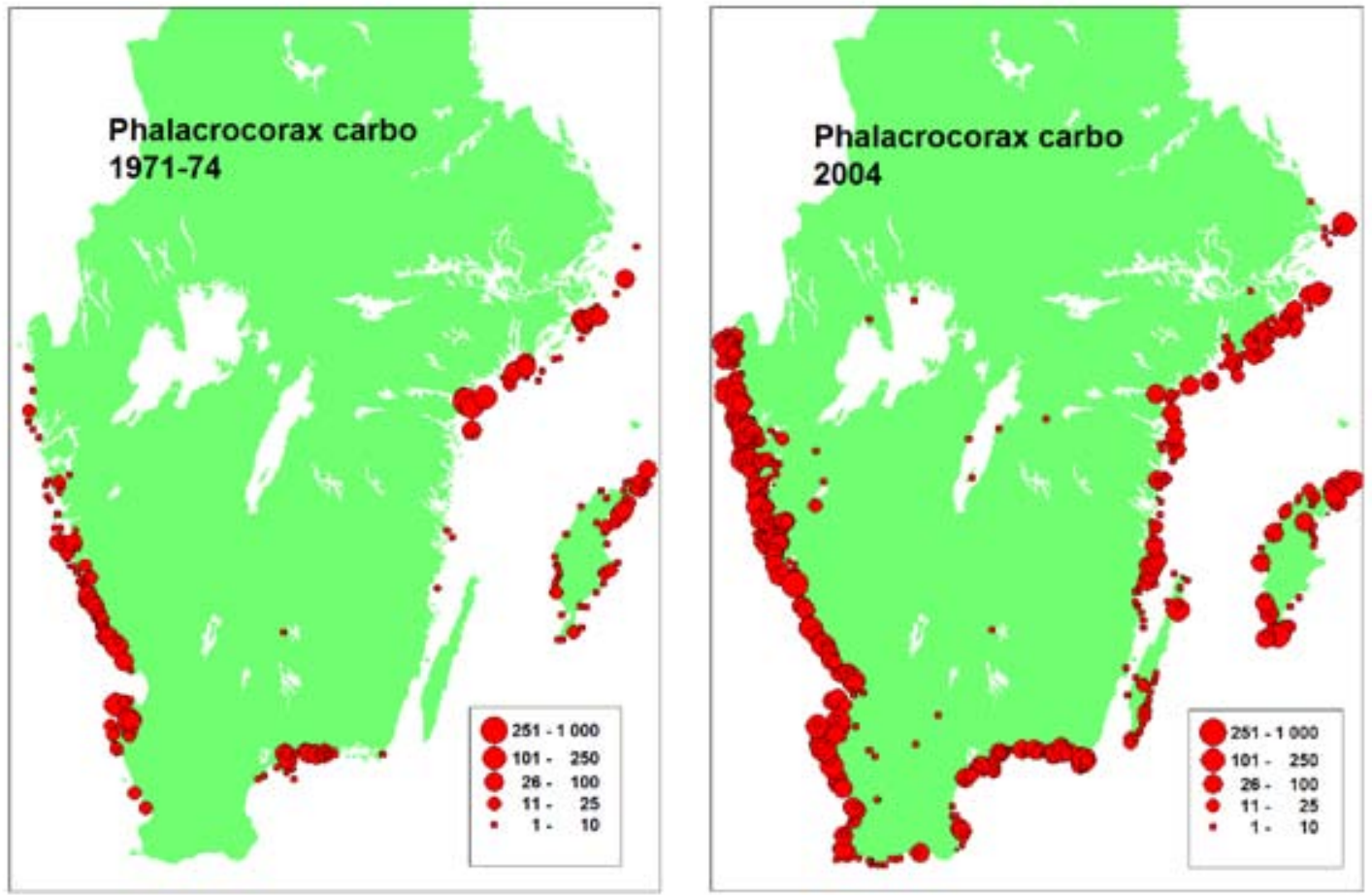

Figure 43. Midwinter distribution of Cormorant Phalacrocorax carbo in Sweden based on the country-wide surveys in 19711974 and 2004.

Midvinterutbredning för storskarv Phalacrocorax carbo i Sverige baserad på de landsomfattande inventeringarna 1971-1974 och 2004

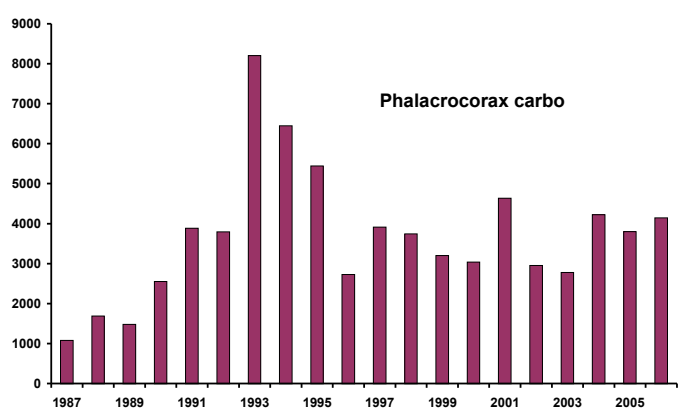

Figure 44. Annual total counts of Cormorant Phalacrocorax carbo on all coastal reference areas (Figure 3) in Sweden in January 1987-2006.

Arliga totalsummor av storskarv Phalacrocorax carbo på samtliga referensområden vid kusterna av Sverige (Figur 3) januari 1987-2006.

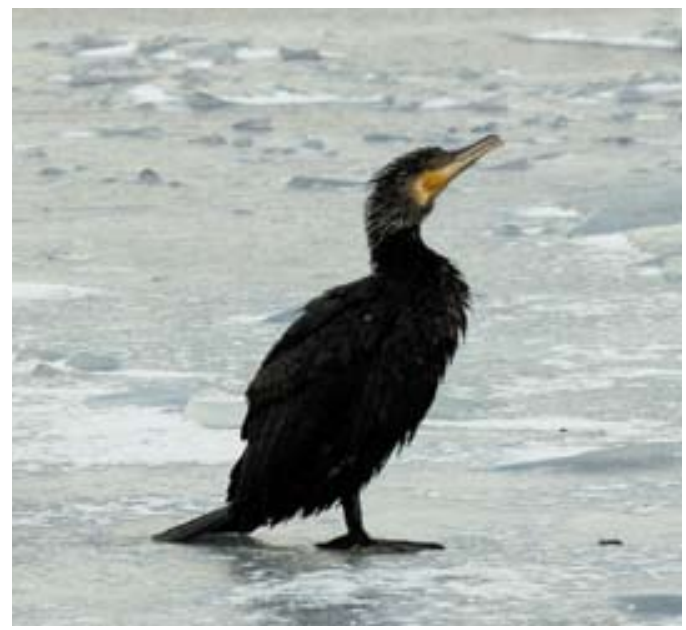

Figure 45. Counts of Cormorant Phalacrocorax carbo in coastal reference areas (Figure 3) in Sweden in January 1971-2006. $\mathrm{X}=$ No counts in the area this year.

Räkningar av storskarv Phalacrocorax carbo inom olika referensområden vid kusterna (Figur 3) i Sverige januari 1971-2006. $X=$ räkningar saknas detta år. 

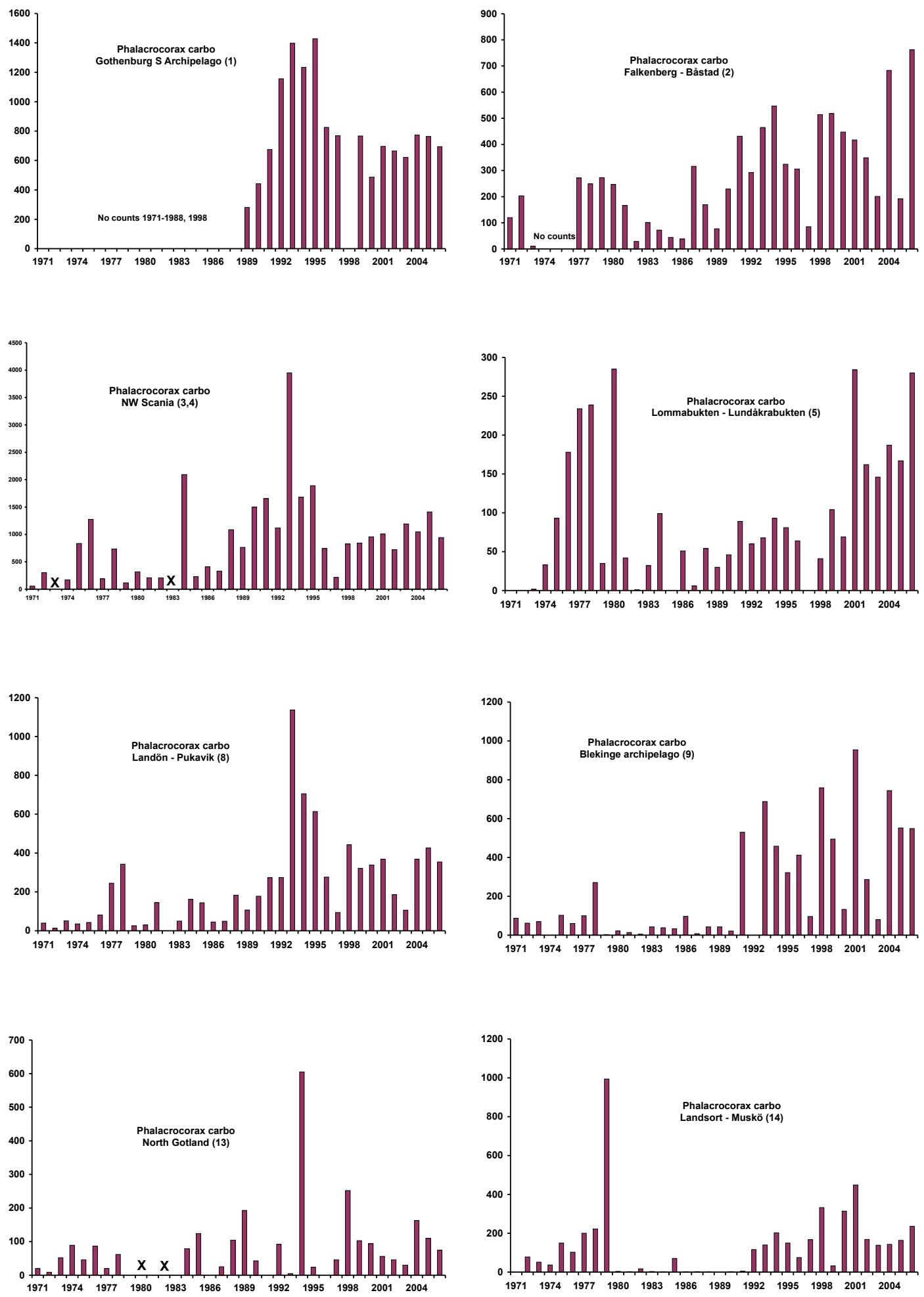


\section{Other species}

In addition to the more common species presented extensively in the species accounts above a number of species were either seen regularly each winter in smaller numbers or more occasionally. For the more regular of these species the totals seen on the coastal reference areas (Figure 3 ) are presented in a series of diagrams (Figure 46).

The Teal Anas crecca was normally a rare bird in Sweden during the winter but in most years small groups or single individuals were reported from some sites at the Midwinter Counts. During the country-wide surveys, 10 Teals were counted in 1971 compared to 320 in 2004. It has been more common in Sweden in winter in relation to the series of milder winters and in some years up to 550 have been counted on the reference areas, the numbers counted on these sites showing marked variation between years (Figure 46).The Pintail Anas acuta is another dabbling duck that has been seen more commonly at the Midwinter Counts in Sweden in recent years. Before 1990 only a few individuals were reported but from 1992 it has increased, and in 2006 more than 200 were counted on the reference areas (Figure 46).

In addition to the duck species discussed above, single individuals or smaller groups of Gadwall Anas strepera, Shoveler Anas clyepata, and King Eider Somateria spectabilis have been counted.

Of the duck species seen in small numbers, the Steller's Eider Polysticta stelleri is of special interest, being a rare species with a restricted distri- bution including a few important sites in the Baltic. In most years only small numbers were seen, but at the country-wide surveys in 1987 and 1989 no less than 46 and 57, respectively, were seen. In later years only few Steller's Eiders have been recorded at the Midwinter Counts.

The Shelduck Tadorna tadorna has been regular in small numbers in the coastal areas of south Sweden in most years except the coldest winters. Total counts for all reference areas have varied between 1 to 250 individuals (Figure 46).

Both the Black-throated Diver Gavia arctica and the Red-throated Diver Gavia stellata occur regularly in small numbers along the coasts of Sweden during midwinter. As they occur dispersed in singles or small group it is difficult to estimate the total populations of divers in Swedish waters. Maximum totals for the reference areas have been 70 for the Black-throated Diver and 200 for the Red-throated Diver (Figure 46). In addition to the two more common species, Northern Diver Gavia immer and White-billed Diver Gavia adamsi have been recorded.

As for the other grebes only small numbers Little Grebe Tachybaptus ruficollis were reported from the first years of Midwinter Counts. Like the Great Crested Grebe, numbers of Little Grebe increased on the reference areas after 1990 (Figure 46) and close to 100 were found at the midwinter count in 2006 (Figure 46). Small numbers of Red-necked Grebe Podiceps griseigena, Slavonian Grebe Podiceps auritus, and Black-necked Grebe Podiceps nigricollis were also seen in most years.

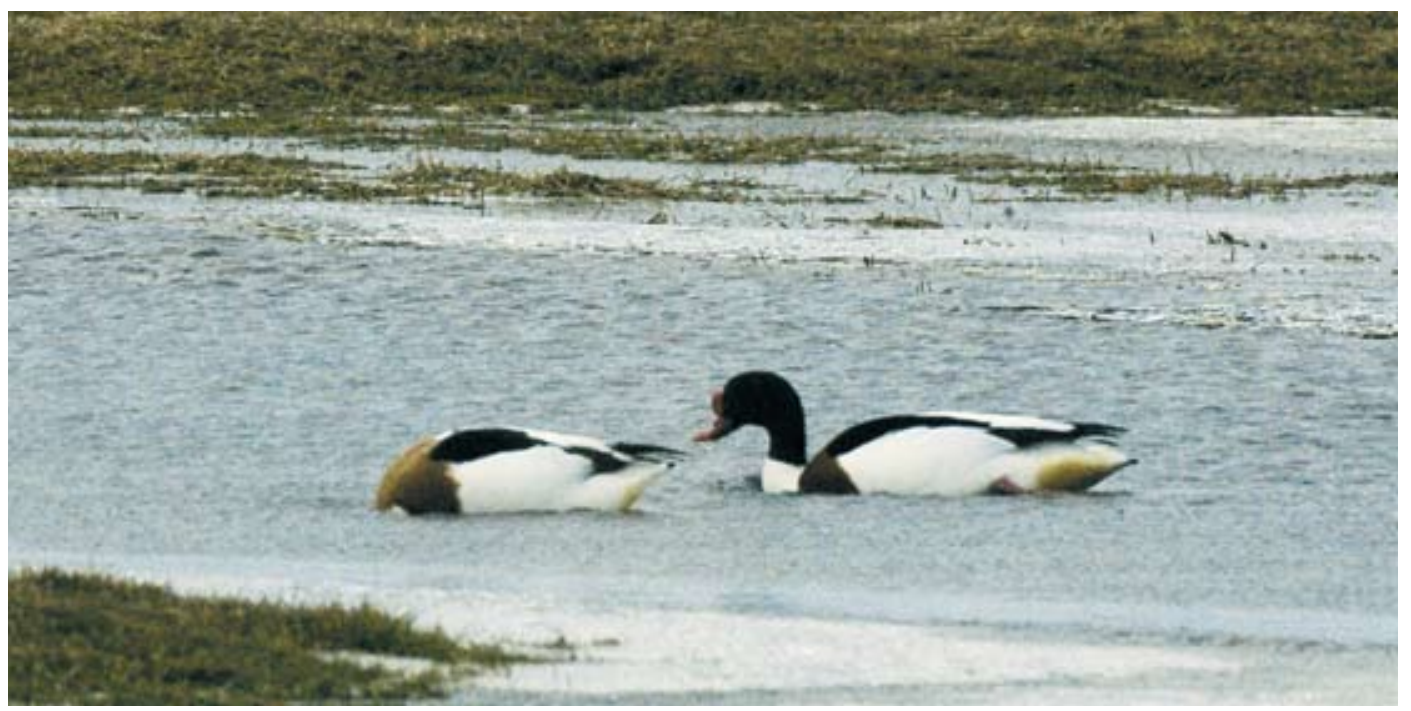



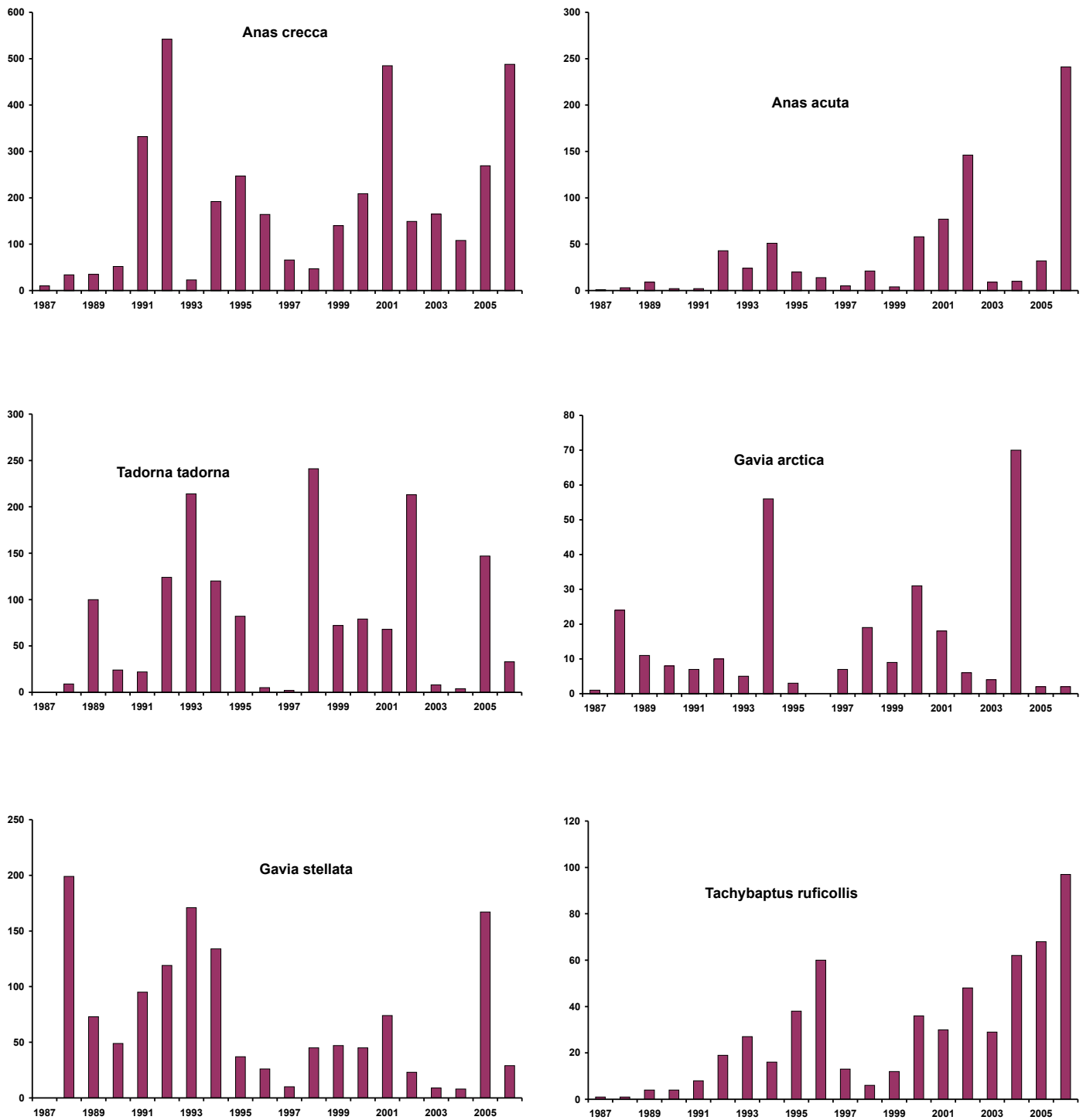

Figure 46. Annual total counts for some less common species on all coastal reference areas (Figure 3) in Sweden in January 1987-2006.

Arliga totalsummor av några mindre vanliga arter på samtliga referensområden vid kusterna av Sverige (Figur 3) januari 1987-2006. 


\section{Discussion}

The importance of Sweden as a wintering area for waterfowl

Situated in northern Europe with the lakes freezing in most years, inland Sweden has not had much of suitable habitat to offer wintering waterbirds. On the other hand the long coast with vast areas of shallow water offers excellent wintering habitats for diving species and some other waterbirds. Even at the coasts, ice coverage has restricted the available wintering areas for the waterbirds. When the counts started most coastal waters north of the Stockholm archipelago were ice-covered and not possible to use for waterbirds, but in the last few years open water has at least in some years been available further north along the Baltic coast.

To put the Swedish wintering areas into a European perspective I have compared the estimates of wintering numbers in Sweden at the country-wide midwinter count in January 2004 with the most recent population estimates for the waterbird populations for NW Europe based on the results of the International Midwinter Counts (Table 6).

Although the Mallard is a common winter species in most parts of south Sweden and at the coasts with a total estimated population in 2004 of 150,000, and even if this estimate should be an under-estimate, it is clear that Sweden is of little importance as a wintering area for the Northwest European Mallard population with an estimated $3 \%$ of the total population using the country in winter. The populations of other dabbling ducks are much smaller.

On the other hand, the shallow areas of the Swedish coast constitute important wintering areas for several diving species as do the offshore banks and other shallow areas at sea in the Baltic. As is apparent from the data presented for the different species, the extent of the winter areas varies much in relation to the strength of the winter.

The commonest wintering species in Swedish inshore waters, the Tufted Duck with an estimated winter population of 230,000 , amounts to $19 \%$ of the total Northwest European population. Sweden is also an important winter area for a number of other diving ducks using inshore waters: the Goldeneye, Eider, Goosander and Smew, for which Sweden harbours between 5 and $10 \%$ of the total Northwest European populations.

Unfortunately, the survey in 2004 did not include the offshore areas of the Baltic Sea. The survey in 1992-1993 (Durinck et al 1994) indicates that more than $33 \%$ of the entire wintering population of Long-tailed Duck in continental Europe is found on Swedish waters, with other important concentrations in Latvian and Polish waters.

Swans have been common as wintering birds in

Table 6. Estimated Swedish winter populations of some waterbird species in relation to the population estimates for Northwest Europe (according to Delany \& Scott 2006).

Uppskattade antal för de svenska vinterbestånden av olika sjöfågelarter i relation till beståndsskattningarna för hela nordvästra Europa (enligt Delany \& Scott 2006).

\begin{tabular}{lrrr}
\hline Species & $\begin{array}{r}\text { Sweden } 2004 \\
\text { Sverige } 2004\end{array}$ & $\begin{array}{r}\text { NW Europe } \\
\text { NV Europa }\end{array}$ & $\begin{array}{c}\text { Sweden per cent } \\
\text { Sverige i procent }\end{array}$ \\
\hline Ant & 150000 & 4500000 & 3.3 \\
Anas platyrhynchos & 320 & 500000 & 0.1 \\
Anas penelope & 5700 & 1500000 & 0.4 \\
Aythya marila & 3200 & 310000 & 1.0 \\
Aythya fuligula & 230000 & 1200000 & 19.2 \\
Aythya ferina & 2750 & 350000 & 0.8 \\
Bucephala clangula & 75000 & 1300000 & 5.8 \\
Somateria mollissima & 50000 & 760000 & 6.6 \\
Mergus serrator & 6000 & 170000 & 3.5 \\
Mergus merganser & 20000 & 266000 & 7.5 \\
Mergus albellus & 3800 & 40000 & 9.5 \\
Cygnus olor & 35000 & 250000 & 14.0 \\
Cygnus cygnus & 9500 & 59000 & 16.1 \\
Fulica atra & 18000 & 1750000 & 1.0 \\
Phalacrocorax carbo & 12000 & 390000 & 3.1 \\
Podiceps cristatus & 4500 & 360000 & 1.3 \\
\hline
\end{tabular}


Sweden. For both the Whooper Swan and the Mute Swan Sweden has an appreciable proportion of the total population of NW Europe, 14-16\%.

The importance of Sweden as a winter area for waterbirds depends on the availability of open water. This is apparent when the fluctuations in wintering waterbird numbers in are analyzed, larger numbers being counted in the milder winters with little ice-coverage. On the other hand many species do not move longer than necessary during the winter, which during colder winters will lead to a concentration of the waterbirds to the few areas available before they eventually evacuate the country during really cold periods with much ice.

\section{Changes and trends in the number of wintering waterbirds}

Analyzing the Midwinter Counts of Waterbirds over a time period, the large annual fluctuations are apparent. To a very large extent these can be related to the weather situation or more specifically the ice situation. In the species descriptions it was very clear for many species that cold winters in many cases led to lower numbers, at least in some regions, especially in the Baltic archipelagos that are the first to freeze over. A closer analysis of the situation however showed that local ice conditions were often more important than just low temperatures during the winter.

The overall trends for the entire 40 year period were significantly increasing for nine out of the ten species for which an index could be calculated. The only species for which no significant trend was found among the "index species" was the Goosander. In addition to the index species, the Wigeon, the Smew and the Great Crested Grebe that were counted in too low numbers in the early years for index calculations showed marked increases during the latter part of the study period. A few hundred Smew were found already during the first years of counts before numbers increased, but the Wigeon and the Great Crested Grebe have established new wintering traditions in SW Sweden.

A close look at the index curves reveals different patterns for different species even if they show significant increases when considering the entire series. The Mallard, the Tufted Duck and the Whooper Swan showed a more or less steady level with fluctuations around the trend line for the first ca 20 years, marked increases starting after the last real cold winter in 1987. The Goldeneye, Pochard and Red-breasted Merganser had low indices at the start of the counts, but already from the start the general trend being an increase with fluctuations around the trend line. The Mute Swan is somewhat between the two groups, the indices being relatively steady for some years but starting to increase already during the 1980 s.

In most cases the total counts from the reference areas show the same general picture as the national indices. In some species there have however been differences. There have been differences in fluctuation patterns between different regions in relation to the hardness of the winter. This was especially clear for the southernmost provinces Scania and Blekinge, where in many years diving ducks left the Blekinge archipelago partly during cold periods, whereas at the same time numbers increased in Scania (cf. Nilsson 2005). For the Goldeneye the long-term trend for the province of Scania was decreasing, whereas the general trend for the country as a whole and for most reference areas further north was significantly increasing. Fewer Goldeneyes were forced south during the more recent milder winters.

The Cormorant is another species for which national indices could not be calculated as most sites in the Baltic are in the outer archipelago, which cannot be covered on an annual basis. Cormorants increased on the reference areas until the 1990s and showed a steady level after that. The country-wide surveys indicated marked increases in all three main coastal divisions used in the analysis here. The Heron was also too uncommon for the calculation of annual population indices, but there was an increase during the late 1980s followed by a more steady level.

For some species it is possible to compare the patterns found in the Midwinter Counts with data from an independent programme. The Winter Point Counts of the Swedish Bird Monitoring (Lindström $\&$ Svensson 2007) has produced sufficient sample sizes for index calculations for a number of species included in the Midwinter Counts. Thus highly significant increasing trends were found for the Heron, Cormorant, Mallard, Tufted Duck, Goldeneye, Goosander, Smew, Mute Swan and Whooper Swan. Weak increasing trends were found for the Pochard and Red-breasted Merganser, whereas no trends were noted in Long-tailed Duck, Eider and Coot. In short, the agreement between the two datasets was very good.

To sum up the discussion of indices and trends so far, it is clear that most wintering waterbirds have increased in Sweden, especially during later years, i.e. after the last really hard winter of 1987. This picture was strengthened by the results from 
the country-wide surveys. The analysis of the Midwinter Counts from a single country as Sweden does not show whether the increase reflects a shift of distribution among the different species as a response to milder winters, or if some populations do also show real changes in numbers. Comparisons with the International Indices based on the Midwinter counts in all participating countries in Europe should give some indications on this matter.

Delany et al (1999) published population indices based on the Midwinter Counts for a number of species up to and including 1996. Indices up to and including January 2001 are available from the webpage of Wetlands International (www.wetlands.org). The international analysis separates between different European regions, of which the Baltic region and Northwest Europe (i. e. the countries bordering the North Sea, not the same as in the Population Estimates cited before).

For the Mallard, the indices from the Baltic region shows the same pattern as the Swedish indices (which form an important part of the Mallard population in this region), the indices fluctuated around a more or less steady level until the eighties, when an increase started. For NW Europe there was a slight decrease during the same period. Thus at least a large proportion of the recent increase in the Swedish indices seems to be due to changes in the winter distribution with more Mallards wintering in Sweden compared to earlier years.

The international indices for the Wigeon in Northwest European population showed a marked increase in the wintering numbers in the region. There are no data available from the Baltic region for index calculations, nor to illustrate whether there has been new wintering traditions established in other Baltic countries as has been the case in Sweden.

For the Tufted Duck, Goldeneye and Red-breasted Merganser, both the Baltic and the North-west European regions showed increasing trends as in Sweden, although the increase in Tufted Duck numbers in the NW European region was modest. The Baltic index for the Pochard increased, but not so marked as in Sweden. On the other hand the northwest European index for the Pochard showed a decrease. In contrast to the Swedish indices, the Goosander indices for the entire Baltic showed an increasing trend, but note that the country-wide surveys in 1971-1973 and 2004 indicate a marked increase between those counts. For the first three species the increasing Swedish indices seems to represent at least partly genuine increases in the populations and not only changes in distribution although part of the increases are most probably due to a northward shift in the winter distribution for these species.

For the Eider, being a seaduck, no international midwinter indices are available. The Swedish indices, being representative for the west coast of the country, indicate a slightly increasing trend over the years although with fluctuations. The country-wide surveys also indicated marked increases from the 1970 s to the present. The overall picture is however not that simple and large scale aerial surveys especially in Danish waters have shown that there has been a marked decrease in recent years (Desholm et al. 2002), which is not apparent in the Swedish winter data. Apparently, the Eiders increased markedly over the entire range up to the early 1990s, but then a marked decrease in wintering numbers occurred. This decrease was not apparent in the Swedish indices.

Both the Mute Swan and the Whooper Swan showed increases in the indices for NW Europe and the Baltic, thus representing genuine population increases, which are at least established for the Whooper Swan (se below!). For the Whooper Swan, see also the special surveys undertaken (Laubek et al. 1999). For the Coot, finally, the Baltic indices started with high values after an increase. as the Swedish one, then followed the marked decrease after the 1979 winter, followed by low indices. The increase phase did however differ between the Swedish and Baltic indices. Indices for northwest Europe showed a slightly decreasing trend.

The indices from the Swedish Bird Monitoring's Summer Point Counts show significantly increasing trends for Cormorant, Heron, Mallard, Eider, Mute Swan and Whooper Swan (Lindström \& Svensson 2007). As seen above, the Midwinter indices for the last four species similarly show increasing trends, whereas increases were indicated for reference areas during the latter part of the study for the Cormorant and the Heron. However, note the general decrease for the Eider in later years (Desholm et al. 2002). The Whooper Swan breeding surveys in northern Sweden showed a more than tenfold increase in numbers between the early seventies and 1997 (Nilsson et al. 1998), the same trend being found for the rest of Sweden too (Arvidsson 1997)).

From the comparisons between the Swedish and international Midwinter Indices (and the Swedish Breeding Bird Survey) it is clear that the population indices and the counts in the reference areas reflect both genuine population increases and changes due to the milder winters in recent years. It 
seems clear that there are genuine increases in the populations of Mallard, Tufted Duck, Goldeneye, Red-breasted Merganser, Mute Swan, Whooper Swan and Cormorant since the start of the counts. The international indices indicate that the European population of Wigeon has increased at the same time as it has colonized Sweden. For the Pochard most changes are probably due to milder winters. In the Goosander and Smew the coverage in the international counts are not good enough to evaluate the Swedish trends. In the Coot finally there seems to be very marked fluctuations caused by heavy mortality in some winters and it is therefore difficult to evaluate the trends.

\section{Changes in winter distribution}

Especially the two country-wide surveys presented here clearly showed changes in the winter distribution of many waterbirds within the country. The most important factor behind the distribution of most species discussed here is the availability of open water. This is important not only for the diving ducks and other diving waterbirds but even for dabbling ducks, such as the Mallard, and the swans.

Over the period of the midwinter counts there has been a marked change in the occurrence of really cold winters with extensive ice coverage in the inner Swedish waters. During the years 1967 1987, five of the winters could be classified as hard ice winters for the diving waterbirds with extensive ice-coverage even along the coasts of southern Sweden, whereas there were no such winters in the latter years, even if there was much ice in these waters occasionally for shorter period. Moreover it has been a trend towards less ice in the archipelagos even during more normal winters.

The diving ducks show markedly different diving abilities (Nilsson 1972, de Leeuw 1997) from the deep diving Long-tailed Duck and Scoters that could feed at depths of up to several tenths of metres to the Pochard that normally dives in relatively shallow water (Nilsson 1972). The two commonest diving ducks in Swedish inshore waters, the Tufted Duck and the Goldeneye normally dive in depths less than $6 \mathrm{~m}$ (Nilsson 1972). Accordingly the diving ducks show very marked differences in their reactions to cold winters with freezing shallow coastal waters from the seaducks that will always find feeding areas in the offshore areas to the most sensitive Pochard with the Tufted Duck and Goldeneye somewhere in between.

Marked changes in the distribution of the win- tering waterbirds were accordingly found, mostly related to the changes in ice-conditions related to the milder winters. Even if part of the increasing trends in the wintering waterbird populations in Sweden reflect true changes in the populations, a large part merely reflects large scale changes in the distribution with more individuals of most species wintering further north. Within Sweden, the most marked increases in the Baltic wintering populations of different waterbirds were found in the archipelagos north of Kalmarsund. Thus there was a tenfold increase in the number of wintering Goldeneyes here from the early 1970s compared with a much more moderate increase for the southern Baltic coast (or decreases in some reference areas). The same tendency was found in the Tufted Duck, whereas the increase in the numbers of an inferior diver such as the Pochard was still mostly restricted to the south, even if smaller numbers appeared further north. These increases in the north are to a very large proportion the effect of the mild winters and much larger areas available for the wintering waterbirds in recent years compared to earlier.

When the counts started in the 1960s the areas to the north of the province of Uppland were considered to be without interest as far as wintering waterbirds were concerned, as the inshore areas here were ice-covered in almost all years. This situation does not apply anymore and appreciable numbers of Goldeneyes and Goosanders have been found wintering in the southern parts of the Bothnian Sea (Axbrink 2004).

Both species of swans wintering in Sweden were found to have increased markedly in population size during the period considered here. The Mute Swan increased in all three major regions, but the increase was more marked in the Baltic archipelagos than in the other areas, certainly an effect of changed distribution. The Whooper Swan also increased, but this was only partly reflected in the midwinter indices (but see the special Whooper Swan surveys in 1995-2005 (Nilsson 1997, 2002)) due to the shift from feeding in traditional water areas to feeding in the fields (Nilsson 1997). In Sweden this habit was mostly restricted to the southern provinces, whereas it was widespread also in Denmark, Germany and the Netherlands. Further north in Sweden, Whooper Swans were still mostly feeding in aquatic habitats.

In addition to the shift in the distribution of wintering waterbirds along the coasts of Sweden there have also been shifts between the coast and inland. During the mild winters open water has been available in inland Sweden to a much higher extent in 
recent years compared to the first half of the counting period. The standard sample of inland sites used for the index calculations have shown higher counts in more recent years, but the coverage does not allow the calculation of accurate numbers of wintering waterbirds such as Tufted Ducks, Goldeneyes and Goosander for inland sites.

Finally, new species established wintering traditions in south Sweden during the study period. When the counts started the Wigeon and the Great Crested Grebe were only counted in single individuals or small groups, but in the latter part of the period both species were regularly wintering in good numbers, probably related to the mild winters.

\section{The effect of hard winters}

The cold ice-winters, especially in 1970, 1979, 1982, 1985 and 1987, led to marked changes in the distribution of wintering waterbirds in Swedish and neighbouring waters with low indices and/ or counts in the same winters for several species. However, indices were generally back to normal levels in the following mild winters.

For one species, the Coot, the cold winter in 1979 apparently led to a population decrease that persisted, with low September and January indices for a number of years in the 1980s and the indices did not show a recovery until the 1990 s, i.e. after the last very hard winter. The same decrease among Coots was found in the international indices for the Baltic (Delany et al 1999). The decrease in the Coot population in Sweden after the 1979 winter was also apparent in the breeding population in Sweden (Svensson 1981). From work in the Netherlands and the Czech republic (Cavé \& Wisser 1983, Fiala 1978) it is known that the Coot is sensitive to cold periods with ice, which can lead to heavy mortality among the wintering birds.

In the Mute Swan, heavy mortality occurred in Denmark during the 1970 winter, the mortality rate being about $30-35 \%$ compared to the normal 7-15\% (Andersen-Harild 1981). There was no marked decrease in the Swedish midwinter indices after the 1970 winter, whereas such effects were found in 1979 and 1982.

For no other species were there any clear indications of highly increased mortality during the cold winters. It may be that the waterbirds could find enough open areas for feeding but it is also probable that the timing of the cold periods was of importance. An early cold period will induce more migration to more benign areas and lower mortality. After the last really cold winter, in 1987, the following mild winters caused waterbirds to winter further north than normal and any effects on the mortality by the cold winter would be concealed in the indices. In this respect it should finally be mentioned that during the very hard winter 1962/1963 when ice-coverage in Swedish waters and other northern European areas was more marked than in any of the later cold winters, increased mortality was recorded in many European countries including Britain (Boyd 1964).

Hard winters can also have other effects on the wintering populations even if they do not lead to increased mortality (Boyd 1964, Andersen-Harild 1981). The hard winters with bad feeding conditions might lead to lower weights and accordingly lowered conditions which for the Mallard and Eider was found to influence future breeding performance (Milne 1976, Owen \& Cook 1977). For the Whooper Swans staging in Sweden it was found that fewer pairs returned with young in the autumn after a hard winter (Nilsson 1979).

\section{Acknowledgements}

The Swedish Midwinter Counts are supported by grants from Naturvårdsverket (the Environmental Protection Agency) and form part of their National Monitoring Programme. Additional financial support has also been obtained from the Swedish WWF for some years. The counts could not have undertaken without the great "army" of voluntary duck counters that have covered their counting sites for many years even during very harsh conditions. My sincere thanks are due to all these enthusiasts. During the first years of duck counting the project was supported by the Swedish Airforce, taking care of the aerial surveys without any costs for flying time. I am very grateful to the Swedish Coast Guard that allowed duck counters onboard their patrol ships during about 100 days of duck counting along the Swedish coast.

\section{Referenser}

Andersen-Harild, P. 1981. Population dynamics of Cygnus olor in Denmark. Proc. Second Int. Swan Symposium, Aapporo 1980, pp 176-190.

Arvidsson, B. 1987. Sångsvanens Cygnus cygnus utbredning och populationsstorlek i Sverige. Vår Fågelvärld 46: 248-255.

Atkinson-Willes, G. L. 1963. Wildfowl in Great Britain. Monographs of the Nature Conservancy. 3. Her Majesty's Stationery Office, London.

Atkinson-Willes, G. L. 1969. The midwinter distribution of Wildfowl in Europe, northern Africa and southwest Asia, 1967 and 1968. Wildfowl 20: 98-111. 
Axbrink, M. 2004. Midvinterinventering av kustfåglar i Hälsingland. Fåglar i X län 27: 137-141.

Banks, A.N., Collier, M.P. Austin, G.E., Hearn, R.D. \& Musgrove, A.J. 2006. Waterbirds in the UK 2004/05. The Wetland Bird Survey. BTO/WWT/RSPB/JNCC, Thetford.

Bengtsson, K. 1999. Ökande antal övervintrande mellanskarvar Phalacrocorac carbo sinensis i Öresund. Ornis Svecica 9: 23-34.

Bengtsson, K. 2000. Ännu en skarvvinter samt ovanligt mycket alkor i Öresund. Ornis Svecica 10: 55-56.

Boyd, H. 1964. Wildfowl and other waterfowl found dead in England and Wales in January-March 1963. Wildfowl Trust Annual Report 15: 20-23.

Cavé, A.J. \& Wisser, J. 1983. Local survival of the breeding birds in a Coot population. Institute for Ecological Research Progress Report 1982: 12-19.

De Leeuw, J. 1997. Demanding divers. Ecological energetics of food exploitation by diving ducks. Van Zee tot Land 61. Lelystad.

Delany, S. \& Scott, D. 2006. Waterbird Population Estimates. Fourth Edition. Wetlands International. Wageningen, the Netherlands.

Delany, S., Reyes, C., Hubert, E., Pihl, S., Rees, E., Haanstra, L. \& van Strien, A. 1999. Results from the International Waterbird Census in the Western Palearctic and Southwest Asia 1995 and 1996. Wetlands International Publication 54. Wageningen, the Netherlands.

Desholm, M., Christensen, T. K., Scheiffart, G., Hario, M., Andersson, Å., Ens, B., Camphuysen, C.J., Nilsson, L., Waltho, C.M., Lorentsen, S.-H., Kuresoo, A., Kats, R.K.H., Fleet, D.M. \& Fox, A.D. 2002. Status of the Baltic/Wadden Sea population of the Common Eider Somateria m. mollissima. Wildfowl 53: 167-203.

Durinck,J., Skov, H., Jensen, F.P. \& Pihl, S. 1994. Important Marine Areas for Wintering Birds in the Baltic Sea. Ornis Consult, Copenhagen, Denmark.

Fiala, V. 1978. Beitrag zur Populationsdynamik und Brutbiologie des Blässhuhns (Fulica atra). Folia Zool. 29: 251-266.

Gilissen, N., Haanstra, L., Delany, S., Boere, G. \& Hagemeijer, W. 2002. Numbers and distribution of wintering waterbirds in the Western Palearctic and Southwest Asia in 1997, 1998 and 1999. Results from the International Watebird Census. Wetlands International Global Series 11. Wageningen, the Netherlands.

Green, M. \& Nilsson, L. 2006. Fågelförekomsten vid Lillgrund, Södra Öresund 2001-2006. En förstudie inför etablering av vindkraft till havs. Report from the Department of Animal Ecology, University of Lund, Lund. Sweden.

Joensen, A. H. 1968. Wildfowl Counts in Denmark in November 1967 and January 1968 - Methods and Results. Danish Review of Game Biology 5(5): 1-72.

Joensen, A. H. 1974.Waterfowl Populations in Denmark 1965-1973. A Survey of the Non-breeding Populations of Ducks, Swans and Coot and their Shooting Utilization. Danish Review of Game Biology 9(1): 1-206.

Laubek, B., Nilsson, L., Wieloch, M., Koffijberg, K., Sudfeldt, C. \& Follestad, A. 1999. Distribution, numbers and habitat choice of the NW European Whooper Swan Cygnus cygnus population: results of an international census in January 1995. Vogelwelt 120: 141-154.

Lindström, Å. \& Svensson, S. 2007. Övervakning av făglarnas populationsutveckling. Arsrapport för 2006. Eko- logiska Institutionen, Lunds Universitet, Lund.

Matthews, G.V.T. 1993. The Ramsar Convention: Its history and development. Ramsar Convention Bureau, Gland, Swizerland.

Milne, H. 1976. Body weights and carcass compostion of the Common Eider. Wildfowl 27: 115-122.

Nilsson, L. 1968. Seasonal Fluctuations in Numbers of Swedish Winter Ducks. Vår Fågelvärld 27: 142-171.

Nilsson, L. 1972. Habitat Selection, Food Choice and Feeding Habits of Diving Ducks in Coastal Waters of South Sweden during the Non-breeding Season. Ornis Scandinavica 3: 55-78.

Nilsson, L. 1975. Midwinter distribution and numbers of Swedish Anatidae. Ornis Scandinavica 6: 83-107.

Nilsson, L. 1976. Monthly counts as a measure of population changes in some species of Anatidae in south Sweden. Ornis Scandinavica 7: 193-205.

Nilsson, L. 1977. November distribution and numbers of Swedish Anatidae. Viltrevy 10: 41-77.

Nilsson, L. 1979. Variation in the production of young in swans wintering in Sweden. Wildfowl 30: 129-134.

Nilsson, 1980a. Änders, svanars och vissa sjöfåglars utbredning och antal i september i södra Sverige. Vår Fågelvärld 39: $277-290$.

Nilsson, L. 1980b. Marsinventeringar av änder, svanar och vissa andra sjöfåglar i södra Sverige 1976-1979. Vår Fågelvärld 39: 149-160.

Nilsson, L. 1980c. De övervintrande alfåglarnas Clangula hyemalis antal och utbredning längs den svenska kusten. Vår Fågelvärld 39: 1-14.

Nilsson, L. 1991. Utbredning, beståndsstorlek samt långtidsflrändringar I beståndens storlek hos övervintrande sjöfåglar I Sverige. Ornis Svecica 1: 11-28.

Nilsson, L. 1997. Changes in numbers and habitat utilization of wintering Whooper Swans Cygnus cygnus in Sweden 1964-1997. Ornis Svecica 7: 133-142.

Nilsson, L. 1999. Internationella sjöfågelräkningarna i Sverige. Pp. 39-46 in Fågelåret 1998. Sveriges Ornitologiska Förening.

Nilsson, L. 2002. Numbers of Mute Swans and Whooper Swans in Sweden, 1967-2000. Pp. 53-60 in Waterbirds 25 (Special publication 1).

Nilsson, L. 2005. Forty years of midwinter counts of waterfowl along the coasts of Scania, south Sweden, 1964 2003. Ornis Svecica 15: 127-148.

Nilsson, L., Andersson, O., Gustafsson, R. \& Svensson, M. 1998. Increase and changes in distribution of breeding Cygnus Cygnus in northern Sweden from 1972-75 to 1997. Wildfowl 49: 6-17.

Owen, M., Atkinson-Willes, G.L. \& Salmon, D. G. 1986. Wildfowl in Great Britain. Second Edition. Cambridge University Press, Cambridge, UK.

Owen, M. \& Cook, W.A. 1977. Variation in body weight and condition of Mallard Anas platyrhynchos and their relationship to environmental changes. J. Zool. London 183: 377-395.

Svensson, S. 1981. Svenska häckfågeltaxeringen 19691980: provytor, punktrutter och vattenfågelområden. Vår Fågelvärld 40:125-132. 


\section{Sammanfattning}

Åren efter andra världskriget hade man i flera länder den uppfattningen att många sjöfågelbestånd hade minskat kraftigt och att man behövde vidta åtgärder för att skydda och sköta bestånden och deras habitat. Man konstaterade tidigt att det behövdes inventeringar för att ge underlag för lämpliga låtgärder. Storbritannien var ett föregångsland i detta avseende och man startade 1947 nationella andfågelinventeringar (Atkinson-Willes 1963), vilka alltjämt pågår nu under namnet Wetland Birds Survey (WEBS).

Regelbundna inventeringar av rastande och övervintrande sjöfåglar startade efter hand i flera andra länder och utfördes ofta på en månatlig basis från tidiga hösten till våren på ett antal lokaler i resp. land. I Sverige startade månatliga andfågelinventeringar i mindre skala 1959/1960 och pågick till och med 1974/1975 (Nilsson 1968, 1976). Eftersom sjöfåglarna flyttar över landsgränser fann man tidigt att internationell samordning var nödvändig, varför the International Waterfowl Research Bureau (numera Wetlands International) startades och bl.a. fick i uppgift att samordna inventeringarna mellan olika länder.

De första årens andfågelinventeringar på nationell nivå gav många intressanta resultat, men man insåg tidigt att det behövdes bättre samordnade insatser på internationell nivå för att nå de uppsatta målen. Detta ledde till att de första internationella midvinterinventeringarna av sjöfåglar $($ IWC $=$ International Waterfowl Census) startades 1967 (Atkinson-Willes 1969). Sverige har varit med i inventeringarna sedan starten (Nilsson 1975, 1991).

Januari valdes som inventeringsmånad eftersom sjöfåglarna då är som mest koncentrerade och därmed lättare att inventera på kontinental nivå.

Från början strävade man efter att få så fullständiga inventeringar som möjligt av viktiga lokaler på en årlig bas. Huvudmålen för projektet var följande:

- Att fastställa utbredningen för de olika arterna på en internationell nivå.

- Att uppskatta storleksordningen för de olika bestånden på en internationell nivå.

- Att skapa ett underlag för att studera långtidstrender i beståndens numerär och förändringar i deras utbredning.

- Att fastställa olika våtmarkslokalers betydelse för de rastande och övervintrande bestånden.

- Att ge råd till myndigheter på olika nivåer i frågor som gäller skötsel av sjöfåglar och våtmarker.
De internationella sjöfågelinventeringarna fick stor framgång redan från början med tusentals medverkande observatörer redan från starten och inventeringarna kom tidigt att täcka huvuddelen av Europa samt angränsande delar av Afrika och Asien (jfr Gilisen et al. 2002, för mer information om den internationella delen av projektet hänvisas till Wetlands Internationals hemsida: www.wetlands.org). Inventeringarna är också kopplade till våtmarkskonventionen och urvalskriterierna för internationellt viktiga sjöfågelområden baseras på dess resultat (Matthews 1993) och inte minst de beståndsskattningar för olika våtmarksfåglar som bl.a. grundas på dessa inventeringar (Delany \& Scott 2006).

Sverige har varit med i de internationella midvinterinventeringarna sedan starten 1967 och projektet fortsätter, numera som en del i Naturvårdsverkets nationella miljöövervakningsprogram (Nilsson 1975, 1991, 2007, se vidare rapporter i appendix).

Under de första årens internationella midvinterinventeringar strävade man efter att täcka så många lokaler som möjligt av dem som bedömdes kunna vara av betydelse för övervintrande sjöfåglar. I många länder såsom Storbritannien, Nederländerna och Tyskland var det möjligt att täcka sjöar, vattendrag och strandnära delar av kusterna ganska fullständigt med observatörskedjor från land. I Sverige med sina skärgårdar och Danmark med stora grunda havsområden var detta inte möjligt, varför inventeringar med flyg introducerades i Danmark 1968 (Joensen 1968) och i Sverige 1971, i Sverige kompletterade med inventeringar från Kustbevakningens båtar.

Efter de första åren med mer eller mindre landsomfattande inventeringar 1971-1973 (Nilsson 1975) med nästan fullständig inventering av de inre farvattnen och inlandet var det klart att det inte är möjligt att åstadkomma en sådan täckning på en årlig basis. Inventeringarna kom därför att inriktas på att ge underlag för beståndsindex genom årliga inventeringar på ett representativt urval av lokaler. Därutöver organiserades mer täckande inventeringar 1987-1989 (ostkustens skärgårdar kunde ej inventeras på grund av dåligt flygväder) samt 2004. De yttre havsområdena ingick inte i de tidiga inventeringarna eftersom det inte var möjligt att täcka de östra delarna av Östersjön före 1991. 1992-1993 organiserades dock en inventering av hela Östersjöns övervintrande sjöfåglar (Durinck et al. 1994).

I föreliggande arbete analyseras resultaten av de första fyrtio årens midvinterinventeringar av sjöfåglar i Sverige. Huvuddelen av arbetet ligger på en 
analys av de förändringar som skett $i$ antal och utbredning för de olika arterna under perioden, bl.a. i relation till de samlade internationella resultaten (Gilissen et al. 2002 samt www.wetlands.org).

\section{Material och metoder}

De internationella midvinterinventeringarna i Sverige liksom i andra länder baseras främst på insatser av frivilliga observatörer som inventerar sjöfåglarna inom en eller flera lokaler på en fastställd dag, helgen närmast den 15 Januari med veckan före och efter som reservperiod. Under de första åren valde observatörerna lokaler, men från 1980-talet standardiserades inventeringarna och ett 60-tal referensområden valdes ut och täcks varje år av inventeringar för indexberäkningarna. Därutöver inventeras ytterligare ett antal lokaler mindre regelbundet.

Under 1971-1973 genomfördes omfattande flyginventeringar för att tillsammans med de landbaserade inventeringarna få en så fullständig täckning som möjligt av landets isfria delar. Under dessa år genomfördes också inventeringar från Kustbevakningens patrullbåtar. Vissa flyginventeringar genomfördes 1974-1977, varefter nya omfattande inventeringar i kombination flyg, landbaserade inventeringar organiserades 1987-1989 samt 2004.

Efter de första årens fria val av inventeringslokaler genomfördes från och med 1971 en sektorsindelning av hela den svenska kusten och större inlandslokaler. Dessa gavs naturliga gränser och en sådan omfattning att de kan täckas med inventeringar under loppet av en dag. Räkningsenheterna efter kusterna grupperades i större naturliga enheter. Hela kusten är indelad i sådana större områden för de landsomfattande inventeringarna, varav ett urval ingår i indexinventeringarna.

I samband med analyserna har de delar av den svenska kusten som var isfria när inventeringarna startade indelats i regioner (Figur 1) efter dessas olika karaktär. Dessa sammanfattas i samband med de mer omfattande inventeringarna i tre större områden: södra Sverige (regionerna A-G samt K och L) samt västkustskärgårdarna och ostkustens skärgårdar. Det område som här betecknas som södra Sverige är det område med öppen kust och endast gles skärgård, som kan täckas med landbaserade inventeringar för alla arter utom havsdykänderna.

Inventeringsmetoderna både vad gäller landbaserade inventeringar och flyginventeringar har diskuterats ingående i de nationella rapporterna (se appendix och hemsidan) och diskuteras inte vidare här. Detsamma gäller metoderna för beräkning av index, där dessa fortfarande beräknats efter principen kedje-index.

Antalet inventerade lokaler har varierat starkt mellan olika år (Tabell 1) och har naturligtvis varit som högst i samband med de landsomfattande inventeringarna. Sedan standardiseringen av lokalindelningen indexberäkningarna har normalt mellan 600 och 700 räknats årligen. Räkningslokalerna är fördelade över södra och mellersta Sverige (Figur 1-3), men en koncentration av dem har skett till ett antal referensområden (Figur 3), vilka sedan 1987-1989 i princip inventerats årligen. Antalet inventerare vid de årliga inventeringarna har varierat mellan 113 och 320 (vartill kommer ett okänt antal medhjälpare till dessa). Totalt har antalet inventerare sedan starten överskridit 2000.

I samband med de landsomfattande inventeringarna 1971-1973 genomfördes flyginventeringar under 96 observationstimmar, vid de ofullständiga inventeringarna 1987-1989 flögs 25 observationstimmar, vilket också var fallet 2004. Under 19711981 genomfördes 100 patrulldagar från kustbevakningens fartyg.

\section{Resultat}

Väderleken och i synnerhet issituationen spelar stor roll för sjöfåglarnas utbredning och numerärförhållanden i ett nordligt land som Sverige. Som en bakgrund redovisas därför medeltemperaturen för ett tiotal stationer i södra och mellersta Sverige för de år inventeringarna genomförts (Figur 5). Rent generellt kan man konstatera att den första halvan av inventeringsperioden var betydligt kallare i snitt än de senare tjugo åren. Under de första tjugo åren inträffade hårda isvintrar vid flera tillfällen: 1970, 1979, 1982, 1985 samt 1987. Däremot förekom senare endast kortare isperioder. Isläget i Östersjön för de 1971 och 2004 (år med landsomfattande inventeringar) samt två av isvintrarna visas i kartor (Figur6).

Det totala beståndet övervintrande andfåglar kunde beräknas för 1971 och 2004 (Tabell 2). 1971 innefattades därutöver bara storskarv och sothöna, medan samtliga arter täcktes av inventeringarna 2004. Södra Sverige (enligt Figur 1) kunde täckas oftare (Tabell 4), medan skärgårdarna på västkusten inventerades även 1987-1989 (Tabell 3) och ostkustskärgårdarna 1972-1973 (Tabell 5).

Totalt beräknades antalet övervintrande sjöfåglar i Sverige till 622.000 i januari 2004 exkl. de havslevande arterna alfågel, svärta och sjöorre, medan motsvarande antal var 166.000 1971. Speciella inventeringar till havs visar dock att alfåglarna 
i de svenska delarna av Östersjön vida överstiger det totala antalet inräknade sjöfåglar av alla arter i de inre farvattnen (Nilsson in prep., Durinck et al. 1994). I de inre farvattnen var viggen den vanligaste arten följt av gräsand och knipa. Artsammansättningen bland de övervintrande sjöfåglarna varierade starkt mellan olika delar av landet, vilket framgår av Figur 7.

Inventeringsresultaten presenteras artsvis $i$ rapporten. För alla viktigare arter visas två utbredningskartor baserade på de landsomfattande inventeringarna 1971-1974 samt 2004. Vidare presenteras de nationella midvinterindex i diagram för aktuella arter. För ett antal arter där underlag för indexberäkning över hela serien saknas exemplifieras beståndsfluktuationerna under den senaste 20-års perioden av diagram som visar de årliga totalsummorna för dessa arter på de årligen inventerade referensområdena. Slutligen exemplifieras den regionala utvecklingen i de övervintrande bestånden för ett antal arter i diagram från ett antal referensområden med fullständiga serier vanligen sedan 1971. Några vanligare arter kommenteras kortfattat nedan:

Gräsanden ökade i antal från 68.000 vid den första landsomfattande inventeringen 1971 till åtminstone 150.000 vid inventeringen 2004. En viss osäkerhet råder om den senare siffran eftersom gräsanden förekommer spridd på många inlandslokaler och därför lätt kan underskattas. Index visar en signifikant ökning över perioden, men kan egentligen brytas ner i två tidsperioder, fluktuationer kring en mer eller mindre stabil nivå fram till 1987 följt av en markant ökning.

Bläsanden är av speciellt intresse eftersom den var en sparsamt förekommande art när inventeringarna startade. Antalet bläsänder ökade markant och arten är nu etablerad som övervintrare i sydligaste Sverige med upp till 8000-9000 inräknade individer.

Viggen har också ökat markant från 54.0001971 till 230.000 2004. Antalet viggar i inlandet (undantag Skåne vissa år) har varit lågt varför kustsiffrorna är representativa för landet. Arten är främst representerad på ostkusten. Liksom för gräsanden kan indexvärdena beskrivas som fluktuerande kring en stabil nivå, för viggen fram till 1991, varefter en mycket markant ökning registrerades.

Brunanden tillhör också de arter som var sparsamma när inventeringarna startade. Antalet är fortfarande inte särskilt högt, 2750 i januari 2004 mot endast 100 1971. Merparten av brunänderna har hela tiden varit koncentrerade till Blekinge.

Knipan är den näst vanligaste arten i de inre kustvattnen efter viggen. Till skillnad från den sistnämnda arten förekommer knipan längs samtliga kustområden och är därutöver spridd $\mathrm{i}$ inlandet. Knipan var också vanlig de senaste åren inom de tidigare istäckta områdena efter norrlandskusten. Vinterbeståndet ökade från ca 18.8001971 till 75.000 2004. Midvinterindex visade markanta ökningar, till skillnad från gräsanden och viggen över hela perioden utan någon initial period med fluktuationer kring en stabil nivå.

Alfågel, svärta och sjöorre tillhör de utpräglat havslevande arterna, vilka inte täcks in av de vanliga midvinterinventeringarna utan kräver speciella insatser. Arterna redovisas ändå för att bilden av sjöfåglarna i de inre täckta områdena av kusterna skall bli fullständig.

Ejdern är främst koncentrerad till västkusten. I januari 2004 skattades beståndet till ca 50.000 att jämföras med 4600 1971. Antalet övervintrande ejdrar i Östersjön uppgår däremot endast till några få hundra. Ejderns midvinterindex visar en signifikant uppgång, men fluktuationerna mellan olika år är markanta.

Småskraken är främst utbredd efter de öppna kusterna av södra Sverige. 2004 beräknades antalet till 6000 att jämföras med 2500 1971. Liksom knipan visade de nationella index en markant uppgång.

Storskraken var liksom övriga arter betydligt vanligare 2004 än 1971, 25.000 mot 8600. Index visar dock ingen klar trend utan endast fluktuationer. Storskraken uppträder i betydande flockar, vilket gör att det lätt kan uppstå variationer i räkningarna under en serie. Utbredningen är främst begränsad till ostkusten, men betydande antal kan förekomma i inlandet under milda perioder. En sådan utspridning kan på verka årsindex i betydande utsträckning.

Salskraken var också en sparsam art när inventeringarna startade med ca 400 inräknade i januari 1971 mot 3800 2004. Till en början var arten markant koncentrerad till Skåne och Blekinge, men flockar har också börjat visa sig längre norrut på ostkusten.

Knölsvanens index visar måttliga fluktuationer under de första åren, varefter en markant ökning ägde rum. Vid de landsomfattande inventeringarna ökade antalet från 7500 till 35.000. Arten är allmän både på ostkusten och västkusten.

Sångsvanens index visar också en betydande ökning, men samtidigt har arten ändrat vanor och betar $\mathrm{i}$ allt högre grad på land. Den kommer sålunda inte med i de vanliga midvinterinventeringarna som koncentreras till vattenområden. Speci- 
ella sångsvan-inventeringar har därför organiserats på internationell nivå 1995, 2000 och 2005. Vid 1970-talets början uppgick vinterbeståndet till 2100 att jämföras med 9500 i januari 2005.

Sothönan är den art där index visat mest variation. Från låga värden ökade index markant under de milda åren på 1970-talet för att sedan "krascha" efter den hårda isvintern 1979. Under 1980-talets vintrar med kalla förhållanden var antalet lågt för att sedan öka igen under den senare delen av inventeringsperioden. 18000 beräknades vid inventeringen 2004 att jämföra med 40001971

Skäggdoppingen var sparsamt förekommande när inventeringarna startade och sågs endast $\mathrm{i}$ spridda individ. Antalet skäggdoppingar ökade markant under senare år och i januari 2004 beräknades antalet övervintrare till över 5000 .

Storskarven har också ökat markant som övervintrare under perioden, 1971 sågs 1100 att jämföras med mer än 12000 2004. Då merparten av skarvarna vistas i ytterskärgårdarna som är svårinventerade har årsindex inte kunnat beräknas.

Ytterligare ett antal arter har setts i mindre antal. För dessa hänvisas till de diagram som visas i huvudtexten samt de inledande tabellerna från totalinventeringarna.

\section{Diskussion}

Beläget i norra Europa med istäckta sjöar de flesta år erbjuder inte Sveriges inland speciellt många lokaler för de övervintrande sjöfåglarna. Däremot finns betydande områden med grunt vatten och goda övervintringsmöjligheter längs kusterna. De internationella sjöfågelinventeringarna ger ett bra underlag för att bedöma de olika sjöfågelarternas uppträdande i landet i relation till de europeiska vinterbestånden. I Tabell 6 sammanfattas beståndsstorleken för de viktigaste arterna i nordvästra Europa i jämförelse med inventeringsresultaten från de svenska inventeringarna. För viggen konstaterades Sverige hysa $19 \%$ av totalbeståndet och för sångsvanen $14-16 \%$, men landet är viktigt också för knipa, ejder, storskrake och småskrake med andelar på mellan $5 \%$ och $10 \%$. Sveriges betydelse torde vara ändå högre för den havslevande alfågeln, där bortemot $25 \%$ eller fler av de övervintrande alfåglarna i Europa finns i svenska östersjövatten.

Jämförelsen mellan de landsomfattande inventeringarna 1971 och 2004 visar markanta ökningar i antalet övervintrande sjöfåglar. Nio av tio indexarter visade signifikant ökande trender, endast storskraken uppvisar fluktuerande index, men även för den arten visade de landsomfattande invente- ringarna en ökning. Två arter har etablerat sig som övervintrare under perioden: bläsand och skäggdopping. Dessutom var salskraken och storskarven sparsamma i början och har ökat markant.

Analyserna av de regionala räkningarna visar att utvecklingen har varierat en hel del på lokal nivå och också mellan olika delar av landet. Vissa arter har till och med minskat på de sydligare lokalerna för att bli vanligare längre norrut.

För ett antal arter är det möjligt att jämföra resultaten från andfågelinventeringarna med en oberoende dataserie. Punktinventeringarna inom ramen för Svens Fågeltaxering (Lindström \& Svensson 2007) ger underlag för att beräkna trender för ett antal arter som även täcks av sjöfågelinventeringarna. Punktinventeringarna vintertid visade signifikant ökande trender för häger, storskarv, gräsand, vigg, knipa, storskrake, salskrake, knölsvan och sångsvan, medan endast svaga ökande trender noterades för brunand och småskrake. Man fann däremot inga trender för alfågel, ejder och sothöna. Överensstämmelsen mellan de båda inventeringarna var således mycket god.

Analysen av indexserier baserade på inventeringar $i$ enskilda länder som Sverige ger emellertid inget underlag för att bedöma huruvida ökningen i antalet övervintrare beror på en reell ökning i de berörda populationernas storlek eller ändrade utbredningsförhållanden eller bådadera. För en del arter finns internationella resultat tillgängliga och kan belysa denna fråga (Delany et al 1999, www. wetlands.org).

För gräsanden visar de internationella index en varierande bild, med ökningar i index för Östersjöregionen, medan en viss nedgång noteras för nordvästra Europa i övrigt. De internationella inventeringarna ger således ingen klar ledning, men man torde kunna räkna med att en betydande del av uppgången i de svenska vinter index förklaras av förskjutningar norrut i samband med de mildare vintrarna.

För vigg, knipa och småskrake noterades ökningar i de internationella index för båda de nordliga regionerna, varför ökningarna i de svenska och internationella vinter index torde motsvaras av reella beståndsökningar, även om en betydande del av ökningen av de svenska vinterindex motsvaras av ändrad vinter-utbredning. Brunandens ökning torde däremot kanske mer bero på ändrade utbredningsförhållanden som respons på milda vintrar.

När det gäller ejdern visar materialet från midvinterinventeringen en mycket markant ökning i vinterbeståndet från 1971 till 2004. Bilden är emellertid något mer komplicerad och särskilt flyg- 
inventeringar från de danska farvattnen visar att ejdrarna minskat markant under senare år (Desholm et al. 2002). Den sena nedgången i ejderbeståndet syns inte i de svenska vinterindexen.

Båda svanarterna visade ökningar både $\mathrm{i}$ de svenska index och internationellt. För sångsvanen motsvaras ökningen av en markant ökning i det häckande svenska beståndet (Nilsson et al. 1998, Arvidsson 1997).

Sommarpunkttaxeringarna inom svensk fågeltaxering visade också signifikanta ökande trender för storskarv, häger, gräsand, ejder, knölsvan och sångsvan. Arter som också visat ökningar enligt vinterinventeringarna, se dock ovan för ejdern (jfr Desholm et al. 2002).

Jämförelserna mellan de svenska index och de internationella index (liksom inventeringarna inom Svensk Häckfågeltaxering) visar klart att en del av beståndsförändringarna noterade i vinterinventeringarna motsvarar genuina förändringar i beståndens storlek. Därutöver torde en betydande del av ökningen för vissa arter kunna relateras till ändrade förhållanden i relation till mildare vintrar.

Förutom de noterade förändringarna på landsnivå som påvisats ovan har betydande förändringar i den lokala utbredningen kunnat dokumenteras för flera arter både vad gäller beståndsökningens storlek i olika regioner (Tabell 3-5) och flera arters uppträdande i övrigt belyst av de presenterade inventeringarna i referensområdena. Samtidigt som flera arter ändrat sin utbredning under vintern har en art mycket påtagligt ändrat sina vanor under perioden, sångsvanen, som övergått till att söka föda på fälten $i$ stor utsträckning och inte som tidigare endast i vattenområdena (Laubek et al. 1999, Nilsson 1997).

De milda vintrarnas betydelse för sjöfågelbestånden i Sverige framgår markant av de ovan diskuterade ökningarna i vinterindex, vilka till en betydande del kunnat förklaras av ändringar i utbredning relaterat till ändrade vinterförhållanden. Man skulle därför kunna förvänta sig det motsatta i samband med kalla vintrar, dvs. en nedgång i bestånden. I flera fall har låga nationella index eller låga räkningsresultat från enstaka områden kunnat relateras till kalla vintrar, men i de flesta fall har arten återgått till tidigare antal senare år. För sothönan kunde emellertid konstateras att beståndet kraschade $\mathrm{i}$ samband med den hårda vintern 1978/79, som medförde en drastisk minskning i index som låg kvar på en låg nivå under många följande år. Denna beståndsnedgång kunde spåras både $\mathrm{i}$ vinterindex från andra länder (Delany et al. 1999) samt i de svenska häckfågeltaxeringarna (Svensson 1981). 
Appendix 1. Regional totals for the coast. Grey: no or incomplete data. See Figure 1 for regions. Regionala summor för kusten. Grått: inga eller ofullständiga data. Se Figur 1 för regioner

Mallard Anas platyrhynchos

\begin{tabular}{|c|c|c|c|c|c|c|c|c|c|}
\hline & Region & 1971 & 1972 & 1973 & 1987 & 1988 & 1989 & 1993 & 2004 \\
\hline V & Bohuslän & 1083 & & & 3023 & 4315 & 2333 & & 7055 \\
\hline A & N.Halland & 1050 & 1130 & & 455 & 3668 & 770 & & 1134 \\
\hline B & Varberg-Kullen & 4800 & 6250 & 5610 & 5162 & 13000 & 13540 & & 9972 \\
\hline $\mathrm{C}$ & Öresund & 6570 & 8580 & 9660 & 5620 & 6650 & 7170 & 9771 & 9642 \\
\hline D & Falsterbo-Hanö & 2490 & 1400 & 3660 & 1393 & 4157 & 4155 & 7535 & 9865 \\
\hline $\mathrm{E}$ & Blekinge skärg. & 870 & 3800 & 2170 & 1550 & 1610 & 3786 & 3844 & 5019 \\
\hline $\mathrm{F}$ & S.Kalmarsund & 1120 & 3840 & 2200 & 1370 & 1368 & 2646 & 4446 & 5897 \\
\hline G & N.Kalmarsund & 160 & 1110 & 740 & 20 & 160 & 780 & 1909 & 2809 \\
\hline $\mathrm{H}$ & H skärgård & 570 & 1630 & 930 & & & & & 701 \\
\hline K & Öland & 1270 & 3220 & 3350 & 1212 & 1757 & 3560 & 5377 & 5058 \\
\hline $\mathrm{L}$ & Gotland & 5030 & 5430 & 5900 & 2525 & 4295 & 8500 & 12671 & 12214 \\
\hline M & E skärgård & 160 & 270 & 1200 & & & & & 477 \\
\hline $\mathrm{N}$ & D skärgård & 130 & 1260 & 1060 & & & & & 857 \\
\hline $\mathrm{O}$ & $B$ skärgård & 4100 & 4100 & 3430 & & & & & 7055 \\
\hline & Total & 29403 & & & & & & & 77755 \\
\hline
\end{tabular}

Teal Anas crecca

\begin{tabular}{|c|c|c|c|c|c|c|c|c|c|}
\hline & Region & 1971 & 1972 & 1973 & 1987 & 1988 & 1989 & 1993 & 2004 \\
\hline V & Bohuslän & 0 & & & 0 & 0 & 0 & & 11 \\
\hline A & N.Halland & 0 & 0 & & 0 & 0 & 0 & & 4 \\
\hline B & Varberg-Kullen & 7 & 0 & 24 & 11 & 31 & 24 & & 48 \\
\hline $\mathrm{C}$ & Öresund & 0 & 2 & 2 & 0 & 3 & 0 & 8 & 81 \\
\hline $\mathrm{D}$ & Falsterbo-Hanö & 0 & 0 & 0 & 0 & 0 & 10 & 7 & 56 \\
\hline $\mathrm{E}$ & Blekinge skärg. & 0 & 0 & 0 & 0 & 0 & 0 & 4 & 59 \\
\hline $\mathrm{F}$ & S.Kalmarsund & 0 & 0 & 0 & 0 & 0 & 0 & 0 & 0 \\
\hline G & N.Kalmarsund & 0 & 0 & 0 & 0 & 0 & 0 & 0 & 0 \\
\hline $\mathrm{H}$ & H skärgård & 0 & 0 & 0 & & & & & 0 \\
\hline K & Öland & 0 & 0 & 41 & 0 & 4 & 1 & 0 & 14 \\
\hline $\mathrm{L}$ & Gotland & 0 & 0 & 1 & 0 & 0 & 1 & 19 & 39 \\
\hline M & E skärgård & 0 & 0 & 0 & & & & & 0 \\
\hline $\mathrm{N}$ & D skärgård & 0 & 0 & 0 & & & & & 0 \\
\hline $\mathrm{O}$ & B skärgård & 0 & 0 & 0 & & & & & 3 \\
\hline & Total & 7 & & & & & & & 315 \\
\hline
\end{tabular}

Wigeon Anas penelope

\begin{tabular}{|c|c|c|c|c|c|c|c|c|c|}
\hline & Region & 1971 & 1972 & 1973 & 1987 & 1988 & 1989 & 1993 & 2004 \\
\hline V & Bohuslän & 0 & & & 0 & 2 & 0 & & 1 \\
\hline A & N.Halland & 0 & 0 & & 0 & 1 & 0 & & 0 \\
\hline B & Varberg-Kullen & 0 & 1 & 0 & 0 & 4 & 5 & & 237 \\
\hline $\mathrm{C}$ & Öresund & 3 & 12 & 73 & 0 & 242 & 439 & 1924 & 5175 \\
\hline $\mathrm{D}$ & Falsterbo-Hanö & 0 & 0 & 0 & 0 & 0 & 2 & 0 & 119 \\
\hline $\mathrm{E}$ & Blekinge skärg. & 0 & 0 & 0 & 0 & 0 & 2 & 1 & 5 \\
\hline $\mathrm{F}$ & S.Kalmarsund & 0 & 0 & 0 & 0 & 0 & 0 & 1 & 0 \\
\hline G & N.Kalmarsund & 0 & 0 & 0 & 0 & 0 & 0 & 0 & 0 \\
\hline $\mathrm{H}$ & H skärgård & 0 & 0 & 0 & & & & & 0 \\
\hline K & Öland & 0 & 0 & 1 & 0 & 1 & 0 & 30 & 16 \\
\hline $\mathrm{L}$ & Gotland & 0 & 0 & 0 & 0 & 0 & 2 & 2 & 8 \\
\hline M & E skärgård & 0 & 0 & 0 & & & & & 0 \\
\hline $\mathrm{N}$ & D skärgård & 0 & 0 & 0 & & & & & 0 \\
\hline $\mathrm{O}$ & $\mathrm{B}$ skärgård & 0 & 0 & 0 & & & & & 1 \\
\hline & Total & 3 & & & & & & & 5562 \\
\hline
\end{tabular}


Appendix 1, continued.

Pintail Anas acuta

\begin{tabular}{|c|c|c|c|c|c|c|c|c|c|}
\hline & Region & 1971 & 1972 & 1973 & 1987 & 1988 & 1989 & 1993 & 2004 \\
\hline V & Bohuslän & 0 & & & 0 & 0 & 0 & & 0 \\
\hline A & N.Halland & 0 & 0 & & 0 & 0 & 0 & & 0 \\
\hline B & Varberg-Kullen & 3 & 0 & 1 & 1 & 3 & 0 & & 5 \\
\hline $\mathrm{C}$ & Öresund & 0 & 2 & 2 & 1 & 0 & 8 & 20 & 7 \\
\hline $\mathrm{D}$ & Falsterbo-Hanö & 1 & 0 & 0 & 0 & 0 & 1 & 0 & 0 \\
\hline E & Blekinge skärg. & 0 & 0 & 0 & 0 & 0 & 0 & 0 & 0 \\
\hline $\mathrm{F}$ & S.Kalmarsund & 0 & 0 & 0 & 0 & 0 & 0 & 0 & 0 \\
\hline G & N.Kalmarsund & 0 & 0 & 0 & 0 & 0 & 0 & 0 & 0 \\
\hline $\mathrm{H}$ & H skärgård & 0 & 0 & 0 & & & & & 0 \\
\hline K & Öland & 0 & 0 & 0 & 0 & 0 & 0 & 0 & 0 \\
\hline $\mathrm{L}$ & Gotland & 0 & 1 & 0 & 0 & 0 & 0 & 3 & 2 \\
\hline M & E skärgård & 0 & 0 & 0 & & & & & 0 \\
\hline $\mathrm{N}$ & D skärgård & 0 & 0 & 0 & & & & & 0 \\
\hline $\mathrm{O}$ & B skärgård & 0 & 0 & 0 & & & & & 0 \\
\hline & Total & 4 & & & & & & & 14 \\
\hline
\end{tabular}

Scaup Aythya marila

\begin{tabular}{|c|c|c|c|c|c|c|c|c|c|}
\hline & Region & 1971 & 1972 & 1973 & 1987 & 1988 & 1989 & 1993 & 2004 \\
\hline V & Bohuslän & 0 & & & 0 & 25 & & & 10 \\
\hline A & N.Halland & 0 & 0 & & 2 & 0 & 70 & & 0 \\
\hline B & Varberg-Kullen & 4 & 1 & 111 & 0 & 13 & 384 & & 22 \\
\hline $\mathrm{C}$ & Öresund & 68 & 43 & 110 & 16 & 34 & 36 & 491 & 296 \\
\hline $\mathrm{D}$ & Falsterbo-Hanö & 210 & 1 & 12 & 66 & 229 & 54 & 2 & 126 \\
\hline $\mathrm{E}$ & Blekinge skärg. & 25 & 0 & 0 & 23 & 145 & 182 & 156 & 326 \\
\hline $\mathrm{F}$ & S.Kalmarsund & 0 & 0 & 23 & 0 & 150 & 30 & 39 & 338 \\
\hline G & N.Kalmarsund & 3 & 0 & 0 & 1 & 15 & 21 & 20 & 14 \\
\hline $\mathrm{H}$ & H skärgård & 0 & 3 & 0 & & & & & 0 \\
\hline K & Öland & 0 & 0 & 8 & 17 & 51 & 141 & 72 & 565 \\
\hline $\mathrm{L}$ & Gotland & 790 & 76 & 100 & 93 & 2761 & 1633 & 6970 & 1167 \\
\hline M & E skärgård & 0 & 0 & 0 & & & & & 0 \\
\hline $\mathrm{N}$ & D skärgård & 0 & 0 & 0 & & & & & 112 \\
\hline $\mathrm{O}$ & B skärgård & 0 & 0 & 0 & & & & & 177 \\
\hline & Total & 1100 & & & & & & & 3153 \\
\hline
\end{tabular}

\section{Tufted Duck Aythya fuligula}

\begin{tabular}{|c|c|c|c|c|c|c|c|c|c|}
\hline & Region & 1971 & 1972 & 1973 & 1987 & 1988 & 1989 & 1993 & 2004 \\
\hline V & Bohuslän & 1020 & & & 4 & 82 & & & 328 \\
\hline A & N.Halland & 2 & 15 & 0 & 4 & 129 & 20 & 0 & 285 \\
\hline B & Varberg-Kullen & 880 & 390 & 400 & 99 & 162 & 569 & 0 & 169 \\
\hline $\mathrm{C}$ & Öresund & 7130 & 8240 & 12910 & 10280 & 3190 & 2620 & 4408 & 10231 \\
\hline $\mathrm{D}$ & Falsterbo-Hanö & 4240 & 6600 & 10920 & 5254 & 1453 & 1151 & 3152 & 7663 \\
\hline $\mathrm{E}$ & Blekinge skärg. & 8380 & 11770 & 21580 & 11147 & 18537 & 28690 & 20661 & 32435 \\
\hline $\mathrm{F}$ & S.Kalmarsund & 4640 & 6580 & 7020 & 1370 & 7540 & 2925 & 9269 & 25753 \\
\hline G & N.Kalmarsund & 570 & 1000 & 890 & 2435 & 4850 & 6820 & 16578 & 38147 \\
\hline $\mathrm{H}$ & H skärgård & 250 & 520 & 4950 & & & & & 4644 \\
\hline K & Öland & 1800 & 3600 & 2270 & 5440 & 1920 & 1710 & 2595 & 5906 \\
\hline $\mathrm{L}$ & Gotland & 8140 & 2770 & 10520 & 15060 & 10770 & 17230 & 18846 & 25410 \\
\hline M & E skärgård & 25 & 22 & 85 & & & & & 6170 \\
\hline $\mathrm{N}$ & D skärgård & 120 & 120 & 1650 & & & & & 17573 \\
\hline $\mathrm{O}$ & B skärgård & 15000 & 16000 & 10600 & & & & & 50235 \\
\hline & Total & 52197 & & & & & & & 224949 \\
\hline
\end{tabular}


Appendix 1, continued.

Pochard Aythya ferina

\begin{tabular}{|c|c|c|c|c|c|c|c|c|c|}
\hline & Region & 1971 & 1972 & 1973 & 1987 & 1988 & 1989 & 1993 & 2004 \\
\hline V & Bohuslän & 40 & & & 1 & 3 & 0 & & 3 \\
\hline A & N.Halland & 0 & 0 & & 1 & 0 & 10 & & 0 \\
\hline B & Varberg-Kullen & 3 & 0 & 13 & 4 & 5 & 4 & & 0 \\
\hline $\mathrm{C}$ & Öresund & 33 & 50 & 59 & 24 & 56 & 50 & 67 & 257 \\
\hline D & Falsterbo-Hanö & 7 & 150 & 220 & 49 & 42 & 4 & 8 & 307 \\
\hline $\mathrm{E}$ & Blekinge skärg. & 1 & 0 & 0 & 56 & 556 & 1001 & 1030 & 1359 \\
\hline $\mathrm{F}$ & S.Kalmarsund & 7 & 1 & 53 & 0 & 51 & 11 & 46 & 112 \\
\hline G & N.Kalmarsund & 1 & 0 & 0 & 38 & 2 & 9 & 20 & 51 \\
\hline $\mathrm{H}$ & H skärgård & 0 & 50 & 39 & & & & & 0 \\
\hline K & Öland & 0 & 1 & 0 & 1 & 100 & 62 & 70 & 329 \\
\hline $\mathrm{L}$ & Gotland & 0 & 0 & 6 & 14 & 25 & 47 & 116 & 85 \\
\hline M & E skärgård & 0 & 0 & 0 & & & & & 0 \\
\hline $\mathrm{N}$ & D skärgård & 0 & 2 & 0 & & & & & 0 \\
\hline $\mathrm{O}$ & B skärgård & 0 & 0 & 2 & & & & & 157 \\
\hline & Total & 92 & & & & & & & 2660 \\
\hline
\end{tabular}

Goldeneye Bucephala clangula

\begin{tabular}{|c|c|c|c|c|c|c|c|c|c|}
\hline & Region & 1971 & 1972 & 1973 & 1987 & 1988 & 1989 & 1993 & 2004 \\
\hline $\mathrm{V}$ & Bohuslän & 996 & & & 1242 & 2967 & 1803 & & 13161 \\
\hline A & N.Halland & 630 & 840 & & 428 & 1011 & 154 & & 1742 \\
\hline B & Varberg-Kullen & 1320 & 1020 & 1030 & 960 & 1210 & 1170 & & 668 \\
\hline $\mathrm{C}$ & Öresund & 2310 & 2830 & 3260 & 3060 & 1980 & 2170 & 2721 & 3174 \\
\hline D & Falsterbo-Hanö & 5040 & 3380 & 7230 & 9360 & 3467 & 3700 & 4324 & 4731 \\
\hline $\mathrm{E}$ & Blekinge skärg. & 1080 & 2040 & 3180 & 674 & 1372 & 1261 & 1093 & 2410 \\
\hline $\mathrm{F}$ & S.Kalmarsund & 690 & 1380 & 2320 & 363 & 1164 & 494 & 2483 & 1555 \\
\hline G & N.Kalmarsund & 290 & 600 & 290 & 275 & 865 & 1230 & 1909 & 1402 \\
\hline $\mathrm{H}$ & H skärgård & 200 & 280 & 270 & & & & & 779 \\
\hline $\mathrm{K}$ & Öland & 1910 & 3400 & 4090 & 3608 & 4193 & 4307 & 6424 & 3722 \\
\hline $\mathrm{L}$ & Gotland & 2330 & 2710 & 2750 & 5252 & 7176 & 5136 & 4817 & 12982 \\
\hline $\mathrm{M}$ & E skärgård & 190 & 150 & 330 & & & & & 1754 \\
\hline $\mathrm{N}$ & D skärgård & 120 & 60 & 340 & & & & & 2498 \\
\hline $\mathrm{O}$ & $\mathrm{B}$ skärgård & 500 & 1650 & 1440 & & & & & 21294 \\
\hline & Total & 17606 & & & & & & & 71872 \\
\hline
\end{tabular}

\section{Long-tailed Duck Clangula hyemalis}

\begin{tabular}{|c|c|c|c|c|c|c|c|c|c|}
\hline & Region & 1971 & 1972 & 1973 & 1987 & 1988 & 1989 & 1993 & 2004 \\
\hline V & Bohuslän & 87 & & & 0 & 0 & 81 & & 11 \\
\hline A & N.Halland I & 0 & 1 & & 0 & 0 & 0 & & 1 \\
\hline B & Varberg-Kullen & 11 & 16 & 29 & 5 & 22 & 110 & & 21 \\
\hline $\mathrm{C}$ & Öresund & 1 & 3 & 43 & 1 & 7 & 2 & 5 & 28 \\
\hline D & Falsterbo-Hanö I & 4590 & 3240 & 4400 & 1700 & 660 & 244 & 1246 & 740 \\
\hline $\mathrm{E}$ & Blekinge skärg. & 1030 & 1640 & 780 & 221 & 76 & 32 & 281 & 46 \\
\hline $\mathrm{F}$ & S.Kalmarsund & & & & \multirow{8}{*}{8821} & \multirow{8}{*}{7310} & \multirow{8}{*}{7380} & \multirow{8}{*}{7349} & \\
\hline G & N.Kalmarsund I & & & & & & & & \\
\hline $\mathrm{H}$ & H.skärgård & 4700 & 8220 & 9800 & & & & & \\
\hline $\mathrm{K}$ & Öland tot & & 16100 & 22300 & & & & & 24788 \\
\hline $\mathrm{L}$ & Gotland I & 5680 & 8510 & 7640 & & & & & 5064 \\
\hline M & E skärgård & 900 & 900 & 200 & & & & & 168 \\
\hline $\mathrm{N}$ & D skärgård & 2500 & 1000 & 3500 & & & & & 498 \\
\hline $\mathrm{O}$ & B skärgård & 24000 & 22000 & 15300 & & & & & 5349 \\
\hline
\end{tabular}


Appendix 1, continued.

Velvet Scoter Melanitta fusca

\begin{tabular}{|c|c|c|c|c|c|c|c|c|c|}
\hline & Region & 1971 & 1972 & 1973 & 1987 & 1988 & 1989 & 1993 & 2004 \\
\hline $\mathrm{V}$ & Bohuslän & 10 & & & 0 & 131 & 136 & & 13 \\
\hline A & N.Halland I & 0 & 0 & & 5 & 0 & 0 & & \\
\hline B & Varberg-Kullen & 55 & 1850 & 2050 & 8 & 820 & 658 & & 874 \\
\hline $\mathrm{C}$ & Öresund & 1 & 0 & 0 & 0 & 0 & 0 & 0 & 1 \\
\hline D & Falsterbo-Hanö I & & & & & & & & \\
\hline $\mathrm{E}$ & Blekinge skärg. & 87 & 24 & 0 & 0 & 0 & 0 & 0 & 1 \\
\hline $\begin{array}{l}F \\
G\end{array}$ & $\begin{array}{l}\text { S.Kalmarsund } \\
\text { K.Kalmarsund I }\end{array}$ & & & & & & & & \\
\hline $\mathrm{H}$ & H.skärgård & 0 & 0 & 2 & & & & & \\
\hline K & Öland & & & & & & & & \\
\hline L & Gotland I & & & & & & & & \\
\hline M & E skärgård & 0 & 2 & 3 & & & & & \\
\hline $\mathrm{N}$ & D skärgård & 0 & 0 & 3 & & & & & \\
\hline $\mathrm{O}$ & B skärgård & 4 & 0 & 63 & & & & & 7 \\
\hline & Total & 676 & & & & & & & 1175 \\
\hline
\end{tabular}

Common Scoter Melanitta nigra

\begin{tabular}{|c|c|c|c|c|c|c|c|c|c|}
\hline & Region & 1971 & 1972 & 1973 & 1987 & 1988 & 1989 & 1993 & 2004 \\
\hline V & Bohuslän & 14 & & & 11 & 56 & 128 & & 76 \\
\hline A & N.Halland & 0 & 0 & & 0 & 1 & 0 & & 0 \\
\hline B & Varberg-Kullen & 200 & 280 & 180 & 7 & 191 & 506 & & 2408 \\
\hline $\mathrm{C}$ & Öresund & 6 & 0 & 0 & 1 & 0 & 0 & 0 & 0 \\
\hline $\mathrm{D}$ & Falsterbo-Hanö I & & & & & & & & \\
\hline $\mathrm{E}$ & Blekinge skärg. & 2 & 21 & 0 & 0 & 0 & 0 & 0 & 1 \\
\hline $\begin{array}{l}F \\
G\end{array}$ & $\begin{array}{l}\text { S.Kalmarsund } \\
\text { N.Kalmarsund I }\end{array}$ & & & & & & & & \\
\hline $\mathrm{H}$ & H.skärgård & 0 & 2 & 0 & & & & & \\
\hline $\mathrm{K}$ & Öland & & & & & & & & \\
\hline $\mathrm{L}$ & Gotland I & & & & & & & & \\
\hline $\mathrm{M}$ & E skärgård & 1 & 9 & 0 & & & & & 0 \\
\hline $\mathrm{N}$ & D skärgård & 0 & 1 & 0 & & & & & 30 \\
\hline $\mathrm{O}$ & B skärgård & 1 & 0 & 41 & & & & & 35 \\
\hline & Total & 642 & & & & & & & 4457 \\
\hline
\end{tabular}

Eider Somateria mollissima

\begin{tabular}{|c|c|c|c|c|c|c|c|c|c|}
\hline & Region & 1971 & 1972 & 1973 & 1987 & 1988 & 1989 & 1993 & 2004 \\
\hline V & Bohuslän & 2881 & & & 1918 & 4702 & 5549 & & 36582 \\
\hline A & N.Halland & 120 & 230 & & 142 & 107 & 23 & & 1488 \\
\hline B & Varberg-Kullen & 670 & 950 & 930 & 207 & 1732 & 1010 & & 9300 \\
\hline $\mathrm{C}$ & Öresund & 120 & 250 & 310 & 169 & 61 & 53 & 298 & 1133 \\
\hline $\mathrm{D}$ & Falsterbo-Hanö & 290 & 480 & 650 & 830 & 170 & 174 & 233 & 52 \\
\hline $\mathrm{E}$ & Blekinge skärg. & 55 & 230 & 140 & 0 & 0 & 60 & 11 & 9 \\
\hline $\mathrm{F}$ & S.Kalmarsund & 22 & 10 & 71 & 16 & 13 & 71 & 47 & 41 \\
\hline G & N.Kalmarsund & 25 & 27 & 12 & 1 & 0 & 11 & 16 & 15 \\
\hline $\mathrm{H}$ & H skärgård & 8 & 90 & 120 & & & & & 44 \\
\hline K & Öland & 25 & 190 & 300 & 96 & 31 & 150 & 84 & 16 \\
\hline $\mathrm{L}$ & Gotland & 100 & 210 & 250 & 69 & 115 & 465 & 206 & 159 \\
\hline M & E skärgård & 1 & 90 & 15 & & & & & 0 \\
\hline $\mathrm{N}$ & D skärgård & 40 & 21 & 51 & & & & & 0 \\
\hline $\mathrm{O}$ & B skärgård & 180 & 280 & 150 & & & & & 116 \\
\hline & Total & 4537 & & & & & & & 48955 \\
\hline
\end{tabular}


Appendix 1, continued.

Red-breasted Merganser Mergus serrator

\begin{tabular}{|c|c|c|c|c|c|c|c|c|c|}
\hline & Region & 1971 & 1972 & 1973 & 1987 & 1988 & 1989 & 1993 & 2004 \\
\hline V & Bohuslän & 214 & & & 427 & 1006 & 1076 & & 1313 \\
\hline A & N.Halland & 250 & 320 & & 281 & 577 & 64 & & 51 \\
\hline B & Varberg-Kullen & 210 & 590 & 270 & 601 & 688 & 198 & & 344 \\
\hline $\mathrm{C}$ & Öresund & 90 & 95 & 380 & 594 & 131 & 103 & 108 & 281 \\
\hline $\mathrm{D}$ & Falsterbo-Hanö & 260 & 210 & 710 & 766 & 258 & 299 & 102 & 844 \\
\hline E & Blekinge skärg. & 55 & 230 & 140 & 135 & 18 & 33 & 29 & 261 \\
\hline $\mathrm{F}$ & S.Kalmarsund & 230 & & 19 & 152 & 90 & 97 & 37 & 201 \\
\hline G & N.Kalmarsund & 90 & 17 & 45 & 3 & 226 & 197 & 52 & 73 \\
\hline $\mathrm{H}$ & H skärgård & 90 & 0 & 40 & & & & & 50 \\
\hline K & Öland & 300 & 260 & 830 & 670 & 737 & 428 & 21 & 464 \\
\hline $\mathrm{L}$ & Gotland & 630 & 870 & 1270 & 912 & 1451 & 1436 & 838 & 1445 \\
\hline M & E skärgård & 10 & 0 & 0 & & & & & 0 \\
\hline $\mathrm{N}$ & D skärgård & 5 & 100 & 5 & & & & & 0 \\
\hline \multirow[t]{2}{*}{$\mathrm{O}$} & B skärgård & 5 & 0 & 5 & & & & & 7 \\
\hline & Total & 2439 & & & & & & & 5334 \\
\hline
\end{tabular}

Goosander Mergus merganser

\begin{tabular}{|c|c|c|c|c|c|c|c|c|c|}
\hline & Region & 1971 & 1972 & 1973 & 1987 & 1988 & 1989 & 1993 & 2004 \\
\hline V & Bohuslän & 114 & & & 790 & 356 & 66 & & 1020 \\
\hline A & N.Halland & 65 & 15 & & 149 & 542 & 6 & & 20 \\
\hline B & Varberg-Kullen & 150 & 150 & 140 & 1170 & 34 & 43 & & 60 \\
\hline $\mathrm{C}$ & Öresund & 790 & 150 & 350 & 625 & 80 & 64 & 101 & 198 \\
\hline D & Falsterbo-Hanö & 1020 & 620 & 1160 & 2111 & 35 & 66 & 252 & 382 \\
\hline $\mathrm{E}$ & Blekinge skärg. & 490 & 790 & 1520 & 566 & 244 & 511 & 1069 & 983 \\
\hline $\mathrm{F}$ & S.Kalmarsund & 510 & 56 & 530 & 1147 & 272 & 381 & 1722 & 899 \\
\hline G & N.Kalmarsund & 360 & 390 & 180 & 325 & 221 & 304 & 3158 & 2193 \\
\hline $\mathrm{H}$ & H skärgård & 530 & 260 & 510 & & & & & 1977 \\
\hline $\mathrm{K}$ & Öland & 130 & 120 & 140 & 950 & 384 & 362 & 424 & 954 \\
\hline $\mathrm{L}$ & Gotland & 620 & 550 & 470 & 1324 & 1183 & 1750 & 7491 & 2870 \\
\hline $\mathrm{M}$ & E skärgård & 160 & 610 & 1150 & & & & & 1104 \\
\hline $\mathrm{N}$ & D skärgård & 900 & 500 & 570 & & & & & 1114 \\
\hline $\mathrm{O}$ & B skärgård & 2000 & 3000 & 2340 & & & & & 4230 \\
\hline & Total & 7839 & & & & & & & 18004 \\
\hline
\end{tabular}

\section{Smew Mergus albellus}

\begin{tabular}{|c|c|c|c|c|c|c|c|c|c|}
\hline & Region & 1971 & 1972 & 1973 & 1987 & 1988 & 1989 & 1993 & 2004 \\
\hline V & Bohuslän & 0 & & & 10 & 9 & 0 & & 52 \\
\hline A & N.Halland & 0 & 1 & & 8 & 0 & 1 & & 24 \\
\hline B & Varberg-Kullen & 0 & 7 & 0 & 1 & 3 & 2 & & 1 \\
\hline $\mathrm{C}$ & Öresund & 92 & 78 & 113 & 17 & 1 & 10 & 38 & 33 \\
\hline $\mathrm{D}$ & Falsterbo-Hanö & 176 & 44 & 225 & 180 & 3 & 2 & 17 & 236 \\
\hline E & Blekinge skärg. & 64 & 5 & 38 & 57 & 16 & 155 & 146 & 1017 \\
\hline $\mathrm{F}$ & S.Kalmarsund & 5 & 12 & 0 & 6 & 2 & 0 & 29 & 667 \\
\hline G & N.Kalmarsund & 2 & 16 & 0 & 14 & 50 & 30 & 170 & 323 \\
\hline $\mathrm{H}$ & H skärgård & 0 & 0 & 0 & & & & & 10 \\
\hline K & Öland & 2 & 2 & 1 & 49 & 37 & 38 & 15 & 149 \\
\hline $\mathrm{L}$ & Gotland & 7 & 13 & 0 & 60 & 102 & 110 & 256 & 869 \\
\hline M & E skärgård & 0 & 0 & 0 & & & & & 72 \\
\hline $\mathrm{N}$ & D skärgård & 0 & 0 & 16 & & & & & 7 \\
\hline \multirow[t]{2}{*}{$\mathrm{O}$} & B skärgård & 0 & 0 & 0 & & & & & 256 \\
\hline & Total & 348 & & & & & & & 3716 \\
\hline
\end{tabular}


Appendix 1, continued.

Shelduck Tadorna tadorna

\begin{tabular}{|c|c|c|c|c|c|c|c|c|c|}
\hline & Region & 1971 & 1972 & 1973 & 1987 & 1988 & 1989 & 1993 & 2004 \\
\hline V & Bohuslän & 0 & & & 0 & 5 & 1 & & 10 \\
\hline A & N.Halland & 0 & 0 & & 0 & 0 & 17 & & 0 \\
\hline B & Varberg-Kullen & 0 & 0 & 2 & 0 & 2 & 88 & & 0 \\
\hline $\mathrm{C}$ & Öresund & 1 & 0 & 14 & 0 & 9 & 68 & 192 & 6 \\
\hline D & Falsterbo-Hanö & 1 & 0 & 0 & 0 & 0 & 13 & 20 & 1 \\
\hline $\mathrm{E}$ & Blekinge skärg. & 0 & 0 & 0 & 0 & 0 & 1 & 1 & 1 \\
\hline $\mathrm{F}$ & S.Kalmarsund & 0 & 0 & 0 & 0 & 0 & 1 & 0 & 0 \\
\hline G & N.Kalmarsund & 0 & 0 & 0 & 0 & 0 & 0 & 0 & 0 \\
\hline $\mathrm{H}$ & H skärgård & 0 & 0 & 0 & & & & & 0 \\
\hline K & Öland & 0 & 1 & 3 & 0 & 0 & 2 & 3 & 2 \\
\hline $\mathrm{L}$ & Gotland & 0 & 0 & 0 & 0 & 0 & 0 & 12 & 0 \\
\hline $\mathrm{M}$ & E skärgård & 0 & 0 & 0 & & & & & 0 \\
\hline $\mathrm{N}$ & D skärgård & 0 & 0 & 0 & & & & & 0 \\
\hline $\mathrm{O}$ & B skärgård & 0 & 0 & 0 & & & & & 0 \\
\hline & Total & 2 & & & & & & & 20 \\
\hline
\end{tabular}

Mute Swan Cygnus olor

\begin{tabular}{|c|c|c|c|c|c|c|c|c|c|}
\hline & Region & 1971 & 1972 & 1973 & 1987 & 1988 & 1989 & 1993 & 2004 \\
\hline V & Bohuslän & 1007 & & & 1393 & 1680 & 913 & & 3287 \\
\hline A & N.Halland & 390 & 500 & & 149 & 679 & 256 & & 467 \\
\hline B & Varberg-Kullen & 360 & 210 & 540 & 305 & 286 & 180 & & 341 \\
\hline $\mathrm{C}$ & Öresund & 2020 & 2160 & 2170 & 2460 & 3120 & 3080 & 2708 & 3831 \\
\hline $\mathrm{D}$ & Falsterbo-Hanö & 320 & 240 & 440 & 1312 & 465 & 809 & 882 & 1109 \\
\hline $\mathrm{E}$ & Blekinge skärg. & 540 & 510 & 740 & 634 & 560 & 712 & 1251 & 2773 \\
\hline $\mathrm{F}$ & S.Kalmarsund & 270 & 200 & 420 & 267 & 191 & 262 & 1234 & 1311 \\
\hline G & N.Kalmarsund & 77 & 160 & 190 & 285 & 323 & 186 & 1467 & 1309 \\
\hline $\mathrm{H}$ & H skärgård & 42 & 110 & 160 & & & & & 1358 \\
\hline K & Öland & 380 & 540 & 810 & 737 & 670 & 792 & 2137 & 1981 \\
\hline $\mathrm{L}$ & Gotland & 440 & 590 & 460 & 1817 & 1550 & 2403 & 3393 & 8145 \\
\hline M & E skärgård & 14 & 41 & 250 & & & & & 1150 \\
\hline $\mathrm{N}$ & D skärgård & 71 & 53 & 222 & & & & & 789 \\
\hline $\mathrm{O}$ & $\mathrm{B}$ skärgård & 1350 & 1020 & 1100 & & & & & 3287 \\
\hline & Total & 7281 & & & & & & & 31138 \\
\hline
\end{tabular}

Whooper Swan Cygnus cygnus

\begin{tabular}{|c|c|c|c|c|c|c|c|c|c|}
\hline & Region & 1971 & 1972 & 1973 & 1987 & 1988 & 1989 & 1993 & 2004 \\
\hline V & Bohuslän & 167 & & & 709 & 374 & 230 & & 316 \\
\hline A & N.Halland & 0 & 25 & & 29 & 86 & 5 & & 34 \\
\hline B & Varberg-Kullen & 170 & 100 & 110 & 18 & 73 & 89 & & 139 \\
\hline $\mathrm{C}$ & Öresund & 580 & 320 & 320 & 509 & 25 & 6 & 21 & 60 \\
\hline $\mathrm{D}$ & Falsterbo-Hanö & 87 & 110 & 100 & 175 & 53 & 215 & 47 & 181 \\
\hline $\mathrm{E}$ & Blekinge skärg. & 28 & 0 & 15 & 130 & 47 & 27 & 86 & 250 \\
\hline $\mathrm{F}$ & S.Kalmarsund & 2 & 0 & 4 & 1 & 17 & 3 & 12 & 134 \\
\hline G & N.Kalmarsund & 0 & 2 & 0 & 0 & 0 & 0 & 0 & 3 \\
\hline $\mathrm{H}$ & H skärgård & 0 & 0 & 0 & & & & & 0 \\
\hline $\mathrm{L}$ & Gotland & 380 & 370 & 310 & 142 & 199 & 127 & 250 & 317 \\
\hline M & E skärgård & 0 & 2 & 0 & & & & & 0 \\
\hline $\mathrm{N}$ & D skärgård & 0 & 17 & 6 & & & & & 0 \\
\hline $\mathrm{O}$ & B skärgård & 20 & & 13 & & & & & 51 \\
\hline & Total & 1434 & & & & & & & 1485 \\
\hline
\end{tabular}


Appendix 1, continued.

Coot Fulica atra

\begin{tabular}{|c|c|c|c|c|c|c|c|c|c|}
\hline & Region & 1971 & 1972 & 1973 & 1987 & 1988 & 1989 & 1993 & 2004 \\
\hline V & Bohuslän & 40 & & & 3 & 1 & 0 & & 235 \\
\hline A & N.Halland & 0 & 590 & & 6 & 0 & 14 & & 238 \\
\hline B & Varberg-Kullen & 230 & 360 & 420 & 3 & 4 & 10 & & 50 \\
\hline $\mathrm{C}$ & Öresund & 2410 & 3320 & 4290 & 1205 & 643 & 278 & 2094 & 4714 \\
\hline $\mathrm{D}$ & Falsterbo-Hanö & 140 & 1160 & 1140 & 35 & 414 & 630 & 784 & 3406 \\
\hline E & Blekinge skärg. & 490 & 1120 & 1760 & 272 & 521 & 372 & 3054 & 4108 \\
\hline $\mathrm{F}$ & S.Kalmarsund & 70 & 2 & 780 & 2 & 23 & 0 & 554 & 740 \\
\hline G & N.Kalmarsund & 70 & 12 & 260 & 20 & 52 & 15 & 100 & 349 \\
\hline $\mathrm{H}$ & H.skärgård & 110 & 740 & 1450 & & & & & 0 \\
\hline K & Öland & 30 & 20 & 160 & 0 & 1 & 0 & 0 & 167 \\
\hline $\mathrm{L}$ & Gotland & 260 & 270 & 520 & 173 & 232 & 255 & 1707 & 938 \\
\hline M & E skärgård & 0 & 0 & 280 & & & & & 0 \\
\hline $\mathrm{N}$ & D skärgård & 10 & 280 & 1770 & & & & & 122 \\
\hline $\mathrm{O}$ & B skärgård & & & 1450 & & & & & 530 \\
\hline & Total & 3860 & & & & & & & 15597 \\
\hline
\end{tabular}

Black-throated Diver Gavia arctica

\begin{tabular}{|c|c|c|c|c|c|c|c|c|c|}
\hline & Region & 1971 & 1972 & 1973 & 1987 & 1988 & 1989 & 1993 & 2004 \\
\hline V & Bohuslän & & & & 0 & 28 & 5 & & 2 \\
\hline A & N.Halland & & 0 & & 0 & 4 & 0 & & 0 \\
\hline B & Varberg-Kullen & & 0 & 0 & 1 & 15 & 2 & & 56 \\
\hline $\mathrm{C}$ & Öresund & & 0 & 0 & 0 & 0 & 0 & 1 & 2 \\
\hline D & Falsterbo-Hanö & & 0 & 0 & 0 & 0 & 0 & 0 & 10 \\
\hline $\mathrm{E}$ & Blekinge skärg. & & 0 & 0 & 0 & 2 & 2 & 0 & 1 \\
\hline $\mathrm{F}$ & S.Kalmarsund & & 0 & 0 & 0 & 3 & 3 & 1 & 0 \\
\hline G & N.Kalmarsund & & 0 & 0 & 0 & 3 & 0 & 1 & 1 \\
\hline $\mathrm{H}$ & H.skärgård & & 0 & 0 & & & & & 1 \\
\hline K & Öland & & 1 & 0 & 0 & 3 & 0 & 4 & 11 \\
\hline $\mathrm{L}$ & Gotland & & 0 & 1 & 1 & 26 & 3 & 33 & 30 \\
\hline M & E skärgård & & 0 & 0 & & & & & 0 \\
\hline $\mathrm{N}$ & D skärgård & & 0 & 0 & & & & & 0 \\
\hline $\mathrm{O}$ & B skärgård & & 0 & 1 & & & & & 0 \\
\hline & Total & & & & & & & & 114 \\
\hline
\end{tabular}

Red-throated Diver Gavia stellata

\begin{tabular}{|c|c|c|c|c|c|c|c|c|c|}
\hline & Region & 1971 & 1972 & 1973 & 1987 & 1988 & 1989 & 1993 & 2004 \\
\hline V & Bohuslän & & & & 0 & 4 & 1 & & 0 \\
\hline A & N.Halland & & 0 & & 0 & 16 & 1 & & 14 \\
\hline B & Varberg-Kullen & & 0 & 1 & 0 & 184 & 56 & & 0 \\
\hline $\mathrm{C}$ & Öresund & & 1 & 0 & 0 & 0 & 1 & 8 & 0 \\
\hline D & Falsterbo-Hanö & & 1 & 1 & 0 & 4 & 3 & & 0 \\
\hline $\mathrm{E}$ & Blekinge skärg. & & 0 & 0 & 0 & 0 & 5 & & 1 \\
\hline $\mathrm{F}$ & S.Kalmarsund & & 0 & 0 & 0 & 6 & 7 & & 0 \\
\hline G & N.Kalmarsund & & 0 & 0 & 0 & & 0 & & 1 \\
\hline $\mathrm{H}$ & H.skärgård & & 0 & 0 & & & & & 0 \\
\hline $\mathrm{K}$ & Öland & & 0 & 0 & 0 & 2 & 4 & 35 & 2 \\
\hline $\mathrm{L}$ & Gotland & & 0 & 0 & 1 & 16 & 15 & 24 & 10 \\
\hline M & E skärgård & & 0 & 0 & & & & & 0 \\
\hline $\mathrm{N}$ & D skärgård & & 0 & 0 & & & & & 0 \\
\hline $\mathrm{O}$ & B skärgård & & 2 & 1 & & & & & 2 \\
\hline & Total & & & & & & & & 30 \\
\hline
\end{tabular}


Appendix 1, continued.

Great-crested Grebe Podiceps cristatus

\begin{tabular}{|c|c|c|c|c|c|c|c|c|c|}
\hline & Region & 1971 & 1972 & 1973 & 1987 & 1988 & 1989 & 1993 & 2004 \\
\hline V & Bohuslän & 0 & & & 0 & 2 & 0 & & 2 \\
\hline A & N.Halland & 0 & 0 & & 0 & 7 & 0 & & 2 \\
\hline B & Varberg-Kullen & 4 & 0 & 1 & 4 & 22 & 5 & & 48 \\
\hline $\mathrm{C}$ & Öresund & 1 & 3 & 0 & 51 & 36 & 2 & 25 & 3116 \\
\hline D & Falsterbo-Hanö & 0 & 1 & 0 & 0 & 5 & 0 & 40 & 391 \\
\hline $\mathrm{E}$ & Blekinge skärg. & 0 & 0 & 0 & 0 & 5 & 22 & 118 & 438 \\
\hline $\mathrm{F}$ & S.Kalmarsund & 0 & 0 & 0 & 0 & 1 & 0 & 2 & 1 \\
\hline G & N.Kalmarsund & 0 & 1 & 0 & 1 & 4 & 2 & 2 & 46 \\
\hline $\mathrm{H}$ & H.skärgård & 0 & 0 & 0 & & & & & 7 \\
\hline K & Öland & 0 & 0 & 0 & 0 & 7 & 12 & 2 & 8 \\
\hline $\mathrm{L}$ & Gotland & 10 & 4 & 5 & 1 & 3 & 10 & 62 & 230 \\
\hline M & E skärgård & 0 & 0 & 0 & & & & & 0 \\
\hline $\mathrm{N}$ & D skärgård & 0 & 0 & 1 & & & & & 0 \\
\hline \multirow[t]{2}{*}{$\mathrm{O}$} & B skärgård & 0 & 0 & 3 & & & & & 5 \\
\hline & Total & 15 & & & & & & & 4294 \\
\hline
\end{tabular}

Red-necked Grebe Podiceps griseigena

\begin{tabular}{|c|c|c|c|c|c|c|c|c|c|}
\hline & Region & 1971 & 1972 & 1973 & 1987 & 1988 & 1989 & 1993 & 2004 \\
\hline V & Bohuslän & 0 & & & 0 & 0 & 0 & & 2 \\
\hline A & N.Halland & 0 & 0 & & 1 & 0 & 0 & & 0 \\
\hline B & Varberg-Kullen & 1 & 0 & 0 & 0 & 4 & 0 & & 0 \\
\hline $\mathrm{C}$ & Öresund & 0 & 0 & 0 & 3 & 0 & 0 & 0 & 0 \\
\hline $\mathrm{D}$ & Falsterbo-Hanö & 0 & 0 & 0 & 0 & 2 & 2 & 1 & 1 \\
\hline $\mathrm{E}$ & Blekinge skärg. & 0 & 0 & 0 & 1 & 0 & 0 & 0 & 1 \\
\hline $\mathrm{F}$ & S.Kalmarsund & 0 & 0 & 0 & 0 & 0 & 0 & 1 & 0 \\
\hline G & N.Kalmarsund & 0 & 0 & 0 & 0 & 0 & 0 & 0 & 1 \\
\hline $\mathrm{H}$ & H.skärgård & 0 & 0 & 0 & & & & & 0 \\
\hline K & Öland & 0 & 0 & 0 & 0 & 2 & 0 & 1 & 19 \\
\hline $\mathrm{L}$ & Gotland & 2 & 0 & 0 & 0 & 3 & 7 & 2 & 11 \\
\hline M & E skärgård & 0 & 0 & 0 & & & & & 0 \\
\hline $\mathrm{N}$ & D skärgård & 0 & 0 & 0 & & & & & 0 \\
\hline $\mathrm{O}$ & B skärgård & 0 & 0 & 2 & & & & & 0 \\
\hline & Total & 3 & & & & & & & 35 \\
\hline
\end{tabular}

\section{Slavonian Grebe Podiceps auritus}

\begin{tabular}{|c|c|c|c|c|c|c|c|c|c|}
\hline & Region & 1971 & 1972 & 1973 & 1987 & 1988 & 1989 & 1993 & 2004 \\
\hline V & Bohuslän & & & & 0 & 0 & 0 & & 5 \\
\hline A & N.Halland & & 0 & & 0 & 1 & 0 & & 0 \\
\hline B & Varberg-Kullen & & 0 & 3 & 0 & 1 & 1 & & 33 \\
\hline $\mathrm{C}$ & Öresund & & 0 & 0 & 0 & 0 & 0 & 1 & 0 \\
\hline D & Falsterbo-Hanö & & 0 & 0 & 0 & 0 & 0 & 0 & 16 \\
\hline $\mathrm{E}$ & Blekinge skärg. & & 0 & 0 & 0 & 0 & 0 & 0 & 2 \\
\hline $\mathrm{F}$ & S.Kalmarsund & & 0 & 0 & 0 & 0 & 0 & 0 & 0 \\
\hline G & N.Kalmarsund & & 0 & 0 & 0 & 0 & 0 & 2 & 0 \\
\hline $\mathrm{H}$ & H.skärgård & & 0 & 0 & & & & & 0 \\
\hline K & Öland & & 0 & 0 & 0 & 0 & 0 & 0 & 0 \\
\hline $\mathrm{L}$ & Gotland & & 2 & 0 & 0 & 1 & 0 & 1 & 19 \\
\hline $\mathrm{M}$ & E skärgård & & 0 & 0 & & & & & 0 \\
\hline $\mathrm{N}$ & D skärgård & & 0 & 0 & & & & & 0 \\
\hline $\mathrm{O}$ & B skärgård & & 0 & 0 & & & & & 0 \\
\hline & Total & & & & & & & & 75 \\
\hline
\end{tabular}


Appendix 1, continued.

Little grebe Tachybaptus ruficollis

\begin{tabular}{|c|c|c|c|c|c|c|c|c|c|}
\hline & Region & 1971 & 1972 & 1973 & 1987 & 1988 & 1989 & 1993 & 2004 \\
\hline V & Bohuslän & & & & 0 & 0 & 2 & & 17 \\
\hline A & N.Halland & & 0 & & 0 & 0 & 0 & & 0 \\
\hline B & Varberg-Kullen & & 0 & 0 & 1 & 0 & 0 & & 3 \\
\hline $\mathrm{C}$ & Öresund & & 0 & 0 & 0 & 0 & 4 & 19 & 33 \\
\hline D & Falsterbo-Hanö & & 0 & 0 & 0 & 0 & 0 & 0 & 26 \\
\hline $\mathrm{E}$ & Blekinge skärg. & & 0 & 0 & 0 & 0 & 0 & 4 & 3 \\
\hline $\mathrm{F}$ & S.Kalmarsund & & 0 & 0 & 0 & 0 & 0 & 0 & 3 \\
\hline G & N.Kalmarsund & & 0 & 0 & 0 & 0 & 0 & 0 & 4 \\
\hline $\mathrm{H}$ & H.skärgård & & 0 & 0 & & & & & 0 \\
\hline $\mathrm{K}$ & Öland & & 0 & 0 & 0 & 0 & 0 & 0 & 0 \\
\hline $\mathrm{L}$ & Gotland & & 0 & 0 & 0 & 1 & 0 & 2 & 4 \\
\hline $\mathrm{M}$ & E skärgård & & 0 & 0 & & & & & 0 \\
\hline $\mathrm{N}$ & D skärgård & & 0 & 0 & & & & & 0 \\
\hline $\mathrm{O}$ & B skärgård & & 1 & 0 & & & & & 2 \\
\hline & Total & & & & & & & & 95 \\
\hline
\end{tabular}

\section{Heron Ardea cinerea}

\begin{tabular}{|c|c|c|c|c|c|c|c|c|c|}
\hline & Region & 1971 & 1972 & 1973 & 1987 & 1988 & 1989 & 1993 & 2004 \\
\hline V & Bohuslän & & & & 0 & 19 & 121 & & 99 \\
\hline A & N.Halland & & 9 & & 1 & 30 & 20 & & 0 \\
\hline B & Varberg-Kullen & & 0 & 22 & 0 & 13 & 17 & & 39 \\
\hline $\mathrm{C}$ & Öresund & & 0 & 9 & 0 & 15 & 15 & 17 & 40 \\
\hline D & Falsterbo-Hanö & & 13 & 1 & 17 & 12 & 25 & 53 & 60 \\
\hline $\mathrm{E}$ & Blekinge skärg. & & 0 & 1 & 0 & 27 & 6 & 38 & 45 \\
\hline $\mathrm{F}$ & S.Kalmarsund & & 0 & 1 & 0 & 0 & 0 & 56 & 25 \\
\hline G & N.Kalmarsund & & 0 & 0 & 4 & 1 & 3 & 27 & 28 \\
\hline $\mathrm{H}$ & H.skärgård & & 0 & 0 & & & & & 0 \\
\hline $\mathrm{K}$ & Öland & & 2 & 0 & 0 & 0 & 0 & 17 & 21 \\
\hline L & Gotland & & 0 & 0 & 0 & 7 & 6 & 136 & 134 \\
\hline M & E skärgård & & 0 & 0 & & & & & 0 \\
\hline $\mathrm{N}$ & D skärgård & & 1 & 0 & & & & & 1 \\
\hline $\mathrm{O}$ & B skärgård & & 0 & 1 & & & & & 3 \\
\hline & Total & & & & & & & & 495 \\
\hline
\end{tabular}

Cormorant Phalacrocorax carbo

\begin{tabular}{|c|c|c|c|c|c|c|c|c|c|}
\hline & Region & 1971 & 1972 & 1973 & 1987 & 1988 & 1989 & 1993 & 2004 \\
\hline V & Bohuslän & 172 & & & 1503 & 1601 & 652 & & 3438 \\
\hline A & N.Halland & 113 & 171 & & 199 & 675 & 189 & & 806 \\
\hline B & Varberg-Kullen & 200 & 600 & 310 & 749 & 1452 & 891 & & 1346 \\
\hline $\mathrm{C}$ & Öresund & 8 & 3 & 19 & 39 & 71 & 171 & 1507 & 1480 \\
\hline $\mathrm{D}$ & Falsterbo-Hanö & 1 & 2 & 1 & 53 & 43 & 61 & 570 & 476 \\
\hline E & Blekinge skärg. & 163 & 72 & 122 & 27 & 185 & 95 & 1190 & 836 \\
\hline $\mathrm{F}$ & S.Kalmarsund & 0 & 0 & 0 & 3 & 10 & 0 & 109 & 18 \\
\hline G & N.Kalmarsund & 0 & 0 & 0 & 88 & 0 & 10 & 0 & 185 \\
\hline $\mathrm{H}$ & H.skärgård & 11 & 0 & 3 & & & & & 300 \\
\hline K & Öland & 3 & 0 & 0 & 58 & 2 & 0 & 0 & 279 \\
\hline $\mathrm{L}$ & Gotland & 143 & 135 & 111 & 339 & 580 & 501 & 1277 & 1028 \\
\hline M & E skärgård & 124 & 566 & 170 & & & & & 209 \\
\hline $\mathrm{N}$ & D skärgård & 40 & 20 & 100 & & & & & 162 \\
\hline $\mathrm{O}$ & B skärgård & 30 & 150 & 203 & & & & & 1146 \\
\hline & Total & 1008 & & & & & & & 11709 \\
\hline
\end{tabular}


Appendix 2. Published reports from the Waterfowl Counts in Sweden.

Nilsson, L. 1962. Från andräkningarna 1959/60 och 1960/61: Gräsanden (Anas platyrhynchos) och viggen (Aythya fulgula). Vår Fågelvärld 21: 121-129.

Nilsson, L. 1964. En räkning av de övervintrande andfåglarna efter Skånekusten 2.2.64. Meddelanden från SkOF 3: 38-39.

Nilsson, L. 1965 Andfåelräkningar efter Skånes kuster 1964/65. Meddelanden från SkOF 4: 46-50.

Nilsson, L. 1967. Könsfördelningen hos övervintrande gräsänder i Sverige - en kommentar. Vår Fågelvärld 26: 376-379.

Nilsson, L. 1967. Midvinterräkningar av änder och annan sjöfågel längs den svenska kusten 1964-1966. Vår Fågelvärld 26: 37-53.

Nilsson, L. 1967. Knipans vinterutbredning, flyttning och könskvot i Sverige. Fauna och Flora 62: 75-99.

Nilsson, L. 1967. Midvinterräkning av svenska andfåglar. Sveriges Natur 58: 242-244.

Nilsson, L. 1967. Internationellt samarbete inom andfågelforskningen. Jakt och Jägare 27: 36-40.

Nilsson, L. 1968. Seasonal Fluctuations in Numbers of Swedish Winter Ducks. Vår Fågelvärld 27: 142-171.

Nilsson, L. 1968. Internationella midvinterinventeringarna av änder och svanar i Sverige 1967 och 1968. Vår Fågelvärld 27: 333-344.

Nilsson, L. 1969. The migration of the goldeneye in NW Europe. Wildfowl 20: 112-118

Nilsson, L. 1970. Andfågelräkningarna i Sverige i januari 1969 och 1970 samt november 1969. Vår Fågelvärld 29: 149-159.

Nilsson, L. 1970. Sjöfåglar i Malmöområdet vintrarna 1965/66-1969/70. Fauna och Flora 65: 215-224.

Nilsson, L. 1970. Local and Seasonal Variation in Sex-Ratios of Diving Ducks in South Sweden. Ornis Scandinavica 1: 115-128.

Nilsson, L. 1972. Novemberinventeringar av skånska sjöfåglar 1969-71. Meddelanden från SkOF 11: 12-15.

Nilsson, L. 1972. Söfågelinventeringar i Blekinge under vinterhalvåren 1969-1971. Blekinges Natur 3: 116128.

Nilsson, L. 1973. Internationella sjöfågelinventeringarna i Sverige vintrarna 1970/71 och 1971/72. Vår Fågelvärld 32: 269-281.

Nilsson, L. 1974. Tio års midvinterinventeringar av skånska andfåglar. Anser 13: 65-70.

Nilsson, L. 1974. Annual Fluctuations Among Swedish Mallards (Anas platyrhynchos) and Their Possible Causes. Proc. Int. Congr. Game Biol. 11: 245-248.

Nilsson, L. 1974. Rastande och övervintrande sjöfågel i Ringsjön 1968-1974. Anser 13: 201-210.

Nilsson, L. 1975. Midwinter distribution and numbers of Swedish Anatidae. Ornis Scandinavica 6: 83-107.

Nilsson, L. 1975.Inventeringar av rastande och övervintrande sjöfåglar i sydvästra Skåne 1961-1975. Anser 14: 93-108, 165-178, 225-236.

Nilsson, L. 1975. Internationella midinterinventeringarna av andfåglar. Viltnytt 3(1975): 1-15.

Nilsson, L. 1976.. Andfåglarnas säsongsmässiga uppträdande i södra Sverige under icke häckningstid. Vår Fågelvärld 35: 8-20.

Nilsson, L. 1976. Internationellt betydelsefulla rast och övervintringslokaler för andfåglar i södra Sverige. Vår Fågelvärld 35: 130-136.

Nilsson, L. 1976. Några sjöfågelarters uppträdande i södra Sverige under vinterhalvåret. Fauna och Flora 71: 216-229.

Nilsson, L. 1976. Monthly counts as a measure of population changes in some species of Anatidae in south Sweden. Ornis Scandinavica 7: 193-205.

Nilsson, L. 1976. Sex-ratios of Swedish Mallard during the non-breeding season. Wildfowl 27: 91-94.

Nilsson, L. 1977. Midvinterinventeringar av änder, svanar och sothöns utmed den skånska kusten 1967-1976. Anser 16: 27-36.

Nilsson, L. 1977. Novemberutbredning av änder, svanar och sothöns utmed den skånska kusten 1969-1973. Anser 16: 217-224.

Nilsson, L. 1977. November distribution and numbers of Swedish Anatidae. Viltrevy 10(1977): 41-77.

Nilsson, L. 1977. Andfåglarna - en internationell naturresurs. Sveriges Natur årsbok 1977:285-291.

Nilsson, L. 1977. Rastande änder och svanar i några skånska sjöar 1961-1975. Anser 16:247-254.

Nilsson, L. 1977. Rast och övervintringslokaler för änder, svanar och sothöns i södra Sverige. SNV PM 914: $1-72$.

Nilsson, L. 1978. Internationella sjöfågelinventeringarna i Sverige 1972/73-1975/76. Vår Fågelvärld 37: 1932. 
Nilsson, L. 1978. Andfåglar - internationellt vilt. Jaktsignalen 35: 10-14.

Nilsson, L. 1978. Internationella sjöfågelinventeringarna i Sverige 1976-77. Vår Fågelvärld 37: 121-126.

Nilsson, L. 1978. Sjöfågelinventeringar mellan Roneby och Karlskrona 1970/71-1974/75. Blekinges Natur 10:171-184.

Nilsson, L. 1978. Internationella sjöfågelinventeringarna i Sverige 1977-1978. Vår Fågelvärld 37: 319-324.

Nilsson, L. 1979. Tio års midvinterinventeringar av andfåglar och sothöns i Blekinge 1969-1978. Blekinges Natur 11:181-199.

Nilsson, L. 1979. Midvinterinventeringar av änder, svanar och sothöns runt Öland 1969-1978. Calidris 8: 87102.

Nilsson, L. 1979. Variation in the production of young in swans wintering in Sweden. Wildfowl 30: 129-134.

Nilsson, L. 1979. Internationella sjöfågelinventeringarna i Sverige 1978-1979. Vår Fågelvärld 38: 281-285.

Nilsson, L. 1980. De övervintrande alfåglarnas Clangula hyemalis antal och utbredning längs den svenska kusten. Vår Fågelvärld 39: 1-14.

Nilsson, L. 1980. Wintering diving duck populations and available food resources in the Baltic. Wildfowl 31:131-143.

Nilsson, L. 1980. Utbredning i mars av änder, svanar och sothöns utmed den skånska kusten 1966 samt 19761979. Anser 19: 11-18.

Nilsson, L. 1980. Marsinventeringar av änder, svanar och vissa andra sjöfåglar i södra Sverige 1976-1979. Vår Fågelvärld 39: 149-160.

Nilsson, L. 1980. Internationella sjöfågelinventeringarna i Sverige 1979-1980. Vår Fågelvärld 39: 251-254.

Nilsson, L. 1980. Änders, svanars och vissa andra sjöfåglars utbredning och antal i september i södra Sverige. Vår Fågelvärld 39: 277-290.

Nilsson, L. 1980. Flyttning och övervintring hos svenska storskarvar Phalacrocorax carbo. Fauna och Flora 75 : 209-216.

Nilsson, L. 1981. Internationella sjöfågelinventeringarna i Sverige 1980-81. Vår Fågelvärld 40: 270-272.

Nilsson, L. 1982. Situationen för övervintrande sjöfåglar längs den svenska Östersjökusten. Viltrapport 21): 11-16. Trondheim

Nilsson, L. 1982. Tobisgrisslans Cepphus grylle vinterutbredning utmed den svenska ostkusten. Anser 21: 8992.

Nilsson, L. 1982. Internationella sjöfågelinventeringarna i Sverige 1981-82. Vår Fågelvärld 41: 345-347.

Nilsson, L. 1982. Vinteränder i södra Halland. Fåglar på Västkusten 16: 89-98.

Nilsson, L. 1983. Internationella sjöfågelinventeringarna i Sverige 1982-83. Vår Fågelvärld 42: 253-255.

Nilsson, L. 1983. Midvinterinventeringar av sjöfågel utmed Skånes kuster 1964-1983. Anser 22: 129-140.

Nilsson, L. 1983. Septemberinventeringar av änder, svanar och vissa andra sjöfåglar utmed Skånes västkust 1962-1982. Anser 22: 231-238.

Nilsson, L. 1983. September and January counts as a measure of changes in south Swedish Mallard populations. Wildfowl 34: 89-98.

Nilsson, L. 1984. Årliga fluktuationer och långtidsförändringar i antalet övervintrande sjöfåglar i södra Sverige. Vår Fågelvärld 43: 95-106.

Nilsson, L. 1984. Fluktuationer och trender i antalet rastande sjöfåglar i södra Sverige i september 1973-1982. Vår Fågelvärld 43: 307-316.

Nilsson, L. 1984. Rika rastplatser viktiga för våra andfåglar. Finlands Natur 43: 14-17.

Nilsson, L. 1984. Internationella sjöfågelinventeringarna i Sverige 1983-84. Vår Fågelvärld 43: 365-367.

Nilsson, L. 1984. The impact of hard winters on waterfowl populations of south Sweden. Wildfowl 35: 71-80.

Nilsson, L. 1985. Internationella sjöfågelinventeringarna i Sverige 1984-85. Vår Fågelvärld 44: 297-300.

Nilsson, L. 1985. Wintering waterfowl off the Baltic coast in Sweden. Comm. Balt. Comm. Study Bird Migr. 17: 45-62.

Nilsson, L. 1986. Internationella sjöfågelinventeringarna i Sverige 1985-86. Vår Fågelvärld 45: 297-300.

Nilsson, L. 1986. Midvinterbestånd och trender i antalet övervintrare av olika andfågelarter i Europa och angränsande områden 1967-1983. Vår Fågelvärld 45: 365-368.

Nilsson, L. 1987. Internationella sjöfågelinventeringarna i Sverige 1986-87. Vår Fågelvärld 46: 279-286.

Nilsson, L. 1988. Internationella sjöfågelinventeringarna i Sverige 1987-88. Vår Fågelvärld 47: 273-279.

Nilsson, L. 1989. Internationella sjöfågelinventeringarna i Sverige 1988-89. Vår Fågelvärld 48: 289-291.

Nilsson, L. 1990. Internationella sjöfågelinventeringarna i Sverige 1989-90. Vår Fågelvärld 49: 297-299.

Nilsson, L. 1990. Midvinterinventeringar av sjöfåglar i Sverige 1987-1989. Naturvårdsverket Rapport 3825: $1-70$. 
Nilsson, L. 1991. Midvinterinventeringar av sjöfåglar i södra Älvsborg 1967-1989. Fåglar i södra Älvsborg 17: $2-9$.

Nilsson, L. 1991. Utbredning, beståndsstorlek samt långtidsförändringar i beståndens storlek hos övervintrande sjöfåglar i Sverige. Ornis Svecica 1:11.28.

Nilsson, L. 1993. Comparision between different methods - Calculation of annual indices from mid-winter counts. IWRB Seaduck Bulletin 3: 12-17.

Nilsson, L. 1994. Midwinter counts of waterfowl along the Baltic coast of Sweden in January 1993. IWRB Seaduck Research Group Bulletin 4:2-7.

Nilsson, L. 1994. Internationella sjöfågelräkningarna i Sverige. Pp. 35-43 in Fågelåret 1993. Sveriges Ornitologiska Förening, Stockholm.

Nilsson, L. 1994. Trettio års midvinterinventeringar av sjöfåglar utmed Skånes kuster, 1964-1993. Anser 33: 245-256.

Nilsson, L. 1995. Internationella andfågelinventeringarna i Skaraborg. Grus 21: 5-10.

Nilsson, L. 1995. Changes in resting and wintering waterfowl populations in Sweden, 1967-1993. The Ring 15: 135-146.

Nilsson, L. 1995. Internationella sjöfågelräkningarna i Sverige. Pp. 37-43 in Fågelåret 1994. Sveriges Ornitologiska Förening, Stockholm.

Nilsson, L. 1996. Internationella sjöfågelräkningarna i Sverige. Pp. 41-47 in Fågelåret 1995. Sveriges Ornitologiska Förening, Stockholm.

Nilsson, L. 1997. New wintering tradition for Wigeon in southernmost Sweden. DSG Bulletin 1:15-17.

Nilsson, L. 1997. Internationella sjöfågelräkningarna i Sverige. Pp. 41-48 in Fågelåret 1996. Sveriges Ornitologiska Förening, Stockholm.

Nilsson, L. 1997. The occurrence of Steller's Eider Polysticta stelleri in Sweden. Wetland International Seaduck Specialist Group Bulletin 7:19-22.

Nilsson, L. 1997. Changes in numbers and habitat utilization of wintering Whooper Swans Cygnus cygnus in Sweden 1964-1997. Ornis Svecica 7: 133-142.

Nilsson, L. 1998. Internationella sjöfågelräkningarna i Sverige. Pp. 43-51 in Fågelåret 1997. Sveriges Ornitologiska Förening, Stockholm.

Nilsson, L. 1999. Internationella sjöfågelräkningarna i Sverige. Pp. 39-46 in Fågelåret 1998. Sveriges Ornitologiska Förening, Stockholm.

Nilsson, L. 2002. Numbers of Mute Swans and Whooper Swans in Sweden, 1967 - 2000. Pp. 53-60 in Proceedings of the Fourth International Swan Symposium, 2001. Waterbirds Special Publication 1 (E.C. Rees, S.L. Earnst \& J. Couldson, eds.)

Nilsson, L. 2005 Wintering swans Cygnus spp. and Coot Fulica atra in the Öresund, South Sweden, in relation to available food resources. Ornis Svecica 15: 13-21.

Nilsson, L. 2005. Long-term trends and changes in numbers and distribution of some wintering waterfowl species along the SwedishBaltic coast. Acta Zoologica Lituanica 15: 151-157.

Nilsson, L. 2005. Forty years of midwinter counts of waterfowl along the coasts of Scania, south Sweden, 1964-2003. Ornis Svecica 15: 127-148.

Nilsson, L. 2006. Midvinterinventeringar av sjöfågel I Stockholms skärgård. Fåglar i Uppland 33(3): 4-14.

Nilsson, L. 2006. 40 års midvinterinventeringar av svenska sjöfåglar. Vår Fågelvärld 65(8): 20-25.

Nilsson, L. 2006. Fluctuations and trends in Swedish waterfowl populations during the last four decades. Pp 478-479 in Waterbirds around the World (G.C. Boere. C.A. Galbraith \& D.A. Stroud, eds.). The Stationary Office. Edinburgh, UK.

Nilsson, L. \& Olsson, M. 2001. Sjöfågelräkningen i Blekinge 1976-2001. Fåglar i Blekinge 37: 37-49. 